\title{
"'The Negro had been run over long enough by white men, and it was time they defend themselves': African-American Mutinies and the Long Emancipation, 1861-1974"
}

Scott F. Thompson

West Virginia University, stthompson@mix.wvu.edu

Follow this and additional works at: https://researchrepository.wvu.edu/etd

Part of the African American Studies Commons, History of Gender Commons, Labor History

Commons, Military History Commons, Social History Commons, and the United States History Commons

\section{Recommended Citation}

Thompson, Scott F., "'"The Negro had been run over long enough by white men, and it was time they defend themselves': African-American Mutinies and the Long Emancipation, 1861-1974"' (2021). Graduate Theses, Dissertations, and Problem Reports. 8051.

https://researchrepository.wvu.edu/etd/8051

This Dissertation is protected by copyright and/or related rights. It has been brought to you by the The Research Repository @ WVU with permission from the rights-holder(s). You are free to use this Dissertation in any way that is permitted by the copyright and related rights legislation that applies to your use. For other uses you must obtain permission from the rights-holder(s) directly, unless additional rights are indicated by a Creative Commons license in the record and/ or on the work itself. This Dissertation has been accepted for inclusion in WVU Graduate Theses, Dissertations, and Problem Reports collection by an authorized administrator of The Research Repository @ WVU.

For more information, please contact researchrepository@mail.wvu.edu. 
"The Negro had been run over long enough by white men, and it was time they defend themselves': African-American Mutinies and the Long Emancipation, 1861-1974"

Scott F. Thompson

Dissertation submitted to the Eberly College of Arts and Sciences at West Virginia University in partial fulfillment of the requirements for the degree of

Doctorate of Philosophy in History

Jason K. Phillips, PhD., Chair Brian P. Luskey, PhD. Kenneth Fones-Wolf, PhD. Barton A. Myers, PhD. Krystal D.F. Akehinmi, PhD.

Department of History

Morgantown, West Virginia 2021

Keywords: emancipation; mutiny; race riot; African American; USCT; Buffalo Soldiers; black sailors; integration; segregation; martial masculinity

Copyright 2021 Scott F. Thompson 


\begin{abstract}
"'The Negro had been run over long enough by white men, and it was time they defend themselves': African-American Mutinies and the Long Emancipation, 1861-1974"
\end{abstract}

\title{
Scott F. Thompson
}

This dissertation analyzes racially motivated mutinies by black military servicemen from the Civil War to the Vietnam War. Resistance against white supremacy in the armed forces illustrates the commitment of generations of African Americans to a vision of freedom centered on bodily, familial, and socioeconomic autonomy. These mutinies thereby warrant the reframing of emancipation as a centuries'-long process rather than a single event confined to the 1860s. Subscribing to martial masculinity, black servicemen believed acting forcefully, and risking their lives or well-being as a result, offered the best path to earning their human rights. AfricanAmerican sailors enjoyed the opportunities offered by the integrated pre-1900 U.S. Navy to such an extent that no unequivocal racially-motivated black naval mutinies exist in the period's historical record. Yet, once the Navy designated separate spaces and roles based on race during the Jim Crow years, ships and ports began producing their own black rebellions. Meanwhile, mutinies and race riots populate the history of African Americans in the U.S. Army. From the time black men started serving in uniform in a permanent capacity, such offenses as unequal compensation, controversial orders, and physical abuse inspired them to revolt. Though black soldiers accused of mutiny generally enjoyed unprecedented legal rights in the second half of the nineteenth century, the Jim Crow era brought a sharp erosion in the government's enforcement of due process rights in court-martial proceedings. Finally, despite civil rights gains during and after World War II, racial tensions remained acute enough to overwhelm the armed forces with mutinous outbreaks into the 1970s. 


\section{Acknowledgments}

While I put in the years of research, writing, and revision, every finished project is ultimately the result of a collaborative effort. The archivists who pulled the records cited throughout this project performed an essential service. I would like to thank the staff of the National Archives, especially those who helped me navigate Record Groups 153 and 125; the Army Heritage and Education Center in Carlisle, Pennsylvania; the Virginia Museum of History and Culture in Richmond; the West Virginia State Archives in Charleston; the Kentucky Historical Society in Frankfort; the Maryland Historical Society in Baltimore; and finally the libraries of the University of Maryland, the University of Kentucky, West Virginia University, and the University of North Carolina-Chapel Hill. Among the highlights of my research trips were friendly archivists, beautiful campuses, the excitement of walking to the archive every morning, and the spiritual connections I felt from handling centuries-old documents.

This project is also indebted to numerous colleagues and friends who provided me with invaluable advice, guidance, and ideas. I felt that I had the best committee for this project. From the project's formative stages to the full defense, Drs. Jason Phillips, Barton Myers, Brian Luskey, Ken Fones-Wolf, and Krystal Akehinmi all pushed the project in fascinating directions based on their respective fields. Brian taught me how to extract deep meanings from black mutineers' words. Ken guided me to the meeting point of labor history and military history. Krystal opened my eyes to the multiple social worlds my subjects inhabited.

What especially made this the best dissertation possible was my luck of having Dr. Jason Phillips as an advisor. I am forever grateful that whenever I stopped into his office or sent him an email, I could always expect him to provide extremely helpful feedback and either offer his own outstanding ideas or refine the rough versions of my own. He showed me what value can result from a Civil War historian transcending that conflict, planting the seeds for expertise in other eras and enabling me to find common threads across time that more temporally focused studies overlook. Some of my clearest arguments and richest analysis bear Dr. Phillips' mark. Ever since I took his research seminar my first semester here at WVU, he has helped me immensely in becoming a better writer. Lessons in prose - aiming for word variety and using the most vivid, descriptive nouns and verbs possible — strengthened this dissertation and will stick with me the rest of my academic career. Under Dr. Phillips' exceptional guidance, I always knew I was in good hands during my time as a PhD student at WVU.

Serving as not just a committee member, but also as my former MA advisor at Texas Tech, Barton has had the longest influence on my development as a scholar. He proved key to my decision on a dissertation topic. While we discussed the mutinous episodes of my Master's thesis, a study of a northern Virginia county's partisan rangers and civilians during the Civil War, he helped me realize the historiographic and storytelling potential of exploring this type of resistance more in depth in a larger work. However strong my definitions of "mutiny" are in this project, they are a function of Barton's decade-long mentorship. The conversations he led in private meetings and in graduate classes about the importance of scholars thoroughly unpacking their terms and concepts have continued to influence me as I sharpen my analytical skills. The ideas he and the rest of the committee provided for this project as it enters the manuscript stage make me excited for what I can submit for publication in the near future. 
Finally, I wish to express an infinite amount of gratitude to those who provided professional and emotional support throughout the research and writing phases of the dissertation, as well as my grad school career in general. Chad Helms and Chuck Welsko especially introduced me to collections and databases that proved to be goldmines for finding mutinies to investigate. Additional conversations with those gentlemen plus many others eased my struggles with how to find the appropriate work-life balance and stay physically and mentally healthy during the $\mathrm{PhD}$ odyssey. These additional individuals include Gabby Aragon, Joel Christenson, Mike Fasulo, Tiffany Gonzalez, Amanda Lancaster, Amber Batura, Luna Helms, Muoki Mbunga, Luke Gramith, Marc Sanko, and Alex Burns.

I am most grateful for the support of my caring family, without whom I would not be here writing this. My mom Janet Thompson, as well as my aunts, uncles, and cousins across the family tree, are my biggest cheerleaders. The only downside to this triumph is that it did not happen in time for my late dad Rod Thompson to see it. However, knowing he would be extremely proud of me earning the "Dr." title kept me going until I reached the finish line.

The resilience and commitment someone needs to finish a dissertation, even under ideal conditions, cannot be overestimated. That this dissertation in particular was written amidst some of the most trying and difficult circumstances of my life makes its completion that much more rewarding and the help I received that much more appreciated. This work is devoted to everyone who has made me a better scholar, historian, and person. 


\section{Table of Contents}

\section{Introduction 1}

1. Masters of the Vessel: African-American Mutinies on the Nineteenth-Century Sea 24

2. "Strong, united, persistent protest": Mutinies of the United States Colored Troops during the Wartime Collapse of Slavery 75

3. "All I want is to get out of the army, or, my rights": African-American Soldier Mutinies in the Immediate Postbellum Era 132

4. "I don't care a damn for you, you take the advantage of me because I am a colored man": Black Soldier Mutinies and Race Riots in the Reconstruction South 191

5. "We will reduce your houses and firesides to ashes and send your guilty souls to hell":

Buffalo Soldier Mutinies from 1867 to 1917236

Conclusion 296

Bibliography 317 


\section{Introduction}

In the fall of 1898, while training at Camp Poland, Tennessee, to fight in the SpanishAmerican War, men of the all-black Sixth Virginia Volunteers mutinied rather than allow the Army to compel them to serve under white officers. As blacks began receiving officer commissions in the late nineteenth-century, African-American soldiers cherished the right to have those of their own race finally command them. Such an arrangement fulfilled a main goal of African Americans who toppled slavery a generation prior: bodily autonomy from white overlords. Initially, black officers led the Sixth Virginia. However, white Colonel Richard Clayborne Croxton, the regiment's commander, wanted to inspect the "fitness, qualification and conduct" of nine black officers on the suspicion that they were delaying the progress of the regiment's training. These men resigned in protest. Among them was Major William H. Johnson, who explained their decision: "knowing that I have no redress from the decision of the (review) board as named; and being persuaded that this order for me means nothing more or less than an outing from the regiment as a Major, I hereby tender my resignation.” The high command replaced the departed with whites. Arguing that the Army had violated an essential term of their enlistment, and feeling insulted at enduring such treatment after they left their jobs and families to answer their country's call to serve, eight hundred enlisted troops refused to drill. As one soldier told a black newspaper, "not a man would move" and they "hooted and hissed" at their new white superiors. The black Virginians added to their rebellious reputation by violating segregation ordnances when their unit subsequently moved to a camp in Georgia. As

punishment, authorities disarmed and arrested the entire "Mutinous Sixth," a nickname its troops 
earned from their resistance to white supremacy. To neutralize this disciplinary problem, the Army simply mustered out the Sixth in January $1899 .^{1}$

When members of the "Mutinous Sixth" chose to defy their commanders and disrupted the regular order of military life, they did not merely express frustration with their superiors' policies and actions in an antagonistic manner. Rather, they fought a single battle in a centuries'long conflict in which uniformed African-American men struggled to expand the degree to which they enjoyed bodily autonomy, family stability, and socioeconomic independence. This set of goals sat at the heart of what bondspeople envisioned when they dreamed of or experienced liberation. Emancipation unfolded as an extensive and convoluted process, with different individuals realizing this vision to varying degrees based on time, location, class, or mere luck. This aspect of emancipation necessitates us to view it as not a single event - the collapse of bondage's final remnants during the Civil War and the social revolution it spawnedbut as a long-term process. It was in the implementation of this "long emancipation" that several generations of blacks serving in the U.S. armed forces — on land and water, stateside and overseas, in peace and war-rebelled against tyrannical white officers and racist white civilians. In framing emancipation in this manner, the dissertation joins a recent trend in the scholarship. The current author's terminology draws from Ira Berlin's 2015 work, The Long

\footnotetext{
1 "Ham" to Richmond Planet, October 15, 1898, in "Smoked Yankees" and the Struggle for Empire: Letters from Negro Soldiers, 1898-1902, Willard B. Gatewood, Jr., ed. (Fayetteville, AR: University of Arkansas Press, 1987), 126-127 (first quote on 126); "Ham" to Richmond Planet, November 5, 1898, in ibid., 131-134 (third quote on 131); "A Black Man" to Richmond Planet, December 10, 1898, in ibid., 140-144; "Ham" to Richmond Planet, December 10, 1898, in ibid., 144-146; "A Black Man" to Richmond Planet, December 24, 1898, in ibid., 146-150; "Ham" to Richmond Planet, December 17, 1898, in ibid., 151-153; "Ham" to Richmond Planet, January 7, 1899, in ibid., 153154; Major Letter from William A. Johnson et. al., November ?, 1898, quoted in Sgt. 1st Class Terra C. Gatti, "Virginia's African American Militiamen: Remembering the 6th Virginia Volunteers," February 20, 2018, https://vaguard.dodlive.mil/2018/02/20/11058/ (second quote). Sixty years after his regiment's mutiny, Sergeant John H. Allen considered himself "lucky" because the actions of him and his comrades neither brought a firing squad nor dishonorable discharges. Quoted in C. G. Krüger and S. Levsen, War Volunteering in Modern Times: From the French Revolution to the Second World War (New York: Palgrave Macmillan, 2010), 103.
} 
Emancipation, which explores the eighty-year struggle to destroy bondage from the American Revolution to the Civil War. Similarly, this dissertation's time period builds on the contributions of the 2016 anthology Rethinking American Emancipation. Beginning where Berlin left off, its authors examine the final abolition of slavery in the 1860s and then connect it to postbellum American society and politics. Racially-motivated mutinies by black servicemen offer a window into the military and social history of the long emancipation studied by the above volumes. Even if slavery as an institution died by 1865 , the emancipation process continued as several generations of African Americans - the formerly enslaved and their descendants-revolted against real and perceived remnants of bondage in the armed forces and in civilian life. ${ }^{2}$

This dissertation formulates a theoretical definition of what constitutes a mutiny and what it means for a particular socioeconomic, political, and/or cultural group to conduct one. Among the various forms of resistance oppressed peoples employ against the sources of their subordination, the mutinous type contains ambiguities, shares parallels with others, and generally lacks a consensus understanding. Historians and contemporaries have devised multiple meanings with varying degrees of utility. The main determiners in shaping how this work defines "mutiny" are how participants and witnesses understood confrontational behavior among servicemen, as well as the effects such conduct had on a military base and its surroundings.

When a serviceman engaged in mutiny, it entailed an aggressive questioning of or refusal to recognize the authority of one's superior officers in order to compel a revision in their unit's

\footnotetext{
${ }^{2}$ Ira Berlin, The Long Emancipation: The Demise of Slavery in the United States (Cambridge and London: Harvard University Press, 2015; William A. Link, "African Americans and the Long Emancipation,"167-186, Paul Ortiz, "Washington, Toussaint, and Bolivar, 'The Glorious Advocates of Liberty': Black Internationalism and Reimagining Emancipation," 187-215, and Laura F. Edwards, "Epilogue: Emancipation and the Nation," 252-269 Rethinking American Emancipation: Legacies of Slavery and the Quest for Black Freedom (Cambridge: Cambridge University Press, 2015). As Edwards accurately notes, wartime abolition was "one among many points in a much longer journey about what America would be without slavery," 252. Also see Patrick Rael, Eighty-Eight Years: The Long Death of Slavery in the United States, 1777-1865 (Athens: University of Georgia Press, 2015).
} 
or military branch's customs, policies, or command decisions. Mutineers belligerently denied the right of their superiors to give certain orders, to direct their men's physical movement, and/or to punish the rank-and-file for crimes. A mutiny exceeded insubordination, disobedience of orders, or an absence without leave, even if many mutineers technically committed at least one of these lesser actions. Rather, a mutiny more deeply tried to subvert the military command structure. Most saw the use of hostile language by the perpetrator(s), including profanity and serious threats. Some mutineers attempted to correct injustices by applying force. Physical actions included freeing an imprisoned comrade or using a weapon on superiors. When in August 1865, enlisted men in the Twelfth U.S. Colored Heavy Artillery fixed bayonets and loaded muskets at their Kentucky fort, the incident, as officers later testified, "cannot be called anything else than a mutiny." Even if a serviceman did not use hostile language or threaten to act violently, the action can still fall within the realm of mutiny if perpetrators disrupted the regular flow of military duty as a means of demanding an improvement in how commissioned officers treated enlisted men. A non-violent form of mutiny entailed soldiers, sailors, or airmen refusing to perform duties, neglecting to man stations, stacking their arms, or organizing unauthorized meetings with comrades. During an 1873 Buffalo Soldier episode in Texas, one participant denied that he was a mutineer because he had been unarmed. Yet, because enlisted men illegally organized and spoke with antagonistic words, white officers and black troops who refused to join the movement alike viewed it as a mutiny because of its levelling nature. Whatever action a mutineer committed, it had the effect of weakening discipline and eroding hierarchy, either concretely or symbolically. Mutinies could be spontaneous or premeditated and involve anywhere from a single individual to numerous personnel. For the sake of prose variety, and to compare mutinies to other types of 
resistance, this dissertation uses the following synonyms: "revolt," "rebellion," "insurrection," and "uprising."

Racially-motivated mutinies by people of African descent warrant their own topic of analysis. To be sure, armed forces throughout world history have their own record of mutinying. Black mutinies, however, possessed an extra layer connected to the history of African-American resistance to white supremacy. This racial element resulted from most black combatants serving under prejudiced white commanders and living in an intolerant society. Black mutineers tended to view injustices as not just a superior's abuse of power, but discrimination. Maltreatments that drove a serviceman to revolt against his commanders - inadequate compensation, physical abuse, unpopular orders, etc. - were that much more threatening to blacks than whites because they too closely resembled the oppression blacks had encountered elsewhere in everyday life.

When they stood as defendants in a court-martial, mutineers were charged with a range of specific offenses. In addition to "mutiny," their commanders could accuse them of disobeying orders, physically attacking a superior, "insubordinate conduct," and "conduct to the prejudice of good order and military discipline." Specifications for these lesser offenses could indicate that the defendant had engaged in "mutinous behavior" or "mutinous conduct," had used "mutinous language," incited mutiny, or had failed to suppress a mutiny. Even if the court never included the word "mutiny" or a derivative thereof, numerous cases document incidents similar in character to those in which court-martial judges and witnesses did speak of a "mutiny" or a "mutinous" affair.

\footnotetext{
${ }^{3}$ Proceedings of a GCM, Trial of Private James Thornton, et. al., August 24-September 17, 1865, RG 153, MM3004, NARA (quote); Nicholas Eskow, "Sympathy for the Loss of a Comrade: Black Citizenship and the 1873 Fort Stockton 'Mutiny,"” UC Berkley, 2018, 28, https://escholarship.org/uc/item/9nf8t9v5.
} 
Defining what constitutes a mutiny becomes a difficult task when one factors in the images people conjure up in their minds. As many still do today, Americans tended to define mutiny exclusively as the revolt of civilian or naval sailors against their captains. Thus, the most common image is the maritime setting. When civilians rebel, observers call the ones on the water "mutinies" while not designating identical land-based actions with the term. This form of mutiny permeates historical fiction. ${ }^{4}$ Yet, most black military mutinies occurred on land.

During the nineteenth century, "mutiny" often meant something other than its literal definition. In their political rhetoric, Americans frequently invoked mutiny in metaphorical terms. People used the ship-based form of mutiny when commenting on intra-political party divisions and the secession crisis. In the summer of 1866, a court opinion reflected on the Civil War, a time when the "ship of state freighted with the hopes of human liberty" was "tossed about upon an angry ocean, its crew in mutiny, its sails gone, and itself a helpless wreck." A "mutiny" could also refer to any popular movement against a government, like the Lincoln administration, or a social institution, like slavery. Also, observers referred to India's 1857 revolt against British colonial rule as the "Indian Mutiny." With Americans equating mutiny with political division and social unrest, we get a sense of why the choice to commit this crime was serious and risky. ${ }^{5}$

\footnotetext{
${ }^{4}$ In a case in point, when the current author informed a graduate student colleague of his dissertation topic in 2015, the latter assumed the former was studying maritime mutinies exclusively. For a literary example, see James Norman Hall and Charles Bernard Nordhoff, Mutiny on the Bounty (Boston, New York, and London: Little, Brown \& Company, 1932).

${ }^{5}$ In the wake of the Democratic Party's sectional splintering during the 1860 election campaign, John J. Crittenden noted at a convention of pro-Stephen Douglas delegates that they, "considered the Breckinridge men as mutineers in the ship of Democracy who should be thrown overboard." In 1870, reflecting on the partisanship of the last decade, the Indianapolis Journal referred to the GOP strategy as throwing a "an unfaithful Jonah" overboard, and the Democracy's plan as one in which the crewmen "get up a mutiny, cut each other's throats, and sink the vessel and her cargo." At least twice in the 1870s, Democratic newspapers described Republican infighting as mutinies. In February 1861, as hostilities approached, Democrats in Franklin County, Pennsylvania, held a convention at Harrisburg. As a tempest rocked the country's "ship of state," the convention's speaker noted, "the crew, whose duty it was, to man the noble vessel, and to steer her clear of the dangers of the deep, has broken into open mutiny, and in their mad efforts to gain the mastery of the ship, have scuttled her and left her to drift at the mercy of the winds and waves." See Staunton Spectator, Volume 37, Number 35, 21 August 1860, https://virginiachronicle.com/cgibin/virginia?a=d\&d=SS18600821.1.2.; Indianapolis Journal, December 2, 1870; "The First Funeral By Fire,"
} 
For literal mutinies, the U.S. armed forces have struggled to settle on a consistent definition. When white Captain Joseph Smoot of the frigate United States faced accusations in 1849 of failing to suppress a mutiny, other officers disagreed whether the incident-a work stoppage for an advance of wages - constituted a mutiny. Some noted that since naval regulations failed to provide a clear definition, captains had the discretion to decide for themselves when their men had crossed into mutinous territory. Others countered that the following definition from a federal court opinion regarding merchant ships applied to naval vessels: "not...simple disobedience of orders, nor...the mere exhibition of turbulence or violence, but...organized and concerted resistance to lawful authority, aiming at the subversion... of the power of those legally entitled to command." Similar to this latter view, in 1896, West Point law professor William Winthrop contended that mere insubordination fell short of a mutiny. To reach that level, belligerents needed to try to "usurp, subvert or override" their superiors' authority as commanding officers. The Winthrop standard formed the basis of the crime's definition in the U.S. Navy's 1937 Naval Courts and Boards, Section 46. The current work finds "usurp, subvert or override" the most useful principle. ${ }^{6}$

Whatever the specific definition, the military branches have always taken the crime of mutiny so seriously that they reserve the worst punishments for it, including death. As the cases

Columbus Daily Enquirer, July 30, 1876; “The Man on Horseback," Princeton Union Democrat, January 29, 1870; "Mutiny in the Republican Camp," Jefferson City Peoples Tribune, July 26, 1876; "Letter from Ohio," Aurora Dearborn Independent, October 30, 1873; Valley Spirit, February 20, 1861, http://valley.lib.virginia.edu/news/vs1861/pa.fr.vs.1861.02.20.xml\#04; Valley Spirit, July 04, 1866, http://valley.lib.virginia.edu/news/vs1866/pa.fr.vs.1866.07.04.xml\#01 (first quote); Staunton Spectator, September 3, 1861, http://valley.lib.virginia.edu/news/ss1861/va.au.ss.1861.09.03.xml\#01 (second quote); James Kennedy, The Great Indian Mutiny of 1857: Its Causes, Features, and Results (London: Ward and Co., 1858); "Additional from Europe the Mutiny in India Important Debates in Parliament the Anglo-African Slave Trade," New York Herald, July 15, 1857, https://infoweb-newsbank-com.www.libproxy.wvu.edu/apps/readex/; "Narrative of William W. Brown," The Liberator, July 30, 1847.

${ }^{6}$ James E. Valle, Rocks \& Shoals: Order and Discipline in the Old Navy, 1800-1861 (Annapolis: Naval Institute Press, 1980), 120-121 (quote); Navy Department, Naval Courts and Boards: 1937: With Table of Corresponding Sections 1937 and 1923 (Washington, D.C.: Government Printing Office, 1944), 14. 
featured in this dissertation reveal, if convicted mutineers avoided execution, they could expect a dishonorable discharge and a period of hard labor. The Army considered mutineers more deserving of capital punishment during times of war and insurrection. Since Florida officially remained in a state of rebellion despite the end of the Civil War several months prior, the Army's justice system chose death for six mutinous USCTs in October 1865. Due to mutiny's place in the range of unlawful behavior, some individual officers decided to quell them outside of the court-martial system, especially in the Navy, where the standard practice was to place offenders in irons, whip them, or informally execute them. One wonders how many African-American military mutinies happened but did not make it into the historical record because superiors informally quelled them, giving writers less motivation to document them. ${ }^{7}$

Scholars have also struggled to narrow or expand the behaviors falling under mutiny. A 1914 work on naval courts-martial referred to events where sailors merely halted their duties as "so-called mutinies [that] were in fact simply strikes"; to be an actual mutiny, the men would have sought to take power of the ship. On the other end of the spectrum are two studies of the topic in a 2001 edited volume that crafted overly broad definitions, classifying Confederate Army deserters and Italian partisans as mutineers. In between these two extremes are Christopher M. Bell and Bruce A. Elleman's definition - "a deliberate act of collective insubordination against lawful naval authority" - and Cornelis J. Lammers' argument that due to shared collective goals—improving interests and acquiring autonomy_-"work stoppage" and "seizure of power" constitute two types of mutiny. Both framings closely match that of the current

\footnotetext{
${ }^{7}$ War Department, Revised United States Army Regulations of 1861 (Washington, D.C.: Government Printing Office, 1863), https://quod.lib.umich.edu/m/moa/AGY4285.0001.001?rgn=main;view=fulltext; Navy Department, Regulations for the Government of the Navy of the United States: 1876 (Washington, D.C.: Government Printing Office, 1877), 173; John F. Fannin, "The Jacksonville Mutiny of 1865," Florida Historical Quarterly Vol. 88 (Winter 2010): 368-396; Cornelius J. Lammers, review of Rebellion, Repression, Reinvention: Mutiny in Comparative Perspective, by Jane Hathaway, International Review of Social History Volume 48, Issue 3 (December 2003), 479.
} 
project. That officers in both the Army and Navy treated work stoppages and violent seizures of power by African-American servicemen with similar levels of seriousness, and that both activities brought the flow of military duties to a halt, suggests that the boundary between "strike" and "mutiny" is a blurred one. Yet, scholars' emphasis on the collective nature of mutinies proves only partly accurate, since servicemen acting individually could also revolt against lawful authority, scaring their superiors into subduing them to prevent the ill-discipline from spreading. The current work disputes naval historian James Valle's assertion that violent, disrespectful behavior from individual enlisted men against their superiors fails to qualify as a "real mutiny" because these actions "threatened their (officers') status and image rather than the actual safety of their ships." While cases fitting Valle's description exist, he paints with too broad a brush. Bloody insubordination by a single soldier or sailor may not have the same tangible effect as a large collection of men trying to seize command over their base, but these former incidents nevertheless represented a challenge to the military command structure. ${ }^{8}$

\footnotetext{
${ }^{8}$ William Winthrop, Military Law and Precedents (BeardBooks: Washington, D.C., 1896); U.S. Navy, Naval Courts and Boards, Section 46, 1937; David Hannay, Naval Courts Martial (Cambridge: Cambridge University Press, 1914), 117 (first quote); Jane Hathaway, ed., Rebellion, Repression, Reinvention: Mutiny in Comparative Perspective (Westport, Connecticut: Praeger Publishers, 2001); Naval Mutinies of the Twentieth Century: An International Perspective, Christopher M. Bell and Bruce A. Elleman, eds. (London and Portland, OR: Frank Cass Publishers, 2003), 1-3 (second quote); Cornelius J. Lammers, "Strikes and Mutinies: Comparative Study of Organizational Conflicts between Rulers and Ruled," Administrative Science Quarterly Vol. 14, No. 4 (Dec., 1969): 562-565 (third quote); James Valle, Rocks and Shoals, 117, 123. For an example of Valle's point, see Records of the Office of the Judge Advocate General (Navy), Court of Inquiry, April 21, 1862, Box 89, file no. 3111, RG 125, National Archives and Record Administration (NARA). A "mutinous riot and affray" occurred on the bark Fernandina off Wilmington, North Carolina, in April 1862, prompting a court of inquiry. The ship's officers tried stopping a crowd of men from loudly and drunkenly "skylarking." One perpetrator told an officer "Browne, you son of a bitch, I will kill you. You are not worthy to wipe my a-se" before attacking him. As the incident escalated, officers received an order to arm themselves because "some of the men were inclined to mutiny." Eventually, an officer "considered the ship to be in a complete state of mutiny." The alleged mutineers included William Hillman (fair complexion, captain of the maintop), John Hillman (dark complexion, from Wellfleet, Massachusetts, enlisted in 1855 at age 22), Michael Heeney (dark complexion but from Ireland or a white New Yorker and captain of the guard), and Charles Mowatt (florid sailor from Baltimore or New York). The last man listed above angrily refused to put irons on Heeney, declaring that such a task was the master-at-arm's job. The court-martial ruled that the events failed to meet mutiny status.
} 
Acts of resistance that only indirectly subverted officers' authority further complicate the task of defining African-American mutinies. Black soldiers performing occupation duties in all eras frequently encountered the second nemesis of the long emancipation: white civilians. When this group made black servicemen feel threatened, abused, or discriminated against, and they felt that their officers failed to adequately protect them from such mistreatment, they resisted through race riots. These armed clashes between stationed black troops and white community members blur with mutinies because they shared the same motivations, tactics, rhetoric, and goals. At times they merged with each other, as exemplified by Houston in 1917.

The author joins the small number of scholars who explore the question of why under certain circumstances, mutinies did not occur. Raymond Callahan argues that despite colonial discrimination and hardship, Indian soldiers during the world wars avoided mutinying because of not only the prospect of independence, but also because mobilization bolstered men's social status and expanded their opportunities. Likewise, the current project explores why no recorded mutinies can be found for certain African-American Army units and numerous generations of the Navy's black personnel. ${ }^{9}$

The personalities, decisions, and surrounding contexts of uniformed African Americans who did mutiny touch on an abundance of topics in social, cultural, political, and military history fields. Among these topics is the masculine side of gender history. The main justifications that USCTs, Buffalo Soldiers, and black sailors gave for their acts of resistance drew on nineteenthcentury notions of masculinity. American men in general linked manhood with someone who defended the honor and well-being of their families and sweethearts. Historians of black Civil War soldiers document how the desire to become and act like a man motivated these troops to

\footnotetext{
${ }^{9}$ Raymond Callahan, "The Indian Army, Total War, and the Dog that Didn't Bark in the Night," in Christopher M. Bell and Bruce A. Elleman, eds., Naval Mutinies of the Twentieth Century, chapter 7.
} 
fight for their and their loved ones' emancipation. By putting on a uniform and thereby

transforming into men, African Americans disproved the white belief that they were perpetual children or subhuman. A source of mutiny was how white officers from the upper and middle class sought to instill refined manners through regulations and courts-martial, which clashed with the rougher masculinity of working-class enlistees. Using the case of Frederick Douglass, who physically brawled with an overseer, A. Kristen Foster examines a martial masculine form of citizenship to which many African Americans in the nineteenth and twentieth centuries subscribed. As Foster shows, after initially promoting a universal citizenship based on natural law, by the late-antebellum period, Douglass contended that African-American men, like he did, needed to commit violence. Doing so would counter a post-revolutionary model of American republican citizenship that excluded them. For Douglass, the black soldier best symbolized republican manhood because he courageously defended the nation and willingly fought for himself, his country, and his family. As Kellie Carter Jackson uncovers, numerous other black abolitionists concluded that violence, not moral suasion, was the most effective method of liberating their people. For servicemen, their choice to mutiny against unfavorable conditions was consistent with trying to remain committed to this masculine ideal. ${ }^{10}$

Observers and scholars sometimes recognize a darker side of martial manhood. Carole Emberton expands on W.E.B. Du Bois' remark in Black Reconstruction that "only murder makes men," referring to the idea that African-American men could only prove themselves worthy of

\footnotetext{
${ }^{10}$ Reid Mitchell, The Vacant Chair: The Northern Soldier Leaves Home (Oxford: Oxford University Press, 1988); Stephen W. Berry, All That Makes a Man: Love and Ambition in the Civil War South (Oxford: Oxford University Press, 2003); Jim Cullen, “'I's a Man Now': Gender and African American Men," in Catherine Clinton and Nina Silber, eds., Divided Houses: Gender and the Civil War (Oxford: Oxford University Press, 1992), 76-91; Lorien Foote, The Gentlemen and the Roughs: Violence, Honor, and Manhood in the Union Army (New York and London: New York University Press, 2010); A. Kristen Foster, “'We Are Men!' Frederick Douglass and the Fault Lines of Gendered Citizenship," Journal of the Civil War Era 1, no. 2 (June 2011):143-175; Kellie Carter Jackson, Force and Freedom: Black Abolitionists and the Politics of Violence (University of Pennsylvania Press, 2019).
} 
freedom and manhood by producing or becoming corpses on the battlefield. Numerous white Americans considered black Civil War soldiers to be an expendable replacement for whites and hoped that military service would discipline, rather than liberate, blacks. The postbellum continuation of this white fixation on black discipline ultimately led to Redemption. Thus, the extolling of violence at the heart of martial manhood ultimately proved fatal to African Americans after slavery. Black mutineers throughout the long emancipation process knew that a tragic fate likely awaited them; the likelihood of a mutiny's success was always marginal, and mutinying nearly guaranteed death or a dishonorable discharge and hard labor. When applying these points to black mutineers, the martial type of manhood pushed servicemen to commit additional actions that threatened their lives, finances, and family welfare. ${ }^{11}$

Black mutinies during the early Jim Crow era complement the existing historiography on how African-American society responded in gendered methods to what is generally considered the nadir of U.S. race relations at the turn of the twentieth century. At a time when black men in the Niagara Movement and NAACP resisted the wave of disenfranchisement, segregation, lynching, and convict leasing, a number of black soldiers rose up against prejudiced officers and hostile civilian communities. Based on their actions and rhetoric, the post-slavery generation in the regular U.S. Army assumed for themselves W.E.B. DuBois' proclamations that "I rejoice as a strong man to run a race" and "We are men; we will be treated as men." When black men invoked martial manhood as their response to the establishment of a new racial caste system, they contrasted with black women who pursued a diplomatic approach to political activism. While responding to new circumstances, Jim Crow-era mutineers compare with their predecessors in the antebellum, Civil War, and Reconstruction periods who believed in the need

\footnotetext{
${ }^{11}$ Carole Emberton, "Only Murder Makes Men”: Reconsidering the Black Military Experience," The Journal of the Civil War Era, Volume 2, Number 3, September 2012, pp. 369-381, 385-388 (quotes).
} 
to forcefully struggle for the rights due them as men: bodily autonomy, family stability, legal and political rights, and socioeconomic independence. ${ }^{12}$

Since some black men during the long emancipation era felt the need to aggressively challenge the authority of abusive or apathetic white officers, African-American mutinies contribute to the scholarship on the relationship between black enlistees and white officers in the Army. This debate colors both USCT and Buffalo Soldier historiography. In his study of the Civil War and its immediate aftermath, Joseph Glatthaar's Forged in Battle paints black soldierwhite officer ties in largely cooperative terms. Glatthaar accurately documents the breakdown of these ties immediately after Union victory, but wartime mutinies display large, preexisting cracks in this relationship. While scholars have always recognized that racial discrimination colored much of the Buffalo Soldier experience, historians like William Dobak and Thomas Phillips contend that regiments occupying the late-nineteenth-century West received equal military resources and duties to that of white units. Carole Emberton focuses on the hostile aspect of the Civil War's white officer-black soldier relationship. As she reveals, white officers often held indifferent and condescending attitudes towards black recruits, who in turn felt pessimistic about each new commander they acquired. ${ }^{13}$ Other historians of the nineteenth-century Army’s race

\footnotetext{
12 W.E.B. DuBois, "Address to the Country," 1906, http://college.cengage.com/history/ayers_primary_sources/niagaramovement_address_1906.htm (first quote); W.E.B. DuBois, "Declaration of Principles,” 1905, https://credo.library.umass.edu/view/pageturn/mums312-b004i092/\#page/1/mode/1up (second quote). As journalist William J. Farris remarked, DuBois' refutation of Washington's ideas "roused the dormant manhood of the Negro." See William H. Ferris, The Africans Abroad, or His Evolution in Western Civilization Tracing His Development under Caucasian Milieu (New Haven: Tuttle, 1913), 403. For an overview of scholarship on black gendered activism at the turn of the century, see Ayumu Kaneko, "A Strong Man to Run a Race: W. E. B. DuBois and the Politics of Black Masculinity at the Turn of the Century," The Japanese Journal of American Studies, No. 14 (2003): 105-122; Matthias Speidel, “A Race That Is Thus Willing To Die For Its Country': African-American Volunteers in the Spanish-American War 1898," in War Volunteering in Modern Times: From the French Revolution to the Second World War (Palgrave Macmillan, 2010), 92-108. For black women's activism during Jim Crow's establishment, see Glenda Gilmore, Gender and Jim Crow: Women and the Politics of White Supremacy in North Carolina, 1896-1920 (Chapel Hill: University of North Carolina Press, 1996).

${ }^{13}$ Joseph T. Glatthaar, Forged in Battle: The Civil War Alliance of Black Soldiers and White Officers (Baton Rouge: Louisiana State University Press, 1990), 11-33, 149, 203-204, 228-229; William A. Dobak and Thomas D. Phillips,
} 
relations have introduced more nuanced interpretations. Keith P. Wilson's study of black Union soldiers' camp lives notes that most USCT officers appreciated black military service, but they tended to focus on their own ambitions. Rather than a sign of emancipation's disappointments, Wilson claims, the Army's discipline merely tried to indiscriminately preserve order. However, the Union Army's preference to assign black troops to fatigue duty taught them that white comrades enjoyed privileged treatment. According to Charles S. Kenner, while the 1860s and 1870s represented a period of inter-rank tensions within the Buffalo Soldier units, relations improved in the 1880s before deteriorating again in the 1890s. Marvin Fletcher argues that particular personalities, locations, and circumstances determined Buffalo Soldier race relations. ${ }^{14}$ Meanwhile, the Navy's white commander-black enlistee relationship depended on the era: until the nineteenth century's end, it represented the sole integrated branch; from the dawn of Jim Crow to the 1970s, it engaged in some form of segregation. Scholars of the nineteenthcentury Navy have consistently noted that no matter how racially restrictive official policy was, officers recruited as many blacks as they could to meet manpower shortages. When officers acted tyrannical and abusive, it grew out of a broader maritime culture based on stringent discipline for all sailors. However, for most of the twentieth century, black sailors felt marginalized by white shipmates and superiors. This dissertation explains what the Navy's unique racial order tells us about the long emancipation process. Given the rarity of racially-

The Black Regulars, 1866-1898 (Norman: University of Oklahoma Press, 2001); Carole Emberton, “Only Murder Makes Men," 371-372.

${ }^{14}$ Keith P. Wilson, Campfires of Freedom: The Camp Life of Black Soldiers during the Civil War (Kent and London: The Kent State University Press, 2002), xi-xii, xv-xvi, 17-21, 29-30, 33, 39-40, 42-44; Marvin Fletcher, The Black Soldier and Officer in the United States Army, 1891-1917 (Columbia: University of Missouri Press, 1974). 
motivated black naval mutinies in the nineteenth century but a far greater likelihood of it in the twentieth, the white officer-black sailor relationship was dynamic and relative. ${ }^{15}$

The phenomenon of black military mutinies highlights the confrontational aspect of this relationship, but not entirely. The existence of mutinies across generations - concentrated in outbreaks or scattered in isolated incidents-shows that these inter-rank bonds were consistently fragile. Experiences more akin to Emberton's black troops than Glatthaar's can be seen throughout. Yet, the role of white allies to the long emancipation process gives credence to the Glatthaar view. Whites became allies when they fostered conditions that discouraged mutinous behavior, refused to suppress a mutiny, testified on accused mutineers' behalf, and/or demanded more lenient sentences for convicted mutineers. That certain Army units were more prone to rebellion than others, and that until the early twentieth century, soldiers in the Army were more likely to mutiny than sailors, help to validate Fletcher's and Kenner's lessons.

Scholars have used the officer-enlistee relationship within the military justice system to emphasize the new liberties black troops gained. As Ira Berlin notes, while former slaves who enlisted in the Union Army replaced obedience to a master with obedience to a white officer, the majority of black soldiers clearly distinguished the two figures. Slave discipline had an inherently personal, arbitrary nature; military discipline derived from abstract law. Also, black troops understood that military regulations demanded kindness and justice from officers. Army justice gave formerly enslaved black soldiers their first taste of formal legal procedures and rights. Christian Samito reveals that mutineers and those charged with other offenses had access

\footnotetext{
${ }^{15}$ Michael Cohn and Michael K.H. Platzer, Black Men of the Sea (New York: Dodd, Mead, 1978), 68-81; W. Jeffrey Bolster, Black Jacks: African American Seamen in the Age of Sail (Cambridge: Harvard University Press, 1997), 131-157; Steve Sheinkin, The Port Chicago 50: Disaster, Mutiny, and the Fight for Civil Rights (New York: Roaring Brook Press, 2014); John Derrell Sherwood, Black Sailor, White Navy: Racial Unrest in the Fleet during the Vietnam War Era (New York and London: New York University Press).
} 
to counsel, possessed the right to testify and to cross-examine whites, and witnessed a court trying to balance legitimate black grievances with maintaining discipline. Samito cites instances in which strong testimony from witnesses and from defendants themselves helped acquit those accused of mutiny. Officers sometimes commuted capital sentences, and lesser punishments could be suspended if the trial proved defective. Officials treated mutineers with leniency if they determined that officer racism inspired the revolt. According to Samito, the military justice system treated black soldiers equally with whites. ${ }^{16}$ While racism drove many black soldiers to mutiny in the year following the Civil War's end, numerous convictions for the offense preceded sentence reductions and followed trials in which black defendants and witnesses enjoyed the legal rights afforded all U.S. soldiers.

Christian Samito and Ira Berlin use courts-martial to shed light on how white officers and black soldiers grappled with emancipation and compared the harsher aspects of military discipline with slavery. James S. Brisbin, a Pennsylvania abolitionist and brigadier general, placed the responsibility for a black soldier's murder of a white comrade on whites for enslaving blacks. Through mutiny and defending themselves in trial, black soldiers were "refuting their past as slaves now to claim rights as freedmen, soldiers, and citizens." As Samito points out, black mutineers envisioned themselves as U.S. citizens with the full right to equal treatment. Officers such as Colonel Thomas W. Higginson thought that military discipline and regulations would foster self-respect among his troops and help them shift from slavery to freedom. Lieutenant Colonel Henry Stone recognized that the Army must create an environment in which black soldiers interpret an act of disciplinary punishment as a legal action. However, other white

\footnotetext{
${ }^{16}$ Ira Berlin, et. al., Freedom: A Documentary History of Emancipation, 1861-1867, Series II: The Black Military Experience (Cambridge: Cambridge University Press, 1982), 433-436; Christian G. Samito, "The Intersection between Military Justice and Equal Rights: Mutinies, Courts-martial, and Black Civil War Soldiers," Civil War History 53 (June 2007): 170-202.
} 
officers refused to sympathize with black experiences and thought only harsh punishments maintained discipline among men who remained degraded due to their enslaved past. As Ira Berlin explains, "The very distinctions that black soldiers drew between punishments incidental to slavery and those acceptable in freedom reveal the significance of their involvement" in the military justice system. On the one hand, black soldiers often viewed their white officers as new masters and slave drivers. On the other, USCT officers needed to enforce discipline in the ranks. Despite surrendering freedoms given to civilians, black soldiers attained a greater degree of legally-protected equality through their service. ${ }^{17}$ Nevertheless, African-American servicemen living in the long emancipation era served under unsympathetic officers who thought strict discipline and corporal punishment were appropriate for ex-slaves. Since in their minds, punishments in the ranks often came to close to resembling slavery, they thought mutiny was the appropriate reaction.

Since the black mutiny phenomenon targeted the oppressive aspects of the military's wage labor system, it expands on recent studies merging military and labor history. This hybrid military-labor history field has shown that infantry personnel, regardless of race and time period, have performed noncombat manual labor, such as building infrastructure, for low pay and without their consent and have resisted this unfree labor regime. Other military-labor history scholarship explores the primacy of certain soldiers' working backgrounds in pushing them to enlist. Additional historians frame even the combat aspects of soldiering, with its numerous tasks and hardships, as a form of work itself and rebellious actions like desertion and mutiny as labor

\footnotetext{
${ }^{17}$ Christian G. Samito, “The Intersection between Military Justice and Equal Rights," 172-175, 178-179; Ira Berlin, The Black Military Experience, 438-439, 441.
} 
conflicts, which, they argue, deserve a place alongside the civilian subjects of traditional labor history. ${ }^{18}$

The Civil War's USCT mutinies against a particular socioeconomic issue - the government's decision to pay runaway slaves and free blacks in uniform nearly fifty percent less than their white counterparts — also warrant a fusion of military and labor history. Many of those Civil War-era Americans who conducted racially-motivated mutinies first fled an unfree civilian labor system to join one based on wage labor under a government bureaucracy. As scholars have shown, this flight helped destroy the bondage system by draining it of its workforce, mirrored the mobility of antebellum fugitives who went North, and foreshadowed the waves of postbellum black agricultural laborers who moved in search of better employment opportunities. Next, the runaways to Union lines became soldiers in an army of liberation, during which they refused to perform duties, from manual labor to combat functions, until their white superiors resolved the discriminatory nature of their pay scale, the inability of this pay scale to support their destitute families, and unsafe working conditions such as summary punishments. Like other mutinies in world history, those of the USCT show that workers, civilian and military, have refused to perform assigned duties to force concessions from exploitative employers or commanders. ${ }^{19}$

\footnotetext{
${ }^{18}$ For work on the U.S. Army's “enlisted laborers,” see A. Hope McGrath, “A Slave in Uncle Sam's Service': Labor and Resistance in the US Army, 1865-1890" Labor: Studies in Working-class History of the Americas Volume 13:3-4 (December 2016), pp. 37-56. Scholarship on British colonialism has produced rich studies of military-labor history. See Glenford Howe, Race, War, and Nationalism: A Social History of West Indians in the First World War (Kingston: Ian. Randle Publishers, 2002); Humphrey Metzgen and John Graham, Caribbean Wars Untold: A Salute to the British West Indies (Kingston, Jamaica: University of the West Indies Press, 2007); Richard Smith, Jamaican Volunteers in the First World War: Race, Masculinity and the Development of a National Consciousness (Manchester, Manchester University Press, 2004); Peter Way, "Memoirs of an Invalid: James Miller and the Making of the British-American Empire in the Seven Years' War," Rethinking U. S. Labor History: Essays on the Working-Class Experience, 1756-2009, Donna T. Haverty-Stacke, and Daniel J. Walkowitz, eds., (Bloomsbury Academic \& Professional, 2010), 25-53; Reena N. Goldthree, "A Greater Enterprise than the Panama Canal": Migrant Labor and Military Recruitment in the World War I-Era Circum-Caribbean" Labor: Studies in Working-class History of the Americas Volume 13:3-4 (December 2016), pp. 57-82.

${ }^{19}$ For works emphasizing black initiative and mobility in the toppling of slavery, see Stephanie Camp, Closer to Freedom: Enslaved Women and Everyday Resistance in the Plantation South (Chapel Hill and London: University of North Carolina Press, 2004; Steven Hahn, A Nation Under Our Feet: Black Political Struggles in the Rural South
} 
By accompanying the explosion of black civilian strike activity covered by labor historians, the African-American mutinies that hit the Reconstruction-era Army add more to the military-labor history subfield. The civilian and military types of resistance to wage labor each entailed a greater degree of black organizational abilities. John Rodrigue explores how the gang labor of sugar production fostered collective resistance methods among Louisiana's freedpeople during labor struggles with planters. As the free-labor system matured into the 1870 s, they relied on work stoppages or relocations to increase their purchasing power. However, during the sugar strike of 1887 , as planters sought to reduce wages and union-organized workers demanded higher wages and an end to scrip payments, a force of militiamen massacred strikers. After 1887, sugar workers thereby became a rural proletariat. During the late 1870s, in places like Louisville and St. Louis, black members of the Knights of Labor union employed on Jay Gould's railroads struck and conducted educational campaigns denouncing monopoly and advocating public regulation of or ownership over the railroads. When Republican President Rutherford B. Hayes used federal troops to crush the Great Railroad Strike of 1877 in defense of property rights, African Americans who joined the emerging Gilded Age labor movement began appealing not to the GOP but to union organizations. Labor historians have shown that blacks in numerous other southern towns, especially port cities, took advantage of Reconstruction's socio-political climate by forming unions and striking for higher wages and protection from job competition with foreign workers: black washerwomen in Jackson, Mississippi; black waterfront workers in Charleston, South Carolina; and black longshoremen, plantation hands, and millworkers across Florida. These postbellum examples of black working-class militancy demonstrate that the long

\footnotetext{
from Slavery to the Great Migration (Cambridge: Harvard University Press, 2003); John C. Rodrigue, Reconstruction in the Cane Fields: From Slavery to Free Labor in Louisiana's Sugar Parishes, 1862-1880 (Baton Rouge: Louisiana State University Press, 2001); William Cohen, At Freedom's Edge: Black Mobility and the Southern White Quest for Racial Control, 1861-1875 (Baton Rouge: Louisiana State University Press, 1991).
} 
emancipation process became an even greater struggle over labor rights once most black

southerners earned compensation for their work. ${ }^{20}$

As Reconstruction labor historians have also uncovered, slavery's downfall enabled

African-American women to gain a measure of control over their labor. Like men, they

interpreted freedom to mean working without white interference. Many freedwomen withdrew

from agricultural and domestic employment, claiming the privileges of elite white women who

lived leisurely. Other freedwomen resisted white supervision. They stole clothes and other

household items from former mistresses, advocated for land ownership, drove off returning

planters and overseers from plantations on which they worked independently, chose their own

supervisors, set their own work schedule, and organized work gangs. As African Americans of

both sexes took advantage of greater freedom to interact with each other in the years after the

Civil War, black men in uniform occasionally found it necessary to resist white attempts to

regulate this intimate aspect of their lives. ${ }^{21}$

\footnotetext{
${ }^{20}$ John C. Rodrigue, Reconstruction in the Cane Fields; Alan Dawley, "Paths to Power After the Civil War," in Working for Democracy: American Workers from the Revolution to the Present, ed. Paul Buhle and Alan Dawley, (Urbana and Chicago, University of Illinois Press, 1985), 44-45; Tera Hunter, To 'Joy My Freedom: Southern Black Women's Lives and Labors after the Civil War (Cambridge, Mass. and London: Harvard University Press, 1997), 75-76; William C. Hine, "Black Organized Labor in Reconstruction Charleston," Labor History 25, no. 4 (Fall, 1984); Jerrell H. Shofner, "The Pensacola Workingman's Association: A Militant Negro Labor Union during Reconstruction," Labor History 13, no. 4 (Fall, 1972) and Shofner, "Militant Negro Laborers in Reconstruction Florida," Journal of Southern History 39, no. 3 (Aug., 1973).

${ }^{21}$ William Cohen, At Freedom's Edge: Black Mobility and the Southern White Quest for Racial Control, 1861-1875 (Baton Rouge: Louisiana State University Press, 1991); Herbert G. Gutman, The Black Family in Slavery and Freedom, 1750-1925 (New York: Pantheon, 1976); Gerald D. Jaynes, Branches Without Roots: Genesis of the Black Working Class in the American South, 1862-1882 (New York: Oxford University Press, 1986); Jacqueline Jones, Labor of Love, Labor of Sorrow: Black Women, Work, and the Family from Slavery to the Present (New York: Basic Books, 1985); Leslie A. Schwalm, A Hard Fight for We: Women's Transition from Slavery to Freedom in South Carolina (Urbana and Chicago: University of Illinois Press, 1997); Noralee Frankel, Freedom's Women: Black Women and Families in Civil War Era Mississippi (Bloomington and Indianapolis: Indiana University Press, 1999). For accounts of a Virginian mistress complaining about the increasing assertiveness of her "servants," see "Caroline Littlepage Diary, 1864-1867," Virginia Museum of History and Culture, Richmond, VA. Exceptions to this militant wave in Reconstruction scholarship exist. One comes from Greg Downs, who paints the Reconstruction era as one in which needy black and white Americans learned to plead with the government to promote their social welfare. In contrast, mutineers and strikers aggressively demanded more independence. Greg Downs, Declarations of Dependence: The Long Reconstruction of Popular Politics in the South, 1861-1908 (Chapel Hill: University of North Carolina Press, 2014).
} 
This dissertation additionally offers an intersection point for both military-labor history and the scholarship on the officer-enlistee relationship. The long emancipation's mutinies bolster the findings of those works that link the processes of emancipation with physical and cultural forms of slave resistance to white overlords that tried to give blacks greater control over their own lives. Both rebellious slaves and black mutineers revolted against a practice of white oppression that violated their claimed right to live free from physical abuse and from regulations over their bodies. To be sure, the officer-soldier relationship did not reach the level of domination characterizing that of masters and slaves. Yet, the defiance seen in both relationships served the same goal of weakening white supremacy. Also, the officer-soldier relationship can be seen as a military counterpart of the employer-employee relationship in the wage labor economy. Mutineers and strikers alike revolted against superiors who mistreated them and deprived them of the fruits of their labors. ${ }^{22}$

Finally, by incorporating the mutinies of both black soldiers and black sailors, this project bridges gaps in military history. In Civil War historiography especially, the vast majority of scholars exclusively study the Army while a tiny number fill in gaps in naval knowledge. Decrying specialization, Cornelis Lammers once called on future works to compare both land and sea-based mutinies, the "dry" and "wet" kinds, rather than one or the other. In examining both the dry and wet mutinies of African-American servicemen, this dissertation sheds greater light on the long emancipation than if it limited itself to one military branch. ${ }^{23}$

\footnotetext{
${ }^{22}$ For links between slave resistance and emancipation, see Stephanie Camp, Closer to Freedom. Camp documents bondspeople who challenged the master regime restricting the movement of slave bodies with patrols and passes through clandestine movements, thereby creating a "rival geography" through which they fled to Union lines during the Civil War. Another segment of the literature notes how African Americans worshipped their own version of Christianity under slavery, often secretly, before establishing independent black churches after emancipation.

${ }^{23}$ Cornelius J. Lammers, review of Rebellion, Repression, Reinvention, by Jane Hathaway, 481. It is beyond the scope of this project, however, to follow his second call: the writing of comparative studies of army and naval mutinies in different countries.
} 
The body of this dissertation structures itself according to both military branch and chronology. While most chapters cover Army mutinies, its bookends feature the other branches of the armed forces that contended with rebellious black men. The work opens with a study of why so few black naval personnel throughout the long nineteenth century mutinied compared to the Merchant Marine's black sailors. The unique race relations seen on the ocean compel us to reframe how scholars understand the narrative of black resistance and emancipation. Moving from sea to land, Chapters 2 through 5 examine the Army's experience with African-American mutinies. The second, third, and fourth analyze the three eras of the United States Colored Troops (USCTs): Civil War, immediate postbellum period, and early postwar Reconstruction. With the peculiar institution in free fall, the first USCT mutineers sought to rid the Union Army of anything reminiscent of slavery, especially insufficient compensation for their labor and cruel abuse from their superiors. When the twin causes of Union and emancipation triumphed in the summer of 1865, a second wave of mutinous USCTs arose out of men's despair over learning that instead of going home, they would relocate a thousand miles away while suffering the most acute examples of white officer cruelty of their careers. Meanwhile, as the last remaining USCTs conducted occupation duties in the Reconstruction South, they combatted counter-revolutionary white civilian communities. Chapter 5 looks at the next half century of African-American Army history, focusing on the Buffalo Soldiers. Stationed in the West, these regular troops reacted against grievances held over from the USCT eras as well as their country's regression from the promises of Reconstruction to the disappointments of Jim Crow. In the conclusion, the dissertation comes full circle, giving an overview of the massive wave of African-American soldiers, sailors, and airmen who rose up during watershed twentieth-century conflicts. The revolts of World War II and the Vietnam conflict both built on the previous century of black 
mutinies while also paving the way for, and growing out of, the protests of the modern civil rights movement.

Regardless of where in the armed forces or when they served, African-American men in uniform during the long emancipation process vigilantly protected their rights to control their bodies and destiny, keep their families intact, and enjoy the fruits of their labor. These mutinies occurred as an old racial caste system collapsed and a new oppressive order emerged to replace it. As long as any white supremacist system existed in some form, multiple generations of black servicemen rose up in a desperate effort to finally secure their long-overdue freedom. 


\section{Chapter 1}

\section{Masters of the Vessel: African-American Mutinies on the Nineteenth-Century Sea}

On July 7, 1861, William Tillman, a free black merchant sailor, discovered the combined promise and peril of the Atlantic Ocean facing generations of African Americans. By pursuing a maritime career, the twenty-seven-year-old Rhode Islander, cook, and steward occupied a cosmopolitan world in which he possessed greater opportunities for advancement as a black man than he could hope for on land. However, before his ship, the S. J. Waring, could dock at New York, he needed to fight to prevent his enslavement, adding to a tradition of resistance begun by his Middle Passage ancestors. On that July day, slave trading privateers of the Jefferson Davis took command of the vessel as part of the Confederacy's irregular naval war against the Union blockade and northern ships. Planning to sell Tillman and the other black crewman into bondage in Charleston, South Carolina, the privateers assigned a prize crew of six to carry out the plan. Declaring that he was "not going to Charleston a live man" and that "they may take me there dead," Tillman organized an uprising with his shipmates. In the middle of the night of July 16, they beat the prize crew members with clubs or axes, killing three and dumping their bodies overboard. Passenger Bryce Mackinnon provided graphic eyewitness testimony in the press, describing how the mutineers' weapons cleaved the Confederate sea captain's skull, cracked that of the mate, and continuously fell on persons pleading for their lives. As one abolitionist later documented, the "black man," meaning Tillman, had become "master of the vessel." Under Tillman's leadership, the liberated crew safely arrived in New York harbor on July 21, 1861. Occurring more than a year before the Union embraced emancipation as a war aim, the jubilant New York welcome party viewed the Waring mutiny as a triumph for the Federal cause.

While contemporaries never used the word "mutiny" to describe William Tillman's actions, its features - a subordinate individual using defiant language, wielding weapons, 
disrupting the regular course of a workplace's duties, and aggressively subverting an established command hierarchy, all in the interest of correcting an injustice-qualify it as such. Its goal of preserving the free status of its perpetrators against white supremacist forces in a military context, albeit of the unconventional sort, additionally makes it a notable episode of the phenomenon of black mutineers advancing the long emancipation process. ${ }^{24}$

William Tillman's experience personifies much of the story of nineteenth-century African-American sailor mutinies, though black merchant seamen like him shared the water with bondspeople and the U.S. Navy's black sailors. Evidence demonstrates that until the turn of the twentieth century, the emancipation process was relatively more advanced on the seas than on land. It also reveals that the "wet" theater of this process took an especially convoluted trajectory where human cargo, merchant sailors, and naval servicemen respectively formed a spectrum from furthest and closest to realizing the goals of the long emancipation. Tillman's status as a merchant sailor who fought an irregular naval battle to prevent his enslavement placed him at the intersection of all three groups.

If Tillman had joined the Navy, it is likely that he would have never conducted a seaborne revolt. While other chapters mainly explore why numerous generations of African-

\footnotetext{
${ }^{24}$ Charles S. Greene, Thrilling Stories of the Great Rebellion (Philadelphia: John E. Potter and Co., 1864), 23-25 (first quote on 23); William Brown, The Negro in the American Rebellion: His Heroism and His Fidelity (Boston: Lee and Shepard, 1867), 74-76 (second quote on 75); “The Lion of the Day," Harper's Weekly, Aug. 3, 1861, https://opinionator.blogs.nytimes.com/2011/08/04/the-lion-of-the-day/; Brian McGinty, The Rest I Will Kill: William Tillman and the Unforgettable Story of How a Free Black Man Refused to Become a Slave (New York: Liveright, 2016); C.R. Gibbs, "Blacks in the Union Navy," Negro History Bulletin, volume 36, no.6, (1973), p. 138; Michael S. Davis, "'Many of Them are Among my Best Men': The United States Navy Looks at its African American Crewmen, 1755-1955," PhD Dissertation, Kansas State University, 2001, 43. With defeats like Fort Sumter and First Bull Run fresh in their minds, New Yorkers gave Tillman a hero's welcome. The New York Tribune proclaimed that, "To this colored man was the nation indebted for the first vindication of its honor on the sea." Quoted in William Brown, The Negro in the American Rebellion, 75. The feat earned him a \$6,000 award. According to McGinty, the Civil War's development—ever-larger battles and casualty rates—quickly and thoroughly overshadowed Tillman's story to the point that the country forgot it. Tillman thereafter almost disappeared from the historical record. Due to its semi-military nature, his mutiny can be considered an example of the unconventional battles fought within the broader Civil War, blending the boundaries of Merchant Marine and Navy history, just as land-based guerrilla warfare blurs the lines between military and civilian social history.
} 
American servicemen conducted numerous rebellions against white supremacy, the current one in part asks why a certain component of this group seemingly did not do so or at least were less likely to during the same time period. In contrast to the plethora of mutinies in the U.S. Army during the long emancipation period, such events prove elusive to the researcher of AfricanAmerican naval history before the Second World War. African Americans mainly felt the need to resist on water when they were still enslaved or if they toiled on repressive merchant ships.

To be sure, a level of racial tensions and discrimination existed in the nineteenth-century U.S. Navy. Black sailors found the highest ranks closed off to them, and the Civil War's influx of runaway slaves aggravated many white sailors. However, the existence of integrated crews until naval ship reorganization in the early twentieth century corresponds to a small number of racially motivated black mutinies in the historical record. The documented mutinous behavior that did involve black naval sailors during this period tended to have motivations common to the goals of both the black freedom struggle and white men struggling to attain their own masculine independence. Otherwise, the racially-motivated mutinies that erupted on U.S. naval ships were of the white supremacist variety. It was not that rebellion categorically was rare among sea-borne African Americans compared to those laboring and serving on land; it depended greatly on the nature of their status on a particular ship. The complex story of black resistance on the seas will help us further construct a theory on why mutinies borne of racial animosities broke out.

This chapter presents an overview of African-American naval history from the birth of the United States to the dawn of Jim Crow, all while highlighting the ways in which it intersected with the history of blacks in the Merchant Marine and the Atlantic slave trade. While navigating this era, it highlights key moments and developments to explain why black naval personnel rarely appeared to engage in acts of resistance to combat white supremacy and promote social 
equality, but nevertheless came from a tradition of insurrection forged by bondspeople transported on slave ships and African-American sailors laboring on merchant ships. While certain factors forestalled mutinies in the Navy, these were less likely to be present across much the land-based armed forces. On water, blacks enjoyed permission to enlist and performed their duties in integrated spaces due to a combination of commanders' pragmatic concerns and the influence of white allies. It was not until the Civil War that blacks could serve their country on land in a permanent capacity, and only then in segregated units. The interplay of pragmatism and biracial alliances proved key to black freedom on land and sea.

This chapter ends by paving the way for the conclusion's coverage of the Navy in the first three quarters of the twentieth century, when it ceased being the sole integrated component of the U.S. military and moved in the same white supremacist direction as the rest of the services. After so many years during which the sea offered greater economic independence and upward social mobility, the water became just as unwelcoming to individuals with dark skin as the solid ground. Despite this turn of events, more than any other branch, naval service gave African Americans during the long nineteenth century the closest they ever came prior to the modern civil rights era of enjoying relative equality of opportunity and fair treatment while in uniform.

That the Navy's race relations were so different from the Army's in the pre-Jim Crow decades and then so alike by the time of the modern civil rights movement testifies to the nonlinear nature, and complex trajectory, of the long emancipation process. Blacks across generations could hope for a better world, realize something resembling that world for a time, and then find their people regressing into another oppressive racial caste system. AfricanAmerican scholars have proven the existence of this trajectory in political, socioeconomic, and 
military scholarship, ${ }^{25}$ but analyzing why black men did or did not mutiny across different military branches in multiple time periods more clearly illustrates this contingency in U.S. race relations. Martin Luther King, Jr., famously declared, and many Americans have since repeated, that "The arc of the moral universe is long, but it bends toward justice." However, black servicemen have occasionally needed to actively bend the moral universe toward justice themselves. As multitudes of them learned at one time or another, if they were insufficiently vigilant or if events otherwise escaped their control, this arc was often, if not always, in danger of reversing course away from justice. ${ }^{26}$ By taking advantage of the unique circumstances of life at sea, black sailors gained an edge in this struggle.

To develop explanations for the glaring absence of black mutinies on U.S. naval ships in pre-twentieth-century America, the current chapter uses the scholarship on African-American maritime history, civilian and military, as a starting point. As this field demonstrates, men of African descent have served in American naval forces since the colonial period. Historians show that in doing so, blacks have encountered unique prospects for, and barriers to, the goals they devised for their freedom and emancipation. This chapter merges two areas of scholarshipgeneral histories of naval mutinies and those of black maritime history - taking an AfricanAmerican history approach with the former and forging a military history analysis out of the latter. Previous black maritime scholarship established the importance of the topic to the long-

\footnotetext{
${ }^{25}$ Here the author references the country's cyclical expansion and contracting of black citizenship rights in general, illustrated by the following examples: the movement from slavery to a biracial democracy in the Civil War and Reconstruction; Redemption's overthrow of Reconstruction; and the emergence of Jim Crow in the 1890s followed by its collapse between the 1940s and 1960s.

${ }^{26}$ Dr. Martin Luther King, Jr., speech at the National Cathedral, March 31, 1968, https://www.si.edu/spotlight/mlk?page=4\&iframe=true (quote). For present-day discussions on the meaning of King's quote and skepticism over whether it accurately describes American society, see Mychal Denzel Smith, "The Truth About "The Arc Of The Moral Universe,"” Huffington Post, https://www.huffpost.com/entry/opinion-smithobama-king_n_5a5903e0e4b04f3c55a252a4; CBS, Interview of Eric Holder, 2016, https://www.cbsnews.com/video/how-far-have-we-come-on-the-arc-of-justice/.
} 
term black freedom struggle. The current work builds upon that foundation by focusing more narrowly on what water-based mutinies, or the lack thereof, tell us about the struggle's progress.

Researching African-American naval history in general and black sailor mutinies in particular poses a set of challenges that have prevented these subfields from becoming as rich as African-American soldier history. Most prominently, since ships were integrated, it is challenging to confirm the racial backgrounds of most crew members. In the historical record, maritime entities rarely identified sailors' skin color. Complicating the matter further is how naval court-martial records are arranged by date, not alphabetically. The lack of segregated units also makes this research more difficult. Other sources or references are needed to determine an individual's race. Enlistment documents typically list the sailor's complexion, but the high number of duplicate names makes unclear which specific individual was being tried. ${ }^{27}$

Overall, the seas proved to be a double-edged sword for African Americans since their ancestors first arrived on slave ships. It was through human navigation across the Atlantic Ocean that the trade in humans and the products of slave labor first emerged. Between the sixteenth and nineteenth centuries, millions of West Africans suffered an agonizing experience during the Middle Passage. Slave traders kidnapped them from their homes and transported them to the African coast, where the former tightly stuffed the latter into ships as human cargo constrained by chains. After a brutal voyage, the survivors spent the rest of their lives as coerced laborers and the property of another person. Captives suffered a multitude of traumas: the anguish of being

\footnotetext{
${ }^{27}$ This particular barrier to naval research has long been known; in 1842, the Navy Department told Congress the same in response to a request for an estimate on how many African Americans served in the branch. Secretary A. P. Apshur to Speaker John White, August 5, 1842, https://www.history.navy.mil/research/library/online-readingroom/title-list-alphabetically/c/colored-persons-in-the-navy.html; "Web: US, African American Civil War Sailor Index, 1861-1865," https://www.ancestry.com/search/collections/9748/. Rather than scanning the names of Army soldiers the researcher knows for certain are African American because the finding aids list defendants by their segregated unit and then alphabetically, he or she needs to dig further to research the Navy's Sable Arm. Scholars can now access an Ancestry.com database of every African American who served in the Union Navy. However, such digitization exists for neither antebellum nor postbellum sailors.
} 
forcibly separated from their kin; the dread of seeing the vessel off coast; the confusion of seeing European sailors for the first time; the sensory discomforts of residing in crammed, hot quarters filled with human waste, perspiration, and disease; the physical pain of floggings; and the combined curiosity and fear regarding what new horrors awaited them on the other side of the Atlantic. In a precursor to naval service, slave ships possessed elements of a warship/naval vessel: captains imposed unilateral, stern discipline on the crewmen as well as slaves, and ships were armed with cannons with which they could wage imperial conflict. Aboard slave ships, captured Africans began forging a common culture and devising ways to resist, escape, or better endure bondage. These coping mechanisms shaped the lives of all subsequent generations of African Americans during and after slavery. ${ }^{28}$ The sea constituted the lifeline for the trade in human property, that institution which created the need for African Americans to wage a struggle for freedom in the first place.

Ironically, the same bodies of water that contributed to their enslavement later offered black Americans opportunities to acquire or bolster their freedom, including boats that sailed to locations that had outlawed slavery. South Carolina slaves like John Andrew Jackson escaped via Charleston harbor in 1846. Following the death of a despotic slaveholder due to inherit him, Jackson concluded that "God willed me to myself" and left the plantation on which he brutally toiled. Concealing himself in the harbor's wharves, he searched for a vessel due to sail to a free state. When dockworkers demanded that he inform them to whom he belonged, he gave a curious reply: "I belong to South Carolina." According to Susanna Ashton, "he was...trying to belong to a broader South Carolina identity that would not claim him." He could not find a

\footnotetext{
${ }^{28}$ Olaudah Equiano, The Interesting Narrative of the Life of Olaudah Equiano Or Gustavus Vassa, the African, Written by Himself (London: Author, 1794), 30-57; Marcus Rediker, The Slave Ship: A Human History (New York: Viking Penguin, 2007), 6, 9.
} 
dockworker willing to assist him, but he located a ship heading to Boston and hid between two cotton bales in a four-by-three-foot space. As the boat moved "side to side," Jackson realized that he was "now upon my journey from slavery to freedom." Reaching free territory in February 1847, Jackson recollected in 1862 that "felt as I have never felt before - that is, master of myself." The sea thus enabled coastal slaves to give substance to claims of self-ownership, undermining the South's racial hierarchy. Escaping slavery over water, in a reversal of the Middle Passage, constituted a major symbolic victory for runaways, both metaphorically and physically. ${ }^{29}$ Despite the great threats to their freedom that the seas presented, African Americans found ways to use them to their advantage. This dual nature of waterways characterized the black relationship with it during the entirety of the long emancipation period.

Works on black maritime history accompanied the explosion in African-American history scholarship unleashed by the modern civil rights movement. This wave demonstrated that the black struggle for greater social equality took place not just on land, but also at sea. The black sea experience consisted of more than the one-way trip of those sold into the colonial Atlantic slave trade or antebellum domestic slave trade and included whaling, pirating, commercial shipping, voluntarily immigration, flight from slavery, and naval service. Despite their status as fundamental players in U.S. maritime history, blacks faced various threats: re-enslavement, performing the worst and most dangerous jobs, restrictions at port, and employment barriers. Yet, maritime service also afforded them chances to explore the world and attain positions of authority, which elevated their self-image and social standing. Across the centuries, African

\footnotetext{
${ }^{29}$ John Andrew Jackson, "The Experience of a Slave in South Carolina," 1862, in Susana Ashton, I Belong to South Carolina: South Carolina Slave Narratives (Columbia: University of South Carolina Press, 2010), 83 (first quote), 1 (second and third quotes), 106 (fourth quote), 84 (fifth quote), 4, 85-126. The most famous runaway slave of the antebellum period, Frederick Douglass, took a land-based train to freedom but did so disguised as a free black sailor. See Frederick Douglass, Narrative of the Life of Frederick Douglass, an American Slave: Written by Himself (Boston: Anti-Slavery Office, No. 25 Cornhill, 1845), 107-115.
} 
Americans in the Navy, Merchant Marine, and in port occupations played key roles in combating racism in the armed forces and the injustices blacks faced on and off shore. ${ }^{30}$ Overall, earning a living toiling on the water provided a better livelihood for blacks than what land offered them.

Blacks' experiences on nineteenth-century waters built on an extended past during which their ancestors utilized seafaring for financial gain. The maritime traditions of Africans and their descendants originated in the ancient world, when various cultures circled the continent to conduct trade. Long before Europe's arrival in West Africa, its inhabitants mastered navigation of coastal and inshore waters to hunt aquatic life. Preserving these skills helped African Americans across the centuries, before and after liberation from bondage, better able to become economically independent and preserve their traditional culture. Bondsmen performing this labor enjoyed greater autonomy than field hands, and runaways utilized water transportation methods to hide in swamps. From the seventeenth century onward, native-born and immigrant whites, free and enslaved blacks, served as crewmen on coastal trade ships transporting food and fuel. Coastal trades faced perpetual labor shortages, allowing African Americans to move up the ranks. Whaling ships possessed the most diverse crews, bringing men together from the entire Atlantic World. Both coastal trades and whaling promoted African Americans to captain. ${ }^{31}$ Shipbuilding especially gave blacks opportunities for upward mobility. Before emancipating himself, Frederick Douglass worked as a caulker in Baltimore's shipyards alongside free blacks. There, a white sailor assisted the future abolitionist lecturer in escaping to freedom in the North. These heavily African-American worksites organized under the Caulkers' Association in 1838. The union empowered them to negotiate for higher wages and better

\footnotetext{
${ }^{30}$ Michael Cohn and Michael K.H. Platzer, Black Men of the Sea (New York : Dodd, Mead, 1978), xiii-xiv; Martha Putney, Black Sailors: Afro-American Merchant Seamen and Whalemen Prior to the Civil War (New York: Peter Lang, 1989).

${ }^{31}$ Michael Cohn and Michael K.H. Platzer, Black Men of the Sea, 1-2, 7-9, 39-47, 82-90.
} 
working conditions. In making wooden ships watertight, caulkers like Douglass performed a skilled form of labor and enabled the border state city to become a maritime commercial power during the early national period. ${ }^{32}$ Thus, the point where land and ocean met proved essential to black victories in the otherwise white supremacist American labor movement.

African Americans also formed a large part of the nineteenth-century Merchant Marine. Northern emancipation in the early nineteenth century opened up numerous opportunities for blacks in the institution. Despite legally-mandated racial quotas on vessels, labor demands kept the number of African-American sailors and the extent of racial integration on ships high into the twentieth century. Blacks made up between a quarter and half of the expanding American merchant fleet's population by 1850 , dwarfing their proportion in the general population. They labored as pilots, shipwrights, deckhands, and stevedores. The Merchant Marine developed a hiring policy based more on merit than race. Though employers exploited racial tensions through job competition, the nature of life at sea fostered biracial bonds. Sailors, regardless of color, endured the same harsh existence: long hours, powerful weather, disease, insufficient food, and tyrannical captains who enforced discipline through the threat of irons and the lash. As scholars of black maritime history note, while serving in the Merchant Marine, black seamen lived at the intersection of multiple cultures: African-American, white, and Atlantic. Comparable to naval ship integration, culturally diverse merchant vessels fostered camaraderie and wage parity. While their jobs were commercial, not military, in nature, African Americans working on merchant ships lived under a disciplinary regime and cultural environment not unlike that which characterized naval service. ${ }^{33}$ Black maritime history in general blends labor and military history.

\footnotetext{
${ }^{32}$ Ibid., 48-57; Frederick Douglass, Narrative of the Life of Frederick Douglass, 43-44, 93-107. Decades later, to meet labor demands, both world wars brought a flood of African Americans to the shipbuilding industries.

${ }^{33}$ Michael Cohn and Michael K.H. Platzer, Black Men of the Sea, 68-81; W. Jeffrey Bolster, Black Jacks: African American Seamen in the Age of Sail (Cambridge: Harvard University Press, 1997), 131-157.
} 
However, following the mid-century mark, the quantity and quality of maritime jobs declined for blacks. When African Americans could find maritime employment, it tended to be of the menial sort, as cooks and stewards. They gradually lost their "community of labor" with other black sailors, forcing them to rely on eroding biracial bonds. By the end of the century, changing capital investments, low-wage European immigration, and recruiting agents who prioritized whites all displaced black sailors. A parallel, more gradual, decline in African Americans' position in the Navy took place around the same time period. Despite demographic shifts, remaining African Americans in the Merchant Marine played active roles in the Gilded Age labor movement. They helped organize the Atlantic Coast Seamen's Union, the 1893-1894 winter strike (which shut down half of the country's deep-sea tonnage), and the Marine Firemen's Union. ${ }^{34}$ Like black caulkers earlier in the century, black merchant sailors understood the need to organize against threats to their livelihood and economic independence. Such a course was key for them to forestall or reverse a regression in their emancipation process.

Various realities across the Atlantic World complicated the extent to which the sea placed African Americans, civilian and military, further along in the long emancipation process during the first half of the nineteenth century. First, ships and southern naval yards employed slaves for most of the early nineteenth century, with their wages going to their masters, as in other hiringout arrangements. Also, despite free blacks' higher wages and relatively greater equality on the water, numerous reminders of the tenuous nature of their liberty existed. When their ships docked near plantations at which bondspeople toiled, a white sailor acquired an opportunity to

\footnotetext{
${ }^{34}$ W. Jeffry Bolster, “'To Feel Like a Man,' Black Seamen in the Northern States, 1800-1860," Journal of American History, Vol. 76, No. 4 (Mar., 1990), 1173-1199; Michael Cohn and Michael K.H. Platzer, Black Men of the Sea, 58-67.
} 
sell a black shipmate into bondage. ${ }^{35}$ The emancipation process for black sailors was far from linear; one's progress depended on time period, geography, and contingency on macro and micro factors. Not only did slavery end in different countries and regions at various times, but the systems replacing bondage in Atlantic societies underwent their own uneven trajectories.

Among the greatest challenges civilian black seamen faced to their freedom while situated in ports included regulations governing the coastal areas of the antebellum American South. In 1822, South Carolina's state legislature passed a law requiring the confinement of free black seamen while their merchant ships occupied the Palmetto State's ports. It also stipulated that if the captain neglected to pay for the imprisonment, authorities would sell the sailor into slavery to cover these costs. During the remaining antebellum decades, various other states along the southeast coastline passed similar "Negro Seamen Acts." Sailors affected by enforcement of the laws spent anywhere from days to years in prison. During these suspensions of their freedom, African Americans endured corporal punishment and convict labor. The motivations for these regulations were two-fold. First, slave states were worried that free northern or foreign blacks would incite slave insurrections modelled off of what Denmark Vesey, a free black man, had led prior to the enactment of South Carolina's law. Secondly, after the British Empire ended its own system of bondage, southern states expected it to liberate American slaves. ${ }^{36}$

\footnotetext{
${ }_{35}$ James E. Valle, Rocks \& Shoals: Order and Discipline in the Old Navy, 1800-1861 (Annapolis: Naval Institute Press, 1980), 20; Michael Alan Schoeppner, "Navigating the Dangerous Atlantic: Racial Quarantines, Black Sailors and United States Constitutionalism," PhD Dissertation, University of Florida, 2010, 8.

${ }^{36}$ Michael Alan Schoeppner, "Navigating the Dangerous Atlantic," 8-10. As evidenced by the backlash to them, these acts fueled sectional and international tensions. Northerners and the British government lashed out in protest, citing the ways in which the acts interfered with interstate and foreign commerce and violated black citizenship rights. While state courts upheld the laws' constitutionality, federal courts and attorneys general disagreed. Northern and federal attempts to investigate the laws received angry invocations of states' rights philosophy and failed to prevent future parts of the Confederacy from enforcing these violations of free black sailors' rights. Yet, the rise of Jacksonian Democracy brought federal officials like Attorney General Robert Taney, who issued a little-known ruling in 1831 that foreshadowed his infamous Dred Scott decision a generation later. Asserting that African Americans were "a separate and degraded people" who could only enjoy whatever rights and privileges individual whites voluntarily granted out of kindness, the future chief justice dismissed the basis of the anti-Seamen Act argument. See Leon F. F. Litwack, North of Slavery: The Negro in the Free State (Chicago: University of Chicago
} 
Linking these two factors together, by the nineteenth century, the Atlantic World had also entered an era in which proslavery ideologies competed with the natural rights philosophies unleashed by the most radical elements of the American, French, and Haitian Revolutions. As Michael A. Schoeppner describes the Seamen Act policy, imprisoning or enslaving free black sailors amounted to a "quarantine" from the ideologies espousing freedom as a birthright, ideas which these sailors threatened to convey to the local bondspeople. ${ }^{37}$

Despite the rarity of black naval mutinies during the nineteenth century, enslaved and free black merchant sailors engaged in frequent acts of unrest and resistance. While land-based revolts such as those of Nat Turner, John Brown, and Denmark Vesey failed, the antebellum era's wet slave rebellions enjoyed a remarkable degree of success. Enslaved sailors could more easily seize power over the sites of their bondage because ships were smaller and more isolated than plantations, making it more difficult for proslavery forces to quell them. If an insurrection succeeded, the liberated could then sail the ship to free land, bypassing slaveholding territory.

Blacks began conducting rebellions on the water from the time Atlantic slave traders kidnapped them. With the English Empire increasingly using slave labor alongside indentured servants by the mid-seventeenth century, its ships occasionally met the fate of one that set anchor in Gambia in 1651. The boat's captors "got weapons in their hands, and fell upon the Saylors, knocking them on the heads, and cutting their throats." Incidents like this became so frequent that the Guinea Company directed ships to carry shackles and bolts with which to constrain "your negers as are rebellious," as well as to keep bondspeople fed "in due season that they ryse not against you." White slavers hired other African peoples to detect signs of insurrection by

Press, 1965), 51-53; Philip M. Hamer "Great Britain, the United States, and the Negro Seamen Acts, 1822-1848," Journal of Southern History Vol. 1 (February 1935): 3-28.

${ }^{37}$ Michael Alan Schoeppner, "Navigating the Dangerous Atlantic," 8-10. 
living among and sleeping next to the enslaved, and to whip resisters. On another ship, a group of these black guards crushed an uprising when they shot thirteen rebels. In 1750, four rebellious slaves aboard The Wolf suffered the penalty of drowning. Revolt always carried great risks. ${ }^{38}$

Just like Army mutinies involving individuals of African descent, the above persons faced a range of choices: resist and risk death; or save oneself by either staying clear of the violence or by aligning with those in power, the slavers. Early colonial slave ship mutinies demonstrate that the long emancipation process needed individuals to engage in violent resistance to advance itself forward from the moment that African peoples first found themselves at the bottom of a racial caste system operated by those of European descent. Moreover, the guidance slave ships issued to each other revealed that whites understood that dominating black bodies and depriving them of the means of subsistence and control over their own destinies were the main drivers of revolt, the first step of the long emancipation process.

This tradition of resistance continued into the nineteenth century as black sailors aboard slave ships, taking advantage of British emancipation, mutinied. One evening in early November 1841, a group of enslaved American sailors took advantage of the international abolitionist movement's successes to emancipate themselves. In early November 1841, a group of enslaved sailors mutinied aboard the merchant ship Creole while it sailed from Richmond to New Orleans transporting tobacco and one hundred and thirty-five slaves. The Creole was a component of the domestic slave trade, which redistributed people, wealth, and crops from the Upper to Lower South during the antebellum period. ${ }^{39}$

\footnotetext{
${ }^{38}$ Peter Linebaugh and Marcus Rediker, Many-Headed Hydra: Sailors, Slaves, Commoners, and the Hidden History of the Revolutionary Atlantic (Boston: Beacon Press, 2000), 129 (quotes); Michael Cohn and Michael K.H. Platzer, Black Men of the Sea, 20-21; Diary of Dr. William Chancellor, 1749-1751, E. A. Williams Papers, H. Furlong Library, Maryland Historical Society, Baltimore, Maryland.

${ }^{39}$ For studies of the domestic slave trade, see Steven Deyle, Carry Me Back: The Domestic Slave Trade in American Life (Oxford and New York: Oxford University Press, 2005); Walter Johnson, Soul By Soul: Life Inside the Antebellum Slave Market (Cambridge and London: Harvard University Press, 1999). The most famous seaborne
} 
Building on earlier resistance to bondage, Madison Washington played a prominent role in the Creole mutiny. Having earlier fled Virginia for Canada along with other fugitive slaves, Washington formed ties with British abolitionists and Underground Railroad operators. He came aboard the Creole after slavers captured him while he attempted to free his wife in the Old Dominion. Following Washington's leadership, eighteen other rebellious slaves shot, struck, and stabbed the white crew members and slaveholders aboard the Creole, killing one and mortally wounding another. Both sides incurred several minor injuries, and four bondspeople died. Washington reportedly verbally commanded the mutineers, proclaiming that "We have begun and must go through. Rush, boys, rush aft, and we have them!" After taking control of the vessel and keeping the second mate, his family, and the captain in custody, the mutineers demanded that the mate send them to the territory of an empire that had recently abolished slavery. When the brig arrived at Nassau, in the British Bahamas, which had a large black population, the American consul treated the wounded captain and others on board, and kept the slaves from coming ashore. U.S. authorities jailed them, but the governor refused to repatriate them, considering the slaves free because the British lacked the jurisdiction over the mutiny and murder charges of which white Americans accused the mutineers. The British colonists thus treated the mutineers as passengers with freedom of movement, in contrast to the consul, who

bondsperson mutiny of the nineteenth century took place on the Spanish schooner Amistad, part of the Atlantic slave trade. In late June 1839, the ship set sail from Havana to Port Principe with a cargo of fifty-four slaves captured from Sierra Leone. On the fourth night at sea, the enslaved launched an uprising, breaking their chains, slaying the captain and three crewmen with knives, and setting course for a return voyage to Africa. Circulating reports of a black-manned ship "of suspicious and piratical character" prompted the U.S. Navy to pursue it. After discovering the target on their backs and realizing that they had reached free territory in North America amidst going ashore for supplies, in August, the mutineers surrendered to the USS Washington near Long Island. In 1841, citing the illegality of the slave trade and the lack of a treaty with Spain protecting slave property, lower courts and the U.S. Supreme Court declared the thirty-six mutineers free and ordered them released, endorsing the right of kidnapped peoples to violently defend their liberty. By 1842, the American Missionary Association aided the Amistad rebels back to their West African homes. See John W. Barber, A History of the Amistad Captives (New Haven, Connecticut: E. L. and J. W. Barber, 1840), quotes on 19, 1; Howard Jones, Mutiny on the Amistad: The Saga of a Slave Revolt and Its Impact on American Abolition, Law, and Diplomacy (Oxford: Oxford University Press, 1987); Marcus Rediker, The Amistad Rebellion: An Atlantic Odyssey of Slavery and Freedom (New York: Penguin Books, 2013). 
contended that they were a portion of the ship's cargo. While some emigrated to Jamaica, and five refused the offered emancipation and returned to the U.S., most remained in Nassau following their liberation. For successfully freeing themselves, the Creole mutineers became heroes in abolitionist circles. Meanwhile, with British authorities ordering the emancipation of American slaves, white southerners raged, straining Anglo-American relations and fueling sectional tensions over the legality of the peculiar institution. ${ }^{40}$

Antebellum black resistance on the seas involved free African-American civilian sailors as well. In February 1846, a violent mutiny consumed the barque Cactus. Baltimorean John Harding killed the second mate by fracturing his skull, and a Virginian named William Grimes acted as the ringleader. Other mutineers hailed from New Jersey, Bermuda, and Portugal, giving the rebellion an international flavor common on merchant and naval ships. The incident resulted from the officers harshly disciplining sailors with whippings and beatings with handpikes for minor offenses. After refusing to clean the decks, the mutinous crew used these same handpikes as weapons against their officers. Once the captain acquired his pistol and the cabin boy gave a cutlass to the first mate, the officers restored order. While getting ready to strike the first mate next, Harding backed off and dropped the handpike upon seeing the firearm. The officers placed Harding in irons and compelled the rest of the crew to resume their duty in submission. During the remainder of the voyage, the officers dreaded a second outbreak. The Baire Patriot referred

\footnotetext{
40 "Mutiny and Murder," The Daily Picayune, December 3, 1841, https://infoweb-newsbankcom.www.libproxy.wvu.edu/iw-search/we/; Milledgeville Southern Recorder, March 8, 1842, https://access.newspaperarchive.com/; Milledgeville Southern Recorder, January 18, 1842, Ibid; "Case of the Comet," The Liberator, December 31, 1864, https://infoweb-newsbank-com.www.libproxy.wvu.edu/iw-search/we/; Stanley Harrold, "Romanticizing Slave Revolt," in Antislavery Violence: Sectional, Racial, and Cultural Conflict in Antebellum America, eds., John R. McKivigan and Stanley Harrold (Knoxville: University of Tennessee Press, 1999), 89-107, quote on 91. See Harrold's piece for an examination of how contradictory abolitionist rhetoric both celebrated slave revolts and subscribed to notions of black passivity. Also see Jeffrey R. Kerr-Ritchie, Rebellious Passage: The Creole Revolt and America's Coastal Slave Trade (New York and Cambridge: Cambridge University Press, 2019.
} 
to the "negroes of different nations" working on the ship as "that worst description of crews." In April of that year, the U.S. revenue schooner Forward arrived in Philadelphia with seven mutineers from the Cactus, all of whom were black. A civilian court convicted Harding of mutiny and manslaughter and gave him a three-year prison sentence. ${ }^{41}$

Regardless of mutineers' racial composition, Americans understood that corporal punishment like that seen on the Cactus was the most likely of all aspects of life at sea to drive crews to rebellion. During a congressional debate over the utility of flogging in the Navy, a senator described the "barbarous, degrading, and humiliating" practice as "a system so repulsive to the feelings of a man, that it ought to produce mutiny." Additionally, sailors wrote exposés in which they confirmed that the practice bred mutiny. They pointed to how the lash contradicted their citizenship and manhood by subjecting them to emasculation and dependence. ${ }^{42}$

Though white sailors themselves felt enslaved when flogged, it was more concrete and less metaphorical for black sailors. As established by the Army's mutineers, the similarities between maritime corporal punishment and that of slavery provide another motivator for free blacks to rebel on the seas. Since slave ships and plantations all enforced the domination of black bodies through whipping, the punishment was synonymous with bondage, even though merchant and naval sailors of all races were legally free. That the ringleader and the most violent participant of the Cactus revolt were from U.S. slave states suggests they likely drew from the same tradition of violent slave resistance as the occupants of the Creole.

\footnotetext{
41 "Philadelphia, February 1, 1848 the Grand Jury-Fire Rioters-Indictments-Pardon for Mutiny-Gen. Quitman, \&C," The New York Herald, February 2, 1848, https://infoweb-newsbank-com.www.libproxy.wvu.edu/; "Mutiny and Murder on the High Seas," Baltimore Sun, April 18, 1846, Ibid.; "Mutiny and Murder on the High Seas," The Boston Daily Atlas, April 20, 1846, Ibid.; "Serious Mutiny," The Daily Picayune, April 26, 1846, Ibid.; "Mutiny and Murder," Barre Patriot, May 1, 1846, Ibid. Harding later received a pardon in 1848 because he contracted a scrofulous disease.

${ }^{42}$ New York Herald, February 14, 1849, https://access.newspaperarchive.com/ (quotes); Myra C. Glenn, Jack Tar's Story: The Autobiographies and Memoirs of Sailors in Antebellum America (Cambridge: Cambridge University Press, 2010), 112-113.
} 
Yet, the interracial bonds formed within the integrated ships of the nineteenth-century seas often merged the white republican case against flogging with that of the black freedom struggle. During its 1837-1839 voyages, the biracial crew of the whaler Hudson mutinied against corporal punishment. The ringleader, Samuel Maloney, whom ship logs identified as "Negro," and his shipmates conducted a work stoppage against the flogging of another black sailor, William Peterson. To give themselves leverage, they halted their duties at a time when their captain had assigned them to unload over one hundred barrels of oil. In his 1854 account, white mutineer Jacob Hazen referred to Maloney as "old black Sam," illustrating camaraderie. The strike enjoyed success, ending when the captain pledged to cease whipping and rebuked the first mate. Calling on his readers to uphold the manly independence of all mariners regardless of race or place of birth, Hazen's retelling promoted an egalitarian model of masculine citizenship. ${ }^{43}$

Examples also exist of free African-American sailors trying to liberate slaves, utilizing their mobility across the water to advance the emancipation process for others. Two involved bondspeople in Savannah, Georgia. According to the 1825 narrative of William Grimes, nine years earlier, black shipmates of the Boston brig Casket convinced him to leave Savannah by coming aboard while posing as the crewman's master and then hiding in cotton bales during a voyage. In July 1857, Bill Owens, of the Baltimore schooner George McClire, was arrested and whipped for as the press worded it, "attempting to abduct two negro girls from their owners." Black sailors on merchant ships in the postbellum years expanded upon the tradition of seaborne African Americans conducting mutinies in the face of white supremacist violence. A

\footnotetext{
${ }^{43}$ Quoted in Myra C. Glenn, Jack Tar's Story, 142. To evade the punishment he was expecting for joining the mutiny, Hazen later deserted when the ship sailed to Brazil.

${ }^{44}$ William Grimes, Life of William Grimes, the Runaway Slave (New York: self-published, 1825), 51, https://docsouth.unc.edu/neh/grimes25/grimes25.html; Kathryn Grover, The Fugitive's Gibraltar: Escaping Slaves and Abolitionism in New Bedford, Massachusetts (Amherst: University of Massachusetts Press, 2001), 242;

"Attempt to Abduct Slaves," Columbus Daily Sun, July 17, 1857, https://access.newspaperarchive.com/ (quote).
} 
representative case was a June 1871 mutiny on the brig J. L. Bowen. As the ship carried tobacco and stores from New York to Gibraltar and Cadiz, an international group of six black crewmen clashed with members of their exclusively white officer corps. After four peaceful days, tensions emerged due to officers' dissatisfaction with the crew's labors. In response, First Mate J. W. Sleeper, as one press account put it, "used epithets that would arouse the ire of the lowest human mortal. The hot blood of the copper colored seamen was aroused, and they replied in a similar strain." Those present included James Thomas of Portau Prince, William Johnson of Virginia, Peter Anderson of Spain, Emanuel Antoine of the Cape Verde Islands, Thomas Roach of Jamaica, and Mike Antoine of Portugal. When the first mate angrily accused Thomas of performing a task half awake and referred to him as a "damned black-hearted son of a bitch," the latter stood up for himself: "Mr. Sleeper, I came on board this vessel to work just as I have been ordered and am ready to do my duty every time. But I can't be called what (you) called me just now." Sleeper responded with greater animosity, threatening to strike Thomas if he did not resume working. This escalation brought Captain James O. Armsbury and second mate to the scene, who cheered the first officer. A brawl broke out, with reports disagreeing over which side struck first. Every participant armed himself with a heavy pike or piece of wood. Asserting selfdefense, Thomas struck the captain in the head with a capstan bar, splitting open his head and killing him. Another capstan bar beating disabled the first mate, dislocating his shoulder and producing two head wounds. A German ship named the Europa intercepted the Bowen because it had waved its distress signal, arranging for U.S. marshals to arrest the mutineers. The accused ultimately won acquittals, with Johnson and Anderson avoiding prosecution altogether. ${ }^{45}$

\footnotetext{
45 "Mutiny and Murder at New York Yesterday," Boston Daily Advertiser, June 7, 1871, https://infoweb-newsbankcom.www.libproxy.wvu.edu/iw-search/we/; "New York Mutiny at Sea-Captain of a Vessel Killed and other Officers Horribly," The Cincinnati Commercial, June 7, 1871, Ibid.; "The Mutiny on Board Brig J. L. Bowen Further Particulars," Boston Morning Journal, June 7, 1871, Ibid.; "The Bowen Mutiny," Boston Daily Journal,
} 
As with certain black soldier mutinies, the Bowen's became the focus of media outlets with different social agendas. The New York Herald interpreted the mutiny through the lens of racial prejudices. It criticized the captain of the Europa over neglecting to "send a sufficient number of men on board to put the black ruffians in irons." The stunned New York editor reported that the captain gave these "scoundrels," "desperate cutthroats," and "batch of villains" an opportunity to claim another valuable life and/or to escape from law enforcement. The Boston Daily Journal painted the mutiny as a typical scuffle on the level of urban drunken fights, one in which tensions escalated from "the first angry words" to "the terrible blow which sent Captain Armsbury into eternity." Contradicting other reports characterizing the men as "murderouslooking demons," the Boston paper claimed that such coverage proved false and that "in fact a more quiet lot of sailors is seldom seen." It refused to place complete blame on either party. These contrasting press accounts show that black mutinies drove whites to either sensationally tap into white fears of black aggression or calmly address broader problems in U.S. society. ${ }^{46}$ In the late nineteenth century, African-American merchant sailors like those of the Bowen rebelled against white officers to resolve grievances regarding crewmen's material well-being. They perceived that the pillars of their envisioned freedom, devoted to socioeconomic prosperity

June 12, 1871, Ibid., (first quote); "The J. L. Bowen Mutiny," Boston Post, June 9, 1871, Ibid., (second set of quotes); Reports of Cases Relating to Maritime Law: Containing All the Decisions of the Courts of Law and Equity in the United Kingdom, and Selections from the More Important Decisions in the Colonies and the United States: Volume 1, James A. Petrie, eds., (London: H. Cox, 1873), 106-107.

46 "Mutiny and Murder," New York Herald, June 7, 1871, https://infoweb-newsbankcom.www.libproxy.wvu.edu/iw-search/we/ (first and second quotes); “The Bowen Mutiny,” Boston Daily Journal, June 12, 1871, Ibid., (third and fourth quotes). The racial violence of the Reconstruction era continued to rock American merchant ships deeper in the 1870s. In September 1872, for unidentified reasons, the black crew of the bark Jennie Cobb "mutinied and refused to do duty or proceed farther on the voyage." December 1872 saw William Wateley, the black steward of the brigantine Union Star, try to kill the officers and the crew and to destroy the ship following a disagreement with Captain White. He poured acid on the sleeping crew, set the hold aflame, and died of smoke inhalation. The captain saved the crew and extinguished the fire. In November 1874, the white half of a ship crew mutinied on the Neptune when a member of the black half became the boatswain. After the whites beat him, the entire crew was arrested. See "Mutiny," Baltimore Sun, September 27, 1872, Ibid. (quote); "A Remarkable Mutiny," Baltimore Sun, December 23, 1872, Ibid.; “Civil Rights at Sea-a Mutiny," Baltimore Sun, November 12, 1874, Ibid. 
and bodily safety, to be as risk. Blacks considered the threat especially acute because of the ongoing decline of their status in the Merchant Marine. The Atlantic Ocean increasingly was becoming more a source of danger than opportunity.

The place of blacks in the nineteenth-century U.S. Navy derived from their positions in the Merchant Marine, despite contrasts between the two. During the antebellum years, sailors alternated between naval service and merchant work. The typical black sailor endured racial prejudice and discrimination. Unable to comprehend equality, white sailors feared blacks because the latter reminded the former of the common brutalities in maritime and plantation labor. They also worried about the possibility that free blacks sought revenge for slavery and would try to emancipate those still in bondage. Moreover, they subscribed to the antebellum northern cultural notion that saw African Americans as perpetual children and criminals who needed white guidance and control and who possessed inferior mental faculties. Racial equality would, the thinking went, bring whites down to the level of blacks. These views created and maintained a segregated society with separate white and black public facilities and institutions. However, sea life was also one of greater racial equality and integration than life on land. Challenging white sailors' racial ideology, in each armed conflict, wartime realities and pressures forced the Navy to recruit more blacks and to elevate them to a more equal position. ${ }^{47}$ Despite the Navy and Merchant Marine's shared personnel, along with the comparable experiences of naval and commercial seamen, black sailors were far more likely to mutiny in the latter than the former. A probable explanation concerns the Navy's more informal, harsher, and prompt disciplinary practices. As scholars have speculated, these practices generated a servicewide culture that made naval mutinies less attractive and less likely to be documented. Also,

\footnotetext{
${ }^{47}$ David Valuska, The African American in the Union Navy, 1861-1865 (New York: Garland Pub., 1993), 9-17.
} 
given the manpower needs of the Navy in armed conflicts, even racist officers deemed it prudent to downplay their prejudices when interacting with their men. In contrast, merchant mutineers faced the formal civilian court system, attracted more media attention, and served under officers who possessed fewer incentives to avoid sparking racial antagonisms. ${ }^{48}$

It is remarkable that despite protecting a country with a strong white supremacist streak, the United States Navy maintained integrated ships from the time of its eighteenth-century predecessors until the end of the nineteenth century. When they started serving in the late colonial period, black sailors ate, slept, and fought alongside white counterparts and generally enjoyed equal opportunities for promotion. During the American Revolution, like the ground forces, black naval sailors served with both the Royal and Continental Navies. Foreshadowing subsequent black U.S. military service, African Americans formed about ten percent of Patriot naval forces. Blacks enlisted out of both patriotism and a desire to expand their freedom. States offered manumission to enslaved sailors who served in the War for Independence, along with land grants and bounties to any black sailor who did so. In the years following the American Revolution, the U.S. Navy accepted black recruits with few or no conditions. ${ }^{49}$

However, an early threat to the water-based theater of blacks' emancipation process emerged from the young nation's civilian leadership. At different times, Secretary of War Henry Knox, and then the first Secretary of the Navy, Benjamin Stoddert, banned black naval enlistment in 1798. These prohibitions, foreshadowing the Navy's Jim Crow incarnation, occurred in a context where the specter of black sailor mutinies and insurrections, if not in

\footnotetext{
${ }^{48}$ Cornelius J. Lammers, review of Rebellion, Repression, Reinvention: Mutiny in Comparative Perspective, by Jane Hathaway, International Review of Social History Volume 48, Issue 3 (December 2003), 479; Conversation with Ryan Peeks of the Naval History and Heritage Command (NHHC), January 10, 2020.

${ }^{49}$ John Derrell Sherwood, Black Sailor, White Navy: Racial Unrest in the Fleet during the Vietnam War Era (New York: New York University Press, 2007), 1-2; Michael S. Davis, "'Many of Them are Among my Best Men,"” 1120; Lieutenant Denis D. Nelson, The Integration of the Negro into the U.S. Navy (New York: Farrar, Straus and Young, 1951), 1.
} 
concrete form, terrorized white commanders and government officials, likely due to the Haitian Revolution. In June 1798, a frightened Secretary Knox informed President John Adams of the possibility of the French using captured U.S. vessels to unleash tens of thousands of rebellious Caribbean blacks in southern states. The following day, Major Lewis Toussard reported the gathering of a mutiny at quarantined ships near Fort Mifflin, which he commanded. As he noted, between " 250 and 300 negroes" on numerous ships "seem to have adopted between them the most desperate measures to the execution of which they are incited by their owners." Toussard added that these black sailors were "well armed, trained to war" and allegedly advertised plans to launch an attack without regard to either the law or their lives. However, this simmering mutiny proved to be a false alarm, and when the quarantine concluded, the ships' personnel landed without incident. ${ }^{50}$ Rumors of black military rebellion in a climate of acute racial anxieties reemerged in later decades. While whites could point to actual slave insurrections and later, black Army revolts, as evidence, the threat of black sailor mutiny was still a temporally distant threat.

The naval ban on African-American recruits proved illusory as well, in the long and short term. U.S. manpower needs during the 1798-1800 Quasi War with France and the War of 1812 led to the ban's cessation. The Quasi War saw black sailors continue to serve on military vessels, as white officers neglected to enforce their secretaries' rule. This undeclared war featured a rare black sailor mutiny. Yet, rather than a revolt against his officers Moses Armstead led a rebellion against French crewmen who captured him and his shipmen as prisoners aboard their brig Betsies. After liberating the ship, another French naval force seized the Betsies' men, imprisoning Armstead in Puerto Rico. By mutinying against captors instead of his official

\footnotetext{
${ }^{50}$ Michael S. Davis, “'Many of Them are Among my Best Men,"” 22-23; Henry Knox to President John Adams, June 26, 1798, in Naval Documents related to the Quasi War, vol. I (Washington, D.C.: U.S. Government Printing Office, 1935), 139-141; Major Lewis Toussard to the Secretary of War, June 27, 1798, in Ibid., 149.
} 
superiors, Moses Armstead's mutiny can be considered a precursor to that of William Tillman six decades later. In this conflict, as a mid-twentieth-century black officer put it, the Navy maintained its "traditional attitude...toward the use of Negroes," namely, the notion that skin color does not "affect a man's qualification or usefulness."

This attitude was even more acute when American guns shifted their sights to another European adversary in the 1810 s. As was common throughout the nineteenth century, this egalitarian racial attitude in the Navy stemmed more from personnel shortages than from progressive attitudes. The Navy needed manpower of any color, as well as black pilots' knowledge of coastal waters on the Eastern Seaboard, to fight the British. While individual officers expressed racism and physically mistreated certain black sailors who committed offenses in ways that violated the Articles of War, there is no evidence that black sailors received extra harshness from the naval justice system at large during the nineteenth century. Further, commanders praised the abilities and heroism of their black sailors under fire. As Captain Isaac Hull of the USS Constitution proclaimed in 1812, "I never had any better fighters than those niggers." They "fought like devils" and tried to outperform white sailors. Such comments reveal that the Navy's relative racial equality depended on African Americans proving themselves in battle. Throughout U.S. military history, when blacks displayed exceptional combat skills, some white commanders ignored or reconsidered racist views. ${ }^{52}$

Accompanying these practices and sentiments were legislation and policies that further elevated the African-American naval role during and after the War of 1812. A March 1813 Navy

\footnotetext{
${ }^{51}$ Michael S. Davis, "Many of Them are Among my Best Men,"” 23-24; Rayford W. Logan, "The Negro in the Quasi-War, 1798-1800,” Negro History Bulletin 14 (1951): 128-132; Lt. Denis D. Nelson, The Integration of the Negro into the U.S. Navy, 3 (both quotes). For a similar phenomenon involving illegal and fraudulent recruitment of foreign sailors, as well as the challenges of researching them that resemble those of black sailors, see James Valle, Rocks and Shoals, 19.

${ }^{52}$ Lt. Denis D. Nelson, The Integration of the Negro into the U.S. Navy, 2; Stephen Budiansky, Perilous Fight: America's Intrepid War with Britain on the High Seas, 1812-1815 (New York: Vintage Books, 2012), 146 (quote)
} 
Act mandated the recruitment of U.S. citizens, including natural-born "persons of colour," which reopened official black enlistment on the seas. Black sailors utilized this welcoming atmosphere to serve with distinction against British warships on the ocean, rivers, and Great Lakes, making up between six and twenty percent of the Navy during the conflict. Black men relied on the Navy for employment, especially as the branch raised their wages as incentives to serve. The prevalence of African Americans in the seaborne armed forces continued beyond the 1812 conflict despite opposition to it from whites between the top and bottom ranks. Commodore Isaac Chauncey, one of the dissident voices, declared that "I have yet to learn that the Color of the skin, or cut and trimmings of the coat, can affect a man's qualifications or usefulness." However, under pressure from southern politicians, the antebellum Navy instituted quotas for black sailors ranging from five to 4.2 percent. Also, African Americans could leave slavery for an integrated force, but they tended to occupy the lowest ranks. Meanwhile, the Army as of 1815 viewed "soldiers of color as being unfit to associate with (white) American soldiers." 53

Despite racial restrictions, throughout the antebellum years, the U.S. Navy gave African Americans a unique opportunity for social advancement. Banning slaves, recruiting regulations enacted in 1841 proclaimed that "free blacks... were only to be entered by the approbation of the commander of the station." Yet, like the earlier complete ban, liberal recruitment practices on the ground precluded enforcement of the latest regulation. Due to the branch's harsh disciplinary methods, dangerous working conditions, extensive hours, and poor pay and food, its recruitment struggled to such an extent that it needed to enlist any able-bodied recruit. Due to the racial notion that those of African descent possessed immunities for tropical diseases, during the

\footnotetext{
${ }^{53}$ Michael S. Davis, “"Many of Them are Among my Best Men," 25-31; Lt. Denis D. Nelson, The Integration of the Negro into the U.S. Navy, 3; James E. Valle, Rocks \& Shoals, 19-21; Michael S. Davis, "'Many of Them are Among my Best Men,"” 1, 34-35; Michael Cohn and Michael K.H. Platzer, Black Men of the Sea, 122 (quote).
} 
Mexican-American War, the Navy replaced ill whites with blacks in the Gulf of Mexico.

Whether from manpower needs, stereotypes, or sincere acceptance, the U.S. Navy during the first half of the nineteenth century consistently maintained a sizeable Sable Arm. ${ }^{54}$

The Navy's system of relatively more equal race relations persisted deep into the nineteenth century, and likewise blacks continued serving in large numbers throughout the antebellum years. The attitudes of a minority of white commanders, and especially the pragmatic approach of the racist majority to enlist African Americans, demonstrate the frequent importance of biracial alliances to the advancement of the long emancipation process. While full equality never existed in the military's only integrated branch, its relative egalitarianism makes it unsurprising that racially-motivated black sailor mutinies are so difficult to find in the historical record. Black men viewed the Navy as a positive force for their emancipation goals to such an extent that they spent their careers fighting foreign enemies, not superiors under whom they served. With the Navy giving blacks high wages, greater employment opportunities, and a high level of racial equality compared with U.S. society at large, African-American sailors did not see their status as under a great enough threat yet to think about, let alone justify, rebelling against their officers. The Navy's unique system remained in place when the Civil War began.

Despite the tens of thousands of books that have been written on the Civil War, all covering a seemingly endless variety of topics, African-American Union sailors remain one of the most neglected members of the wartime generation. Yet, a handful of historians have built a firm foundation. James McPherson's Ordeal by Fire noted that blacks had "a long history of maritime service" and manned the conflict's first Union warships. Shedding light on the

\footnotetext{
${ }^{54}$ David Valuska, The African American in the Union Navy, 9-17; “Article 512," General Regulations for the Navy and Marine Corps of the United States (Washington: J. and G. S. Gideon, 1841), 164-165 (quote).
} 
cosmopolitan nature of maritime service, David Valuska argues that black sailors in the Union Navy served at an intersection of white, black, and military cultures. ${ }^{55}$

Existing historiography on the Union Navy has proven that Federal forces on the sea were relatively more racially progressive than those on the land and that this status grew out of the practices of the antebellum U.S. Navy. What the scholarship needs to explore further is what the Union Navy's unique place in wartime race relations means for how we should understand the Civil War's emancipationist legacy. The Army's evolving policy from protecting slavery in 1861 , to hiring runaway slaves by 1862 , and finally deciding to attack the institution by 1863 has been well-documented and is central to the "new birth of freedom" school in Civil War historiography. The "dark turn" in Civil War historiography makes us careful not to exaggerate the extent to which African Americans' new freedoms had substance. Subsequent chapters use black soldier mutinies to add to, and complicate, both movements' findings. When one pays greater attention to the war's naval aspect in general and the absence of racially-motivated black sailor mutinies in particular, though, the narrative of the Civil War becomes even more complicated. The recruitment and personnel policies seen in the Navy present us with a segment of American society that had its own, more acute, and older "new birth of freedom."56

As with previous conflicts, in the words of a lieutenant in the 1950s, "military necessity" during the Civil War gave "the Negro the right to do his share of the fighting." Building off of antebellum practices and facing a manpower shortage due to poor white enlistment, the Union

\footnotetext{
55 James McPherson, Ordeal by Fire: The Civil War and Reconstruction (McGraw-Hill Education, 2010); David Valuska, The African American in the Union Navy, 1861-1865. Valuska revises the number of blacks who served in the Union Navy from 29,000 (a quarter of the service) to just under 10,000 (eight percent). Despite this smaller number, they still played a major role because they brought the skills incurred in the antebellum maritime service to the Union Navy.

${ }^{56}$ For representative examples of both scholarship movements, see James McPherson, Battle Cry of Freedom: The Civil War Era (New York: Oxford University Press, 1988); Jim Downs, Sick from Freedom: African-American Illness and Suffering During the Civil War and Reconstruction (New York: Oxford University Press, 2012).
} 
Navy accepted free blacks from the start of the conflict and employed contrabands as early as July 1861. The branch's longtime preexisting practice of recruiting blacks brought in experienced African-American sailors. Federal ships on southern rivers and coasts received a flood of fugitive slaves from boats or nearby land. Matching the predicament facing land forces, these runaway men, women, and children forced the Navy to figure out what to do with them, leading to the employment of able-bodied men for routine chores or transporting the rest to contraband camps and military stations until ships received formal guidance. To be sure, racial tensions simmered on U.S. naval ships. However, due to the relative interracial camaraderie produced in these integrated crews, combined with growing opportunities for African-American promotion, the historical record lacks instances of black Union sailors conducting racially motivated mutinies the way their land-based counterparts did. ${ }^{57}$

To a limited extent, the Union Navy adopted preliminary segregationist practices on vessels that foreshadowed twentieth-century customs. The level of segregation depended on the squadron and ship. It was lowest on the blockade, where any interest in maintaining a color line succumbed to the collective need to chase blockade runners and weather Atlantic storms. In contrast, the Mississippi Squadron's gunboat officers delegated separate shifts to white and black crewmen. Overall, ships whose crews were most susceptible to tense interaction and who had the weakest pragmatic need for prioritizing skill over skin tone tended to be more segregated. Since operations relied on teamwork in close quarters, segregation was impractical and uncommon on most ships and remained so until the Navy restructured itself at the turn of the century. ${ }^{58}$

\footnotetext{
${ }^{57}$ Lt. Denis D. Nelson, The Integration of the Negro into the U.S. Navy, 4 (quote).

${ }^{58}$ Michael J. Bennett, Union Jacks: Yankee Sailors in the Civil War (Chapel Hill: University of North Carolina Press, 2011), 166.
} 
Perhaps a key factor in why no racially-motivated black sailor mutiny was documented during the Civil War is that despite white supremacist hostility, the Union Navy offered benefits that made African-American sailors feel that they had come a long way from bondage. The tendollar wage that the bottom naval ranks earned exceeded the seven dollars USCTs received. While barriers to promotion remained, the Navy never engaged in wage inequality, a common driver of Army mutinies. Contrabands received the daily grog ration, enabling them to join a central part of sailor culture, communal drinking. Officers gradually promoted contraband sailors to skilled positions such as gun crewman and night watchman. Armed duties shattered the notion of whites having a monopoly on martial skills and contradicted the concept of the Civil War being a "white man's war." Whites began to notice that black crewmen enjoyed their new occupations and displayed a high degree of skill, work ethic, and discipline. This performance earned the admiration of white officers, who desired contraband crewmen. Over the course of the war, so many contrabands joined the Union Navy that they reached fifteen percent of the service $(18,000$ men) and ranged between one quarter and a majority on ships. In December 1862, the Navy ended rating restrictions for contrabands, providing them with the same paygrades as whites and free blacks. ${ }^{59}$ Like the first half of the nineteenth century, the seas proved relatively friendlier to the black freedom struggle during the great cataclysm of the mid-century U.S.

Ironically, the infrequency with which the Navy tried black sailors for racially motivated mutinies increases the difficulty of finding their voices in the historical record. Only several newspaper letters from black Union sailors exist. Though a small sample, it nevertheless offers a window into how African Americans viewed their naval service. In these letters, they reported a small degree of prejudice, a lack of quarter from the Rebels, and the liberation of slaves, white

\footnotetext{
${ }^{59}$ Ibid., 166-170.
} 
Unionists, and wounded black soldiers. In May 1864, Drummer George W. Reed asserted with pride that his Potomac Flotilla was a more "perfect terror to the rebel community" than even Ulysses S. Grant's Army forces. While participating in the blockade of coastal Texas as the war was winding down in late May 1865, a gunboat sailor using the alias "Jack Halliards" reflected on a substantial degree of upward mobility between the issuing of the Emancipation Proclamation and the time of writing. ${ }^{60}$ Though they personally were further along in the emancipation progress than those who became soldiers when the war started and never felt that their status was as threatened as some USCTs did as the conflict progressed, black Union sailors understood the gravity of the moment for their people.

While it is difficult to determine which, if any, Union Navy mutiny sought to improve the status of African Americans specifically, plenty of documented instances of another form of racially-motivated rebellion exist, one devoted to maintaining white supremacy. Since the Union Navy offered greater chances for black men to support themselves and their families, and to enjoy the prestige that came with serving in a combat role, much of the racial violence among sailors entailed not black enlistees revolting against white officers, but white enlistees waging violent campaigns against anyone who promoted or symbolized the long emancipation process. The U.S. Navy had always been more welcoming of blacks, but this became even more so amid the emancipationist winds unleashed by the Civil War. Integration may have been tolerable to white sailors, at least with reservations, but the influx of runaway slaves and greater upward mobility for black sailors during the conflict proved too radical for certain white seamen.

\footnotetext{
${ }^{60}$ A Grand Army of Black Men: Letters from African-American Soldiers in the Union Army, 1861-1865, Edwin S. Redkey, ed. (New York: Cambridge University Press, 1992), 269-271; Letter from Drummer George W. Reed, U.S.S. Commodore Reed, May 21, 1864, Christian Recorder, in Ibid., 272-274; Letter from Drummer George W. Reed, U.S.S. Commodore Reed, July 16, 1864, Christian Recorder, in Ibid., 274-275 (quote on 274); Letter from Drummer George W. Reed, U.S.S. Commodore Reed, September 17, 1864, Christian Recorder, in Ibid., 275-276; Letter from "Jack Halliards," U.S. Gunboat Kennebec, May 27, 1865, Weekly Anglo-African, in Ibid., $278-280$.
} 
Racial tensions in the Union Navy originated in antebellum white sailors' fears that they resembled slaves. For them, their status as lowly laborers suffering from drudgery, long hours, and abuse from despotic officers too closely resembled plantation life. Working alongside black sailors and seeing contrabands move up the ranks exacerbated such anxieties. These fears discouraged other whites from joining Union naval forces at the war's outbreak, ironically creating the manpower shortage that encouraged black enlistment. How certain men expressed their sentiments made one naval historian call white Federal sailors "some of the roughest, ill tempered, and violent recruits the Union war effort collected." ${ }^{61}$

Officers were therefore worried over how their men would treat contrabands, which changed as the war progressed. Initially, most white seamen peacefully accepted fugitives coming aboard, giving them food and blue sailor clothing. Yet, white sailors nevertheless complained about the extra labor contrabands gave them and about their large number. Complicating matters further, these same white sailors refused to return contrabands to slavery because they saw firsthand the miseries inherent in slavery and listened sympathetically to horrific accounts of bondage. They learned of experiences—-hunger, fear, and abuse —with which white sailors could relate. However, the main reason why most white sailors accepted new black crewmembers was pragmatic: the latter would transfer labor from the Confederacy to the Union. Orders that white sailors supervise and clean contraband sailors fed into the former's belief in racial superiority. Pranks and harassment owed to the initiation rites all new sailors endured as well as racist beliefs about the black body. Ships gave the runaways the lowest crewman rank, "boy," which conformed with white notions of blacks being perpetual children,

\footnotetext{
${ }^{61}$ Michael J. Bennett, "'Frictions': Shipboard Relations between White Sailors and Contraband Sailors during the American Civil War," Civil War History 47 (June 2001), 118-145 (quote on 122).
} 
limited contraband wages to ten dollars a month (the lowest), and guaranteed contrabands the worst jobs. Thus, white sailors received a version of David Roediger's "wages of whiteness."62 The leveling from upward black mobility caused white sailors not to reconsider their racist beliefs, but instead to experience an increase in their anxiety as working-class Americans struggling to reach the republican ideal of free, independent men. Before the war, othering blacks and slaves enabled white sailors to avoid being seen as "wage slaves." Also, while the Navy had banned flogging in 1850, disciplinary punishments of the violent, degrading sort persisted. These included the "irons," the shackling of one's arms and feet, which spawned images of slavery. White sailors realized that they now closely resembled contraband sailors: young, impoverished, uneducated, and unskilled. Civilians taunted white sailors, accusing them of being black, enslaved, imprisoned, and emasculated. White sailors longed for the day when they became their own master, reaching the socioeconomic independence lionized in republican ideology. Unlike the Army, more and more whites in the Navy opposed the Union's escalating emancipationist war effort beginning in 1863. After the issuing of the Preliminary Emancipation Proclamation in September 1862, "frictions"—exchanges consisting of bickering and violence —increased. With emancipation fostering a sense of pride among black sailors, whites condemned any behavior indicative of social equality. According to whites bitter over emancipation, officers gave blacks preferential treatment, blacks now enjoyed better conditions on ships, and reverse racism rather than merit explained black sailors' upward mobility. Following the full implementation of the Emancipation Proclamation, white sailors on the blockade and Mississippi squadrons engaged in "corrections," or rites of passage consisting of intimidation, humiliation, and forceful acts aiming to reestablish white supremacy. When contrabands ate out of mess pans, white sailors compelled

\footnotetext{
${ }^{62}$ Ibid.; David Roediger, The Wages of Whiteness: Race and the Making of the American Working Class (Verso:
} 1991). 
them to carry heavy objects while bound with a rope for several hours. White sailors took pleasure in watching minstrel shows, conjuring up homicidal fantasies, and observing officers tie up contraband sailors charged with disobedience by the thumbs. ${ }^{63}$

When blacks refused to heed the above warnings, whites violently attacked them. As a black sailor walked through a block of white sailors dancing a quadrille and stepped on James Collins' foot with an uncertain intent, they "gave him a good biff... he got a pretty good tossing all around." Murderous cases exist of white sailors shooting blacks, crushing their skulls, or throwing them overboard. White Landsman John Gavin, who inflicted severe facial injuries to contraband Leri Lee, told his superiors in 1863 that “you can’t expect justice from a set of damned nigger lovers." With race relations deteriorating, and some blacks deserting in response to this environment, officers hung white sailors who killed contrabands. By 1864 and 1865, these conditions reached such a level that race riots hit ships. Episodes on individual ships foreshadowed the postbellum racial violence hitting northern and southern cities. ${ }^{64}$

Escalating racial tensions occasionally broke out into mutiny. In October 1862, the Western World became an early example. As the ship sat near Doboy Sound, Georgia, the mutineers gathered on the spar deck refused to serve under the current Acting Master Samuel B. Gregory or "any tyrannical commander" any longer because of pro-contraband policies, desiring to replace him with Executive Officer B. G. Pettingell. Pettingell committed actions on the steamer Western World which also led to his prosecution for violating the mutinous sections of naval regulations. Filling in for Gregory as acting master, Pettingell listened to the mutineers

\footnotetext{
${ }^{63}$ Michael J. Bennett, "'Frictions."”

${ }^{64}$ First quote in Michael J. Bennett, "“Frictions"”; Proceedings of a Naval General Court-martial (NGCM), Trial of Landsman John Cannon, RG 125, 3405, NARA; Proceedings of a NGCM, Trial of Landsman John Gavin, RG 125 , 3235, NARA (second quote); Oneida Ship's Diary, 1862-1863, November 5, 1863, Southern Historical Collection, Wilson Library, University of North Carolina at Chapel Hill. Bennet suggests that the reasons for this violence partially owed to misgivings with naval service in general, especially its cramped conditions and long periods of work without a break; black sailors served as a fitting scapegoat.
} 
inform him of their intention to no longer obey the commands of the former. When Gregory returned later that day, Pettingell and several other officers repeatedly refused orders to arm themselves and help the commander suppress the rebellion until threatened with punishment. ${ }^{65}$

The trigger for the Western World mutiny was "a difficulty" that had broken out between white crewman Michael Whaley and a contraband named Jacob. While the sailors were implementing an order to rub the deck with sour oranges, someone threw a portion of the fruit at Jacob, on which he blamed Whaley, who in turn pled his innocence. Jacob threatened to report Whaley to the captain if he threw another orange at him, which prompted Whaley to strike Jacob with such force that he bled from below his eye. Whaley continued to deny throwing the orange, but he admitted to Gregory that he not only struck Jacob, but would do so to any "negro...when he replied to him." Thus, Jacob incurred wrath for daring to talk back to a white man. Gregory then called on the master at arms to place Whaley in double irons. Escalating the situation, Whaley "threatened to throw me upon the deck, and tried to do it." However, Gregory restrained the belligerent until the master at arms arrived to arrest him. The acting master proceeded to finish gathering fuel for the ship's boilers ashore. ${ }^{66}$

Upon returning, he encountered a mutinous assembly. Boatswain's Mate Robert Lewis informed Gregory of their demand "to no longer serve under my tyrannical command." When the men denied that they sought to conduct a mutiny, Gregory notified them that their use of verbs like "will" and "won't" brought their actions to the level of the crime. They rejected his subsequent order to return to duty, with Lewis, Master at Arms George Bell, and Gunner's Mate John Deverence proving themselves the ringleaders. Regarding their preference for Pettingell, he informed the sailors that they did not possess a choice in who commanded them as captain. They

\footnotetext{
${ }^{65}$ Proceedings of a NGCM, Trial of Charles Cheesbro, RG 125, 3177, NARA.
}

66 Ibid. 
objected to how he "loved a nigger better than a white man, and would believe a nigger quicker than I would a white man." The acting master replied that he was a Democrat and as such endorsed state's rights and white supremacy, but needed to follow naval regulations if a white man assaulted a black man or vice versa. He emphasized that he put Whaley in irons not because of the altercation with Jacob, but because the white crewman defied a superior. Meanwhile, Jacob was also in irons, and both would continue to do so until they "agreed to do their duty afterwards." This explanation also seemed to appease the crewmen, who contended that "they had been deceived or mistaken" regarding Gregory's leadership choices. For compelling Acting Master Gregory to put down the work stoppage more unilaterally, the Navy found Pettingell guilty on all counts, sentencing him to a six-month imprisonment and subsequent discharge. ${ }^{67}$

The above white supremacist mutiny highlights various aspects of Union Navy race relations and helps explain the dearth of black naval sailor mutinies. By the fall of 1862, the white sailors of the Western World had become so disaffected with their government's recent move to couple abolition with preservation of the Union that they collectively refused to do their duty and attempted to replace their commander with one who more closely reflected their racial views. Despite this bigotry, however, contrabands like Jacob could expect the military justice system to prosecute and convict those who mistreated them, discouraging them from conducting their own revolts. Even when black sailors served under racist commanders, they generally enjoyed the protection of their equality under military law. In contrast, Union Army officers repeatedly made the black rank-and-file feel so expendable and disrespected that a richly documented record of USCT mutinies exists. In the Civil War-era U.S. military, on land and sea,

\footnotetext{
${ }^{67}$ Proceedings of a NGCM, Trial of B.G. Pettingell, RG 125, 3173, NARA (quotes). It is unclear if the mutineers themselves or other disobedient officers were court-martialed.
} 
African Americans could expect a greater commitment to rule of law and due process than in society generally. Such was a welcome sign that the emancipation process was moving forward.

Despite racial tensions on ships, official naval policy mandated equal treatment for all enlisted men when enforcing military regulations. The Navy judged each individual according to merit and rank. Through equal treatment, the Navy could not always root out racism by white sailors, but it inadvertently improved African-American lives by focusing on efficiency. When a drunk white coxswain murdered a contraband in November 1863 and received a lenient sentence from the Army, the Navy objected. Commodore Bell blamed the sentence for incentivizing a subsequent episode in which a white crew member threatened another contraband with an iron bar. In cases where white crewmen killed black civilians, naval officials tried the accused and permitted black witnesses to testify ${ }^{68}$ The military justice systems of both branches gave blacks an unprecedented degree of equality, but that of the Navy proves less dramatic of a change when considering the relative egalitarianism characterizing nineteenth-century black maritime history.

Another area in which African-American sailors enjoyed equality, removing a central motivator for mutiny, concerned demobilization following Confederate defeat. Although African Americans enlisted in the seaborne forces much earlier than they could in land units, this was not the only reason why black sailors, unlike their Army counterparts, could return to civilian life once the Confederacy collapsed. In June of 1865 , following the war's conclusion, the Navy released a large number of sailors, both white and black, whose terms expired before January 1866. By May 1865, numerous contrabands successfully applied for discharges in order to take care of their families. A number qualified for either free transportation back home or a three-

\footnotetext{
${ }^{68}$ Ibid., 67-79. U.S. naval forces not only accepted contrabands, but also complied with an 1862 treaty banning the international slave trade, which placed freed slaves into five-year "free" labor contracts along with housing in the West Indies. These contracts resembled the federal government's experiments with free labor on southern plantations during Reconstruction.
} 
cent-per-mile allowance. The Navy discharged sailors en masse by September $1865 .{ }^{69}$ The much later discharges that African Americans in the immediate postbellum Army drove one of the largest waves of black mutinies in U.S. history. ${ }^{70}$

The socio-cultural impact of serving in integrated crews might also explain why raciallymotivated black mutinies likely did not occur in the Union Navy. As Civil War naval scholars like David Valuska reveal, while enlisted soldiers in all-black segregated regiments formed bonds with each other, black sailors faced constant pressure to conform to white culture from their Caucasian shipmates. In contrast, enough white sailors formed the bonds necessary to conduct white supremacist rebellions because they comprised a majority on most ships. ${ }^{71}$

During the Civil War, black sailors aboard Confederate vessels were more likely to conduct racially motivated mutinies in the form of slave revolts than their Union counterparts. Robert Smalls led the most famous example of this type of resistance against white supremacy. In the early morning hours of May 13,1862, with the white officers ashore at Charleston harbor, he and the seven other black crewmen of the C.S. steamer Planter guided their family members aboard and hijacked the ship. Smalls, the ship's pilot, sailed the vessel past a Confederate sentinel and with a white flag waving, to a Union blockade force. Once there, Smalls delivered the ship, with its supplies, weapons, and ammunition, to the Federals. As Smalls proclaimed, while serving the Confederate Navy as a pilot, "it occurred to me that I could not only secure my own freedom, but that of numbers of my comrades in arms, and moreover, I thought the Planter might be of some use to Uncle Abe." For conducting such a daring operation in service of both their emancipation and the Union war effort, the eight sailors received a financial reward. Smalls

\footnotetext{
${ }^{69}$ Ibid., 101-103.

${ }^{70}$ For this wave, see chapter 3.

${ }^{71}$ David Valuska, The African American in the Union Navy.
} 
continued this dual effort as a U.S. naval pilot, utilizing his knowledge of coastal and interior waterways. This feat combined slave revolt, sailor mutiny, and a southern bondsperson's flight to the free North. When Smalls and his companions successfully took control of a ship, they accomplished what the most overt naval and merchant sailor mutineers traditionally dreamed. After liberating himself and assisting the wartime collapse of slavery, Smalls moved on to additional stages of the emancipation process during Reconstruction and afterward. He pursued an education and starting in 1876, served in the South Carolina legislature for five terms. ${ }^{72}$

To make sense of the convoluted directions the long emancipation process took on water during the nineteenth century in general and Civil War era in particular, slave revolts like those of Robert Smalls should be examined alongside free black northerner William Tillman's own battle against the Confederacy's proslavery mission. Rather than allow themselves to stay at, or plunge to, the level of a dependent individual with no control over their destiny, Smalls and Tillman risked their safety fighting to gain or regain liberty. While non-enslaved black sailors rarely rose up, if they found themselves losing their freedom entirely, they knew that armed resistance would be necessary to preserve or gain their liberty. The trajectories of Robert Smalls and William Tillman — both men receiving financial rewards for boldly emancipating or reemancipating themselves and aiding the Union cause, and Smalls serving in politics in the 1870s - outline the Civil War and Reconstruction stage of the emancipation process in microcosms. Through mutinies against the Confederate Navy and its privateer auxiliaries, African Americans paved the way for greater economic, educational, and political rights. Mirroring antebellum predecessors, these slave revolts against the Rebel naval forces indicate

\footnotetext{
${ }^{72}$ Edward A. Miller, Jr., Gullah Statesman: Robert Smalls from Slavery to Congress, 1839-1915 (Columbia: University of South Carolina Press, 1995), 1-7; Michael S. Davis, "'Many of Them are Among my Best Men,"” 42; Quote in W.E.B. Du Bois, Black Reconstruction in America, 1860-1880 (New York: The Free Press, 1935), 95; F. G. Ravenel to R. S. Ripley, May 13, 1862, O.R.N., Ser. 1, Vol. 12, 825-826.
} 
that African Americans were more likely to engage in wet mutinies when they were further behind in the emancipation process than blacks serving on integrated Union ships.

Despite the small odds that any U.S. naval vessel would become the site of a proemancipation rebellion throughout the nineteenth century, the early Reconstruction period almost brought a wet mutiny to accompany the dry ones then erupting in southern communities. In June 1866, black sailors aboard the U.S.S. Vermont allegedly plotted a mutiny against their officers, followed by a land raid with African-American civilians against houses near the Brooklyn Navy Yard. They planned to murder their officers and all persons who resisted them before seizing a boat in the naval yard and escaping. When First Lieutenant Mitchell learned of it, he informed his superior, who in turn ordered the searching of all two hundred black sailors aboard. According to press coverage, the search confirmed the existence of the conspiracy. Some alleged conspirators planned to use "badges, silver stars and other insignia." The white officers arrested six ringleaders and confined them with irons. As a New York Herald article put it, "the whole matter seems to be the idea of some hair-brained fellow, who, if he had the least idea of the difficulties the mutineers would have to encounter, would never have put it on foot." 73

The above case, as well as the Army episodes discussed in other chapters, perpetuated the specter of black-on-white violence more commonly associated with the 1865 Christmas Insurrection scare and rumored and actual antebellum slave revolts. With African Americans poised to gain an unprecedented degree of political, socioeconomic, and cultural autonomy out of the ashes of bondage and the Reconstruction of the ex-Confederacy, whites feared a postbellum, post-slavery version of prewar mutinies like the Creole. They worried over the

\footnotetext{
73 "Attempted Mutiny Trouble on Board the United States Receiving Ship Vermont," New York Herald, June 17, 1866. The purpose of this proposed bloodshed, and the ultimate fate of the conspirators, are not clear from this thin record.
} 
spilling of white blood on land as well as sea. If the Vermont plot was as real as whites feared, it foreshadowed the retaliatory mutinies, riots, and rampages African-American soldiers and sailors later inflicted against the defenders and remnants of Jim Crow.

Despite the scarcity of pro-emancipation mutinies on nineteenth-century U.S. military vessels, many sailors, regardless of racial background, framed their insubordination and rebellions as actions promoting their own liberation from the brutal conditions of naval service. These sea-borne mutinies, comprised of all-white and biracial participants, along with the common motivators behind these mutinies, provide insights into how a mutiny in the military's sole integrated branch could indirectly affect the long emancipation. Such mutinies either promoted the black freedom struggle or demonstrated that the degree of inter-racial solidarity that existed on ships made the need for an emancipationist mutiny less necessary.

Before and during the Civil War, numerous parallels existed between racially motivated black soldier mutinies and acts of resistance involving U.S. sailors in general. Union sailors, ninety-percent of whom were white, staunchly defended their personal autonomy against sadistic and overbearing officers in much the same way that black soldiers did so. From their perspective, the 1862 regulation banning alcohol violated the terms of their enlistment, a view not dissimilar from how black servicemen perceived racial discrimination. As an 1865 naval officers' manual noted, "The sailor is the most profound stickler among men for what he conceives to be his rights...he will fight to the bitter end for them," which were "divine and human" in origin. ${ }^{74}$

\footnotetext{
${ }^{74}$ Michael J. Bennett, Union Jacks, 114. As scholars of the Civil War naval forces and naval court-martial records reveal in particular, alcohol consumption proved to be the greatest driver of disciplinary problems in the branch. Intoxication's erosion of motor ability and inhibitions caused the likelihood of sailors to act disorderly, commit illegal vices, and defy superiors to skyrocket. In the summer of 1862, Congress enacted regulations aimed at curbing drunkenness in on ship crews called the Reform Act. This law controversially prohibited liquor on ships beginning September 1. The alcohol ban sparked protests and condemnations from Union sailors, especially in the North Atlantic Blockading Squadron, such as one who called the measure "an act of tyranny" and the men of the Brooklyn, who compelled their captain to issue a grog ration to avoid a riot. Fanning these flames of grievances was officers' zealous enforcement of the Reform Act, cracking down on all behavior they found objectionable. Bitter over being
} 
Labor regimes consisting of rigid discipline and despotic leadership tend to make those working under them most conscious of their rights and liberties, since these individuals know the most about the limits and enforcement of these freedoms.

This naval commitment to protecting one's terms of enlistment and perceived human rights led to at least one notable confrontation in the early national period. In the spring of 1804 , Seaman Robert Quinn of the frigate President penned a letter to his captain listing many grievances. His complaints centered on seventeen-hour duties and denial of warm clothing. According to Quinn, these abuses from his ship's commanders were “enough to turn any man's heart to wickedness." He hoped to eventually "get redress" from this "tyranny," which had turned him and his fellow sailors into "unhappy slaves." Mirroring republican and martial masculine discourse that fueled the Patriot cause of the American Revolution and centuries of slave revolts, Quinn concluded that "death is always superior to slavery." His Captain Samuel Barron treated the letter as a threat "calculated to incite mutiny," and the resulting court-martial made an example out of him. The judges ordered the shaving of his head and eyebrows, the branding of the word "mutiny" on his forehead, the wearing of a white cap identifying him as a mutineer with large capital letters, three hundred lashes, and the drumming of the convict on shore. ${ }^{75}$ Foreshadowing the arguments of future generations of formerly enslaved Army mutineers regarding the cruel nature of their own service, many sailors characterized the brutal life at sea as contrary to the freedom to which Americans were entitled. While whites like Quinn invoked "slavery" in the abstract, referring to a man's dependence on another that prevented him

subjected to constant policing of their personal behavior, Union sailors engaged in subtle forms of resistanceillegally drinking, dragging their feet, mocking, grumbling, laughing, and growling at officers - all while trying to avoid overt acts that would lead to a court-martial and being placed in irons. See Ibid., 109-115.

${ }^{75}$ Robert Quinn to Commodore Barron, June 19, 1804, in Naval Documents Related to the United States Wars with the Barbary Powers, Vol. 4 (Washington, D.C.: Government Printing Office, 1942), 203 (quotes); Proceedings of a NGCM, Trial of Robert Quinn, RG 125, 24, NARA. 
from serving his family and country free from self-interest, in African-American eyes, mistreatment conjured up the concrete bodily domination and dehumanization of chattel slavery. As labor strikes became a hallmark of American industrial capitalism in the early to midnineteenth century, sailors of unclear racial backgrounds mutinied because of disputes over terms of service, pay, and discipline. In 1852, men from the St. Lawrence harassed officers, demanding discharges because they had completed a long voyage despite having not completed their threeyear terms. Officers blamed the disaffection on the recent abolition of flogging as punishment, which they thought encouraged troublemakers to erode the Navy's discipline. In 1839, the crew of the Independence "refused to do duty" and developed "a great state of excitement and insubordination" because of the practice of officers arbitrarily lengthening terms of service. On the Cincinnati during the Civil War, shipmates approached their officers to demand payment of wages due fourteen months previous. When their superiors refused, they dropped their mops. Since commanders stereotyped sailors as men who wasted money on alcohol and gambling, the Navy sometimes failed to pay monthly wages in a regular fashion. Struggling to support their needy families, sailors felt swindled. These sailors also resented the Federal practice of indefinitely extending three-year terms after expiration. This form of "impressment," as they deemed it, was "contrary to the constitution and to the laws of the United States." Similarly, some USCTs stacked their arms and refused payment rather than continue accepting tardy and unequal wages, and likewise refused to perform their duties over a dispute regarding their own terms of service. Comparable to USCT outbursts against arbitrary punishments for minor or nonexistent offenses were the Brooklyn's crew. In May 1863, this group yelled and threw chain chalk at a master's mate for arresting a shipmate on false and unclear pretenses, deeming it a "great injustice." Further, just as many USCT officers viewed their men as racially inferior, 
superiors on Union vessels tended to look down on the average rank-and-file sailor in such terms as "scum" and drunken "Jackys." Intensifying class tensions on ships was a key driver of both the harsh discipline and the resulting mutinous behavior on U.S. ships from 1862 onward. ${ }^{76}$

Shortly after the Civil War, a sailor conducted his own mutiny in defense of his perceived right to both determine his leisure time and avoid physical abuse. In August 1865, Boatswain's Mate William Williams of the U.S.S. Yucca committed three offenses: staying absent longer than his designated leave, disobeying orders to come aboard, and engaging in mutinous conduct by threatening to stab his superiors and striking one who tried putting him in irons. The officers finally put him in custody after an intense struggle. His language included "damned son of a bitch of a downeaster" and denials of the officers' authority to shackle him. For his mutiny, Williams received a five-year prison sentence. Given the popularity of this boatswain's name, it is difficult to determine which among the many men who shared the name conducted this mutiny. Most in the enlistment records were white, but two of them were of African descent. ${ }^{77}$

The imperfect demographic information provides a range of possible meanings for these episodes. If the mutinies had biracial participants, one can interpret them as an extension of the nineteenth-century Navy's relatively more egalitarian nature. If so, these incidents join the Readjusters and Populists on the list of biracial social and political movements that overcame racial divisions to focus on common socioeconomic grievances. However, if most mutinous crews were mainly drawn from the white segment of the service, then sailor uprisings and black

\footnotetext{
76 James E. Valle, Rocks \& Shoals, 121, 124-125, 127; Michael J. Bennett, Union Jacks, 119-124, (first quote on 120, second quote on 122); Proceedings of a NGCM, Trial of John Simpson, RG 125, 3177, NARA. For USCTs, see chapters 2 and 3.

${ }^{77}$ Proceedings of a NGCM, Trial of William Williams, RG 125, 4144, NARA; "Web: US, African American Civil War Sailor Index, 1861-1865," https://www.ancestry.com/search/collections/9748/; "Naval Enlistment Weekly Returns, 1855-1891," www.fold3.com. Respectively, a sample of sailors with the name William Williams have the following demographic characteristics: fair, dark, florid, light, mulatto, Negro; New York, Baltimore, Boston, Detroit, Louisville, South Carolina, Alexandria, Philadelphia; mariner, seaman, waiter, mariner.
} 
soldier rebellions emerged out of different traditions of resistance and understandings of liberty.

All mutineers to some extent observed violations of citizenship and human rights; black mutinies in particular had an added layer of past and present racial troubles and traumas. ${ }^{78}$

When African American sailors do appear in the court-martial records for mutinous activity, it is for non-racial reasons, such as the poor discipline resulting from alcoholic consumption. The naval court-martial records offer seemingly endless examples of these types of episodes. A New York-born cook when he enlisted in Boston in June 1862, the mixed-race, twenty-two-year-old Landsman William Henry Norton of the U.S. steamer South Carolina was charged with "being present at mutiny without making any effort to suppress it" and disobeying orders on the evening of November 23, 1863. The officer of the deck, J. W. Magune, had placed irons on white Seaman Nicholas Johnson for acting disorderly and loud and striking Acting Ensign Bourne. Exclaiming "damn him [Magune], that'll never do" and leading the pack, Norton and between five and ten others rushed to the scene to release Johnson, who had called for assistance. When Acting Master-at-Arms F. F. Banny commanded Norton to submit to being placed in his own irons, he retreated to a gun room and threatened to stab this officer. Thus, officers contended that the mulatto landsman "did aid and abet" an "effort to suppress this (mutinous conduct)," violating Article 3, Section 1 of naval regulations. Meanwhile, the other mutineers obeyed the orders, standing down. With great effort, the officers finally constrained Seaman Johnson and Landsman Norton. In Norton's court-martial defense, he contended that no mutiny ever occurred and tried to instill reasonable doubt by claiming that all landsmen carry knives and noting equivocations in witness testimony. The judges found him guilty of "being present at and inciting insubordination," sentencing him to double irons and solitary confinement

\footnotetext{
${ }^{78}$ For a seventeenth-century interracial naval mutiny, see Marcus Rediker, Many-Headed Hydra, 130-131.
} 
for thirty days along with pay forfeitures and a reduction in rank. The judges ultimately disagreed with the characterization of his actions as "mutinous." 79

There are at least two ways to frame the South Carolina mutiny. In this drunken brawl, rich statements presenting deep lessons about American social and power relations are absent. As such, the mutiny aboard the ship confirms that in the nineteenth century, black sailors tended to revolt for the same, non-racial reasons as white counterparts. On the other hand, that Norton tried to spare Johnson from discipline at a time when officers were cracking down on vices like drunkenness, one can also place Norton's involvement in the mutiny in another light: the efforts of a biracial alliance of working-class sailors to resist their affluent officers' excessive regulations of personal behavior. The latter interpretation holds when comparing Norton's actions to USCTs attempting to free their land-based comrades from custody.

Though its specific details are a source of scholarly and contemporary controversy, the Somers Affair of 1842 offers the best example of an inter-racial naval revolt in the nineteenth century. According to one viewpoint, the brig became the site of an aborted mutiny of between a dozen and twenty U.S. sailors, who planned to kill their officers and turn the ship into a pirate vessel that would plunder and pillage merchant ship crews across the Atlantic. Another perspective counters that the ship's paranoid captain made a farfetched conclusion about the aims of the defendants, and that in prosecuting them, the Navy violated their due process rights.

Either way, on the night of November 25, while the brig was sailing back to the U.S. from Africa, Purser's Steward James W. Wales learned of the alleged plot, which officers moved to abort. A subsequent inspection located a document written in Greek laying out this conspiracy

\footnotetext{
${ }^{79}$ Proceedings of a NGCM, Trial of William Henry Norton, RG 125, 3444, NARA (first quote); William H. Norton Record, "All Web: US, African American Civil War Sailor Index, 1861-1865 Results," https://www.ancestry.com/search/collections/webasm-9748/?count=50\&f-F0005868=South+Carolina\&f-

F0005868_x=1; Proceedings of a NGCM, Trial of Nicholas Johnson, RG 125, 3433, NARA (remainder of quotes).
} 
and the names of twenty others. Convinced that a mutiny was brewing, officers placed the would-be mutiny's instigators, all of whom were white- Midshipman Philip Spencer, along with Boatswain Samuel Cromwell and Seaman Elisha Small—into custody before anything occurred. Concluding that "the safety, our lives and honor to the flag entrusted to our charge, requires that the prisoners be put to death, as the course best calculated to make a salutary impression upon the rest of the crew," the ship's commanders hung the three ringleaders on December 1. A subsequent court of inquiry endorsed this swift act of punishment on the grounds that the commanders were in immediate danger and keeping the ringleaders alive made it probable that other mutineers would free them. Furthermore, a court-martial in early 1843 acquitted Commander Alexander Mackenzie of charges incurred for carrying out the executions. Among the list of other alleged conspirators were two African Americans: Henry Waltham, the wardroom steward, and Edward Gallia, the steerage cook. Waltham later received repeated whippings for stealing alcohol and for having been associated with the Somers mutineers. Besides Walham's experiences, the Navy never formally punished the other suspects. ${ }^{80}$ Regardless of its true nature, the Somers Affair offers substantive lessons for AfricanAmerican naval service and the topic of wet mutiny. If the alleged plot was legitimate, it provides another example of black sailors seeking money and greater power and thereby trying

\footnotetext{
${ }^{80}$ James E. Valle, Rocks \& Shoals, 108-110; "Further Particulars of the Tragedy on board the Somers," Newport Mercury, December 24, 1842, https://access.newspaperarchive.com/; Frederic Franklyn Van de Water, The Captain Called it Mutiny (New York: Ives Washburn, 1954), https://babel.hathitrust.org/cgi/pt?id=uva.35007002453854\&view=1up\&seq=15; Case of the Somers' Mutiny: Defence (sic) of Alexander Slidell Mackenzie, Commander of the U.S. Brig Somers, Before the Court Martial Held at the Navy Yard, Brooklyn (New York: Tribune Office, 160 Nassau Street, 1843); "The Mutiny On Board the U.S. Brig Somers," New York Herald, December 20, 1842, https://access.newspaperarchive.com/; Quote on "ZB (Personnel) Files in the Navy Department Library » ZB Files $-\mathrm{S} \gg$ Spencer, Philip,” https://www.history.navy.mil/content/history/nhhc/research/library/research-guides/z-files/zb-files/zb-filess/spencer-philip.html. A number of factors lend support to either interpretation: Spencer had a poor disciplinary record; officers noticed a decline in morale as it sailed back from Africa to New York; Mackenzie had a reputation for having an active imagination; and damage to the vessel's spar, sails, topmast, and rigging in the last week of November suggested someone had committed a degree of sabotage. Valle takes a nuanced perspective combining elements of the two main interpretations.
} 
to end oppression by any means. The menial labor Waltham and Gallia performed could have fostered a desire for an extra-legal shortcut to a life in which they had more personal autonomy and greater access to affluence. As scholars of the subject have documented, the phenomenon of piracy in the Atlantic world subverted social hierarchies. On pirate ships, men of multiple races, ethnicities, and cultures elected their officers, limited the power of their captain, divided up loot equitably, and generally eliminated the rigid disciplinary regimes seen on merchant and naval vessels. Thus, the pirate ship was the most egalitarian version of the sea's levelling tendencies. ${ }^{81}$ If something else took place or if mere paranoia ruled on the Somers, the affair sheds light on the fear among maritime personnel that the isolation and intra-crew resentments that characterize life on the sea could breed violence from those of any socio-cultural group.

Finally, the ways in which the Somers' commanders quelled the uprising - preemptively, swiftly, and without formally charging anyone with mutiny-provide two likely reasons for the rarity of black naval mutinies in the historical record beyond the contentment produced by the branch's greater degree of racial equality. First, a number of such incidents could have occurred, but in the absence of sensationalist headlines and courts-martial, relevant personnel simply never wrote about it. Secondly, the lack of due process given to Spencer, Cromwell, and Small might have discouraged some frustrated African-American sailors from even planning minor acts that their white superiors could also interpret as worthy of an extra-legal death penalty.

A range of incidents during the Civil War did not reach the level of mutiny, but nevertheless form part of a campaign by black sailors and white allies to advance the cause of emancipation. In doing so, white supremacy's legions expressed alarm over the specter of black insurrection during a period when bondage was buckling under the strain of armed conflict and

\footnotetext{
${ }^{81}$ Peter Linebaugh and Marcus Rediker, Many-Headed Hydra, 162-163.
} 
social displacement. In September 1862, the Union Navy censured and dismissed Master's Mate Sidney McAdam from a gunboat flotilla for kidnapping African Americans within Union Army lines and selling them into slavery. Commodore C. H. Davis condemned the offense as "scandalous and dishonorable conduct." Black Federal naval personnel could generally count on superiors to protect the freed status of former slaves, which was essential for the emancipation process to have forward momentum. ${ }^{82}$

This non-mutinous campaign hit Rebel ships as well. African-American desertions from the Confederate Navy, like their Army counterparts, connect military emancipation with the antebellum fugitive slave phenomenon. In August 1861, two bondspeople on the C.S.S. Sumter, including the commander's personal servant, fled while the ship was docked at the South American city of Paramaribo. Exposing the pillar of white supremacy that black resistance targeted in the Rebel Navy, the above commander declared that "the negro is not only bound to service on board this ship but is also valuable private property," and upon the Confederate government reclaiming him, it does so according to both principles. When bondspeople fled, they often offered information on the enemy to Union ships, which in turn granted them protection and rations, just as land-based contrabands did. These incidents demonstrated that whenever African Americans rebelled against a white supremacist system, they did not merely respond to local circumstances but also acted within the broader social, political, economic, and legal order underlying and shaping these circumstances. Both the black resisters and white oppressors recognized the deeper meaning attached to bondspeople's desertions. Echoing Frederick Douglass' descriptions of his antebellum flight to freedom, these actions constituted a black man's theft of his body from the master who owned it. Yet, when an enslaved person fled

${ }^{82}$ C. H. Davis to Sidney McAdam, September 5, 1862, Official Records of the Union and Confederate Navies, Ser. 1, Vol. 23 (Washington, D.C.: Government Printing Office, 1894-1922), 335 (hereafter O.R.N.). 
from the Confederate military, he or she was not just stealing themselves from an individual master, but also a slaveholder's republic. ${ }^{83}$

In an unprecedented change of course, the opportunities the Navy gave African Americans on the seas eroded by century's end. In the postbellum years, prospective and actual African-American sailors faced the same minimal restrictions as they did since the early republic, but signs of a different order were emerging. However, by the late-nineteenth-century, the U.S. Navy gradually became less welcoming to its black sailors, paving the way for emancipationist-type mutinies to become far more likely in the twentieth century. As Michael Bennett notes, "After the Civil War, the navy abandoned its policy of an integrated navy." 84 Despite the general accuracy of this statement, a fresh look at the evidence shows that the segregation of the Navy developed more gradually, not gaining much steam until the 1890s and 1900s. The white backlash towards the Navy's contraband policy was only the first step in a long trend. Blacks' percentage in the branch dropped from a peak of one-fifth during the Civil War to thirteen percent in 1870 . With the service still prioritizing skill and intelligence, blacks made up between ten and fourteen percent of naval enlistees in the last three decades of the century. Although they mostly served as landsmen, cooks, and stewards, some became seamen and specialists (firemen, storekeepers, carpenters, water tenders, and oilers). Petty officer was still the highest rank African-American sailors could hope to attain; of the six black men appointed to the Naval Academy between 1872 and 1900, only three attended, but did not graduate. To be

\footnotetext{
${ }^{83}$ Extracts from notes on the C.S.S. Shenandoah, February 1865, O.R.N., Series 1, Vol. 3, 811-813; Raphael Semmes to Mr. Van Lansberge, August 30, 1861, O.R.N., Series 1, Vol. 1, 627; Raphael Semmes to J. W. Gefken, August 31, 1861, Ibid., 628 (quote); O. S. Glisson to Silas H. Stringham, July 15, 1861, O.R.N., Ser. 1, Vol. 6, 9; O. S. Glisson to Silas H. Stringham, August 20, 1861, Ibid., 95; O. S. Glisson to Silas H. Stringham, August 22, 1861, Ibid., 107; S. C. Rowan to L. M. Goldsborough, September 30, 1861, Ibid., 270; J. W. Cooke to W. F. Lynch, April 16, 1862, Ibid., 597-598; Wm M. Hunter to S. S. Lee, January 9, 1865, O.R.N., Ser. 1, Vol. 16, 498; Frederick Douglass, January 1842 lecture, quoted in Benjamin Quarles, Black Abolitionists (New York: Oxford University Press, 1969), 63.

${ }^{84}$ Michael Bennett, “"Frictions,” 145, note 36 (first quote).
} 
sure, African Americans continued to eat and sleep next to white shipmen during the late nineteenth century, preserving the Navy's status as the sole integrated branch.

Nevertheless, as the twentieth century approached, signs indicated that African Americans' status was changing. Trends in pre-service occupations between the 1870s and the 1890s demonstrated this: as mariners' proportion fell from thirteen to six percent, that of service workers like cooks and waiters rose from a third to half of all black sailors. Paralleling the rise of Jim Crow in the country generally, culminating in Plessy v. Furguson, the Navy spent the turn of the century segregating its ships on a large scale for the first time. Thus, the Navy was shifting from being less a segment of a prosperous black maritime community to more an avenue of escape from civilian black poverty. Following the example of public institutions and workplaces becoming segregated throughout American society, naval vessels in the 1890s and 1900s started shifting from having racially-mixed areas to maintaining separate spaces for the two races. A key factor was the Navy's construction of steel battleships to aid overseas commercial and imperial efforts. When manning these new vessels, the service trained civilians lacking in seafaring backgrounds rather than rely on the culturally diverse pool of merchant sailors. The new vessels enforced a specialized, de jure ratings system. Though African-American sailors had struggled to advance from landsmen to seamen throughout the nineteenth century and remained mostly confined to manual labor and service positions, it was through de facto practices on the ground. This new Navy established a messman branch, into which black sailors were trapped without hope of transfer or promotion. As one naval scholar puts it, this organizational change "marked a perceptible shift toward the drawing of a line of demarcation between white and black sailors." To be sure, blacks were still present in every major naval engagement of, and won medals for 
heroically serving in, the Spanish American War. ${ }^{85}$ Recognition for this exceptional service, however, failed to stem the tide of segregation, the social context for the last major waves of black military mutinies.

The Old Navy placed black men far ahead most of the rest of their people on the long emancipation process; the New Navy created the conditions for black sailors' position to regress to that of the average African American in the Jim Crow United States. Due to the relative racial egalitarianism borne out of shared suffering and integration, mutinies in the service of the long emancipation rarely happened. On the more oppressive slave ship and merchant boat, African Americans showed their country and the international community that they were willing to spill blood and sacrifice themselves to ensure that by the time they returned to land, they were more in control of their material well-being and bodies than when they first set sail. Naval mutinies continued to be rare into the first four decades of the twentieth century, but more as a result of a near- or total ban of African Americans during much of that time period. Once a large influx of black men joined the Navy amidst World War II's mass mobilization and social winds that advanced the modern civil rights movement, black naval mutinies became a frequent occurrence from the 1940s to 1970s, just as much as they were in the Army throughout and on nineteenthcentury merchant and slave vessels.

\footnotetext{
${ }^{85}$ Michael S. Davis, “'Many of Them are Among my Best Men,” 45-52; Charles Hughes Williams III, “'We Have...Kept the Negroes' Goodwill and Sent Them Away': Black Sailors, White Dominion in the New Navy, 18931942," MA Thesis, Texas A\&M University, 2008, 3; Denis D. Nelson, The Integration of the Negro into the U.S. Navy, 6.
} 


\section{Chapter 2 \\ "Strong, united, persistent protest": Mutinies of the United States Colored Troops during the Wartime Collapse of Slavery}

When the paymaster arrived in July 1864 and again in August, most of the men in the Pennsylvania-based Thirty-second United States Colored Infantry (USCI), then serving in South Carolina, refused their money. At seven dollars, the monthly compensation African-American soldiers like them received amounted to six dollars less than what white Union troops earned. Their white officers encouraged them to instead accept the inferior pay, assuring them that eventually they would receive what the Army owed them. Yet, when these superiors realized that their men refused to budge, the former started physically abusing the latter as punishment for rebelliousness. As a private writing an account of the incident termed it, the protesters found themselves treated "like dogs": bucking and gagging, placement on a knapsack drill, and ordered to stand in the hot sun for four hours. The soldier's letter decried these injustices as "bad," "ridiculous," and "a shame." Another soldier told the Christian Recorder that "there were but few" for the Army to pay because of his and his comrades' peer pressure to reject the insulting paycheck. These troops stand out because they avoided formal court-martial proceedings. Though no one involved used the word "mutiny" to describe the Thirty-second USCI's resistance, the rank-and-file's defiance of their superiors' authority and the seriousness with which the officers approached the paycheck refusals placed the incident among a large outbreak of black mutinies that hit the Union Army during the American Civil War. ${ }^{86}$

\footnotetext{
86 "B. W., Private, Thirty-second USCI, Morris Island, South Carolina, July 8, 1864," Christian Recorder, July 30, August 9, 1864, quoted in Edwin S. Redkey, A Grand Army of Black Men: Letters from African-American Soldiers in the Union Army, 1861-1865 (Cambridge: Cambridge University Press, 1992), 258-261; Keith P. Wilson, Campfires Of Freedom: The Camp Life of Black Soldiers during the Civil War (Kent and London: Kent State University Press, 2002), 51.
} 
The injustices the Thirty-second endured — unequal pay and physical abuse—-brought this mutinous wave to numerous U.S. Colored Troops (USCT) camps. The campaigns that many African-American soldiers waged against discrimination motivated some to take extreme individual and collective actions including mutiny, which in turn caused Army commanders, journalists, and American society at large to debate how the Union Army should properly use black troops during its operations, as well as how these troops should appropriately respond to such treatment. As this chapter reveals, the Civil War's black soldier mutinies, the circumstances that spawned them, and American society's reactions to them all shed light on a particular watershed moment in U.S. race relations and citizenship rights.

The century of African-American mutinies against the discriminatory policies and practices of a segregated U.S. military began with the formal entry of black men into the U.S. Army during the Civil War. While it was rare for black sailors to revolt until the twentieth century, African Americans in the country's land-based forces participated in numerous mutinous episodes from the moment they enlisted. As southern slavery was in the midst of collapse and as the country at large began to grapple with what a Union without bondage would look like, the reactions to discrimination by black infantrymen, cavalrymen, and artillerymen are key to understanding the long emancipation. These actions demonstrated how determined African Americans were to take advantage of a sectional crisis to combat racial power relations. In the long term, wartime USCT mutinies helped pave the way for how blacks advanced the freedom struggle in the decades between the end of slavery and the course of the modern civil rights movement. While the specific motivations for mutinying evolved from the Civil War to twentieth-century conflicts, the former introduced black troops to the inequality and abuse that systems of racial segregation breed. Their sentiments toward, and responses to, real and 
perceived racism while in uniform set the stage for a century of African-American history. It was during the Civil War that would-be and actual black mutineers experienced their initial encounters with a number of factors shaping their experience over the decades: the utility of mutinying vs. less overt alternatives; the importance of white allies; barriers to legal redresses of grievances; and gaps between expectations for, and the reality of, one's military service.

By beginning the fight against wage labor in the U.S. Army, the Civil War's black soldier mutinies lend further credence to the notion that emancipation constituted a long-term process rather than a single event. This process temporally moved far beyond the destruction of chattel slavery between the outbreak of civil war in early 1861 and the ratification of the Thirteenth Amendment in late 1865. The Civil War's wave of USCT mutinies against financial and physical oppression in the ranks demonstrates that the black freedom struggle entailed more than attacks on bondage; more work needed to be done to give substance to black freedom after slavery.

The USCT mutiny phenomenon engages the debate over who among the Civil War generation could claim responsibility for breaking bondspeople's chains and how exactly this came about. Generally, military historians credit the Union Army's operations; political historians give the honor to coercive and legislative actions from the federal government, especially the Emancipation Proclamation; and social historians argue that the enslaved people freed themselves when they fled to Union lines and performed essential labor for the Federal war effort, thereby pushing U.S. forces to become an army of liberation. A number of factorsUSCT mutineers considered it their responsibility to take the initiative to prevent reenslavement; the overall campaign against unequal pay eventually succeeded; and white commanders occasionally seconded mutineers' grievances—strengthen the social history argument. However, the perpetrators of defeated mutinies who requested the aid of white allies 
while using deferential language, along with sympathetic officers who never prompted their men to revolt, give credence to military and political interpretations that emphasize the essential decisions of white officials. ${ }^{87}$ Merging the "long emancipation" and "who freed the slaves?" subfields, this chapter examines responsibility for giving substance to the liberty of freedpeople and their descendants, which mutineers and their white allies claimed for themselves.

In showing how some African-American men highlighted glaring misgivings with the progress of race relations despite the Union helping to liberate their people, this chapter joins recent works challenging the triumphalist narrative of emancipation historiography. However, it also takes the more nuanced approach of some recent works that cautiously approach the "dark turn" in Civil War scholarship. Amidst the physical suffering and emotional turmoil of the emancipation process studied in Jim Downs' Sick from Freedom, there were also cases of whites recognizing blacks' worthiness for freedom and blacks learning that their social position would not regress to re-enslavement, as some feared. To be sure, USCT mutinies mostly highlight the dark side of the equation. Yet, the complex, variable nature of the black Civil War experience, captured in Chandra Manning's Troubled Refuge, Amy Amy Murrell Taylor's Embattled Freedom, and essays in Rethinking Emancipation, is also apparent when studying the decision of the Sable Arm to revolt or to not do so. On one hand, mutinies prove that Joseph Glatthaar exaggerates the degree to which the white officer-black soldier relationship was cordial; on the other, the absence of mutinous episodes in the careers of some USCT units at certain times and in particular places prevents us from over-generalizing in the other direction. That a number of

\footnotetext{
${ }^{87}$ Gary Gallagher, The Union War (Cambridge: Harvard University Press, 2011); James McPherson, Drawn with the Sword: Reflections on the American Civil War (New York: Oxford University Press, 1996); 1 Robert F. Engs, "The Great American Slave Rebellion," paper delivered to the Civil War Institute at Gettysburg College, 27 June 1991; David Williams, I Freed Myself: African American Self-Emancipation in the Civil War Era (New York: Cambridge University Press, 2014). For answers to these questions across the spectrum, see Rethinking American Emancipation, eds., William A. Link and James J. Broomall; James M. McPherson, "Who Freed the Slaves?" Proceedings of the American Philosophical Society Vol. 139, No. 1 (March 1995), 1-10.
} 
black men in blue made the risky choice to lead or join a rebellion shows that this generation perceived their newly-won rights to be in danger but also still within reach if they fought harder for them. Historians should strive to capture both triumph and tragedy in their works. ${ }^{88}$

While black Union soldiers correctly framed undesirable circumstances and policies as discrimination, their white counterparts could cite a relatively similar ordeal of freedoms under siege. Over the course of the war, members of one Maine and four New York units stacked up their arms against the government's failure to pay them, leaving their families destitute, and/or its decision to lengthen their terms of service. At least four commands- the Fifteenth Pennsylvania Cavalry, the Forty-fourth New York Infantry, the Second Rhode Island Cavalry, and the Loudoun Virginia Independent Rangers — resisted unit consolidation orders that infringed on local or state allegiances and the right to choose which types of duties to perform. White mutineers also defended the right to elect commanders. As Thaddeus Romansky reveals in his study of Union Army mutinies, white mutineers drew on Anglo-American traditions of selfgovernment: the "scrutinizing (of) governments" when the state violated its obligations to citizens and the right to form associations possessing autonomy from centralized authority. ${ }^{89}$

Also like USCTs, white Union mutineers risked severe punishment when fighting for their liberties. As scholars of Union Army discipline note, officers did not hesitate to swiftly use force against boisterous white enlistees, the latter of whom generally resisted the former's harsh

\footnotetext{
${ }^{88}$ Jim Downs, Sick from Freedom: African-American Illness and Suffering during the Civil War and Reconstruction (New York: Oxford University Press, 2012); Chandra Manning, Troubled Refuge: Struggling for Freedom in the Civil War (New York: Vintage Books, 2016); Amy Murrell Taylor, Embattled Freedom: Journeys through the Civil War's Slave Refugee Camps (Chapel Hill: University of North Carolina Press, 2018); Joseph Glaathaar, Forged in Battle; Rethinking American Emancipation, William A. Link and James J. Broomall, eds., 4, 9.

${ }^{89}$ For every mentioned white mutiny except that of the Loudoun Rangers, see Thaddeus M. Romansky, "Disunion in the Ranks: Soldiers, Citizenship, and Mutiny in the Union Army," PhD dissertation, Texas A\&M University, 2015, (quote on 100). For coverage of the Rangers' mutiny, see Scott Thompson, "The Irregular War in Loudoun County, Virginia," in The Guerrilla Hunters: Exploring the Civil War's Irregular Conflicts, Barton A. Myers \& Brian D. McKnight, eds., 123-146 (Baton Rouge: Louisiana State University Press, 2017).
} 
disciplinary measures like the tying up of limbs. Though black mutineers framed physical abuse as an outgrowth of plantation justice, white Union soldiers faced cruel treatment rooted in northern socioeconomic tensions. Affluent officers subscribed to a refined model of masculinity; the working-class rank-and-file were committed to martial masculinity. Comparable to convicted black mutineers, whites received a range of punishments for similar crimes: most received loss of pay, dishonorable discharges, and hard labor; the Army only gave a small number the maximum penalty, execution. Most imprisoned mutineers, white and black, successfully appealed for reduced sentences, or someone did so on their behalf, especially once the Union Army demobilized after the war. The military justice system at times prosecuted most alleged perpetrators of an incident; at others, it singled out the ringleader(s). As with white and black sailors, Army personnel from both racial groups could cite threats to their liberty understood in the context of American political culture, but for African Americans, the threat always operated in the context of their unique past based on a struggle against racial oppression. ${ }^{90}$

A sample of twenty-one African-American mutinies and seventeen white mutinies offers an equivocal answer to whether the Union Army, a segregated institution with documented racially discriminatory practices, treated black offenders worse than whites during the Civil War. Five of the white mutinies (29\%) resulted in hard labor sentences, while ten black revolts (nearly half) did so. Discounting commutations and rulings lacking a specified length of imprisonment, the average white hard labor sentence equated 8.3 months and black sentences averaged 13.1 months. Courts-martial ruled that twenty-four African Americans would toil for the remainder of

\footnotetext{
${ }^{90}$ Lorien Foote, The Gentlemen and the Roughs, 156; Steven J. Ramold, Baring the Iron Hand: Discipline in the Union Army (DeKalb, IL: Northern Illinois University Press, 2009), 205. On white soldiers cutting down comrades tied up for punishment, see Ramold, 363; Proceedings of a General Court-Martial, Trial of Private William Daniels, OO-188, RG 153, NARA. For more thorough analysis of racial equality in the Union Army justice system, see the immediate postbellum chapter.
} 
their terms, but officials told 201 members of the white Twentieth New York, who mutinied together in a single episode, that they would do so for the duration of the war. It was rare for either black or white mutineers to suffer capital punishment. Officials gave the death penalty to three mutinous USCTs. While no court-martial decided to execute a white mutineer, two white ringleaders died at the hands of a summary firing squad. Since the Twentieth New York mutineers also received dishonorable discharges, more white (202 of 212, or 95\%) than black defendants (twenty-three of fifty-five, or 42\%) suffered the disgrace of expulsion from the Army because they chose to rebel. If we remove the Twentieth New York, only one white mutineer of eleven $(9.1 \%)$ suffered a dishonorable discharge. The other possible punishment for those courtmartialed - the partial or total loss of pay-occurred in thirteen of twenty-one (62\%) black mutinies and nine of seventeen (53\%) white rebellions. When either a white or black soldier stood trial, the Army generally found them guilty, with each racial group in the sample containing two full acquittals and one acquittal for mutiny plus conviction for a lesser crime.

Moreover, a pattern in both groups indicates that whenever a mutiny consumed most or the entirety of a unit, and it avoided engaging in violence or other physical force, officers were less willing to prosecute non-ringleaders. Nine white mutinies saw anywhere from a whole company to regiment revolt, with only the Twentieth New York subject to mass court-martial proceedings, three units' officers being informally dismissed, another seeing thirty-five mutineers put in custody for several months before being released, and one command whose two ringleaders informally faced a firing squad. Meanwhile, of the five USCT mutinies that fit this category, only a single sergeant of one episode was prosecuted; a second event saw authorities arrest and then release the perpetrators; and a third resulted in the mutineers being bucked, 
gagged, and ordered to stand in the hot sun but ultimately released. The Union Army spared one third of mass white mutinies and two-fifths of the black ones any sort of punishment. ${ }^{91}$

A number of lessons can be derived from this sample. Overall, USCTs tended to receive harsher hard labor sentences and endure a greater likelihood of losing wages; whites were statistically far more or less likely to be dishonorably discharged, depending on whether we include the Twentieth New York or not; only a small handful in each group were executed or acquitted by courts-martial; and strength in numbers generally limited punishment to black and white ringleaders. In certain areas, the Union Army engaged in a degree of relative racial equality when prosecuting the most serious military crime. One can come to two possible conclusions or a combination of both regarding the data that demonstrated unfavorable treatment from white court officials towards black enlistees accused of mutiny: either white northerners were more committed to punishing guilty blacks, or they viewed white motivators of mutinyopposition to unit restructuring without their input - in more sympathetic terms. Further, to the extent that black Civil War troops might have desired the rights and privileges that came with whites' preferred unit missions and organization method, more immediate concerns, like forcing the government to fulfill its stated promise to pay them equally, took precedence.

While USCT revolts during the Civil War shared elements with those of later periods, the former occurred in their own contexts. With their emphasis on demanding better compensation

\footnotetext{
${ }^{91}$ Data based on spreadsheet in author's files. The white units involved were the Anderson Cavalry (Fifteenth Pennsylvania), First Louisiana Cavalry (Union), Second New York Infantry, Third Arkansas Cavalry, Fourth Massachusetts Cavalry, Fourth Maine Infantry, Seventh Vermont Infantry, Ninth New York Infantry, Eleventh Missouri Cavalry, Twentieth New York Infantry, Twenty-first New York Battery, Thirty-ninth New York Infantry, Forty-fourth New York Infantry, Seventy-ninth New York Infantry, Ninety-third New York Infantry, Second Rhode Island Infantry, the Marine Regiment, and the Loudoun Rangers. The African-American units cited were the Third South Carolina Infantry, Fifty-fourth Massachusetts Infantry, Fifty-fifth Massachusetts Infantry, Thirteenth USCI, Forty-ninth USCI, Fourteenth Rhode Island USCHA, Twenty-fifth USCI, Thirty-second USCI, Thirty-sixth USCI, Thirty-third USCI, Fifty-seventh USCI, Seventy-sixth USCI, Eighty-first USCI, Eighty-fourth USCI, and 113th USCI. This sample excludes the mutinies that hit the Union Army in the immediate postbellum months, the subject of the next chapter.
} 
and working conditions and their tendency to apply the tactics of worker strikes, wartime mutinies were distinct in the degree to which they linked with nineteenth-century black labor history. Also, in contrast to later black mutinies, the wartime context meant that mutineers knew that slavery's death was not a forgone conclusion. As James McPherson has pointed out, since northern public opinion on emancipation and the military's ability to protect contrabands relapsed at key moments, "the tide of freedom could have been swept back" throughout the war. ${ }^{92}$ Blacks nevertheless had high hopes for their future once the armed conflict with Confederates morphed into a social revolution. While these hopes failed to completely materialize in the coming years, subsequent wars over the next century resurrected and then dashed dreams of racial equality achieved through military service. Repeatedly, it was when these dreams seemed most at risk that some African-American soldiers overtly challenged the authority of superiors.

When examining the long emancipation, black soldier mutinies against discrimination during the Civil War form part of an extended narrative of black labor strikes and slave resistance across the nineteenth century. Just as some black Union soldiers refused to perform their duty or otherwise physically objected to insufficient compensation and dangerous working conditions for their labor-intensive service, African-American civilians conducted work stoppages to promote their material well-being during the antebellum years. As the Market Revolution created industrial workplaces, an early labor movement emerged among male and female, white and black workers who resented dependence on wage labor in a boom-and-bust economy. Meanwhile, bondspeople never ceased the forms of resistance against their horrific

\footnotetext{
92 James M. McPherson, "Who Freed the Slaves?" Proceedings of the American Philosophical Society Vol. 139, No. 1 (March 1995), 1-10, quote on page 9.
} 
circumstances conducted since the peculiar institution's founding. When USCTs mutinied, they were following in the footsteps of predecessors who also struck for more control over their labor.

Among the many ways in which enslaved black workers resisted their oppression was by engaging in truancy until authorities met certain demands. In 1837, an overseer on a Georgia plantation reported that six bondsmen fled when he "gave some of them a few lashes" as punishment for inadequate work. The overseer expected them to return once they could speak with their owner. An 1856 slave narrative by John Holmes revealed that he hid in a swamp in response to an overseer's threat to whip him. He refused to reappear until, "they told all the neighbors...they wouldn't" do so. To forcibly improve conditions, slaves withheld their labor. ${ }^{93}$

Also in response to the brutal nature of bondage, enslaved people inflicted damage on plantation property or personnel. Scholars of slave resistance have identified subtle and overt types of resistance: verbally disapproving of provisions, destruction of tools, theft, arson, injuring or murdering a master or overseer, and insurrection. Others tried escaping the plantation permanently, seeking the free North, Canada, or maroon communities. Through the forceful use of weapons and limbs, violent black mutineers' own blows against white oppression built on this foundation of slave resistance. ${ }^{94}$

Among the earliest instances of free African Americans conducting the long emancipation via a work stoppage was the Washington Navy Yard strike by black and white

\footnotetext{
${ }^{93}$ Letter of I.E.H. Harvey, April 16, 1837, quoted in Ulrich B. Phillips, American Negro Slavery (New York: D. Appleton and Co., 1918), 303; Thomas Drew, The Refugee or the Narratives of Fugitive Slaves in Canada. Related by Themselves, with an Account of the History and Condition of the Colored Population of Upper Canada (Boston: John P. Jewett and Co., 1856), 164.

${ }^{94}$ Joseph Angell to Robert Wickliffe, May 5, 1858, Wickliffe-Preston Papers, Special Collections, University of Kentucky Library, Lexington, KY; James A. Ramage and Andrea S. Watkins, Kentucky Rising: Democracy, Slavery, and Culture from the Early Republic and the Civil War (Lexington, Kentucky: University Press of Kentucky, 2011), 248-251; John W. Blassingame, The Slave Community: Plantation Life in the Antebellum South (New York and Oxford: Oxford University Press, 1972), 192-248; "Ellen Wallace Diary, 1849, 1864-1865," Ellen Wallace and Annie Starling Diaries, MSS 52, Kentucky Historical Society, Frankfurt, KY.
} 
caulkers and carpenters between late July and mid-August 1835 . Various safety hazards and the long hours of those who toiled at the Washington Navy Yard eventually motivated three-quarters of the workforce to strike when a new commandant enacted a series of strict mealtime rules on the grounds that employees stole items from the workplace. One black Washington Ship Yard worker and former slave, Michael Shiner, described about how coworkers responded to the policy: feeling insulted, "evry one of them struck and said they wouldnt work anny moore." To end the strike, Hull agreed to remove the accusations of thievery from the rules. ${ }^{95}$

Even antebellum-era free black southerners who enjoyed a more advanced position along the emancipation process found resistance necessary. In July 1838, a mulatto barber and bathhouse keeper named Anderson defended his Wheeling shop from a white customer who refused to pay. An altercation broke out during which Anderson "raised his hat" and "struck the rascal." For acting forcefully towards a white man, Anderson incurred the wrath of Virginia law enforcement and a cycle of mob violence that led to the town banishing him to secure the peace. While more economically autonomous than a wage laborer, this mixed-race shop owner still needed to aggressively prove his worthiness for freedom from white attacks on his finances and

\footnotetext{
${ }^{95}$ Lori Latrice Martin, et. al., Lessons from the Black Working Class: Foreshadowing America's Economic Health (Santa Barbara, CA: Praeger, 2015), 17; Naval History and Heritage Command, "The Diary of Michael Shiner Relating to the History of the Washington Navy Yard 1813-1869," Transcribed with Introduction and Notes by John G. Sharp (2007 and 2015), https://www.history.navy.mil/research/library/online-reading-room/title-listalphabetically/d/diary-of-michael-shiner.html; Naval History and Heritage Command, "General Orders for the Regulation of the Navy Yard, Washington, DC (circa 1833 - 1850 Washington Navy Yard, orders no. 13 and 14)," https://www.history.navy.mil/research/library/online-reading-room/title-list-alphabetically/d/diary-of-michaelshiner.html, note 50; Norman Hill, "Forging a partnership between blacks and unions," Monthly Labor Review Vol. 110, No. 8 (August 1987), p. 38; Linda M. Maloney, The Captain from Connecticut: The Life and Naval Times of Isaac Hull (Boston: Northeastern University Press, 1986), 422, 438-439; John G. Sharp, History of the Washington Navy Yard Civilian Workforce, 1799-1962 (Naval District Washington: Washington Navy Yard, 2005), https://www.history.navy.mil/content/dam/nhhc/browse-by-topic/heritage/washington-navyyard/pdfs/WNY_History.pdf.
} 
person. He thereby foreshadowed the black prosperity that incited Jim Crow's rise later in the century. ${ }^{96}$

The ways in which contrabands occupied a twilight zone between slavery and freedom further helps set the stage on which USCT mutinies erupted. As southern slavery collapsed, blacks tried to purge the country of remnants of slavery, which deprived them of economic independence and control over their own labor. Such actions were especially important during the Civil War because Americans lacked the benefit of knowing that bondage would cease existing as an institution by the end of 1865 . As Chandra Manning emphasizes in her work on contraband camps, the four hundred thousand refugees who arrived in Union lines entered a "liminal stage" between bondsperson and citizen. Similarly, Amy Murrell Taylor's examination of these camps notes how African Americans' journey from slavery to freedom moved in "slow motion" and often "was...continually constructed—built and rebuilt again" throughout the war. Studying enslaved and freed peoples' literacy, Christopher Hager notes how freedom during and after the war often took on the following characteristics: "bounded, contingent, and...illusory." For blacks, overt action became desirable because they lived under the persistent threat of either returning to slavery or entering a new system with subtler elements of the old order. ${ }^{97}$

Almost immediately after the war broke out, and increasingly as the Union adopted an emancipationist effort, runaway bondspeople headed to U.S. lines, where they struggled to attain independent living arrangements. In creating a free labor system in the South, Federal officers and northern civilians obstructed their path to land ownership, which freedpeople saw as the only

\footnotetext{
${ }^{96}$ Edward Canning to Josiah Canning, July 22, 1838, MS80-95, Canning Family Papers, West Virginia State Archives, Charleston, WV.

${ }^{97}$ Stephanie Camp, Closer to Freedom (Chapel Hill: University of North Carolina Press, 2004); Chandra Manning, Troubled Refuge, 12; Amy Murrell Taylor, Embattled Freedom, 8, 239; Christopher Hager, Word by Word: Emancipation and the Act of Writing (Cambridge: Harvard University Press, 2013), 4. As Camp reveals, bondspeople used long-established truancy networks built under slavery to permanently flee to Union lines once war broke out.
} 
substantive course for material security and autonomy. As an ex-slave contended, the key for their future prosperity was when those "who have watered the soil with their tears and blood" are "allowed to own it when they have earned it by their own labor." 98

In Union camps, contrabands became impoverished and dispossessed military laborers, constructing fortifications, operating wharfs, or growing crops on Federal-run "government farms." Initially, the high command only distributed rations to contrabands. When officials started paying wages, this compensation fell short of what able-bodied men needed to support their dependents. Throughout the Union-occupied South, contrabands suffered from poor shelter, disease, death, robbery, and abuse from white soldiers, which encouraged some to flee the camps. The persistence of low, nonexistent, or delayed payments created black disillusionment with free labor and confirmed their preference for land ownership over wage earning. Meanwhile, many Union commanders interpreted freedpeople's desires for autonomy, subsistence, and leisure as signs of blacks' inherent laziness when free from the driver and the lash. Among the most crushing defeats to landed freedom was the decision of direct-tax commissioners in February 1864 to abort a plan to sell government-seized land to ex-slaves in the South Carolina Sea Islands, even after some had purchased plots. ${ }^{99}$

\footnotetext{
${ }^{98}$ Quote on Ira Berlin, et. al., Freedom: A Documentary History of Emancipation, 1861-1867, Series I, Volume II, The Wartime Genesis of Free Labor: The Upper South (Cambridge: Cambridge University Press, 1993), 100. For recent scholarship studying the conditions of contraband camps in depth, see Chandra Manning, Troubled Refuge; David Silkenat, Driven from Home: North Carolina's Civil War Refugee Crisis (Athens: University of Georgia Press, 2016).

${ }^{99}$ Testimony of B. K. Lee, Jr., to the American Freedmen's Inquiry Commission, June 1863, filed with O-328 1863, Letters Received, Series 12, RG 94, quoted in Ira Berlin, et. al., Ira Berlin, et. al., Freedom: A Documentary History of Emancipation, 1861-1867: Series 1, Volume 3: The Wartime Genesis of Free Labor: The Lower South (Cambridge: Cambridge University Press, 1990), 113-114; Testimony of Captain C. B. Wilder to the American Freedmen's Inquiry Commission, May 9, 1863, O-328 1863, Letters Received, Series 12, RG 94 (K-68), quoted in Ira Berlin, et. al., The Wartime Genesis of Free Labor: The Upper South, 142-146; Major General John A. Dix to E. M. Stanton, November 22, 1862, Volume -/3 VaNc, 423-424, Letters Sent, Series 5046, Department of Virginia and Seventh Army Corps, RG 393 Pt 1 (C-3208), quoted in Ibid., 136-137; D. Heaton to S. P. Chase, May 20, 1864, enclosed in D. Heaton to The Secretary of the Treasury, May 31, 1864, H-64 1864, Letters Received by the Division, Series 315, Division of Captured Property, Claims, and Land, RG 56 (X-74), quoted in Ibid., 195-199; Affidavit of Suthey Parker, September 2, 1865, "Negroes: Employment," Consolidated Correspondence File, Series
} 
These circumstances explain why blacks viewed their emancipation vision as so incomplete that it necessitated resistance. The emancipation process was far from linear; the formerly or currently enslaved occupied different stages in different places at different times. Their progress advanced forward, regressed, or stagnated, depending on the white personnel with whom they worked and lived. African Americans thereby concluded that resisting racial injustice in the Union was as important as fighting slavery in the Confederacy. ${ }^{100}$

Infringements of freedpeople's notions of labor rights and economic independence motivated some who were becoming accustomed to wartime opportunities for material wellbeing to actively obstruct this violation through their own examples of labor unrest. When officers in January 1862 cut rations to laborers' hungry families, several stopped working. Officials jailed and whipped the strikers. Abolitionists condemned the Union Army's system of abusive labor, deeming it "government slavery." Less sympathetic commanders repeatedly expressed concerns over contraband families over-burdening Federal resources. The severe punishment distributed among the strike's perpetrators foreshadowed the risks black soldiers later took to their physical well-being when they rebelled against white officers. Though a minority, strikers show that African Americans navigating the gray area between slavery and

225, Central Records, RG 92 (Y-719), quoted in Ibid., 110-111; Brig. General W. T. Sherman to General L. Thomas, December 15, 1861, filed with S-1491 1861, Letters received, series 12, RG 94, Samuel H. Terry to Hon. S. P. Chase, December 18, 1861, vol. 19, \#22, Port Royal Correspondence, $5^{\text {th }}$ Agency, RG 366, quoted in Ira Berlin, et. al., The Wartime Genesis of Free Labor: The Lower South, 118-121; Brig. General R. Saxton to Hon. Edwin M. Stanton, December 30, 1864, S-2775 1864, Letters Received, ser. 122, RG 94, quoted in ibid., 322-231; William Henry Brisbane to Hon. Joseph J. Lewis, December 12, 1863, General Correspondence, ser. 99, SC, Records of or Relating to Direct Tax Commissions in the Southern States, RG 58, quoted in Ibid., 276-277; Brig. General R. Saxton to Hon. Edwin M. Stanton, December 30, 1864, S-2775 1864, Letters Received, ser. 12, RG 94, quoted in Ibid., 326-328.

${ }^{100}$ Chandra Manning, Troubled Refuge, 8. 
freedom had grievances and disappointments. Those who resisted such setbacks had lost patience and felt that legal recourses either had been exhausted or did not exist. ${ }^{101}$

While some chose overt resistance, wartime petitions represented a preferred means for aggrieved, but still hopeful, African Americans to improve their lives and escape oppression during the Civil War era. As scholarship on the relationship between writing and emancipation reveals, literacy "symbolized the end of" blacks' "enslavement, but it also was a dizzyingly new part of their venture into an uncertain era." Merely composing, signing, and/or distributing a petition itself constituted revolutionary acts because slavery sternly prohibited reading and writing. For current or former slaves to become literate, they performed a difficult feat requiring initiative, hard work, limited instruction, and the risk of physical punishment. Moreover, developing reading and writing skills enabled blacks to understand what liberty in the U.S. meant. As blacks used the Civil War to escape bondage, they could more freely foster these skills and pursue unprecedented access to formal schooling. That freedpeople produced writings expressing grievances and addressed to Union Army officials, who in turn read them, signified that the emancipation process had advanced forward. However, there was no guarantee that the relevant personnel would act in these authors' favor, demonstrating further the tenuous nature of black freedom. Frustration with the limited ability of written or spoken words to end discrimination in the Army created the conditions for overt resistance. ${ }^{102}$

\footnotetext{
${ }^{101}$ Ira Berlin, et. al., The Wartime Genesis of Free Labor: The Upper South, 88. June 1862 witnessed Ship Island nearly experience its own contraband labor strike. With its "men and artisans...in almost a state of mutiny for want of pay," Benjamin Butler found a way to pay these essential laborers and prevent their families from starving. See OR, Series 1, Volume 15, 470. See Maj. Of Engrs. C. Seaforth to Brigadier General Joseph G. Totten, December 11, 1863, Engineer 79, 1863, Letters Received from the President, Executive Departments, and War Department Bureaus, RG 107 (L-321), quoted in Ira Berlin, et. al., The Wartime Genesis of Free Labor: The Upper South, 174177. Instances also exist of Union Army black laborers being strikebreakers instead of strikers. In December 1863, a Fort Monroe engineer complained about the difficulty of securing labor. He revealed that a year ago, imported northern laborers of Irish and German origin struck, leading to their discharge and replacement with lesser-paid black workers.

${ }^{102}$ Christopher Hager, Word by Word, 3-5, 9.
} 
The Union Army's practice of impressing black laborers sparked an uproar that dominated petitions. Impressment, like the peculiar institution, violated the right of African Americans to freely live where they wanted and forcibly separated family members. Northern minister Lewis C. Lockwood described impressment as a continuation of slavery. In a November 1863 petition to recognized white ally Benjamin Butler, seventeen North Carolina freedmen denounced impressment without compensation, noting that it prevented them from paying their rent and providing for their families. They begged the general for relief. When the Army failed to follow orders for better treatment, freedmen felt their last resort was the Lincoln administration. In March 1865, on behalf of freedmen from Roanoke Island, black school teacher Richard Boyle wrote the president and secretary of war asking for clarification of their rights given the coercion within the Army's labor system. They pled for a chance to earn an independent living. ${ }^{103}$ Written protests often fell on unfriendly or deaf ears. A superintendent's July 1865 reply attributed Boyle's petition to blacks feeling entitled to government rations rather than learning self-sufficiency. According to him, they refused to work and received overly generous provisions, of which they were unappreciative. Such responses failed to understand freedpeople's poverty and desire for eventually attaining economic independence. ${ }^{104}$

\footnotetext{
${ }^{103}$ Ira Berlin, et. al., The Wartime Genesis of Free Labor: The Upper South, 98-99, 104; "Statement of Armistead Lewis of Zenia Ohio," September 1863, S-18 1863, Letters Received, Series 360, Colored Troops Division, RG 94 (B-477), quoted in Ira Berlin et. al., Freedom: A Documentary History of Emancipation, 1861-1867, Series II: The Black Military Experience (Cambridge: Cambridge University Press, 1982), 177; Lewis C. Lockwood to Senator Wilson, January 29, 1862, L-130 1862, Letters Received, RG 107 (L-9), and Report of Colonel T. J. Cram et. al, March 1862, V-222 1862, Letters Received, Series 12, RG 94 (K-751), quoted in Ira Berlin, et. al., The Wartime Genesis of Free Labor: The Upper South, 112-120; Robert Henry et al. to Major General B. F. Butler, November 20, 1863, Miscellaneous Letters and Reports Received, Series 5076, Department of VA and NC and Eighteenth Army Corps, RG 393, Part 1 (C-3044), quoted in Ibid., 166-167; Roanoke Island N.C. to Mr. President, March 9, 1865, and Roanoke Island to Secretary of War, March 9, 1865, B-2 1865, Letters Received, Series 15, Washington HQ, RG 105 (A-2966), quoted in Ibid., 231-235.

${ }^{104}$ Captain Horace Grace to Colonel J. S. Fullerton, July 10, 1865, B-2 1865, Letters Received, Series 15, Washington HQ, RG 105 (A-2966), quoted in Ibid., 235-236.
} 
The written protests against impressment shed light on the component of the black vision for emancipation centered on the liberty to live one's life where and how one wants. While in some cases flight from coerced labor served their emancipationist interests, staying put in defiance of impressment could serve the same ends in other circumstances. In both scenarios, the individual in question asserted their right to freedom of movement, a rejection of the authority of whites to constrain or relocate black bodies. Overt acts of resistance became desirable because despite repeated inquiries, freedpeople could never find a clear answer to the question of why the government kept abridging their personal autonomy and well-being.

Finally, the dynamics of black Army enlistment during the war helps provide context for why some enlistees eventually rebelled. From the time they were only prospective soldiers up until the moment they became uniformed mutineers, these men would have observed firsthand numerous examples of how far they had advanced as well as how much more they had to gain in the emancipation process. 180,000 African-American men ultimately desired to push the process forward by serving in the Union Army, enabling them to prove their manhood and worthiness for citizenship while helping topple a slaveholders' republic. Since the outbreak of hostilities, black men tried to enlist in the Federal Army. Though blacks were already serving in the Union Navy, most white northerners initially viewed the conflict as a white man's war with the sole goal of crushing the rebellion with slavery intact. Two years of activism eventually convinced the U.S. government to adopt a policy of black soldier enlistment in a war for liberation. ${ }^{105}$

A prologue to the African-American struggle to secure recruitment in the Union Army and to subsequently mutiny against its racist policies centers on the legacy of black enlistment in the American Revolution and the antebellum efforts by blacks during and after northern

${ }^{105}$ Edwin S. Redkey, A Grand Army of Black Men, 9-10. 
emancipation to engage in armed self-defense. During the American War for Independence,

Patriot state governments granted freedom to slaves who served in the armed forces. Thus, from

the time of the United States' birth, black men linked military service and emancipation. Some of those blacks who lived outside of slavery prior to joining the Union Army owed their status to the military service of their grandfathers. USCTs hoped that contributing to their own generation's war could complete a gradual liberation begun eight decades prior. ${ }^{106}$

Just as USCTs attempted to kill Confederates on the battlefield and mutineers used their status as armed personnel to bring extra change to American race relations, black men in the nineteenth century resisted white supremacy on land by organizing informal armed bands. In the 1850s, amidst the escalating sectional debate over slavery and increasing black militancy, African Americans demanded inclusion in northern militias. During a February 1853 speech to the Massachusetts state legislature, foreshadowing mutineer rhetoric on masculine citizenship, William J. Watkins proclaimed that "We are men, and we wish to be treated, as men in the land of the Pilgrims should be treated." When denied this recognition, independent black militia units formed with private funds across the late-antebellum North to protect black communities from the 1850 Fugitive Slave Act. Whenever whites blocked efforts to promote the right of blacks to defend one's family and community, black resisters chose arms and organization to resist. ${ }^{107}$

\footnotetext{
${ }^{106}$ Alan I. Johnson, "In Search of Freedom: African Americans and Massachusetts' Militia From 1852-1917," Master's Thesis, Brandeis University, 2017, 3-4, https://bir.brandeis.edu/bitstream/handle/10192/33878/JohnsonThesis2017.pdf?sequence=1\&isAllowed=y; Hal Goldman, "Black Citizenship and Military Self-Presentation in Antebellum Massachusetts" Historical Journal of Massachusetts Volume 25, No. 1 (Winter 1997), 158-172. For the general black military experience of the American Revolution, see Benjamin Quarles, The Negro in the American Revolution (Chapel Hill: University of North Carolina Press, 2012); Simon Schama, Rough Crossings: The Slaves, the British, and the American Revolution (New York: HarperCollins, 2006).

${ }^{107}$ Alan I. Johnson, "In Search of Freedom," 6-13; Proceedings of the Colored National Convention, held in Rochester, July 6th, 7th, and 8th, 1853," http://coloredconventions.org/items/show/458; Negro Protest Pamphlets: A Compendium: Volume 1, Dorothy B. Porter, ed. (Arno Press, 1969), 7 (quote); William Cooper Nell, The Colored Patriots of the American Revolution (Boston, 1855), 11, 24-27; James and Lois Horton, Black Bostonians: Family Life and Community Struggle in the Antebellum North (Holmes \& Meier Publishers, Inc, 2000), 121; Hal Goldman, "Black Citizenship and Military Self-Presentation in Antebellum Massachusetts" Historical Journal of
} 
After the enactment of the Emancipation Proclamation at the start of 1863, the U.S. Army agreed to recruit black troops in segregated regiments. Recruitment documents and the national debate over the utility of African-American enlistment all shed light on the white understanding of what motivated black soldiers to fight in the context of slavery's ongoing expiration. This discourse matched how white officers later framed mutinies. The tones and messages of these writings ranged from supportive and progressive to condescending and hostile.

How the Union Army accepted black men into its ranks depended on region. Recruitment in the free states entailed recruiting black men who had already known freedom firsthand but nevertheless still lived in a white supremacist society. Northern governors joined federal officials in organizing units. With the federal government declaring slaves free in the South, black men could volunteer upon entering Union lines. In the border states and Union-occupied Tennessee, places exempted from the Emancipation Proclamation, the Federals encouraged Unionist masters to manumit and enlist their bondsmen in exchange for a financial award. Regardless of how they joined the Army, African-American men responded to perceived injustice in similar manners. ${ }^{108}$ When African Americans early in the Civil War pushed their case for Union Army recruitment, they laid out visions of a biracial democracy that drew on real and imagined examples of military service. Portraying blacks as highly patriotic, they crafted such a policy as

Massachusetts Volume 25, No. 1 (Winter 1997), 158-172; Mary Ellen Snodgrass Civil Disobedience: An Encyclopedic History of Dissidence in the United States (London and New York: Routledge, 2015), 38-40. Formal armed self-defense ironically was more attainable for one group of black southerners, the Gulf Coast creoles. Ira Berlin, Generations of Captivity: A History of African-American Slaves (Harvard University Press, 2003), 141. Also see Roland McConnel, Negro troops of antebellum Louisiana: a history of the Battalion of Free Men of Color (Baton Rouge: Louisiana State University Press, 1968).

${ }^{108}$ Major General George L. Stearns to Hedwin M. Stanton, September 25, 1863, S-18 1863, Letters Received, Series 360, Colored Troops Division, RG 94 (B-477), quoted in Ira Berlin, et. al., The Black Military Experience, 176-177. Created by General Order No. 329, the Slave Claims Commission allowed Unionist masters to manumit their slaves for the purpose of enlistment and to claim monetary compensation. If applicants proved their loyalty to the Union and ownership over the enlistee, they received a $\$ 100$ bounty immediately and a promised payment of $\$ 300$ after the war. See Records of the Slave Claims Commission, Preliminary Inventory of the Records of the Adjutant General's Office, Entries 348 and 350, RG 94, NARA; Compiled Service Records of United States Colored Troops, RG 94, NARA, www.fold3.com. 
necessary to save the Union and to put down the rebellion. While it is unclear if these men sincerely subscribed to Unionist ideology, the key to winning over white allies to the cause was appealing to the latter's allegiances. A small number of free blacks joined white regiments early in the war as ambiguous "independent men." Writing to the black paper Pine and Palm during his year of service, one such soldier, William Johnson, blamed the loss at First Bull Run on the supposed Confederate use of enslaved soldiers. He continued the letter with a call for the Union to start recruiting blacks for an antislavery crusade. In November 1861, bridging antebellum militia service and Civil War enlistment, a "defensive association” of African Americans from Connecticut formed in preparation for potential black military recruitment. ${ }^{109}$

Just as they did over poor compensation, black civilian workers in the Union Army engaged in the equivalent of labor strikes to jumpstart the process of black enlistment. In February 1863, a lieutenant reported that one hundred contrabands at a North Carolina camp "had refused to work" due to their "impression that they were soldiers" in a new regiment. An unidentified white soldier who agreed with their new status led them in performing drills. Authorities arrested the individuals and informed them that the Army had not yet authorized their unit's formation. Despite the willingness to enlist, they were still bound to their labor duties.

\footnotetext{
109 “William H. Johnson, Second Connecticut Infantry, Washington, D.C., July 24, 1861,” Pine and Palm, August 3, 1861, quoted in Edwin S. Redkey, A Grand Army of Black Men, 10-12; "William H. Johnson, Eighth Connecticut Infantry, Anapolis, Maryland, November 11, 1861," Pine and Palm, November 23, 1861, quoted in Edwin S. Redkey, A Grand Army of Black Men, 12-13. As scholars have found, and what neo-Confederates conveniently ignore, is that such observations only come from Union sources written early in the war whose purpose was to push for an emancipationist war effort. If any black men did fight for the Rebel Army during any battle, they were body servants whose masters compelled them to fire a musket at the Yankees or who performed noncombat duties that Federals blinded by the fog of war misinterpreted. No mention of a single black Confederate unit appears in C.S. records, and the Richmond government vehemently rejected proposals to arm slaves until late in the war. For additional sources making the same claim, see William A. Jones to Hon. S. Cameron, November 27, 1861, J-52 1861, Letters Received Irregular, RG 107 (L-91), quoted in Ira Berlin, et. al., The Black Military Experience, 80-81; Governor Richard Yates to President Lincoln, July 11, 1862, Telegrams Collected by the Office of the Secretary of War, RG 107 (L-205), quoted in Ibid., 84-85. For scholarly examinations on the topic, see Glenn D. Brasher, The Peninsula Campaign and the Necessity of Emancipation: African Americans and the Fight for Freedom (Chapel Hill: University of North Carolina Press, 2014), 52-57, 132-134; Kevin Levine, Searching for Black Confederates: The Civil War's Most Persistent Myth (Chapel Hill: University of North Carolina Press, 2019).
} 
Except for nine contrabands and the white soldier, the provost marshal thereafter released the men upon their promise to resume their work. This form of resistance, which at times gained white allies, occurred at every step from enslaved labor to military service. ${ }^{110}$

The discourse of northern governors and Union Army commanders on the utility of black enlistment and which Army positions African Americans should hold captured the range of white wartime racial attitudes. In turn, they illustrated the long emancipation's need for white allies to increase its chances at success. Some whites did not see an important role for blacks in the Army, preferring that they perform fatigue duty to free up combat roles for whites. Others promoted black enlistment in strictly practical terms, as a means of winning the war by depriving Confederacy of slave labor. A third group, however, recognized enlistment's benefits for African Americans themselves. The commander of the Department of Virginia and North Carolina, General Benjamin Butler, issued directives regarding enlistment in December 1863 advising that political and social figures take into consideration "the former condition of the blacks...the new rights acquired by them; the new obligations imposed on them; the duty of the Government to them; the great stake they have in the War." Tackling the issue of discrimination that later sparked mutinies, the general contended that "the colored man fills an equal space in ranks while he lives and an equal grave when he falls." Once ideas for enlistment produced recruitment methods, whites continued to give blacks lessons on the meaning of biracial bonds. ${ }^{11}$ White Union soldiers also expressed racial attitudes that could strengthen or undermine the black struggle for freedom. Ashbel Landon, stationed in Hilton Head, South Carolina,

\footnotetext{
${ }^{110}$ Lt. George F. Woodman to Lieut. Col. Hoffman, February 19, 1863, W-31 1863, Letters Received, ser. 3238, Department of North Carolina and $18^{\text {th }}$ A.C., RG 393 Part 1, quoted in Ira Berlin, et. al., The Black Military Experience, 129.

${ }^{111}$ Samuel J. Kirkwood to General Henry W. Halleck, August 5, 1862, K-493 1862, Letters Received, Series 22 , RG 108 (S-29), quoted in Ira Berlin, et. al., The Black Military Experience, 85-86; General Orders No. 46, Head Quarters Dept. of Va. and North Carolina, December 5, 1863, Vol. 52 VaNc, General Orders Issued, Series 5078, Dept of VA and NC, RG 153 Pt. 1 (C-3062), quoted in Ira Berlin, et. al., The Black Military Experience, 135-138.
} 
described how black troops in his department "make excellent soldiers and will fight like tigers." Meanwhile, as another white soldier put it in the weeks after the issuing of the full Emancipation Proclamation, presumably due to the common white northern fear of an exodus and resulting job competition, "freedom of slaves would be a greater curse to the north than slavery is to the nation." Commenting on a black unit in his camp, Captain Ralph Buckley argued that nothing, even weapons and uniforms, would elevate black troops above the position of "baboons."112

Due to this hostility, the white supremacist type of racially motivated mutinies at times characterized Union Army race relations. In July 1862 Major Edward Bacon led a revolt among three fellow officers of the Sixth Michigan Infantry as the unit was stationed in Baton Rouge. The mutineers refused to obey an order "to deliver up fugitive slaves." The conservative white Unionist troops of Kentucky rebelled against the Emancipation Proclamation, with numerous officers resigning and rank-and-file soldiers deserting. The men of the Twenty-fourth Kentucky Infantry rejected an order to withdraw from Frankfort, requiring the Forty-fourth Ohio Infantry to place their border state comrades aboard cars under the threat of the bayonet. ${ }^{113}$ Such racial attitudes filtering into the USCT officer corps eventually caused mutinies among black troops for the opposite reason: to expand, not contract, African-American rights. When whites treated them like baboons, they felt the need to act like tigers.

Despite the black dreams for a biracial democracy, as the federal government launched its black enlistment agenda in 1863, African Americans learned that this policy also had aspects that violated their personal autonomy. Though the Union Army barred black recruits during the first

\footnotetext{
${ }^{112}$ Diary of Ashbel Landon, June 1863, William Gladstone Collection, Box 1, USAHEC (first quote); "Dear Brothers," January 27, 1863, Ibid. (second quote); Diary of Ralph Buckley, September 1864, Ibid. (third quote).

${ }^{113}$ Edward Bacon, Among the Cotton Thieves (Detroit, MI: Free Press, 1867), 13, 25-26 (quote on 25); Victor Howard, Black Liberation in Kentucky: Emancipation and Freedom, 1862-1884 (Lexington, Kentucky: University Press of Kentucky, 1983), 33-35.
} 
two years of the war, the latter half of the conflict brought the other extreme: the coercion of blacks who did not desire to serve. Like the impressment of civilian contraband labor, the ways in which whites conscripted blacks into the Union Army shed light on the twilight zone between freedom and slavery in which Civil War-era African Americans found themselves. Any man who refused to enlist suffered a range of punishments from officials: harassment, assault, imprisonment, or even execution. One white official wrote a grim September 1863 report in which he laid out the counterproductive nature of conscription: blacks "have lost, not gained, by the proclamation of the President. They are, nominally, free, but in reality, the most unprotected of serfs." 114 On this issue, white Americans had common cause with blacks; whites resented the national conscription laws of both warring republics during the war. Yet, African Americans viewed the draft through the lens of their struggle for racial equality. ${ }^{115}$

In a September 1863 letter written in the context of these problematic Union policies, an anonymous New Orleans resident provided a more bitter black opinion on the war's racial effects. The author, identified only as "A Colored Man," declared that blacks have a "rebel master and a union master." The former desired black labor to grow crops without compensation; the latter wanted it to fight battles under white officers for money and the Union. White officers only desired the monetary compensation, making them "Slave holders at heart." The author explained how blacks sought "liberty," which "must take the day nothing Shorter." "A Colored

\footnotetext{
114 J. Lofficial et. al. to Lieutenant Colonel Pardee, November 1863, P-174 1863, Letters Received, Series 1920, Civil Affairs, Department of the Gulf, RG 393 Pt. 1 (C-716), quoted in Ira Berlin, et. al., The Black Military Experience, 159-161; Benjamin F. Flanders to Major General N. P. Banks, September 26, 1863, Letters Received, Series 1756, Department of the Gulf, RG 393 Pt. 1 (C-535), quoted in Ibid., 158-159; Lieutenant George H. Hanks to Major General N. P. Banks, August 5, 1863, H-91 1863, Letters Received, Series 1920, Civil Affairs, Department of the Gulf, RG 393, Pt. 1 (C-533), quoted in Ibid., 151-152.

${ }^{115}$ For scholarship on white northern and southern resistance to Civil War conscription, see Iver Bernstein, The New York City Draft Riots: Their Significance for American Society and Politics in the Age of the Civil War (Oxford: Oxford University Press, 1990); Mark A. Weitz, More Damning than Slaughter: Desertion in the Confederate Army (Lincoln: University of Nebraska Press, 2008).
} 
Man" wondered whether blacks will return to slavery regardless of the war's outcome. While African Americans appealed to their patriotism with whites, according to the author, blacks "care nothing about the union," for "we have been in it Slaves over two hundred And fifty years."

Such repulsive treatment made African Americans wonder about the state of the emancipation process. A number of blacks could not help but notice similarities between the racism of whites on both sides of the Civil War. The Union cause had shifted in an emancipationist direction, but its armed forces continued to uphold a familiar racial hierarchy. Nevertheless, they remained dedicated to converting the United States into a biracial democracy. With their cherished rights to personal and family autonomy under assault, blacks concluded that the envisioned freedom that motivated them to potentially sacrifice for a new Union without slavery remained unattainable under their new northern "masters."

Regardless of the recruitment method, once black men entered the U.S. Army, they encountered a host of additional violations of their freedom that made resistance desirable, just as it had under slavery, in wage labor, and during the Union's evolving enlistment policy. To be sure, a number of white officers fully or partially recognized their humanity. As the triumphalist school of emancipation historiography has noted, the USCT officer corps drew segments of New England's abolitionist and other idealist social reform movements. Among the less progressive, seeing slavery's horrors firsthand, serving alongside black men, and recognizing their bravery under fire converted white officers to the view that black soldiers had proven their manhood and earned their freedom. ${ }^{117}$ However, the phenomenon of black Civil War soldier mutinies vividly

\footnotetext{
116 "Statements of a Colored man and one of the union Colored friends," September 1863, enclosed in Lieutenant Colonel Jas. A. Hopkins to Brigadier General James Bowen, September 2, 183, H-99 1863, Letters Received, Series 120, Civil Affairs, Department of the Gulf, RG 393 Pt. 1 (C-704), quoted in Ira Berlin, et. al., The Black Military Experience, 153-157; Christopher Hager, Word by Word, 2-4.

${ }^{117}$ Adjutant General Lorenzo Thomas to Edwin Stanton, November 7, 1854, L. Thomas Letters Sent, Generals' Papers and Books, Series 159, RG 94 (V-44), quoted in Ira Berlin, et. al., The Black Military Experience, 169-172;
} 
exposed the darker side of officer-enlistee relations in the USCTs, which the triumphalist school overlooks or downplays. Harmful Army policies, along with the conservative attitudes of numerous white officers, sparked the next chapter of black rebellion.

A range of injustices violated uniformed black men's commitment to live free of white coercion, achieve economic independence, and enjoy control over their labor. The controversy over pay centered on the U.S. Army's practice of paying blacks (\$10) three dollars less than whites (\$13), along with withholding money for clothing, which brought their net wage down further to $\$ 7$. Thus, white troops made almost double their black counterparts. Also, certain officers made excessive use of corporal punishment. These experiences and black men's responses to them within the Union Army's combat forces mirror, and constitute an outgrowth of, the ordeals of civilian contrabands. After the physical abuse and unpaid labor of slavery, insufficient compensation in wage labor, and coercive military policies, African Americans faced another slate of obstacles to the emancipation process' completion. However, at every step of the way, sympathetic whites defended accused mutineers and/or prevent mutinies from happening.

USCTs added to the developing tradition of black resistance through mutiny. Putting on a blue uniform and carrying firearms gave African-American men greater collective strength and leverage than that enjoyed by slaves, wage laborers, and contrabands. It was not enough that black men received permission to serve in the land-based armed forces; such a major victory for the black freedom struggle meant little if the same injustices that long plagued black civilian life characterized Army race relations as well. Just as strikes and truancy did in civilian life and noncombat military functions, mutinies tried to root out injustices in Army camps. Such overt acts of resistance against insufficient and discriminatory compensation mostly involved work stoppages,

Joseph Glatthaar, Forged in Battle; Chandra Manning, What This Cruel War Was Over: Soldiers, Slavery, and the Civil War (New York: Knopf, 2007). 
refusing to do one's prescribed labors and other duties in order to force superiors to correct those wrongs that sparked rebellion. Compelling white superiors to make these corrections was essential for the blacks' emancipation goals to shift from abstract dream to concrete reality.

What stands out in the condemnations of the Union Army's racially discriminatory pay policy that eventually led to revolt in the ranks is a multi-layered set of grievances. USCTs endured not just insufficient pay with which they could not adequately support their families, but an insult to this injury: being paid less than a white comrade represented a betrayal by the government and thus an indignity beyond the mere financial element; it symbolized that the government viewed them as inferior. The pain of both poverty and demoralization launched a protest campaign. As African-American troops and their families continued to endure such injustices, eventually some acted in more insubordinate, militant ways. In doing so, they publicized injustices, telling the government that equal compensation had deeper importance. ${ }^{118}$

Northern governors and other officials captured white attitudes towards unequal pay. The racially progressive recognized wage discrimination as a violation of both the terms of USCT enlistment and the law. May 1863 saw Governor John A. Andrew of Massachusetts proclaim to a Virginia Assistant Superintendent of Contrabands that "Unless they are paid like other troops then they will have been cruelly misled." In the summer of 1863, a frustrated Ohio Governor David Tod demanded from Secretary Edwin Stanton authorization to recruit a black regiment under the July 1861 enlistment law that paid U.S. soldiers thirteen dollars. For him, the pay issue was “an insurmountable objection.” On October 3, 1863, Major John C. Chadwick pointed out that a speedy fix of this injustice was needed to forestall the sowing and rooting of "the seeds of

${ }^{118}$ See the letters of black soldiers to the Christian Recorder, August 27, October 8, 1864, January 14, 1865. 
discord and discontent. ${ }^{" 119}$ Meanwhile, others, such as a Captain O. Brown, preached the need to avoid fostering freedpeople's "dependence upon Government or upon charity." White Federals became annoyed with criticism of public compensation for black families even after the establishment of pay equality in the summer of 1864 . While black soldiers could rely on white allies, they also needed to contend with those less sympathetic towards their poverty. ${ }^{120}$

Black troops themselves, along with kin, expressed their views on the pay issue to the federal government. In their letters, they made clear their expectations about military service and how they often failed to measure up to reality. The longer the unequal pay system remained in place, the more the Federals' Sable Arm appeared to be dangerously close to a state of mutiny. Some petitioners placed themselves within social hierarchies to defend a just pay scale. In September 1863, Corporal James Gooding of the Fifty-fourth Massachusetts, writing to President Lincoln, asked regarding unequal pay, “Are we Soldiers, or are we Labourers"? According to Gooding, since lifelong freemen like himself had the "advantage of thinking, and acting for ourselves," they desired compensation as soldiers, not “menial hierlings." Similarly, in July 1864, Orderly Sergeant George Hatton of the First USCI proclaimed unequal pay as something "no man but the poor, down-trodden, uneducated, patriotic black man would be willing to fight

\footnotetext{
119 John A. Andrew to John Wilder, May 23, 1863, Negro in the Military Service, p. 1264-1265, Series 390, Colored Troops Division, RG 94 (B-455), quoted in Ira Berlin, et. al., The Black Military Experience, 369-370; David Tod to E. M. Stanton, June 26, 1863, Edwin M. Stanton to Governor Tod, June 27, 1863, Telegrams Collected by the Office of the Secretary of War, RG 107 (L-210), David Tod to E. M. Stanton, July 14, 1863, Telegrams Collected by the Office of the Secretary of War, RG 107 (L-200), David Tod to E. M. Stanton, July 18, 1863, Telegrams Collected by the Office of the Secretary of War, RG 107 (L-200), Ibid., 370-371; Statement by Major Jno. C. Chadwick, October 3, 1863, C-242 1863, Letters Received, Series 360, Colored Troops Division, RG 94 (B-32), quoted in Ibid., 383-384.

${ }^{120}$ Captain O. Brown to Major George J. Carney, December 9, 1864, enclosed in Lt. Col. Horace Porter to Brevet Major General John W. Turner, March 24, 1865, V-87 1865, Letters Received, Series 12, RG 94 (K-118), quoted in Ira Berlin, et. al., Wartime Genesis of Free Labor: The Upper South, 207-212.
} 
for." Both men elevated their status above that of wage laborers, which under republican

ideology disqualified them from citizenship because it entailed dependence on someone else. ${ }^{121}$

Other African-American petitioners and their families emphasized their loyalty to the Union, the government's contractual obligations to them, and the material suffering low pay inflicted on families. Corporal Gooding also claimed that blacks deserved equal pay because he and his comrades had performed all their duties and have joined white Unionists in painting "the ground with blood, in defense of Union, and Democracy.” In October 1863, a father of a New Yorker drafted in July demanded to know from Secretary Stanton why his son was being paid less than whites. It was difficult for his son to endure this injustice, since he was dedicated to faithfully serving his country "like a man." During the first half of 1864, the wives of the enlisted men in the Fifty-fourth and Fifty-fifth Massachusetts lamented their various sufferings resulting from financial deficiency: children dying of the families' inability to afford food and medical care, and wives being "untrue to their husbands" and abandoning their children. Therefore, these impoverished wives encouraged their husbands to desert and return home. ${ }^{122}$

Amidst the wave of protest and petition in 1863 and 1864, USCT commanders worried about more hostile reactions to the reviled discriminatory pay system. Days prior to their unit's

\footnotetext{
${ }^{121}$ Corporal James H. Gooding to Abraham Lincoln, September 28, 1863, enclosed in Harper and Brothers to Abraham Lincoln, October 12, 1863, H-133 1863, Letters Received, Series 360, Colored Troops Division, RG 94 (B-408), quoted in Ira Berlin, et. al., The Black Military Experience, 385-386; "George W. Hatton, Orderly Sergeant, First USCI, Hampton Virginia Hospital, July 1, 1864,” Christian Recorder, July 16, 1864, quoted in Edwin S. Redkey, A Grand Army of Black Men, 256-257. However, the record shows that Gooding was actually born a slave. He likely claimed free birth to distance himself from the dependence associated with bondage.

${ }^{122}$ Corporal James H. Gooding to Abraham Lincoln, September 28, 1863, enclosed in Harper and Brothers to Abraham Lincoln, October 12, 1863, H-133 1863, Letters Received, Series 360, Colored Troops Division, RG 94 (B-408), quoted in Ira Berlin, et. al., The Black Military Experience, 385-386; Samuel Roosa to Abraham Lincoln, January 24, 1864 (1865), filed with P-133 1865, Letters Received, Series 360, Colored Troops Division, RG 94 (B181), quoted in Ibid., 477-479; Aaron Peterson to Edwin Stanton, October 29, 1863, P-98 1863, Letters Received, Series 360, Colored Troops Division, RG 94 (B-40), quoted in Ibid., 374-375; Brigadier General A. Schimmelfennig to Captain W. L. M. Burger, June 2, 1864, Volume 58 DS, 148-149, Letters Sent, Series 2413, Northern District, Department of the South, RG 393 Pt. 2 No. 145 (C-1672), and Colonel Alfred S. Hartwell to the Secretary of War, June 13, 1864, H-407 1864, Letters Received, Series 360, Colored Troops Division, RG 94 (B-399), quoted in Ibid., $397-400$.
} 
mutiny in November 1863, the commissioned officers of the Third South Carolina brought attention to the issue. They found no legislative justification for the discriminatory pay scale. They also recognized that it constituted "the cause of much grievance to the colored Troops of this Command." The Third's leadership requested restoration of the rations promised for the men's impoverished families until they receive a raise. In June 1864, Lieutenant Colonel Fox expressed concerns about a potential mutiny involving his men in the Fifty-fourth Massachusetts, which, he worried, would result in the disarming and imprisonment of the whole regiment. ${ }^{123}$ As tensions boiled over, officers could see a mutinous storm on the horizon.

In between formal petitions and outright mutiny, a number of USCTs engaged in actions that disrupted the regular order of military life while still not directly threatening their white officers' authority. Some behaviors fell within the realm of legal protest. Meanwhile, others constituted a crime but of a less serious nature than mutiny, inciting mutiny, or mutinous conduct. However, they all suggested the lengths blacks would take to show their displeasure against prejudice during a crucial period in the history of their race.

Black officers of the Louisiana Native Guard regiments resigned from their positions. For these socioeconomic elites, who previously earned between $\$ 60$ and $\$ 45$ depending on rank, the hated $\$ 7$ represented a major demotion. In March 1863, Lieutenant Robert H. Isabelle explained how spending five or six months in the blue uniform made him conclude that "the same prejudice still exists and prevents that cordial harmony among officers which is indispensable for

\footnotetext{
${ }^{123}$ Lieutenant Colonel Aug's. G. Bennett to Captain Wm. L. M. Burger, November 30, 1863, and Colonel Wm. B. Barton to Brigadier General R. Saxton, December 5, 1863, Twenty-first USCI, Regimental Books and Papers USCT, RG 94, NARA, quoted in Ibid., 388 (quotes); Circular, Headquarters Fifty-fifth Massachusetts Volunteers, June 14, 1864, Negro in the Military Service, 2623-2624, Series 390, Colored Troops Division, RG 94 (B-474), quoted in Ibid., 400-401; Brigadier General A. Schimmelfennig to Captain W. L. M. Burger, June 2, 1864, Volume 58 DS, 148-149, Letters Sent, Series 2413, Northern District, Department of the South, RG 393 Pt. 2 No. 145 (C1672), and Colonel Alfred S. Hartwell to the Secretary of War, June 13, 1864, H-407 1864, Letters Received, Series 360, Colored Troops Division, RG 94 (B-399), quoted in Ibid., 397-400.
} 
the success of the army." Isabelle lambasted northern Federals who assumed that every African American in New Orleans was a contraband. He detailed how well-educated, economically successful, and cultured the city's elite blacks were. Isabelle defended the patriotism of men, like him, who left their prosperous lives to keep Louisiana in the Union. They had been willing, he added, to fight anywhere despite waiting in vain for a pay check and learning of the proclamation from C.S. President Jefferson Davis designating black troops the equivalent of rebellious slaves. His patience had run out. Thus, the U.S. Army's controversial pay policy did not just prevent most African-American men from escaping the bottom of the social ladder despite their escape from slavery, but also threatened to bring well-to-do blacks down to a lower-class status. ${ }^{124}$

The Louisiana Native Guard resignations add a layer of complexity to how black resisters in the Union Army viewed freedom and emancipation. The wealthy blacks of New Orleans who received commissions long before the large-scale enlistment of black soldiers in the Union Army were further along in the emancipation process. Yet, upon assuming their duties, the Native Guards found themselves in a similar position as any member of the Sable Arm. To their consternation, commanders used them for fatigue and guard duty, and they faced hostility from white comrades. However, men like Lt. Isabelle demonstrate that elite African Americans sometimes appealed to common class interests with white Union officers as a means of improving their social status when it suited them. By the full onset of black Army enlistment in early 1863, the Union removed most of the Native Guards' founders.

Closer to the level of mutiny were instances when USCTs deserted rather than serve under a problematic compensation policy. While a serious military crime, unlike mutiny,

\footnotetext{
124 "Robert H. Isabelle, Lieutenant, Second Louisiana Native Guards (Seventy-fourth USCI), New Orleans, Louisiana, February 25, 1863," Weekly Anglo-African, March 14, 1863, quoted in Edwin S. Redkey, A Grand Army of Black Men, 249, 251-252.
} 
desertion entailed escaping injustices rather than forcing their superiors to resolve them. A deserter from the First Louisiana Native Guard received a six-year sentence at Tortugas, Florida. Private Warren D. Hamelton justified his offense in a petition for release in May 1865, arguing that he violated his terms of enlistment because the government had already done so by denying him full payment of what it promised him. He explained his need to support his aging mother and emphasized that he found no legal way to redress his grievances. As a brigade commander noted in the summer of 1864 , black soldiers from the South Carolina coast who served in operations against Charleston and Virginia "deserted by the score because their families were starving" from the combined effects of crop failure, ration cuts, and unreliable, low pay. On June 22, 1864, musician Charles Brown of the Sixty-first USCI deserted for a better-paying job on a steamer. In mid-August, a patrol captured Brown. A court-martial sentenced him to one year of hard labor with a ball and chain and a forfeiture of pay. USCT soldiers who deserted resisted in a method comparable to those of antebellum bondspeople who fled to the North. ${ }^{125}$

Despite a widespread, robust campaign of protest, the numerous critics of the federal government's decision to pay USCTs less than white personnel found their worst fears justified. Beginning in the fall of 1863 and continuing into the spring of 1864, rank-and-file disaffection with the policy escalated to the most overt types of revolt. Since these forms of rebellion risked extreme disorder, they brought the full wrath of the Army's criminal justice system.

\footnotetext{
${ }^{125}$ Warren D. Hamelton to E. M. Stanton, May 1865, H-285 1865, Letters Received, Series 360, Colored Troops Division, RG 94 (B-139), quoted in Ira Berlin, et. al., The Black Military Experience, 384-385; Ira Berlin, et. al., The Wartime Genesis of Free Labor: The Lower South, 110; Proceedings of a GMC, Trial of Charles Brown, LL-2699, RG 153, NARA. In the same file is the case of Vicksburg-based Private Sam Jeffers of the Third USCC, who also deserted the Army to work on a civilian steamer in 1864. For a postbellum USCT who deserted his unit to become a civilian sailor, see OO-1589, Trial of Private Albert Williams, $117^{\text {th }}$ USCI. For select works on slave flight, see John Hope Franklin, Loren Schweninger, Runaway Slaves: Rebels on the Plantation (New York: Oxford University Press, 1999); Cheryl Janifer LaRoche, Free Black Communities and the Underground Railroad: The Geography of Resistance (University of Illinois Press, 2013); Donald George Simpson, Under the North Star: Black Communities in Upper Canada Before Confederation (Trenton: Africa World Press, 2005).
} 
Just as enslaved and free black workers antagonistically challenged miserable and otherwise undesirable conditions in antebellum American society and in Union contraband camps, USCTs facing similar realities took matters into their own hands. Since their superiors chose to pay them less than white soldiers as they risked losing their lives, limbs, and/or sanity battling Confederates and maintaining fortifications, failing to fulfill a core component of the bargain of black enlistment, a number of USCTs concluded that they were not obligated to follow the requirements of military service. Therefore, they put down their arms while in camp or stayed silent during a muster. Taking the form of work stoppages, mutinies against unequal pay, both in motivation and in tactics, resembled labor strikes in which civilian workers dropped their tools and neglected their tasks until their employers agreed to their demands. Because these confrontational, yet non-violent, examples of insubordination challenged the authority of superiors, undermining the hierarchical structure and regular course of Army life, the white officer corps deemed them to be as serious as the forceful and violent variety. ${ }^{126}$

Both the South's former slaves and free black northerners chose mutiny to vent their sense of betrayal and general frustration against being paid less than white comrades. Southern USCT mutineers drew from slave resistance, interpreting injustices from the Army in a similar light as those of their masters. Meanwhile, black northerners brought to the Army life-long, cross-generational frustrations over their own section's racism. While legally free, they could not vote, lived amidst occasional race riots, and had fewer economic opportunities. While they did not know slavery first-hand, they would have been familiar with runaway slave narratives,

\footnotetext{
${ }^{126}$ Edwin S. Redkey, A Grand Army of Black Men, 229; Proceedings of a GCM, Trial of Sergeant William Walker, MM-1320, RG 153, NARA; Lieut. Col. Augustus G. Bennett to Captain William L. M. Burger, November 30, 1865, enclosed in Col. William B. Barton to Brig. General R. Saxton, December 5, 1863, Letters Received, $21^{\text {st }}$ USCI, Regimental Books and Papers USCT, RG 94, quoted in Ira Berlin, et. al., The Wartime Genesis of Free Labor: the Lower South, 274-275; Price Warefield et. al. to E. M. Stanton, February 20, 1865, filed with S-196 1865, Letters Received, Series 360, Colored Troops Division, RG 94 (B-150), quoted in Ira Berlin, et. al., The Black Military Experience, $459-460$.
} 
abolitionist rhetoric, and the fear of enslavement from enforcers of the 1850 Fugitive Slave Law. Moreover, those growing up amidst or after northern emancipation knew more than southern exslaves about the need for continued resistance to further the black liberation process.

The various backgrounds of black mutineers certainly played direct or indirect roles in their actions, but the end result—the specific mutinous actions—often blurred these boundaries. Individual preference and the circumstances of a particular unit's camp tended to determine whether a northern or southern member of the USCT revolted and in what manner. An important aspect of these shared qualities among northern and southern blacks was that they performed identical labors and duties as soldiers in the Union Army regardless of their upbringing. All African-American Federals were more likely than whites to serve in less glorious, noncombat roles and receive inferior provisions. Both northern and southern black troops came from heavily impoverished communities, with the former residing in the bottom tier of the working class and the latter owning little more than the clothes they wore. Thus, military service weakened the distinctions among black men of different socioeconomic and cultural worlds. The recently liberated and those born free alike thus had similar responses to shared injustices. ${ }^{127}$

On November 19, 1863, while stationed at Hilton Head, the troops of Company A, Third South Carolina Infantry, launched one of the first major USCT mutinies against the pay issue. Their regiment consisted of former slaves who had experienced the peculiarities of bondage in the Palmetto State. While Upper and Border South USCTs originated from a region decreasingly dependent on large-scale agriculture and thus more populated with small enslaved labor forces and free blacks, black South Carolinians lived in a society based on huge rice and cotton plantations and the largest farms of the mid-nineteenth century, a function of its semitropical

${ }^{127}$ Ira Berlin, et. al., The Black Military Experience, 362-363. 
climate and its colonial origins as an extension of the West Indies. Gullah backgrounds and isolated plantations made enslaved South Carolinians more culturally homogenous, and they formed part of a large black majority in the state, which the domestic slave trade boosted. ${ }^{128}$

The Third's enslaved background suggests indirect determiners for why the unit's troops engaged in mutiny. Since Union Army employment and military service represented their first taste of free labor, unleashing the Civil War's social revolution, the mutineers could not let the emancipation process' momentum slow down via pay discrimination. Also, the large plantations on which they labored prior to the war would have taught them the power they possessed in collective numbers, even more so now that they were uniformed and armed. ${ }^{129}$

The existence of the Third South Carolina owed to Union operations along the Atlantic coast as well as the large African-American population of eastern South Carolina, especially the Port Royal area, making it the birthplace of wartime Reconstruction. In November 1861, General David Hunter's forces invaded this area. With planters fleeing, blacks flooded into the Unionoccupied Sea Islands. Over the next year, after losing forces to relocation in the summer of 1862, U.S. commanders weighed black enlistment proposals. Finally, amidst the dawn of the Federal black recruitment policy following the Emancipation Proclamation, infantry regiments emerged in the Palmetto State. The Third South Carolina began its duties on June 19, 1863. In the months leading to their mutiny, its members performed garrison duty at Hilton Head. Doing monotonous labor like coaling ships caused Company A's men to become so exhausted that their commander reported in early August that "My men are giving out." Despite previous promises by the

\footnotetext{
${ }^{128}$ Susanna Ashton, I Belong to South Carolina: South Carolina Slave Narratives (Columbia: University of South Carolina Press, 2010), 2-3.

${ }^{129}$ Ira Berlin, et. al., The Black Military Experience, 25.
} 
secretary of war that South Carolina's USCTs would earn the same thirteen-dollar monthly wage as white units, the government paid them the hated seven dollars. ${ }^{130}$

The Third South Carolina's Company A believed that unequal pay during their time of service grossly violated the emancipation process. Sergeant William Walker acted as their ringleader. A runaway slave, Walker made the mistake of moving from the more racially progressive Navy to the Army on the word of several officers that the pay would be equal among all volunteers. As the previous chapter indicated, had he remained a sailor, he likely would have never participated in a mutiny. Sergeant Walker led the company in stacking their weapons and ammunition and marching to their commander, Lt. Colonel Augustus G. Bennett. When Bennett inquired into what was occurring, Walker informed him that the mutineers were "not willing to be soldiers for seven dollars per month." The lieutenant colonel informed the men that they had violated Army regulations and ordered them to resume their duties. Instead, they returned to their quarters, leaving their arms behind. The next day, commissioned officers arrested Walker, demoted him to private, and tried him for mutinous and ill-disciplined conduct. ${ }^{131}$

Sergeant Walker's testimony during his court-martial clearly illustrated the gap between USCTs' expectations and realities regarding their service as it related to their freedom, as well as how the resentment over unequal pay could combine with other grievances to form a powder keg of emotions. Walker contended that ninety percent of his unit's officers had acted "tyrannical in

\footnotetext{
${ }^{130}$ Ira Berlin, et. al, Wartime Genesis of Free Labor: Lower South, 87-113; Ira Berlin, et. al., Black Military Experience, 37-41; Captain to Col. Bennett, August 3, 1863, Twenty-first USCT Regimental Papers, Box No. 21, Office of the Adjutant General, RG 94, NARA.

${ }^{131}$ Quoted in Edwin S. Redkey, A Grand Army of Black Men, 229. Walker previously served as a gunboat pilot. While on furlough to visit his family, he learned the false promise of equal pay in the Army. It is still not apparent in why he deemed naval service less desirable given the trend of black servicemen taking the reverse course from land to sea duty. Among the few scholarly examinations of Walker's mutiny is Howard C. Westwood, "The Cause and Consequence of a Union Black Soldier's Mutiny and Execution," Civil War History, Volume 31, Number 3, September 1985, 222-236. Westwood also refers to this act as a "strike" and stresses how Walker's execution was illegal because President Lincoln never reviewed the case beforehand.
} 
the extreme, and totally beneath that standard of gentlemanly conduct which we were taught to believe as pertaining to officers wearing the uniform of a government that had declared 'freedom to all' as one of the cardinal points of its policy." Walker testified that such "treatment, prepared the way for the events that occurred when it was announced to us that we could receive but $\$ 7$ per month pay." He tried to persuade the judges that he and his comrades were merely making a "peaceful demand for the rights and benefits that had been guaranteed them." Further, his whole company never received a proper education on Army regulations during the entirety of their terms; they instead had to learn their duties on the job based on informal instructions. ${ }^{132}$

In producing this statement, Sergeant Walker did not only try to convince judges to acquit him as a defendant; he painted for white northerners the collective and individual identities black soldiers had formed while serving together in an army of liberation, as well as also bringing attention to the failures of the white officer corps. Family, which a slave sale could tear apart in an instant and whose stability blacks prioritized as they implemented emancipation, stood at the center of enslaved and freed-people's socio-political worlds during the nineteenth century. Protecting kinship remained paramount as freedpeople entered the free labor system and established their own households. Yet, once former bondsmen enlisted in the Union Army, those circles expanded to include others. Even prior to enlisting, USCTs became part of what Stephen Hahn calls the world's largest and most successful slave revolt — the hundreds of thousands of slaves who helped topple the peculiar institution during the Civil War. Once they performed soldierly duties, black men in blue became comrades who worked together for common military goals while under the command of white officers held to high moral and behavioral standards. When officers fell short of these standards, this camaraderie became one based on shared

132 Proceedings of a GCM, Trial of Sergeant William Walker, MM-1320, RG 153, NARA. 
injustices. In calling his superiors despotic and un-gentlemanly despite serving in an army fighting for egalitarian ideals, Walker framed Army racism as contrary to the Union war effort and the principles for which it was fighting. Further, these men shared the same frustrations and traumas associated with being ex-slaves who now encountered a form of white northern racism and a violation of the terms of their service. The sentiments boiled over to such an extent that the men withdrew their side of the bargain, stacking up their arms. In doing so, they sought to fix a system that repeatedly had disappointed African Americans struggling to establish a biracial democracy during the trajectory from bondage to enlistment. ${ }^{133}$

In addition to his physical actions, Sergeant Walker highlighted this identity through his use of the plural words "we" and "them" while detailing their insufficient pay and training. Though he himself was on trial as the ringleader, he communicated the collective motivations and widely shared circumstances that bred the incident in question. They all felt the pain of struggling to support their impoverished families while undergoing the added insult of discrimination. Also, he spoke of his comrades as a group distinct from the white officers, while also empathizing with the latter. Both the black rank-and-file and white officer corps responded to the situation according to their own vantage points. The collective identity indicated by his plural language foreshadows future developments in African-American life. Blacks' collective identities continued to expand in the postbellum years, through the formation of political clubs, farming cooperatives, labor unions, churches, and the Buffalo Soldiers. Despite the frequency of individual black soldiers' revolts, the welter of episodes in which groups of black men conducted

\footnotetext{
${ }^{133}$ Stephen Hahn, A Nation Under Our Feet, page number; cite camaraderie in USCT scholarship.
} 
a rebellion together signifies that African Americans throughout the emancipation process were developing an elaborate web of collective identities. ${ }^{134}$

A letter by Lt. Colonel Augustus Bennett, commander of the Third South Carolina, to a captain, and later forwarded to Brigadier General R. Saxton, sheds more light on the context for the mutiny of Sergeant Walker and his comrades. Writing on November 30, 1863, Bennett brought attention to how his men's seven dollars a month made them "unable to render the least assistance towards the support of those who are depended on them.” Therefore, Bennett recommended that soldiers' families, who "are in a deplorable condition," should receive rations. Also, "great dissatisfaction" permeated the regiment because of knowledge that black workers employed in the quartermaster department earned between ten and twenty-five dollars and because these workers' families enjoyed rations. However, according to Saxton, these rations would breed dependence on the government, and he disagreed with the notion that families whose husbands and fathers earn seven dollars a month could be "destitute."135

The origins of the Third South Carolina's mutiny were also not confined to resentment against unequal pay. A revealing June 1864 letter from Colonel M. S. Littlefield, the superintendent of black recruitment in the Department of the South, to the department's provost marshal documented miserable circumstances the regiment endured. From the time of their enlistment in the spring of 1863, the former slaves in the unit endured a harsh existence which likely played a role in further inflaming tensions in the ranks. According to Littlefield, men like Sergeant Walker began their terms with inadequate clothing, "little or no instruction," and

\footnotetext{
${ }^{134}$ For a thorough analysis on how freedpeople's plural language represented the formation of a more collective identity, see Christopher Hager, Word by Word, 8-9, 107-137.

${ }^{135}$ Lt. Col. Augustus G. Bennett to Captain William L. M. Burger, November 30, 1863, enclosed in Col. William B. Barton to Brig. General R. Saxton, December 5, 1863, Letters Received, $21^{\text {st }}$ USCI, Regimental Books and Papers USCT, RG 94, quoted in Ira Berlin, et. al., The Wartime Genesis of Free Labor: The Lower South, 274-275. Saxton only permitted rations for contrabands lacking familial support.
} 
incompetent officers who had since left the unit. The colonel noticed that by the time of writing his letter, the recent arrival of exceptional officers, who replaced the "worthless" ones and properly guided the troops, had improved the quality of the regiment. ${ }^{136}$

As the black Army experience shows, poor white leadership increased the likelihood of black rank-and-file revolt. Even before they received their first seven-dollar payment, the Third South Carolina's mutineers felt a variety of negative emotions that intensified when whites lied to them about their compensation. Linking the letters from Bennett and Littlefield with Walker's testimony, one can add sympathetic whites to the socio-political lives of formerly enslaved soldiers. In addition to relying on each other to advance the cause of emancipation, African Americans at times enjoyed examples of whites helping them build a biracial democracy.

The William Walker court-martial established trends in the phenomenon of black military mutinies which would characterize them throughout the long emancipation: mutineers took grave risks to their lives and well-being; and while some white officers sympathized with black mutineers' motivations enough that they advised leniency, others strictly enforced Army regulations. The judges found Walker guilty, giving him the death penalty. In an appeal letter, Colonel Littlefield acknowledged the Army's violation of numerous terms of service. $\mathrm{He}$ contended that since the mutineers were ignorant of the illegal nature of their action, they did not technically commit a crime. As the colonel understood it, the receipt of half of their promised pay told troops that they were no longer obligated to perform their duty. ${ }^{137}$

Walker's mutiny ultimately cost him his life. Despite the appeal, the Army executed him by firing squad on March 1, 1864. In doing so, the Army made an example out of him as the

\footnotetext{
${ }^{136}$ Proceedings of a GCM, Trial of Sergeant William Walker, MM-1320, RG 153, NARA.

${ }^{137}$ Colonel M. S. Littlefield to Colonel P. P. Brown Jr., June 3, 1864, Letters Received, Twenty-first USCI, Regimental Books and Papers USCT, RG 94 (G-81), quoted in Ira Berlin, et. al., The Black Military Experience, 391-395.
} 
ringleader, since nine other soldiers tried for participation in the company's strike received prison sentences. While most convicted African-American mutineers during and after the Civil War escaped capital punishment, Sergeant Walker's case illustrates that any soldier who chose to express his grievances in the most overt, aggressive manner could lose his life. In the case of South Carolina's black regiments and others composed of former bondsmen, the main issue which sparked the November 1863 mutiny would not be solved until March 1865, by which they had received full back pay from the time of their enlistment. Yet, on the other hand, this mutiny showcased the leniency, resolution, and sympathy white commanders could give mutineers. An investigation by the Department of the South in June 1864 argued that the "bad management" of officers was "more to blame than" the mutineers themselves. In the conclusion of their report, the investigators successfully recommended restoring the imprisoned mutineers to duty. Finally, the Third South Carolina's late 1863 rebellion foreshadowed how over the next century, mutinies often constituted the climax of various crises plaguing military race relations and servicemen's well-being for weeks and months leading to the event. ${ }^{138}$

Drawing on understandings of contracts and republican ideology, the abolitionist press offered its own perspectives on black soldier mutinies against unequal pay in general and of Walker's mutiny in particular. The Liberator published an article the following year about the tendency of tyrannical power to deceitfully apply honorable names to favorable entities and persons and dishonorable ones to the unfavorable. As an example, the paper highlighted the word "mutiny," which whites used for black soldiers who revolted against a government that violated its terms of a contract by paying the former late or unequally and denying formal redress of grievances. The execution of an unpaid soldier constituted robbery and murder. Thus, the paper

\footnotetext{
${ }^{138}$ Proceedings of a GCM, Trial of Sergeant William Walker, MM-1320, RG 153, NARA; Edwin S. Redkey, A Grand Army of Black Men, 229-231.
} 
continued, the designation of "mutiny" originated from power obscuring its crimes through phraseology: "The act of killing him for standing thus upon his rights, and doing his part towards the claim of equitable treatment for his people, is called 'the punishment of mutiny." According to the writer, Walker engaged in not mutiny, but "just and manly conduct." His execution therefore highlighted the need for "strong, united, persistent protest, by all who love justice and hate tyranny." ${ }^{139}$ At the time of the Civil War's USCT mutinies, the most vocal supporters of black civil rights understood the broader significance these episodes and the mainstream culture's discourse on them held for the emancipation process.

Episodes between late 1863 and the spring of 1864 involving groups of black northerners showed that the struggle against unequal pay escalated within USCT units raised in the North as well. In addition to the Thirty-second USCI whose experiences opened the current chapter, the Fifty-fourth and Fifty Fifth Massachusetts Infantry regiments declined to accept discriminatory paychecks. While they never stood before a court-martial, they committed actions and made statements that could have led to formal prosecution if they served under stricter officers. With both black Massachusetts units encamped in coastal South Carolina, they shared geographic proximity with the Third South Carolina's ex-slaves at the time of the latter's own rebellion against unequal pay. Though northern and southern troops had metaphorically taken different paths to freedom thus far, USCTs shared the same injustices during their military careers, regardless of background and often physically next to each other.

The enlisted men of the Fifty-fourth Massachusetts "received unfavorably" the news of unequal compensation. Since this discrimination violated the terms under which they enlisted

\footnotetext{
139 "Loyalty-Mutiny," The Liberator, September 2, 1864, "Civil War: Antebellum to Reconstruction, 1843-1877," West Virginia University Libraries, https://infoweb-newsbank-com.www.libproxy.wvu.edu/iwsearch/we/HistArchive/.
} 
and compromised "their self respect," they refused their payment. In a November 1863 letter to Governor John A. Andrews, Colonel E. N. Hallowell expressed his understanding that his men "enlisted because men were called for," not because the government offered them money. They would rather fight for the Union without pay for the entire war than accept such inequality; if they did, he added, then they would "acknowledge that because they have African blood in their veins, they are less men, than those who have saxon."140

When the paymaster refused to issue them an amount exceeding seven dollars in the summer of 1864, members of the Fifty-fifth Massachusetts also rejected their checks. To explain this decision, they wrote the president defending their right to equal pay. They referenced July 1861 legislation under which their unit and white commands had formed that established all soldiers' pay at thirteen dollars a month. As they noted, "to us money is no object"; rather, "we came to fight For Liberty justice and equality. These are gifts we Prise more Highly than Gold." Over the past thirteen months, they had "cheerfully and willingly" performed trench and fatigue duty and demonstrated "conspicuous valor and endurence in Battle." Being paid unequally constituted "Having Been enlisted under False Pretence." The letter concluded by threatening that, "if imediate steps are not taken to Relieve us we will Resort to more stringent measures." 141 The Massachusetts men continued to protest by declining their insulting pay even when in December 1863, their state government offered to make up the federal pay difference to bring it to the level of white soldiers. Since the issue centered on principle rather than money, men in both regiments politely refused the subsidy in order to "wait justice from the proper source."

\footnotetext{
${ }^{140}$ Colonel E. N. Hallowell to Governor John A. Andrew, November 23, 1863, Letters Sent, Fifty-fourth Massachusetts Volunteers, Regimental Books and Papers USCT, RG 94 (G-232), quoted in Ira Berlin, et. al., The Black Military Experience, 387.

${ }^{141}$ Sergeant John F. Shorter et. al. to the President of the United States, July 16, 1864, L-211 1864, Letters Received, Series 360, Colored Troops Division, RG 94 (B-103), quoted in Ibid., 401-402.
} 
Only when Washington, D.C., agreed to pay all Union soldiers equally would they feel satisfied. The seventy-four signers from the Fifty-fifth pointed out that they did not enlist in a system whereby separate levels of governments each paid a component of their wages. This stance persuaded their officers to agree with, and second, their decision. ${ }^{142}$

When they refused payment, the Fifty-fourth and Fifty-fifth Massachusetts could count on the endorsement of their commanders. All grew out of the abolitionist movement: Robert G. Shaw and Edward N. Hallowell, Norwood P. Hallowell and Alfred S. Hartwell, respectively. According to these white allies of emancipation, if the federal government refused to uphold its end of the bargain, it should muster these men out of the service. ${ }^{143}$

However, the Massachusetts officers faced a more difficult situation when the discontent that produced pay refusals and petitions escalated. Observers reported hearing proclamations of "money or blood" and "muster us out or pay us." The unleashing of this mutinous energy led to individual troops and small bands of men in the Fifty-fifth clashing with officers over not just unequal pay, but also their families' poverty, the ban on blacks earning officer commissions, and poor-quality weapons. Officers tried to make disciplinary examples out of these "few malcontents." To deescalate the situation, Colonels Norwood Hallowell and Hartwell tried reassuring their disaffected men that Congress will eventually pass an equal pay law. However, these reassurances often resulted from rumors or inaccurate reports, undermining trust between commanders and the enlisted men. Only the strenuous efforts of black noncommissioned officers to prevent escalation of tensions and the implementation of the June 1864 law in August prevented the simmering degree of tension in the Massachusetts camps from boiling over into

\footnotetext{
${ }^{142}$ Ibid., 366-367; Keith P. Wilson, Campfires Of Freedom, 51, 54.

${ }^{143}$ Colonel Alfred S. Hartwell to the Secretary of War, June 13, 1864, H-407 1864, Letters Received, Series 360, Colored Troops Division, RG 94 (B-399), quoted in Ibid., 398-400.
} 
widespread mutiny. ${ }^{144}$ Perhaps the men of the Fifty-fourth and Fifty-fifth Massachusetts never conducted a full work stoppage against equal pay because there remained a semblance of legal recourse in the form of sympathetic officers who protested on their behalf.

In a demonstration of what could have happened in the Massachusetts camps on the Carolina seaboard, a large-scale mutinous wave among other black northern troops broke out on the other side of the country. In the spring of 1864, after "trouble" had been "brooding for a long time," as an officer later put it, tensions reached a boiling point with two groups of Rhode Island artillerymen stationed in coastal Texas. These two episodes demonstrate that as the federal government continued to allow the unequal pay policy to continue into 1864 , the animosity towards this and related offenses only worsened and spread. ${ }^{145}$

A Rhode Island recruitment poster from late 1863 sheds light on the high expectations of these black artillerymen and in turn, why they felt resentful enough to mutiny when reality dashed these expectations. It advertised the following: "Equal State Rights! And Monthly Pay with White Men!!"; "Freedom to Over Three Millions of Slaves"; and "Protection of Colored Troops." On the second page, the poster denounced claims that blacks would not fight due to natural cowardice: "A viler slander Satan never uttered through the lips of a traitor." To refute such lies, the poster cited twelve engagements in which blacks displayed valor on the battlefield, as well as praise from the president and white officers and soldiers. The poster included a call to its "Colored Citizens." Along with the same $\$ 13$ monthly pay as white troops, the poster promised blacks full support for their families, lifetime pensions for the wounded and for the

\footnotetext{
${ }^{144}$ Keith P. Wilson, Campfires Of Freedom, $55-57$ (quotes). See also Proceedings of a GCM, Trials of Sergeant Sampson Goliah and Privates Young Gouch, John Lewis, Nelson Browning, and Richard Morrison, NN-2479, RG 153, NARA.

${ }^{145}$ Major J. J. Comstock Jr. to Colonel Charles E. Bailey, April 16, 1864, Letters Sent, Eleventh USCHA, Regimental Books and Papers USCT, RG 94, quoted in Ira Berlin, et. al., The Black Military Experience, $395-397$.
} 
families of those killed in battle, and the highest state bounty (\$250). The unit's duty would consist of defending the New England coast from Rebel pirates. The poster concluded by calling on black Rhode Islanders to "rally... around the old flag," suppress "the most wicked rebellion that ever polluted the records of heaven," and to "heed" the "cry" of those still held in slavery. Once soldiers restored the Union and set their brethren free, they could look back on their service with pride. Since everything the poster promised failed to measure up to reality, Rhode Island's black soldiers felt especially betrayed. Not only did they learn that they would receive less pay than white soldiers, but they also found themselves performing fatigue duty in a distant corner of the country, neither defending their local territory nor displaying their capacity for bravery. ${ }^{146}$

After they learned they were to be paid the hated seven dollars a month, those of the first group of mutineers refused to answer their names during a March 17, 1864, inspection, preventing them from mustering. Like the infantrymen of the Third South Carolina and the Fiftyfourth and Fifty-fifth Massachusetts, these members of the Fourteenth Rhode Island Heavy Artillery (RIHA) had enlisted with the understanding that they would hold the same status as white soldiers, which entailed equal financial compensation. In the wake of the violation of this contract, the artillerymen conducted a collective stoppage. Though this differed from the Third South Carolina's stacking of arms, both methods disrupted the regular course of military procedures and told superiors that the rank-and-file were refusing to perform their duties. The noncommissioned officers and twenty privates who perpetrated the act received hard labor prison sentences at Fort Jefferson, Florida, ranging from three months to a year. Major J. J. Comstock,

\footnotetext{
${ }^{146}$ Recruitment broadsides (1863), enclosed in M. R. Delany to Hon. Secry. War, December 15, 1863, D-135 1863 , Letters Received, Series 360, Colored Troops Division, RG 94, printed in Ibid., 103-105.
} 
Jr., who recommended the above charges, deemed the sentences lenient for a mutiny. These Rhode Islanders were fortunate to avoid a death sentence like Sergeant William Walker did. ${ }^{147}$ The tensions that unequal pay unleashed in the Fourteenth Rhode Island persisted into early April. At that point, Lieutenant Potter shot an enlisted man during a confrontation over the issue. In retaliation, a second mutinous group demanded that the lieutenant leave the island and threatened to kill every white officer in the unit. General Dana sent two light batteries and two white regiments to the camp to suppress the disturbance. This force held the entire battalion in custody for twenty-four hours, an action that restored order. In his report of both mutinies, Major Comstock praised Potter's earlier violence and wished that Captain Fry, then in command, had likewise executed the mutineers. According to the major, only a climate of fear will discourage black soldiers from rising up against their white superiors. Thus, some white officers received implied permission to kill any would-be mutineer without prosecution. ${ }^{148}$

More so than the two Massachusetts regiments and the Third Carolina, the Fourteenth RIHA offered a cautionary tale to any white man commanding African-American soldiers during the Civil War and beyond. As Major Comstock failed to realize, when officers instilled a relationship based on respect for their men's freedom and manhood, not oppression and force, disciplinary problems like mutiny dropped in frequency and likelihood. This error in judgment plagued race relations in the segregated U.S. Army during the entire long emancipation era.

As USCTs and white allies fumed over the controversy, tirelessly lobbying a resolution to it and/or outright rebelling against it, the U.S. government finally acted. In June 1864, Congress passed legislation mandating pay equity for all Union soldiers and retroactive back pay for those

\footnotetext{
${ }^{147}$ Major J. J. Comstock Jr. to Colonel Charles E. Bailey, April 16, 1864, Letters Sent, Eleventh USCHA, Regimental Books and Papers USCT, RG 94 (G-57), quoted Ibid., 395-397.

148 Ibid.
} 
black troops who were free when the conflict began. The War Department implemented the act between the late summer and early fall, and by the following year, the attorney general applied the retroactive provisions to all black volunteers. Since they had finally pushed the federal government to accept equality between white and black Union soldiers, celebratory activities took place in USCT camps. To be sure, it was mainly political pressure and knowledge of low morale among the USCTs that finally convinced stubborn congressmen to enact pay justice. Moreover, isolated cases exist of the government failing to regularly and fully compensate the USCT rank-and-file as late as June 1865. Yet, the mutinies against this example of discrimination, along with the threat of additional ones, contributed to the broader pressure against the government to officially resolve the equal pay issue, albeit long after prosecuted mutineers had lost their lives or received a dishonorable discharge. During Congress' debate over equal pay legislation, Massachusetts Senator Henry Wilson, no doubt aware of the equal pay movement among his own state's black troops, cited the Walker mutiny, calling it "impelled by a burning sense of our injustice." However, unlike unequal pay, the second major motivator of black Civil War mutinies did not resolve itself in such a favorable manner. ${ }^{149}$

Just as black soldiers followed the lead of slaves, antebellum free black laborers, and contrabands in disrupting the regular order of their workplace for better material compensation, they also built on longer traditions of black resistance and labor unrest when they rebelled against physical abuse. As labor history has demonstrated, worker uprisings tended to fight for better working conditions as well as for higher compensation. As seen in later chapters, the

\footnotetext{
${ }^{149}$ Keith P. Wilson, Campfires Of Freedom, 56-58, 256, note 43; John C. Rives, The Congressional Globe: The Thirty-eighth U.S. Congress (Washington: Congressional Globe Office, 1864), 1805. A number of individual soldiers never received consistent pay. See George G. Freeman to U.S. Chief Justice, June 25, 1865, Captain E. J. McKendrie to Brigadier General L. Thomas, August 17, 1865, F-155 1865, Letters Received, Series 360, Colored Troops Division, RG 94, quoted in Ira Berlin, et. al., The Black Military Experience, 379-381.
} 
grievance of white cruelty towards blacks links African-American servicemen throughout the long emancipation era. While unequal pay ceased being an issue that triggered mutiny by the end of the Civil War, the USCTs and their successors in the postbellum U.S. Army struggled for decades, with little success, to find a way to end physical harassment and abuse. Growing out of long-and short-term factors - nineteenth-century America's racist culture, the centuries-long white fondness for violently disciplining black bodies to uphold social order, diversity in racial views among the Union high command, and particular officer recruitment policies-the USCTs' own version began with African-American struggles to rid the practice in the armed forces. Slavery's use of the lash to enforce discipline made any form of bloody mistreatment from a white overlord to a black subordinate a serious violation of uniformed soldiers' status. ${ }^{150}$

As with grievances over pay, whether African-American troops felt physically exploited enough to mutiny often depended on the racial attitudes of their white commanders. In May 1865, a soldier in the Twenty-second USCI, then stationed in Chapel Point, Maryland, related to a black newspaper that General Benjamin Butler, commander of the Army of the James, proved to be a white ally in African-American struggles against racism. In contrast, his successor, Edward Ord, struck them with a sword during a parade. The soldier looked back nostalgically on the tenure of Butler: their beloved ex-commander was a "noble patriot and true soldier" who would have prosecuted the offender and provided redress, and who valued his "true and trusty" men's lives. Now, the soldier revealed, protesting the injustice constituted "insubordination." 151 USCTs relied on white allies to realize their hopes regarding military service.

\footnotetext{
${ }^{150}$ For scholarship on the abuse experienced in the lives of enslaved people, see John W. Blassingame, The Slave Community: Plantation Life in the Antebellum South (New York and Oxford: Oxford University Press, 1972), 113, 172, 246, 249-284.

151 “' Observer,' Twenty-second USCI, Chapel Point, Maryland, May 13, 1865,” Christian Recorder, May 27, 1865 , quoted in Edwin S. Redkey, A Grand Army of Black Men, 264-265. Similarly, in August 1864, black correspondent Thomas M. Chester contrasted the Army of the James' treatment of USCTs to that of the Army of the Potomac. The former contained officers like General Birney, who "treats his men as any other gallant officer would regard the
} 
While stationed at Fort Jackson, below New Orleans along the Mississippi River, on December 9, 1863, the Fourth Regiment Infantry, Corp d'Afrique, later known as the Seventysixth USCI, became one of the first black commands to rebel against physical abuse. This unit's uprising resulted from the ways in which the Union Army filled some of its officer positions, the occasionally tense relations between commanders and enlisted men, and the consequences of black Union soldiers disproportionately performing garrison duty. As historians have demonstrated, white northerners preferred relegating African Americans to non-combat roles because of racial views emphasizing black laziness and the black worthiness for only a secondclass type of citizenship. After assaulting and capturing Port Hudson earlier in the summer, the Fourth occupied Forts Jackson and St. Philip between August 1863 and February 1864. Civil War soldiers, black and white, generally resented the unglamorous aspects of fort occupation: construction, maintenance, parades, drills, and guard duty. The boredom resulting from monotonous tasks at forts instead of fighting traitors on the battlefield undermined discipline, which in turn made officers stricter. It further prevented commanders from earning respect gained through battlefield performance among their men. As officers tried displaying their authority exclusively through discipline, enlisted men viewed such treatment as despotic and arbitrary. The cumulative effects of garrison duty exacerbated preexisting socioeconomic class tensions between officers and the rank-and-file, which became ever more acute when race entered the equation. Despite what eventually occurred, according to Major General N. P. Banks, commander of the Department of the Gulf, the regiment was "among the best disciplined and the best instructed regiments of this class of troops." This reputation changed when, as one

defenders of the Union," earning him "enthusiastic admiration"; however, the latter generated fear within Chester that "the kind of men who command" the Army's black troops "has tended to demoralize rather than to inspire them.” See R. J. M. Blackett, Thomas Morris Chester, Black Civil War Correspondent: His Dispatches from the Virginia Front (Baton Rouge: Louisiana State University, 1989), 108-109. 
commander described them, "men disqualified by want of character" flooded the Corps

d'Afrique. This contrasted with other black units that chose officers according to high standards in the areas of training, morality, experience, and abolitionist views. ${ }^{152}$

Like mutinies against unequal pay, the specific grievance of corporal punishment shaped how soldiers revolted against it. First, they mutinied because they observed a gross violation of the terms of service as well as their emancipation. The Louisianans of the Fourth joined the unit with the understanding that they would not suffer from disciplinary punishments suggestive of bondage, such as whipping. Also, the mutineers against this grievance tended to act forceful, loud, and belligerent, making a cycle of retaliatory violence likely. ${ }^{153}$ To be sure, corporal punishment also existed in white Union camps. Yet, the legacy of American racial violence, coupled with the documented racist views of some officers, prevented the USCT rank-and-file from separating the draconian nature of military discipline from slave lashings and race riots.

Prompting members of the Fourth Regiment to mutiny in late 1863 along the Mississippi were the brutal actions of one such white officer recruited from the pool of those deficient in character. Lieutenant Colonel Augustus W. Benedict whipped two drummer boys, Harry Williams and Munroe Miller, who had entered the sentinel and reported that the sergeant of the guard had permitted them to leave. When Colonel Charles R. Drew, who had a reputation for abuse, neglected to intervene, half of the regiment charged into the parade grounds. ${ }^{154}$

\footnotetext{
${ }^{152}$ Fred Harvey Harrington, “The Fort Jackson Mutiny,” Journal of Negro History 27, no. 4 (October 1942): 420431; N. P. Banks to H. W. Halleck, December 17, 1863, in The War of the Rebellion, A Compilation of the Official Records of the Union and Confederate Armies (Washington, 1880-1902), Ser. I, Vol. XXVI, Pt. I, 457-459; "Battle Unit Details: United States Colored Troops: 76th Regiment, United States Colored Infantry," https://www.nps.gov/civilwar/search-battle-units-detail.htm?battleUnitCode=UUS0076RI00C; Joseph Glaathaar, Forged in Battle, 35-60. For scholarship on officer-enlistee relations, see the introduction.

${ }^{153}$ For a work stoppage against officer abuse, see Christopher Waldrep, Vicksburg's Long Shadow: The Civil War Legacy of Race and Remembrance (New York and Oxford: Rowman \& Littlefield Publishers, Inc., 2005), 60-66.

${ }^{154}$ Proceedings of a military commission convened at Fort Jackson, Louisiana, December 12-13, 1863, G-527 1863, Letters Received, Series 12, RG 94 (K-569), excerpted in Ira Berlin, et. al., The Black Military Experience, 442-449.
} 
The angry mutineers armed themselves, fired into the air, demanded the release of the drummers, and shouted obscenities. They called for the capture and killing of the lieutenant colonel if he did not comply with their demands, adding that they did not enlist to be whipped and that, "we want to be treated as soldiers." The officers gathered to quiet the men, ordering them to return to their quarters and disarm, and informing them that while Benedict had committed a wrong, their mutiny was unjustifiable. A group of men, especially Corporal Lewis Cady and Privates Jacob Kennedy, Charles Taylor, and Willis Curtis, all laborers when they enlisted, refused to obey the order, continuing to fire outside Fort Jackson at the half-hour mark. Curtis remarked that "This thing (officer abuse) has been going on long enough." The most aggressive participant in the revolt proved to be eighteen-year-old Private Abraham Victoria. A laborer born in Louisiana's St. James Parish, he proclaimed that "if none of the damned noncommissioned officers would take command, he would," and that if he captured Colonel Benedict, "I would eat his heart." While noncommissioned officers tended to enjoy prestige in the USCTs, soldiers like Victoria assumed such positions for themselves when they deemed their emancipation goals under siege. The macabre war cry against Benedict speaks to how black Union troops considered all obstacles to their human rights, whether of Confederate or Federal origin, to be targets of bloody retribution. Forming the companies and promises of justice enabled the officers to quell the mutiny within an hour. ${ }^{155}$

This incident resulted from preexisting tensions that developed between the men and Lt. Colonel Benedict while the regiment was stationed at Fort St. Phillip. There, he physically

\footnotetext{
155 Ibid.; Fred Harvey Harrington, “The Fort Jackson Mutiny,” Journal of Negro History 27, no. 4 (October 1942): 420-431; Service Records of Edward B. Smith, Frank Williams, Lewis Cady, Henry Green, Jacob Kennedy, Charles Taylor, Abraham Victoria, Abram Singleton, Volser Verrett, Willis Curtis, Julius Boudro, and James Hagan, "Compiled Military Service Records of Volunteer Union Soldiers Who Served the United States Colored Troops: 56th-138th USCT Infantry, 1864-1866," NARA, www.fold3.com.
} 
harmed them on a regular basis. When Benedict and a portion of the unit relocated to Fort Jackson, many asked in vain to remain stationed at St. Philip to avoid continuing to serve under Benedict. Instead, commanders failed to prevent the situation from festering.

Much of the documentation for Benedict's violent episodes resides in the report of a military commission. Captain William H. Knapp told the commission that he had observed the offending officer punch and kick men "because their brasses were not bright enough or their boots not polished." The commission learned about other harsh punishments: confinement in the guardhouse, carrying a ball and chain, tying up by the thumbs, and covering accused thieves in molasses all day. Adjutant General Lorenzo Thomas emphasized to the men who complained about Benedict's behavior that the Army had a policy of terminating the commissions of abusive officers. This assurance failed to match reality. With their superiors continuously ignoring or overlooking their plight, Benedict's last of countless abuses finally drove much of the regiment over the edge. General Thomas addressed the situation by reminding the officers of the proper treatment of their men and the penalties for violating this code of conduct. He then informed the enlisted men of the justice system to which they had access when they suffered mistreatment. The decision to mutiny, the general concluded, owed more to "an ignorance of their rights and the proper means of redress than to any pre-concerted plan of revolt." Commission investigators like General Nathaniel Banks saw "nothing to impair the confidence of the Government in the efficiency and reliability of black troops." Banks went further, arguing that the shortage of quality officers in the regiment directly caused the "outbreak" and "was such as could hardly be expected to produce any other result." While rare, the U.S. military's high command sometimes viewed mutiny as inevitable in certain undesirable conditions. ${ }^{156}$

\footnotetext{
${ }^{156}$ Proceedings of a military commission convened at Fort Jackson, Louisiana, December 12-13, 1863, G-527 1863, Letters Received, Series 12, RG 94 (K-569), excerpted in Ira Berlin, et. al., The Black Military Experience, 442-449;
} 
The Army's prosecutions in this case illustrated its official commitment to its duty to punish both officer cruelty and rank-and-file insubordination. It convicted Lt. Colonel Benedict of cruel and unusual punishment, dishonorably discharging him from service for acting like a violent plantation overseer. Twelve enlisted men—drummer Edward B. Smith; Corporals Lewis Cady and Henry Green; and Privates Frank Williams, Jacob Kennedy, Charles Taylor, Abraham Victoria, Abram Singleton, Volser Verrett, Willis Curtis, Julius Boudro, and James Hagan— faced charges of mutiny, while Private James H. Moore was tried for insubordinate conduct. The court found eight guilty. While two awaited execution, General Halleck commuted their punishment to imprisonment. Six convicted mutineers received sentences of hard labor from one to twenty years, while Moore endured hard labor under guard for one month. The guilty served their sentences at Fort Jefferson in Dry Tortugas, Florida. On February 27, 1865, while toiling in Florida, Private Taylor became involved in an altercation of an uncertain nature during which he resisted prison guards. The incident resulted in the guards shooting the prisoner, inflicting wounds from which he died on March 3 or 4 . While his service record lacks details, Taylor continued physically resisting perceived oppression while performing undesirable labor, an approach which cost him his life. All surviving convicts in the Fourth received remitted releases between February and April $1866 .{ }^{157}$ While the black Louisianans got a degree of justice against an exceptionally cruel white officer, the mutineers among them could not escape punishment.

Fred Harvey Harrington, “The Fort Jackson Mutiny,” Journal of Negro History 27, no. 4 (October 1942): 420-431; "Testimony before military commission," December 12, 1863, O.R., Series 1, Volume 26, Part 1, 459-473.

${ }^{157}$ Proceedings of a military commission convened at Fort Jackson, Louisiana, December 12-13, 1863, G-527 1863, Letters Received, Series 12, RG 94 (K-569), excerpted in Ira Berlin, et. al., The Black Military Experience, 442-449; Proceedings of GCM, Trials of Edward B. Smith, Private Frank Williams, Corporal Lewis Cady, Corporal Henry Green, Private Jacob Kennedy, Private Charles Taylor, Private Abraham Victoria, Private Abram Singleton, Private Volser Verrett, Private Willis Curtis, Private Julius Boudro, Private James Hagan, and Private James H. Moore, NN1301, RG 153, NARA; Service Records of Edward B. Smith, Frank Williams, Lewis Cady, Henry Green, Jacob Kennedy, Charles Taylor, Abraham Victoria, Abram Singleton, Volser Verrett, Willis Curtis, Julius Boudro, and James Hagan, "Compiled Military Service Records of Volunteer Union Soldiers Who Served the United States 
An epilogue to the Fourth Regiment, Corps d'Afrique's, mutiny, documented in a report, sheds light on the ability of at least one commander, Brigadier General William Dwight, to learn lessons from such incidents and to recognize the ties between black soldier mutinies and the African-American struggle for emancipation. In late January 1864, Colonel Charles Drew, who had ignored Benedict's whipping of the band members the previous month, went into custody for arbitrarily assaulting enlisted men of his own regiment for trivial offenses. The following month, Dwight explained his arrest of the colonel with the acknowledgment that the Fourth "will rise in revolt if the abuse of its soldiers is suffered to continue." In words that foreshadowed the violent USCT mutinies of the immediate postbellum months, Dwight warned that the next rebellion against officer cruelty "will not be bloodless." While Drew's victims appealed "to higher authority for protection against severe punishment," the general noted, not every soldier will do likewise. Drew's decision to kick and strike four troops constituted not discipline, but "physical terror, and when that goes beyond endurance, there follows - mutiny.” As long as officers like Drew and Benedict commanded those under Dwight, the latter felt that the post and garrison risked "worse scenes than those which followed" Benedict's whipping. Therefore, General Dwight recommended a prohibition on Drew leading the Fourth. ${ }^{158}$

More broadly, General Dwight desired to purge the Fourth Regiment of all its "rotten" components by disbanding it: discharging its officers and redistributing its men to other units. A root cause of these components was that the regiment's initial corps of officers consisted of proslavery men. As Dwight put it, when individuals of such sentiments command USCTs, too

Colored Troops: 56th-138th USCT Infantry, 1864-1866," NARA, www.fold3.com. The testimonies of the courts martial cannot be found.

${ }^{158}$ William Dwight to C. P. Stone, February 4, 1864, quoted in Fred Harvey Harrington, "The Fort Jackson Mutiny," Journal of Negro History 27, no. 4 (October 1942): 420-431. For earlier reports from Dwight that touched on similar issues, see William Dwight to Charles P. Stone, December 15, 1863, OR Series 1, Volume 26, Part 1, 860-861; William Dwight to Charles P. Stone, December 17, 1863, Ira Berlin, et. al., The Black Military Experience, 863-864. 
many blacks were "placed in their power for them to make good soldiers of," driving them to assume the status of "bad and brutal overseers" who mistook "tyranny...for discipline." Thus, a number of officers in Louisiana had begun their military careers under those who from the start opposed the Union's shift to emancipationist war aims. This notable aspect of the Fourth Regiment's career more directly connects the broader phenomenon of black soldier mutinies to the goal of nineteenth-century African Americans to not only destroy the institution of slavery but to rid U.S. society of its social, economic, and political remnants. ${ }^{159}$ For the post-abolition order to carry any substantial meaning, the former bondsman should never serve under those who once opposed his right to claim personhood and citizenship.

General Dwight continued to display a remarkable understanding for a white man of why some black troops decided to mutiny during the Civil War, but his most ambitious solutions to what caused the Fourth's mutiny ran into obstacles. USCT mutineers and comrades sympathetic with them would have agreed with his conclusion that the December 1863 Fort Jackson mutiny resulted not from an ingrained "spirit of mutiny," but from a desire for freedom and fair treatment. The late mutiny constituted an act of "resistance to oppression and violence from which they find no means of legitimate appeal and protection." However, Colonel Drew not only remained in the Army but also eventually commanded a black division by the summer of 1864 . Also, Major General Nathaniel P. Banks, commander of the Department of the Gulf, refused to implement Dwight's plan to disband the Fourth. Numerous other USCTs revolted in the very manner described by General Dwight, as did their Buffalo Soldier successors. ${ }^{160}$ While some commanders fully understood black soldier motivations and African-American visions of liberty, numerous others came short. The nineteenth-and early-twentieth-century U.S. Army never cured

\footnotetext{
${ }^{159}$ Ibid.

${ }^{160}$ Ibid; Keith P. Wilson, Campfires of Freedom, 206.
} 
itself of the toxic elements that violated the terms of emancipation and thereby caused black mutinies. Despite the conclusions of General Dwight, the Union Army kept enough aggrieved blacks ignorant of recourses, made these recourses difficult to pursue, and maintained enough white supremacist officers to ensure that camps remained fertile ground for black mutinies.

The experience of units like the Thirty-sixth USCI offer a case study in how the above instances of abuse followed by mutiny were avoidable. Reports from a black journalist named Thomas M. Chester repeatedly demonstrated the link between the likeliness of mutiny and officer treatment of the rank-and-file. He noted in August 14 that the Thirty-sixth was otherwise a "model regiment...distinguished by the undaunted bravery of the men and the gallantry of its officers." Also, during combat operations in mid-October 1864, commissioned officers praised the performance of the regiment's black sergeants in leading their companies. Two months later, when another officer, Lieutenant J. B. McMurdy, abused a black sergeant, Colonel Holman "sent (him) off...in disgrace to report to General Butler.” As Chester also noticed, under Holman's command, "no one in this division, so long as he commands it, will be permitted to abuse any man, whether he be white or black." In late October, their brigade commander dismissed one of their sutlers for price gouging. Furthermore, observers like Chester singled out the Thirty-sixth USCI as an example of how due to missionary schools constructed in regimental camps, former slaves by early 1865 had risen above "the depths of ignorance." The record shows that no further mutinous incidents erupted in this unit. When USCTs saw their superiors ruling in their best material interests and opening up opportunities for personal advancement, they could point to evidence that their emancipation process was moving ahead, forestalling armed resistance. ${ }^{161}$

\footnotetext{
${ }^{161}$ R. J. M. Blackett, Thomas Morris Chester, 97, 152-153, 168-169, 228. In the first example, Chester referenced a lieutenant dismissed for disobeying orders, being drunk on duty, conduct unbecoming an officer, and resisting arrest.
} 
The Civil War wave of African-American soldier mutinies proved to be merely the start of a decades-long story in which men of color revolted against perceived racism while serving in the U.S. Army. As with every other aspect of black life, soldiering in the postbellum period, from the immediate postwar months to Radical Reconstruction to Redemption and Jim Crow, presented new as well as old sets of challenges to the cause of black liberty. Though the Civil War killed slavery as an institution, it was only the latest stage in the long emancipation process. Just as black men no longer in chains during the war found remnants of bondage existing within a great manifestation of freedom-military service-African Americans in general found the promised land still a great distance away despite creating a new Union founded upon abolition in the summer and fall of 1865. As Christopher Hager describes emancipation, postbellum African Americans encountered "the close of a horrific era as well as the inception of a new odyssey of struggle." Recognizing this reality as early as November 1862, Frederick Douglass, regarding the building of black life after the arrival of freedom, proclaimed "Verily, the work does not end with the abolition of slavery but only begins." 162 This aspect of emancipation as a long, complicated process even after the Civil War became apparent among black Army personnel during the slow demobilization of the United States Colored Troops between mid-1865 and early 1867. While USCTs could claim victory over unequal pay, the physical abuse and infringements on bodily autonomy plaguing regiments did not just persist, but in some ways intensified, after the conflict.

\footnotetext{
162 Christopher Hager, Word by Word, 7 (first quote); “The Work of the Future," Douglass' Monthly, November,
} 1862, https://rbscp.lib.rochester.edu/4405 (second quote). 


\section{Chapter 3 \\ "All I want is to get out of the army, or, my rights": African-American Soldier Mutinies in the Immediate Postbellum Era}

On July 24, 1865, Private John Higgins of the Fifth U.S. Colored Heavy Artillery

(USCHA) resisted the labor and discipline of Army life since the end of the Civil War. After spending two grueling years performing garrison duty in Mississippi, the government's decision to keep his unit in the ranks after the fall of the Confederacy pushed Higgins over the edge. When ordered to fill a dozen comrades' canteens, the artilleryman claimed he was too tired to do so and used the occasion to condemn what he perceived to be racist practices in the Union Army. As he noted, "the colored soldiers are imposed upon," "trample[d] on," "kept cooped up like dogs," and continuously "kept under guard.” Meanwhile, his white comrades could move about freely. When an officer ordered Higgins bucked, the private threatened the life of anyone who intervened in his mutiny. Higgins also lambasted any black soldiers who "will stand by and see another tied up for nothing," referring to them all as "a set of damned cowards." Such cowardice invited white transgressions; if black soldiers sufficiently resisted, the mistreatment would cease. Directing greater anger to black collaborators, Higgins proclaimed that "any damned Negro that would assist a white man and punished a colored man was no soldier," as well as "God damn any Nigger that would help to tie another one, just to please the white men." He concluded his outburst by declaring that "the Negro had been run over long enough by white men, and it was time they defend themselves." The surrounding officers eventually placed Higgins into custody, tying him up by the wrists and bucking him. An August 1865 court-martial convicted him of mutiny, sentencing him to two years of hard labor at Fort Jefferson, Florida, and a loss of pay. ${ }^{163}$

\footnotetext{
${ }^{163}$ Proceedings of a General Court-martial in the case of Private John Higgins, Co. C, $5^{\text {th }}$ U.S. Colored Artillery (Heavy), General Court Martial Orders No. 12, Headquarters Department of Mississippi, November 11, 1865, filed with Maj. Gen. George H. Thomas to Adjutant General U.S.A., April 13, 1866, A-126 1866, Letters Received, ser. 360, Colored Troops Division, RG 94 (B-210), in Ira Berlin, Freedom: A Documentary History of Emancipation
} 
Seeking an early release, in late May 1866, Higgins wrote the Secretary of War. In the letter, Higgins emphasized the "very light" nature of his original offense and the "torture" he endured at the hands of his officers. With deferential language that contrasted with his previous bellicosity, he called the secretary "Honorable Sir," in whose "Kindness and well Known generosity" he trusted. Echoing other USCTs demanding a return to civilian life, the plea brought attention to Higgins' mother, wife, and four children, all of whom he was unable to support while incarcerated. He would not need to wait long. That June, the War Department released Higgins as part of an effort to free imprisoned soldiers whose units had mustered out. ${ }^{164}$

Along with this individual soldier's actions, hundreds of black men in other USCT units collectively revolted against the harsh circumstances of military service during the immediate postbellum period. The U.S. Army's personnel decisions sparked widespread resentment and an eruption of African-American mutinies lasting from the early summer of 1865 to the spring of 1866. These months present one of the most concentrated and widespread episodes of AfricanAmerican mutinous behavior. Amidst this rebellious storm, however, as Higgins' appeal and release revealed, USCTs also at times enjoyed leniency and sympathy from white allies.

The mutinous outbreak in the year following the cessation of hostilities sheds additional light on why any serviceman would risk his life or livelihood in choosing to mutiny and why mutinies occurred more frequently in certain periods. As seen previously, during the Civil War,

1861-1867: Series II: The Black Military Experience (Cambridge, Cambridge University Press, 1982), 475-476. A farmer born in Fayette, Kentucky, John Higgins enlisted in what became the Fifth USCHA on August 1, 1863, in Natchez, Mississippi, for a three-year term, at the age of twenty-six. Given his Kentucky birth, either his master sold him to Mississippi before the war or he remained in the Bluegrass State and fled southward to join the Union Army. Over the course of the war, for reasons not specified in his service record, Higgins received promotions and demotions, becoming a sergeant and a corporal at different times before returning to the rank of private in April 1865. See John Higgins Service Record, NARA, www.fold3.com.

${ }^{164}$ Ibid.; John Higgins to Hon. E. M. Stanton, May 28, 1866, H-174 1866, Letters Received, ser. 360, Colored Troops Division, RG 94 (B-253), in Ibid, 474-476; Linda Barnickel. Milliken's Bend: A Civil War Battle in History and Memory (Baton Rouge: Louisiana State University Press, 2013), 183. 
black troops were more likely to mutiny during the height of the unequal pay controversy and/or if they endured neglect or abuses from their superiors. Since the early postwar months brought even more intolerable abuse to USCTs, the rates of mutiny expanded likewise across the U.S. Army's "Sable Arm." Forced to remain in the service despite Union victory, these black troops believed that their family's livelihood, their manhood, and their autonomy as U.S. citizens were again under grave threat. As the war-ravaged nation began to demobilize and rebuild, these disgruntled troops rose up, threatening to overwhelm the U.S. Army.

As this chapter reveals, the USCT mutinies in the year following the Civil War's end form another part of the larger narrative illustrating how nineteenth-century African Americans revolted against whites holding positions of authority over them in order to gain bodily autonomy and enjoy improvements in their material well-being, the goals of the long emancipation. The numerous wartime mutinies helped shape the African-American struggle for freedom as slavery was collapsing and as the seeds of a biracial democracy were being planted. Thus, these rebellions immediately following the conflict constituted the next stage of the emancipation process. Though the military justice system largely defeated their efforts, these dissident acts tried to aid African Americans with shaping the terms of their new freedom after they had broken the chains of bondage. Given these direct connections to the long emancipation, certain USCT mutinies of the immediate postbellum period allow us to examine what black men envisioned for their post-slavery lives and what challenges they faced in doing so. Such contradictions between expectation and reality depended on various contexts: the particular unit, location, and point in time. The mutinies among black Civil War veterans who had yet to muster out connect with the broader cultural, political, social, and historiographical themes of the era. 
A quantitative comparison of sentencing from twenty-one wartime and eighteen immediate postbellum mutinies involving the USCTs highlights the reduced tolerance that white commanders had for ill-disciplined African Americans in the months following the Confederacy's collapse. Ten of the wartime mutinies (nearly half) resulted in hard labor sentences, while twelve postwar black mutinies (exactly two-thirds) did so. Discounting commutations and rulings without a specified length of imprisonment, the average hard labor sentence for mutiny given to black Union troops during the Civil War equated to 13.1 months; the average hard labor sentence for a black veteran still in uniform more than doubled to 30.01 months. On the other hand, convicted black mutineers were more likely to be sentenced to imprisonment and drudgery for the rest of their terms of service during vs. after the war. Courtsmartial ruled that twenty-four of fifty-five African Americans (44\%) convicted of mutiny between 1863 and spring 1865, eighteen of whom did so together in a single episode, would toil for the remainder of their terms. Officials later told thirteen of seventy-seven (17\%) that they would perform hard labor until mustered out if found guilty from the summer of 1865 to 1866 . While the Army put only three participants in a total of two episodes to death during hostilities, it subsequently executed eight in two of the conquered South's own episodes. Complementing the greater sense of urgency to which mutineers attributed their situation beginning in early summer 1865 was an increased risk to their livelihoods and lives if they chose to disrupt operations and subvert authority as a desperate means of effecting positive change or expressing frustration. ${ }^{165}$

\footnotetext{
${ }^{165}$ Data based on spreadsheet in author's files. The wartime units cited were the Third South Carolina Infantry, Fifty-fourth Massachusetts Infantry, Fifty-fifth Massachusetts Infantry, Thirteenth USCI, Forty-ninth USCI, Fourteenth Rhode Island USCHA, Twenty-fifth USCI, Thirty-second USCI, Thirty-sixth USCI, Thirty-third USCI, Fifty-seventh USCI, Seventy-sixth USCI, Eighty-first USCI, Eighty-fourth USCI, and 113th USCI. The mutinous USCTs representing the postbellum period in the dataset consist of the First USCC, Second USCC, Third USCI, Fifth USCHA, Seventh USCI, Twelfth USCHA, Twenty-ninth Connecticut Infantry, Thirty-first USCI, Thirtyseventh USCI, Thirty-eighth USCI, Forty-first USCI, Forty-third USCI, Forty-fourth USCI, 103rd USCI, 109th USCI, 116th USCI, 117th USCI, and 127th USCI.
} 
Despite the reality that early postbellum mutineers were much more likely to receive longer hard labor sentences and die at the hands of a firing squad than if they had rose up earlier in their careers, African-American Union soldiers never stopped enjoying unprecedented due process rights. First, no soldier suffering at Dry Tortugas or another federal prison stayed longer than two years; when the prisoner's unit mustered out of existence, he was finally granted his desired release into civilian life. By 1867, every Civil War volunteer regiment, including the USCTs, had retired. Also, while only two USCTs (3.6\%) charged with mutinous conduct during the war were acquitted, fourteen accused postbellum mutineers (18.2\%) experienced the relief of hearing their name cleared. Further, strength in numbers, which helped USCTs avoid prosecution altogether during the Civil War, maintained its utility in the early postbellum U.S. Army. Mass mutinies, those consuming anywhere from an entire company to a full regiment, still tended to shield perpetrators from legal trouble. Of the five wartime mass USCT mutinies, only one sergeant of a single episode was prosecuted; a second event witnessed officers free suspects from custody; and a third saw the mutineers suffer from corporal punishment but then released. Among the early postwar Sable Arm, the record indicates that no African-American enlistee faced legal consequences in either of the period's two mass mutinies. When the entire Fiftyseventh USCI (wartime) and the $117^{\text {th }}$ USCI (postbellum) rose up, Army authorities decided to only punish their white ringleaders, dismissing them from the service in both cases. ${ }^{166}$

The prosecution or lack thereof of mass USCT mutinies suggests that the high command was most concerned with setting an example. If only a small portion of a unit rebelled, officers prosecuted and convicted as many offenders as the evidence allowed, advising the non-mutinous majority to remain disciplined or else. Yet, when overwhelmed with the insurrection of an entire

${ }^{166}$ Ibid. 
unit, officers expressed a willingness to discourage further acts by telling prospective ringleaders that they were far more likely to suffer consequences. Once the presiding officer listened to testimony and deliberated, however, they acquitted those for whom insufficient evidence existed to tie them to a recent mutiny. African-American soldiers shared justifiable concerns about the tenuous nature of their freedom if they were among the unfortunate group ordered to perform the least glorious duties seen in the USCTs' entire career. Yet, the legal decisions that spared dozens of would-be convicts of degrading punishment or the maximum penalty would have reassured them that their long emancipation process had not regressed as much as they feared.

As the above data indicates, after all they had struggled for and achieved during the war, African Americans, now part of a new Union that forbid slavery and welcomed then as citizens, were still willing to struggle to implement their vision of emancipation. In the year following the end of the war, the actions and words of non-mutineers provide insights into African-American soldiers' expectations and grievances, sentiments which drove others to mutiny. Perceived violations of the rights of a formerly enslaved black man to care for his family as a household head and to protect his person from despots constitute one such gap between expectations and reality. Confederate defeat and the destruction of slavery, in USCT eyes, had secured such rights. With the war finished and slavery gone, a goal of emancipation was, as one formerly enslaved sergeant put it, a life where, "no man can say to me come and go, and I be forced to obey." 167 The strict hierarchy of the military, based on the rank-and-file obeying their superiors without question, constituted a temporary relationship. However, this relationship lasted a year longer than black troops had hoped. Since white units had enlisted earlier in the war, they

\footnotetext{
${ }^{167}$ Elijah P. Marrs, Life and History of the Rev. Elijah P. Marrs, First Pastor of Beargrass Baptist Church, and Author (Louisville, Ky: The Bradley \& Gilbert Company, 1885), 25. Marrs felt uncomfortable continuing to receive orders from white men with which he needed to comply. He coped by reminding himself "that I was a soldier fighting for my freedom, and this thought filled my heart with joy." See Ibid.
} 
disproportionately received discharges as victorious U.S. forces demobilized. As a result, African-American troops moved from eleven percent of the Army at war's end to thirty-six percent by fall $1865 .{ }^{168}$ Since the slaveholding aristocracy laid in ruins, there was no legitimate reason to continue to delay the realization of black soldiers' envisioned freedom.

The masculine devotion to one's family remained paramount as USCTs entered the postbellum era. In May 1866, a member of the $116^{\text {th }}$ U.S. Colored Infantry (USCI) related an account of suffering families in a petition to the president signed by six comrades. To justify relief for their families to his white audience, the petition emphasized his comrades' patriotism and discipline. In contrast to mutineers, the writer agreed that soldiers have a duty to follow all orders. He and his comrades enlisted in "this great and Noble coas" without hesitation and afterward "came out like Men." They proved obedient and orderly while performing picket and garrison duty, and had only recently dreaded their service. They documented how "we Poore Nation of a Colered rast [race]" left their homes and families to serve in the Army so that they could ultimately improve their condition and become self-sufficient. Despite these goals and sacrifices, freedpeople lacked money and property, a material condition that closely resembled that of slavery. The petitioners had various questions. What options did they have when "the Poore old Soldier had nothing to leave" himself or his family? After spending the prime of their lives in slavery, was it the destiny of freedpeople to "lye out of Doors Like Beast or sum brute"? To this, "I says No." The root of the problem, they claimed, was that their officers illegally compelled enlisted men to work as servants or cooks and inflicted severe punishment without due process. These soldiers' fears match those of some black civilians. Looking ahead to a bleak future, in May 1865, the newly freed slaves of James Greenlee remarked that "it was poor

\footnotetext{
${ }^{168}$ Ira Berlin, The Black Military Experience, 733.
} 
freedom to starve" and have "nothing to live on or to work on." 169 As during the wartime period, a number of USCTs hoped that non-mutinous collective action, such as petitioning the government, would advance a vision of freedom that spared them of material insecurity.

These same grievances motivated other USCTs to mutiny. Unlike petitioners, mutineers considered all legal, peaceful avenues of redress exhausted. Petitioners hoped that greater publicity of Army injustices would usher in a resolution while mutineers, having reached the end of their rope, felt that they had nothing left to lose. Though most USCTs never mutinied, the mutineers and the disciplined alike shared the same gap between hopes and reality. Mutiny represented the most extreme reaction against despised conditions. Many USCTs had endured southern slavery or northern racism, performed their duty well in order to create a better life for themselves and their families, and yet they faced a future of destitution and second-class citizenship. For some, such a legacy of their service was too appalling to accept peacefully. In the months following the Civil War's end, many African-American soldiers did not mutiny, but decided that the solution to their desire to return to civilian life was to simply leave. The Fourteenth USCHA saw their unit's desertion numbers jump to thirty men between May and July 1865. Since they occupied their own state, these North Carolinian artillerymen could more

\footnotetext{
${ }^{169}$ Capt. G. E. Stanford, et. al., to Mr. President and the Ceterry of War, May 30, 1866, P-163 1866, Letters Received, ser. 360, Colored Troops Division, RG 94 [B-272], in Ibid., 779-781 (first four quotes); James Greenly Diary, May 9, 1865, Southern Historical Collection, Wilson Library, University of North Carolina at Chapel Hill (fifth quote). For examples of other petitions by black troops expressing concerns for family welfare, see Richard Etheredge and Wm. Benson to Genl. Howard, May or June 1865, Unregistered Letters Received, ser. 2453, NC Asst. Comr., RG 105 [A-648], in Ibid., 729-730; Privt. Calvin Holly to Major General O. O. Howard, December 16, 1865, H-72 1865, Registered Letters Received, ser. 2052, MS Asst. Comr., RG 105 [A-9050], in John David Smith, We Ask Only For Even-handed Justice: Black Voices from Reconstruction, 1865-1877 (Amherst and Boston: University of Massachusetts Press, 2014), 35-36.
} 
easily head home than one stationed in another state or region. Rather than confront their officers and demand a formal discharge from them, these artillerymen bypassed the Army altogether. ${ }^{170}$

A controversial personnel relocation order proved crucial in pushing those resentful of remaining in the Army after war's end to revolt. General-in-Chief Ulysses S. Grant commanded Major General Phil Sheridan to send a force to the Southwest border. Its mission was to enforce the Monroe Doctrine against the French imperial forces that invaded Mexico in 1861. Preoccupation with crushing the rebellion prevented the federal government from acting on this foreign policy issue earlier. To fulfill Grant's order, Major General Henry Halleck sent his allblack Twenty-fifth Corps to Texas. He identified a "want of discipline" in the corps that "renders it a very improper force for the preservation of order in" Federal-occupied Virginia, as well as their poor "influence on the colored population." The role of U.S. troops in the Lone Star State was to present a show of force to, and potentially go to war with, the French regime, all while removing USCTs from Virginia's newly-freed black and ex-Rebel population centers. ${ }^{171}$

A major issue for the troops about to undertake this journey was how it would separate them from their struggling families in nearby contraband camps, exacerbating an already desperate situation. On the date they set sail from Norfolk to Texas, June 10, 1865, an order cutting off rations for soldiers' wives and children went into effect. According to the capitalist philosophy inspiring Federal contraband policy, state aid stifled individual initiative. White northern officials contended that wage parity meant that black troops could now support their families themselves. This logic ignored the severity of ex-slave poverty and the inability of black

\footnotetext{
${ }^{170}$ Richard M. Reid, Freedom for Themselves: North Carolina's Black Soldiers in the Civil War Era (Chapel Hill: University of North Carolina Press, 2008), 258. Suspecting that the deserters lived around New Bern and Goldsboro, Lieutenant Colonel Poor sent a party to search for them. The operation proved unsuccessful.

${ }^{171}$ Joseph Glatthaar, Forged in Battle, 218; Richard Reid, Freedom for Themselves, 266; H. W. Halleck to U. S. Grant, April 29, 1865, in United States War Department ed., Official Records of the War of the Rebellion, Series 1, Vol. 46, Part 3, Section 2, 1005-1006 (quotes). The army also sent soldiers from western-based white units to occupy Texas.
} 
soldiers to support family members from a thousand-mile distance and with delayed payments. While the attainment of equal pay promoted black freedom, the continuation of insufficient pay attested to how much more ground remained in the pursuit of economic independence. ${ }^{172}$

Frightening rumors of re-enslavement also motivated units of the Twenty-fifth Corps to revolt against the upcoming Texas expedition. Not only did the prospect risk nullifying the Union's victory, but it would also have separated the men from their families to a degree comparable to the devastating results of antebellum slave sales. A commissary sergeant reported that "there was quite an excitement" among members of the Twenty-ninth Connecticut Colored Infantry after hearing their officers planned to sell them into Latin-American bondage during the voyage. The First and Second U.S. Colored Cavalry (USCC) believed that the underlying purpose for the move was their forced employment as white soldiers' servants for five-year terms. Another rumor held that the troops would toil on cotton plantations to pay off the national debt. While these stories proved inaccurate, the USCTs' overall discontent with postbellum military service and the poor planning and communication on the part of their officers made the situation ripe for rumor and unrest. A First USCC lieutenant reported that despite numerous men receiving assurance from officers that the rumors were incorrect, "a marked change came over them, and they became sullen and disobedient." Whatever benefit refutation of the rumors brought, it did nothing to lessen the anger resulting from the confirmation of the order cutting rations and the realization that they still needed to wait longer to return to civilian life. ${ }^{173}$

\footnotetext{
${ }^{172}$ Genl. Geo. H. Gordon to Capt. O. Brown, June 6, 1865, vol. 88/174 VaNc, pp. 168-169, Letters Sent, ser. 1622, Dist. Of Eastern VA, RG 393 Pt. 2 No. 72 [C-3129], in Ira Berlin, The Black Military Experience, 722-723; Joseph Glatthaar, Forged in Battle, 219.

${ }^{173}$ Joseph Glatthaar, Forged in Battle, 219; Frederick W. Browne, "My Service in the U.S. Colored Cavalry," 1908, http://www.archive.org/stream/myserviceinuscol00brow/myserviceinuscol00brow djvu.txt; A. H. Newton, Out of the briars : an autobiography and sketch of the Twenty-ninth regiment, Connecticut volunteers (Philadelphia: The A.M.E. Book Concern, 1910), 70, Philadelphia Inquirer, 6/13/65, "The Mutiny at Fortress Monroe," The Philadelphia Inquirer, 06-16-1865, “American Civil War Newspapers, 1840-1877," Redex, https://infowebnewsbank-com.www.libproxy.wvu.edu/; "The Colored Troop Mutiny," Daily Constitutional Union, 06-19-1865,
} 
In the minds of mutineers and non-mutineers who shared their sentiments, the Virginiato-Texas voyage itself constituted a potentially grave setback to the continued process of their emancipation. As one white officer noted in his account of the below mutiny, during the domestic slave trade, Texas represented, "a sort of hell to which they would be sold if they misbehaved." ${ }^{174}$ Memories of the domestic slave trade must have crossed these former bondsmen's minds. One also wonders whether the voyage to Texas also reminded the men of the colonial Middle Passage, the first and worst forced voyage blacks endured at white hands. Further, the rumors hit a sore spot, calling into question the permanence of soldiers' newfound freedom. These soldiers' reaction represents their determination to resist any partial return to coerced labor, no matter how fantastical the rumors may appear to be in hindsight. Their nonlinear, incomplete path from slavery to freedom also made them suspicious of white plans. ${ }^{175}$

Among those in the Twenty-fifth Corps who mutinied in response to the order to ship out to Texas were members of the First USCC, a regiment recruited from Virginia's formerly enslaved population. Organized at Camp Hilton, Virginia, in late December 1863, the unit began its career occupying Fort Monroe and Williamsburg. The First fought with Benjamin Butler's Army of the James south of the James River in the weeks leading up to the Petersburg Campaign in May 1864. After participating in the Petersburg siege, the regiment moved back to

Ibid.; "Norfolk. The Mutiny among Colored Troops. How it Originated! The Negroes Told They Were To," The Philadelphia Inquirer, 06-19-1865, Ibid. For a mutiny within the Twenty-ninth Colored Connecticut, see Proceedings of a GCM, Trial of Robert Cuffey, MM-3067, RG 153, NARA.

${ }^{174}$ Personal Narratives of Events in the War of the Rebellion: Being Papers Read before the Rhode Island Soldiers and Sailors Historical Society, Sixth Series, Nos, 1-10 1903-1905, page 38.

${ }^{175}$ While the most notable of their type, the mutinies of the Twenty-fifth Corps against the forced relocation from Virginia to Texas were not the only ones to have such a motivation. In May 1866, two companies in the Arkansasbased Fifty-seventh USCT briefly mutinied against orders to join the Third U.S. Cavalry on an expedition to New Mexico. They "loaded their guns," but "when the test came...they obeyed orders...to stack their arms." Their officers quelled the mutiny. See Robert Patrick Bender, "Fifty-seventh Regiment, United States Colored Troops (US)," http://www.encyclopediaofarkansas.net/encyclopedia/entry-detail.aspx?search=1\&entryID=6256; "Mutiny among the Colored Troops," The Macon Daily Telegraph, 06-21-1866, "American Civil War Newspapers, 18401877," Redex, https://infoweb-newsbank-com.www.libproxy.wvu.edu/. 
Portsmouth's eastern Virginia defenses in August, where it remained until war's end. In preparation for the Texas expedition, the Army sent the command to City Point. ${ }^{176}$

The regiment's mutiny played out gradually. As press coverage put it, "for some time a mutinous spirit has existed in the colored cavalry brigade belonging to the" corps. Not just members of the First, but also of the Second and Fifth USCC, declared that they, "would not be sent to Texas" and "that the government had no right to send them there." Initially, officers across the corps considered rumors that their men would rise up "as the grumblings peculiar to the African race." When Colonel James Shaw of the Seventh USCI visited his men's camp one evening, he heard them thank the Almighty for protecting them, "on their voyage on the mighty deep." Shaw believed "that kind of men don't mutiny." In the case of the Seventh USCI, the soldiers boarded the ship and sailed to Texas without incident. ${ }^{177}$

While certain regiments avoided the crisis, the reports that other units in the Twenty-fifth Corps would revolt proved accurate. The mood of discontent finally worsened to the point of open mutiny when the troop transports arrived at a Fortress Monroe wharf on June 12, 1865. The First USCC's troops felt especially aggrieved by their inability to materially support their families if they departed, compounded by a six-month delay in payments to the soldiers.

While making their way down the James River from City Point, aboard the steamer Whildin, the cavalrymen began by firing their newly-issued carbines at the shore. Lieutenant Frederick W. Browne, who tried halting this, recollected that as he drew his revolver and approached the men in the lower deck, "a dozen carbines were put to my head and breast, and I

\footnotetext{
${ }^{176}$ Civil War Service Records of the First United States Colored Cavalry, NARA, www.fold3.com.

177 "The Colored Cavalry at Fortress Monroe," Philadelphia Inquirer, June 16, 1865 (first, second, and third quotes); James Shaw, "Our Last Campaign and Subsequent Service in Texas," in Personal Narratives of Events in the War of the Rebellion: Being Papers Read before the Rhode Island Soldiers and Sailors Historical Society, Sixth Series, Nos, 1-10 1903-1905, page 38-39 (third through seventh quotes).
} 
was told that I could kill one man, but it would be the last one I ever would kill." Once the troops arrived at Hampton Roads, they refused to board the transport Meteor. Officers persuaded three of the four companies aboard. The fourth company proved incalcitrant, staying on the Whildin. The companies aboard the Meteor then began acting unruly. Soldiers threatened to shoot those officers who implemented the Texas expedition. The most ambitious proposed taking the officers into custody and seizing control of the ship themselves. Concluding their men to be at "the height of mutiny," Meteor officers directed the ship to a wharf near Fortress Monroe. White Pennsylvanian troops arrived under orders to quell the most mutinous company, pointing artillery guns at its members. The Pennsylvanians' commander, Major Von Schilling, sent the Whildin to the wharf, where a number from his unit boarded with loaded muskets and drawn bayonets. The next part of Schilling's plan involved removing the mutineers from the boat two or three at a time in a single-file line. When an officer reminded the mutineers that as soldiers, they needed to obey orders, the Whildin group reluctantly agreed to disarm. The officers put the prisoners under guard before taking them back aboard and placing the ringleaders in irons. ${ }^{178}$

Black civilians from Hampton and Slabtown flooded to the wharf to observe the event. Most spectators were black women who sympathized with the soldiers and who as a newspaper account put it, "glanced deprecating looks at the piles of carbines and sabers." The visitors also fed the hungry mutineers with pies and cakes. These actions suggest that civilian freedpeople

\footnotetext{
178 “Reported Mutiny Among Colored Troops,” Albany Journal, 06-15-1865“American Civil War Newspapers, 1840-1877," Redex, https://infoweb-newsbank-com.www.libproxy.wvu.edu/; "Mutiny among Negro Troops,” The Daily Ohio Statesman, 06-16-1865, Ibid.; Philadelphia Inquirer, 6/13/65, Ibid.; "The Mutiny at Fortress Monroe," The Philadelphia Inquirer, 06-16-1865, Ibid.; "The Colored Troop Mutiny," Daily Constitutional Union, 06-191865, Ibid.; "Norfolk. The Mutiny among Colored Troops. How it Originated! The Negroes Told They Were To," The Philadelphia Inquirer, 06-19-1865, Ibid.; "The Colored Gentlemen on the Rampage--The African Elephant Becoming Troublesome--Mutiny Among Negro Troops at Fortress," Crisis, 06-21-1865, Ibid.; "Mutiny among the Colored Troops at Fortress Monroe," Weekly Patriot And Union, 06-22-1865, Ibid.; "Another Mutiny among the Negro Troops," Weekly Patriot And Union, 06-22-1865, Ibid.; "Mutiny of Negro Troops," The Daily Ohio Statesman, 06-23-1865, Ibid.; "Mutiny among the Colored Troops," The Macon Daily Telegraph, 06-24-1865, Ibid.
} 
recognized that mutinies like that of the First USCC formed part of the broader struggle to advance the livelihood of the entire African-American community. ${ }^{179}$

Schilling directed his men to place those black soldiers still aboard the Meteor on land before disarming them in a similar process. Some Meteor mutineers mistakenly thought that their superiors took them ashore due to a cancelling of the Texas expedition. According to Lieutenant Browne's 1908 account, once brought back aboard, the Meteor group resumed their riotous behavior after realizing that the voyage to Texas would still happen. One mutineer, Browne contended, climbed on the pilot house near the bow and shook his fist at the officers on the quarterdeck while declaring, to a cheering audience: "You damned white livered — of —— we will throw you overboard." The proclamation prompted three officers, armed with their revolvers, to plow through the crowd, jerk the orator off the pilot house and drag him to the quarterdeck. When the orator repeatedly resisted corporal punishment, Captain Whiteman shot him, mortally wounding him. The mutineers charged at the officers with axes and lumber, halting when they noticed their targets preparing to fire. Afterward, authorities disarmed the rest of the black cavalry brigade as it arrived from another ship. Schilling's white artillerymen, along with the fort's guns and water surrounding the newly arrived black cavalrymen, served to discourage further mutinous behavior during the disarming process. As they surrendered, observers noted pained expressions on their faces. A general reporting on the mutiny praised the officers for promptly restoring order. Virginia's Freedmen's Bureau blamed the mutiny on the

\footnotetext{
179 "Reported Mutiny Among the Colored Troops--The Cavalry Refuse to go South--They Quietly Submit to Being Disarmed," New York Times, June 16, 1865, https://www.nytimes.com/1865/06/16/archives/reported-mutinyamong-the-colored-troopsthe-cavalry-refuse-to-go.html.
} 
government's failure to adequately provide for the finances of black soldiers and their

families. $^{180}$

Remarkably, the mutineers of the First USCC, unlike others in the immediate postbellum months, suffered few consequences for their offenses. The record contains no court-martial of anyone for conducting the mutiny. It ultimately managed to only delay, not block, the voyage to Texas. The regiment served along the Rio Grande until it mustered out in February 1866. ${ }^{181}$ In December 1865, anonymous members of the First USCC wrote to an unidentified Washington official giving their side of the story regarding the mutiny of the previous summer. They deemed the government's decision to suspend aid for their families as equal to punishment for treason. The soldiers described how they had endured fatigue duty since July without a furlough, all while their families wrote them desperately describing their misery. The writers sought to know the reasons for this "dishonorble in treatment." They expected to be mustered out

${ }^{180}$ Brevet Brig. General Geo. W. Cole to [25 ${ }^{\text {th }}$ Army Corps Headquarters], June 1865, Miscellaneous Letters, Orders, Reports \& Circular Letters Received, ser. 518, $25^{\text {th }}$ Army Corps, RG 393 Pt. 2 No. 9 [C-4507], in Ira Berlin, The Black Military Experience, 723-725; James Shaw, "Our Last Campaign and Subsequent Service in Texas," in Personal Narratives of Events in the War of the Rebellion: Being Papers Read before the Rhode Island Soldiers and Sailors Historical Society, Sixth Series, Nos, 1-10 1903-1905, page 39; Frederick W. Browne, "My Service in the U.S. Colored Cavalry: A Paper Read Before the Ohio Commandery of the Loyal Legion, March 4, 1908," http://www.archive.org/stream/myserviceinuscol00brow/myserviceinuscol00brow_djvu.txt; "Reported Mutiny Among Colored Troops," Albany Journal, 06-15-1865, “American Civil War Newspapers, 1840-1877," Redex, https://infoweb-newsbank-com.www.libproxy.wvu.edu/; "Mutiny among Negro Troops," The Daily Ohio Statesman, 06-16-1865, Ibid.; Philadelphia Inquirer, 6/13/65, Ibid.; "The Mutiny at Fortress Monroe," The Philadelphia Inquirer, 06-16-1865, Ibid.; "The Colored Troop Mutiny," Daily Constitutional Union, 06-19-1865, Ibid.; "Norfolk. The Mutiny among Colored Troops. How it Originated! The Negroes Told They Were To Be Servants of White Troops," The Philadelphia Inquirer, 06-19-1865, Ibid.; "The Colored Gentlemen on the Rampage--The African Elephant Becoming Troublesome--Mutiny Among Negro Troops at Fortress," Crisis, 06-211865, Ibid.; "Mutiny among the Colored Troops at Fortress Monroe," Weekly Patriot And Union, 06-22-1865, Ibid.; "Another Mutiny among the Negro Troops," Weekly Patriot And Union, 06-22-1865, Ibid.; "Mutiny of Negro Troops," The Daily Ohio Statesman, 06-23-1865, Ibid.; "Mutiny among the Colored Troops," The Macon Daily Telegraph, 06-24-1865, Ibid.

${ }^{181}$ Civil War Service Records of the First United States Colored Cavalry, NARA, www.fold3.com. The only member of the black cavalry brigade to be tried for resisting the Texas expedition was an individual mutineer in the Second USCC. While his transport sailed down the James River, Private John Blakely confronted his officer. Convicted on a "mutiny" charge, Blakely was imprisoned at Brazos Santiago until his regiment mustered out in February 1866, at which point he was dishonorably discharged. See John Buckley Service Record, NARA, www.fold3.com. 
of the Army by this point in time, which "any good hearted man" would support. They enlisted as U.S. soldiers, before finding themselves treated once again as slaves. The wives of Confederates, they contended, received more care and protection than black soldiers' spouses. Desperate to protect their needy families, the petitioners offered to pay the War Department for one year of service in exchange for a discharge. The soldiers asked to be rewarded for, "what wee have done right" during their service just as they have been punished, "for any thing that wee do" wrong. ${ }^{182}$ The mutineers witnessed the confirmation of fears about what would become of their families if they lost support from the household head.

The great concern the First USCC's mutineers had for their families' welfare can be traced to their state's experiences with bondage and abolition. As residents of an Upper South state involved in the domestic slave trade, their masters might have sold family members to the Deep South in the 1850s. Those who enlisted in the regiment lived under regulations of enslaved and free black behavior passed in the early nineteenth century in response to Gabriel's and Nat Turner's slave insurrections. They also resided in the state targeted by John Brown's Raid, after which paranoid whites formed militias in preparation for another northern abolitionist invasion.

Martin Delany, an African-American writer born in the Old Dominion, lionized overt black resistance in his 1858-1861 work Blake. In the book, the main character emphasized "stand[ing] still and see[ing] the salvation," defined as the act of clandestinely plotting an insurrection and implementing the plan once someone gave a signal to do so. The First USCC's mutiny followed an African-American tradition of occasionally engaging in full-scale revolt, as modeled in Blake, to free and improve the lives of themselves and their families. For the mutineers, the government's recent actions - cutting off rations, delaying payments for months,

\footnotetext{
182 Unsigned to Sir, December 1865, A-8 1866, Letters Received, ser. 360, Colored Troops Division, RG 94 [B203], in Ira Berlin, The Black Military Experience, 725-727.
} 
and compelling them to move across the country-represented the latest example of white abuse and control dating back to slavery's heyday. These injustices mandated an uprising. ${ }^{183}$

When white Virginians brought the state into the Confederacy and began resisting Union invasion, enslaved and free black Virginians took the first steps toward full emancipation. They first fled plantations or C.S. fortifications for U.S. lines. The eastern black-majority tobacco belt counties, drained of white men as residents hurried to enlist, feared servile revolt. Justifying these worries, the tide of runaway slaves grew accordingly as the Union Army penetrated deeper into the Old Dominion and shifted to a hard war policy. As they gradually toppled the antebellum social order, black Virginians located lost family members, reestablishing kin networks disrupted by slavery. To bring down the slaveholders' republic and earn money for their families, black Virginian men enlisted and participated proudly in the Petersburg and Appomattox campaigns. The U.S. Army presence and its employment opportunities offered black families a double-edged sword: legal emancipation, official spousal unions, rations, and wages on one hand; and impressment, unsanitary camps, and physical injury or death from abuse or combat on the other. The hardships soldiers' wives and children faced at federal camps meant that the familial separation resulting from the Texas expedition was the latest in a long line of threats to the livelihoods of USCTs' loved ones. As historian Michelle A. Krowl has noted, the military emancipation seen in Virginia gave black men an unprecedented opportunity to assume the role of family protector, which slavery had denied them. It was this role the mutineers of the First USCC assumed while on the James River in mid-June 1865. ${ }^{184}$

\footnotetext{
${ }^{183}$ William Blair, Virginia's Private War: Feeding Body and Soul in the Confederacy, 1861-1865 (New York and Oxford: Oxford University Press, 1998), 13, 15, 24, 29-30; Martin R. Delany, Blake; or, The Huts of America, 18591862, Floyd J. Miller, ed., (Boston: Beacon Press, 1970).

${ }^{184}$ William Blair, Virginia's Private War, 41, 46-47, 78, 122-123; Michelle A. Krowl, "For Better or For Worse," in Catherine Clinton, eds. Southern Families at War: Loyalty and Conflict in the Civil War South (Oxford: Oxford University Press, 2000), 35-48; A. Wilson Greene, The Final Battles of the Petersburg Campaign: Breaking the Backbone of the Rebellion (Knoxville: University of Tennessee Press, 2008).
} 
Having advanced the cause of black freedom through their wartime flight and military service, black mutineers in the First USCC felt they needed to continue the struggle to promote family welfare as they entered post-emancipation life. Following their eventual return to civilian life, black veterans looked to the Freedmen's Bureau and their own initiative to secure the most fruitful labor arrangements. Thus, this type of mutiny occurring after the war but before African Americans mustered out of the Union Army served as the final act of resistance in the transitionary stage between slavery and freedom. ${ }^{185}$

As they would in other time periods, newspapers captured the American public's views of immediate postbellum black mutinies like that of the First USCC. Beyond publishing accounts of the events, the press shed light on white debates and anxieties over black citizenship and the process of emancipation. ${ }^{186}$ As the Philadelphia Inquirer put it, since the black cavalrymen who mutinied against the order to sail to Texas, "have all along behaved so admirably, even under the most trying and disadvantageous circumstances," this conduct took, "everybody by surprise." The correspondent then noted that such an event makes blacks and their white allies regretful because this happened just as the push for black suffrage in the South was gaining steam. A New York Times article decried the acute poverty into which the government had allowed USCTs and their families to descend. As it emphasized, "Everyone at all familiar with the army, knows that nothing so tends to breed discontent and mutiny as the withholding of the soldier's pay." 187

\footnotetext{
${ }^{185}$ William Blair, Virginia's Private War, 137, 140. For a study of freedpeople's efforts to reunite with long-lost family members after the war, see Michael P. Johnson, "Looking for Lost Kin," in Catherine Clinton, eds. Southern Families at War, 15-29.

186 The Third USCI's October 29, 1865, mutiny in Jacksonville against cruel Army disciplinary measures received similar coverage in the northeastern Florida press. For the best account of this incident, see John F. Fannin, "The Jacksonville Mutiny of 1865," The Florida Historical Quarterly, Vol. 88, No. 3 (Winter 2010), pp. 368-396.

${ }^{187}$ Philadelphia Inquirer, 6/13/65, “American Civil War Newspapers, 1840-1877,” Redex, https://infowebnewsbank-com.www.libproxy.wvu.edu/; "The Mutiny at Fortress Monroe," The Philadelphia Inquirer, 06-16-1865, Ibid.; "Norfolk. The Mutiny among Colored Troops. How it Originated! The Negroes Told They Were To," The Philadelphia Inquirer, 06-19-1865, Ibid.; "Unpaid Soldiers Their Families Suffering for the Necessaries of Life," New York Times, June 23, 1865, Ibid. (second quote)
} 
Other papers presented unfavorable views of the mutiny, promoting racial stereotypes.

The Daily Constitutional Union, of Washington, D.C., outright dismissed the grievances of the mutineers. Its account began with the assertion, "No matter what crimes the colored men commit, there are people who either justify or have an excuse for them." The Daily

Constitutional Union claimed that the black soldiers who mutinied at Norfolk previously, "had quite an easy time" of their duty. Rather than long marches and tough fighting, they had enjoyed "plenty of early vegetables and little work, except to stable their horses and keep themselves clean, if they knew how." The article continued to portray the mutineers as lazy: "All their dreams of bliss and ease were knocked in the head by the order of removal to Texas. This peremptory order was more than Sambo bargained for, as fighting was anticipated 'down dar." According to the Daily Ohio Statesman, in an uncorroborated account, the mutineers "ran riot through the town." In a lieutenant's unsympathetic postwar account, the First USCC mutineers got "wild drunk," becoming "half-drunken devils" and "wild beasts." 188 Accusations of black vice populated accounts of subsequent mutineers' revolts in the long emancipation.

More equivocal than other papers, the Crisis stated that it exhibited caution in its reporting on the mutinies against the Texas expedition. It revealed that its "correspondence abstained from giving publicity to exceptional cases" of mutiny in the Twenty-fifth Corps' cavalry brigade. The paper's motivation was to avoid "furnish[ing] food for the prejudice already existing against the employment of colored men as soldiers." However, the editor nevertheless considered the First USCC's mutiny notable enough to warrant detailed coverage. While seemingly sympathetic to African Americans elsewhere, the same column also reported on race

\footnotetext{
188 “The Colored Troop Mutiny," Daily Constitutional Union, 06-19-1865, Ibid. (quotes one through four); "Mutiny of Negro Troops," The Daily Ohio Statesman, 06-23-1865, Ibid. (fifth quote); Frederick W. Browne, "My Service in the U.S. Colored Cavalry," 1908, http://www.archive.org/stream/myserviceinuscol00brow/myserviceinuscol00brow_djvu.txt (sixth quote).
} 
riots in the surrounding region in ways that disapproved of the implications of emancipation:

"the negroes in Richmond are found to be so riotous, lazy and thieving that strong measures have been taken to quell them"; "the negroes in Maryland, under the teachings of Abolition, have become unbearable" by demanding land ownership. Among the headings of the column was "The African Elephant Becoming Troublesome"; it was unclear whether the editor used this animal imagery in reference to just the civilian riots or to the USCT mutiny as well. ${ }^{189}$

The Crisis's metaphorical use of an African elephant to symbolize black Americans formed part of a nineteenth-century racial discourse. In particular, it re-emerged during the white backlash to Radical Reconstruction. An 1869 article in the Daily Columbus Enquirer deeming African Americans mentally inferior referred to them as a "very dangerous and expensive African elephant on its [the Republican Party's] hands." The image that this language conveyed, of a large land mammal "becoming troublesome" likely spoke to the perceived gravity of the race question. It was a massive and potentially destructive problem for American society to resolve as it debated the proper status of freedpeople in the body politic and economy. Like the African species of elephant, this problem involved individuals with origins on the African continent who could crush institutions under its great weight. ${ }^{190}$

Newspaper coverage of black soldier mutinies thus allows us to explore American discussions on black citizenship in nineteenth-century America. For part of the press, a USCT mutiny was an unfortunate event for those who otherwise had performed well as soldiers and

\footnotetext{
189 "The Colored Gentlemen on the Rampage--The African Elephant Becoming Troublesome--Mutiny Among Negro Troops at Fortress," The Crisis, June 21, 1865, Ibid.

190 Ibid.; "Through the South," Daily Columbus Enquirer, November 13, 1869, Ibid. (quote). The "African elephant" in this case likely did not mean the now-popular Republican mascot, which did not become widespread until Thomas Nast's cartoons of the 1870s. For racial meanings ascribed to an Asian elephant species during the latter half of the nineteenth century, see Ross Bullen, "Race and the White Elephant War of 1884," The Public Domain Review, October 11, 2017, https://publicdomainreview.org/essay/race-and-the-white-elephant-war-of-1884; Sarah Amato, "The White Elephant in London: An Episode of Trickery, Racism, and Advertising," Journal of Social History, Vol. 43, No. 1 (Fall 2009), 31-66.
} 
who could look ahead to greater citizenship rights. Yet, for other publications, mutinies confirmed the notions of blacks' inherent character flaws, which only coerced labor could remedy. White southerners in the immediate postbellum period generally recognized that acts of defiance in which black troops violently asserted their autonomy and masculinity were instrumental as the country underwent the social revolution of the 1860s.

Threats to not just soldiers' families, but also their persons, fueled the wave of USCT mutinies immediately following the Civil War. The monotony plaguing the soldiers' new lives led to a lack of discipline that in turn provided African-American troops with concrete evidence that their early postbellum military service was degenerating into something comparable to bondage. An increase in intoxication and other forms of behavior deemed immoral by the military prompted white officers to intensify the discipline they imposed on the black rank-andfile for even minor infractions. The most hated punishment, tying up troublemakers by the thumbs while their feet were barely touching the ground, could be inflicted on a soldier who was sloppy on drill or failed to keep items clean in filthy Army camps. According to Richard Reid in his study of North Carolina-based USCTs, mutinies against such disciplinary methods suggest that, "the enlisted men were less willing to accept treatment in ways that they felt were inappropriate for soldiers and free men." While officers carried out cruel punishments during the war as well, they did so more frequently after Union victory. Moreover, the coming of peace told the men that this treatment no longer served military necessity; they had become used to the laxer discipline of combat zones; and they felt their wartime service had earned them a greater degree of freedom precluding punishments better suited for slaves. ${ }^{191}$

${ }^{191}$ Richard M. Reid, Freedom for Themselves, 288-289 (quote on 289); Joseph Glatthaar, Forged in Battle, 221-223. 
Though any army's transition from war to peace can create disciplinary problems, the addition of racial tensions into this case exacerbated the resulting animosities. As one soldier put it in a complaint to the Christian Recorder in the fall of 1865 , it was already detestable that their officers had asked them during the war, "to forget old grudges and prejudices, and fight like men for a common cause, meaning for us to not let the cruel and unjust treatment of the officers to the men...influence us to disregard for our duty." Now that these officers no longer needed to worry about dying on the battlefield, they, he continued, "are exercising all the arrogance and despotism that their power gives them." The soldier further wondered, "what appeals has an enlisted man if he applies for redress to the superior officer?" When Private John Ayers of the Forty-first USCI, a unit composed of Pennsylvanians, spoke out against the harsh disciplining of a comrade, he told a superior that, "you must think you are driving a flock of sheep." Such language illustrates the USCT view that their officers had become despotic and viewed them in dehumanizing terms, a clear sign that the freedom for which they had fought in the war was in jeopardy. Considering these disciplinary methods even more unacceptable now, and doubting that they possessed other avenues of redress, numerous USCTs mutinied. Though most still quietly endured the circumstances or formally protested, others felt that since their white officers had become greater tyrants, they had justification for revolting. ${ }^{192}$

Members of numerous USCT units rose up against perceived harsh discipline leading up to, during, and after the voyage from Virginia to Texas, as well as elsewhere in the newly conquered South. First, USCT camps in and around City Point experienced a great deal of mutinous activity in May and June 1865. Episodes saw men aggressively oppose the punishment

\footnotetext{
${ }^{192}$ H. S. Harmon to Mr. Editor, Christian Recorder, October 21, 1865, excerpted in Joseph Glatthaar, Forged in Battle, 222 (first, second, and third quotes); Proceedings of GCM, Trial of John Ayers, MM-2858, RG 153, NARA (fourth quote).
} 
of their comrades or conduct work stoppages. Just as the First USCC's mutiny compared with Civil War rebellions promoting the emancipationist goal of economic independence, the host of early postwar revolts against corporal punishment represented an outgrowth of the wartime mutinous campaign dedicated to another aim of the black liberation struggle: protecting black bodies from white abuse. The following examples illustrate how the strict discipline of the immediate postbellum months caused chain reactions of mutinous eruptions.

Two dozen members of the $116^{\text {th }}$ USCI, organized in Kentucky, were among the first to rise up against an officer who tied up comrades by their thumbs. The Army court-martialed the men for participating in, exciting, or for failing to suppress, the mutiny. Sergeants William Kease and Doctor Moore led fellow members of Company I in an armed demonstration on May 11, 1865, to the quarters of their commanding officer, Captain Sumner Warren, at City Point. The group demanded the release of Private George Seignior from the guard house, where Warren had confined him. Kease then refused to obey Warren's order to send the group back to its quarters. Rejecting his officers' authority, Private Robert Corperton encouraged the mutiny "by saying that he was glad it begun and that he was not going to be commanded by the damned white sons of bitches any more." Private Perry Hawkins declared that "I am in for taking him down and any man that is not in for it." He expressed his willingness "to help to kill all" and advised that "the company ought to go and help to take him down." Corporal Irvin Stone announced to a member of the guard that, "I am willing to go and to help untie him." Corporal Thomas Thumpkins endorsed the mutineers, stating that "They are right in doing as they do, and by God I am going to help them." Demonstrating his commitment to martial masculinity, Private Dudley Limes 
announced that "if this is the way colored soldiers are to be used, I would as well...die here as anywhere" for declaring his intention to help take his comrade down from the pole. ${ }^{193}$

The scene showcased the peer pressure common in the black military mutiny phenomenon, reminding African-American men of the tenet of republican ideology holding that their worthiness for freedom depended on their willingness to fight for it. For example, Private Clay Lilly called Corporal Samuel Maddox "a coward for his attempting to dissuade the enlisted men of his company from performing any mutinous actions." Corporals John Piper, Irvin Stone, and Monroe Hummerite, along with Private George Fishback, encouraged several comrades to assist the mutineers. They told their comrades, "Come boys get your guns let's go."194

Additionally, three New Yorkers in the Thirty-first USCI conducted their own mutinies in sympathy with those of the $116^{\text {th }}$. On May 11,1865 , Privates Henry Valentine, Maddison Coleman, and George Jacobs refused orders to quell the $116^{\text {th }}$ 's revolt. Commanded to fall in with his company for this purpose, the first declared that he, "didn't come here to fight against" his "own color and" was "not going to fall out for no man."195

These men's refusal to quell a mutiny highlighted a degree of inter-unit AfricanAmerican solidarity that had formed in the Union Army's Sable Arm. Even if their own unit did

\footnotetext{
${ }^{193}$ Proceedings of GCM, Trial of William Kease, Trial of Doctor Moore, MM-2394, Trial of Robert Corperton, Trial of Elijah Maker, Trial of William Shores, Trial of Maulies Coleman, Trial of James Griffin, MM-2858, Trial of John Bristow, Trial of Jacob Shepard, Trial of Andrew Taylor, MM-3125, Trial of Dudley Limes, MM-3067, Trial of Perry Hawkins, Trial of Thomas Thumpkins, Trial of John Johnston, Trial of Alfred Mack, and Trial of Evan Mack, OO-1184, RG 153, NARA. See Proceedings of a GCM, Trial of George Seignior, MM-3125, Ibid.

${ }^{194}$ Proceedings of GCM, Trial of Clay Lilly, Trial of John Piper, Trial of Irvin Stone, MM-2858, Trial of Monroe Hummerite, Trial of George Fishback, MM-3077, RG 153, NARA. During the period from the late night of May 11th to the early morning of May 12th, Captain Thomas P. Reiley ordered the corporal of the guard to arrest those who had conducted the mutiny of the previous afternoon. Jacob Shepard tried to persuade the latter against doing so and to thereby disobey the order, saying he knew "better than that." In the aftermath of the above revolt, another 116 th member acted mutinous in defense of the perpetrators. As he occupied the ranks of a parade ground, Private Henry Newton of Company G "did, in a threatening manner, remark that if we had fallen out with arms we would not have allowed those men to be marched off," referring to the arrested mutineers. After his own arrest, he refused to be quiet. See Proceedings of GCM, Trial of Henry Newton, MM-3077, RG 153, NARA.

${ }^{195}$ Proceedings of GCM, Trial of Henry Valentine, Trial of Maddison Coleman, MM-3125, Trial of George Jacobs, OO-1184, RG 153, NARA.
} 
not become mutinous, black soldiers still had a range of choices if one broke out nearby. They could refuse to suppress it, which aided its attempt to advance the emancipation process or they could agree to arrest or harm comrades struggling for more humane treatment, becoming complicit in white supremacy's campaign of keeping black bodies under the threat of force.

The extent to which African Americans enjoyed inter-racial solidarity boosted the prospects of the biracial democracy envisioned by African Americans in the 1860s. Among those prosecuted for the $117^{\text {th }}$ USCI's May 12,1865 , mutiny at Camp Lincoln, Virginia, a reaction against Lieutenant Colonel Hugh Hutchins disciplining all sixty men of Company $\mathrm{H}$ for four or five men's sloppiness during a dress parade, was the company's white commander. Using "contemptuous and disrespectful language" toward his superior, Major Edward Bacon, Captain Frank Doggett, who considered himself his men's "friend," protested the order for his company to remain standing at attention on the parade ground. He objected "to that manner of punishing a whole company for what a few have done" and demanded the authority to dismiss every nonoffender. For "criticizing the discipline of his commanding officer" in ear-shot of enlisted men and other officers, his court-martial charged him with inciting and encouraging mutiny. When a rowdy crowd of armed soldiers with fixed bayonets from the rest of the regiment subsequently formed to protest the mass reprimand and Doggett led his company back to its quarters, Major Bacon accused the captain of failing to participate in the effort to suppress the mutiny. For voicing his opposition to the excessive disciplining of the black rank-and-file during the early postbellum period, Captain Doggett received a conviction and dishonorable discharge. ${ }^{196} \mathrm{~A}$ white officer serving as an accomplice to a black mutiny illustrated the extent to which biracial alliances formed during the long struggle for emancipation. White allies not only sympathized

196 Proceedings of GCM, Trial of Frank Doggett, MM-2906, RG 153, NARA. 
and bonded with black troops and advocated lesser punishments under their prescribed authority, but also risked their own careers defending them in the midst of an episode.

The early postbellum wave of mutinies moved to a new stage while the Twenty-fifth Corps was en route to Texas, from late May to late June 1865. Many in the corps still opposed the journey because it entailed a boring, unsanitary voyage to a place far from their families. Soldiers who undertook the nearly-two-thousand-mile journey suffered from seasickness, cramped quarters, inadequate and insufficient rations, and continued harsh discipline. Such conditions bred disease and malnourishment, killing as many as twelve men every day in the $115^{\text {th }}$ USCI. After restocking and re-fueling at Mobile Bay, the corps sailed for the island of Brazos Santiago at the mouth of the Rio Grande. The destination's rough water and the Army's few boats added further misery to the soldiers' conditions. By the time the already agitated USCTs began sailing from Virginia to Texas, persistent white officer injustice and poor material conditions made a mutiny on the ocean ever more likely. ${ }^{197}$

Among those who revolted during the voyage to Texas were the Kentuckians of the $109^{\text {th }}$ USCI. Like the rest of their corps, these troops thought they had achieved freedom from white domination. However, events during the journey created a sentiment that their officers sought a new racist order. The 109th's mutineers reluctantly agreed to set sail but could not contain their frustrations once conditions deteriorated on the troop transports. Their seaborne mutiny followed a familiar pattern: first, officers punished enlisted men; next, mutineers tried to free the victims of the punishment, during which they made incriminating statements; and finally, the officers stepped in to suppress the revolt and try perpetrators.

\footnotetext{
197 Ted Tunnell, Edge of the Sword: The Ordeal of Carpetbagger Marshall H. Twitchell in the Civil War and Reconstruction (Baton Rouge: Louisiana State University Press, 2000), 83-84; Joseph Glatthaar, Forged in Battle, 218-224; Richard Reid, Freedom for Themselves, 264-266.
} 
Aboard a troop transport named the Thomas A. Scott, off the Gulf Coast, a group from the $109^{\text {th }}$ joined together to force the release of Privates Allen Johnson and Armistead Martley.

During an earlier inspection, a captain had arrested Johnson and Martley for failing to clean their guns, an offense constituting neglect of duty. When Lieutenant James Dony arrived to guard the two soldiers, they repeatedly insulted him and provided him with false names. This insubordination prompted the officer to tie them up by the thumbs. ${ }^{198}$

Angered at such treatment, a detachment of fifteen to twenty soldiers from the regiment's various companies decided to try to free Johnson and Martley, who endured their punishment on the rear side of the vessel. At least one mutineer expressed the group's view that the chosen punishment for Johnson and Martley did not fit the crime. Prior to the mutiny, Private Edwin Hawes remarked that no one aboard the "damn dirty boat" could adequately clean their guns. ${ }^{199}$ Due to this objection, the mutineers marched to their officers' quarters. Sergeant Samuel Green reportedly asked to see Captain A. H. Keene. Leading the group of mutineers to Keene, Green, "in a noisy manner," demanded that Keene release Private Johnson. Green threatened the captain that if the officers did not release Johnson, the soldiers would "raise the devil." After Keene and other officers ordered the group "to go back" and commanded Green to "quiet the men" and return them to their quarters, the mutineers decided to free the prisoners themselves. ${ }^{200}$

The mutineers made various hostile statements to the officers guarding Johnson and Martley. Privates Sheldon Penock, James O’Banan, and William Murrell armed themselves and repeatedly threatened to shoot anyone who interfered with their attempt. Murrell stated he was prepared to die in the effort to free Johnson and to blow up the boat. While Lieutenant John M.

\footnotetext{
198 Proceedings of GCM, Trial of Allen Johnson, Trial of Armistead Martley, MM 3244, RG 153, NARA.

199 Proceedings of GCM, Trial of Edwin Hawes, MM 3244, RG 153, NARA.

${ }^{200}$ Proceedings of GCM, Trial of Samuel Green, MM 3244, RG 153, NARA.
} 
Shoemaker tried to "quell the disturbance," Private George Mudd threatened the lives of the officers if they failed to release the two. When the mutineers finally approached Martley and Johnson, Penock called out, "untie the prisoners!” Using a knife Private John May acquired, the group cut Johnson's bounds loose. However, the mutineers failed to free Martley. ${ }^{201}$

The regiment's officers eventually restored order; the mutineers dispersed and returned to their quarters. After the tensions calmed down and some officers went to bed, a colonel worried that the men "may rise again." The next day, the officers arrested thirteen alleged mutineers. That autumn, the U.S. military court-martialed the suspected mutineers. ${ }^{202}$

A closer look at the socioeconomic backgrounds of the $109^{\text {th }}$ USCI's mutineers, followed by another set of witness statements, helps us better grasp how these men understood their role in the long black freedom struggle. Like other black mutineers, they believed that liberty meant the ability to live independently without coercion, harassment, and abuse from white overlords, especially after Union victory. Unlike USCTs from the Deep South, however, the soldiers of units recruited from the border states, including the $109^{\text {th }}$ 's Kentuckians, arrived at this notion of freedom in ways that reflected the region's unique ordeal with bondage and liberation.

The $109^{\text {th }}$ USCI's mutineers emerged from Kentucky's slave system. Its proximity to the North meant a shorter path to free territory. Like other states with a surplus of enslaved labor, the

\footnotetext{
${ }^{201}$ Proceedings of GCM, Trial of Sheldon Penock, Trial of James O'Banan, Trial of William Murrell, Trial of Peter Blinco, Trial of George Mudd, Trial of Samuel Green, Trial of Sandy Fenqua, Trial of Jake Mattingly, Trial of Henry Rector, Trial of Edwin Hawes, Trial of John May, MM 3244, RG 153, NARA. Echoing Privates Henry Valentine and George Jacobs from earlier in the chapter, a number of those on deck during the mutiny did not participate, but instead condoned it through refusals to follow the orders of the white officers to interfere with the revolt. When Lieutenant Dony and Corporal Allen Robinson of the Eighth USCI ordered Privates Frank Lancaster and Stephen Ritchie to load their weapons and suppress the mutiny after the soldiers released Johnson, they both declined. Lancaster declared that he served in the Army to "shoot rebels," not his comrades. See Proceedings of GCM, Trial of Frank Lancaster, Trial of Stephen Ritchie, MM 3244, RG 153, NARA.

${ }^{202}$ Proceedings of GCM, Trial of Sheldon Penock, Trial of James O'Banan, Trial of William Murrell, Trial of Peter Blinco, Trial of George Mudd, Trial of Samuel Green, Trial of Sandy Fenqua, Trial of Jake Mattingly, Trial of Henry Rector, Trial of Edwin Hawes, Ibid., MM 3244, RG 153, NARA.
} 
Bluegrass State participated in the domestic slave trade. Matching the general experience of American slavery, ill-disciplined bondspeople in Kentucky endured punishments such as whippings, brandings, and tying up by the thumbs. The state also cracked down on the autonomy of its small free black population. Laws disfranchised them and restricted their physical mobility. Free blacks also faced the prospect of enslavement if they failed to prove their free status and/or were kidnapped by slave traders. ${ }^{203}$

The mutineers of the 109th and their conception of freedom were also products of their home state's wartime experiences. The federal government initially tried to protect the peculiar institution to prevent the border states from seceding. However, the constant stream of runaways to Union lines gradually undermined slavery in 1862 and 1863. Since the Emancipation Proclamation freed bondspeople only in Rebel territory, it did not apply to any Union slave state. Slavery legally survived in the Bluegrass State until the Thirteenth Amendment's ratification. However, developments on the ground nevertheless weakened Kentucky's slave system over the course of the war. After first hiring slaves to work on fortifications, the Union Army in Kentucky next recruited black troops, assembling enough to form three regiments, including the 109 th. $^{204}$

These black regiments typically consisted of three main types of men: runaway slaves, those who enlisted under the Slave Claims Commission, and free blacks. ... and three fellow

\footnotetext{
${ }^{203}$ For the classic work on free blacks in the slave South, see Ira Berlin, Slaves without Masters: The Free Negro in the Antebellum South (New York: Pantheon Books, 1974). For Kentucky's experience with slavery, see James A. Ramage and Andrea S. Watkins, Kentucky Rising: Democracy, Slavery, and Culture from the Early Republic and the Civil War (Lexington, Kentucky: University Press of Kentucky, 2011), chapter 11, 260; Hanford Dozier Stafford, "Slavery in a Border City: Louisville, 1790-1860" (Ph.D. dissertation, University of Kentucky, 1987), 24, 37, 58.; Marion Brunson Lucas, A History of Blacks in Kentucky: From Slavery to Segregation, 1760-1891 (Frankfurt: Kentucky Historical Society, 2003), 108-117. The Kentuckians of the $109^{\text {th }}$ USCT who revolted aboard the Thomas A. Scott in June 1865 ranged in age from eighteen to thirty-five years old. Those who stated "farmer" as their occupation would have helped produce Kentucky's hemp crop. See 1860 U.S. Census; $109^{\text {th }}$ USCT Service Records, NARA, www.fold3.com.

${ }^{204}$ Victor Howard, Black Liberation in Kentucky: Emancipation and Freedom, 1862-1884 (Lexington, Kentucky: University Press of Kentucky, 1983), 30-40, 43-44, chapters five and six; Ramage and Watkins, Kentucky Rising, chapters four and eleven, 64 .
} 
mutineers were among the fugitive slaves who enlisted. As a runaways, they already had experience with rejecting white authority. By voluntarily joining the Union Army, black Kentuckians like him asserted the right to live according to their own will. ${ }^{205}$

Meanwhile, Sandy Fenqua, Sheldon Penock, and five other mutineers left bondage and either voluntarily or involuntarily joined the Union Army under the Slave Claims Commission. Created by General Order No. 329, this program allowed masters to manumit their slaves for the purpose of enlistment and to later claim monetary compensation. The master received a $\$ 100$ bounty immediately and a promised payment of $\$ 300$ after the war. For the latter, they needed to demonstrate loyalty to the Union and ownership over the enlistee. Almost 2,500 other Kentucky slaveholders applied through the commission. The record shows that the federal government rejected all six claims made by the ex-owners of the above mutineers. Though the documents lack specifics, the applicants likely failed to acquire witnesses confirming a Unionist allegiance. Since the program could enlist a slave without his consent, it constituted another instrument of white coercion comparable to conscription. However, if one wished to serve, he might have concluded that his master's permission ensured a safer path to the Army, as bondsmen who decided to join the Union Army risked murder or injury at the hands of masters and white mobs. Either way, the manumitted remained free even with a rejected claim, and by the time of his revolt, Fenqua and the other mutineers sought freedom from white control and abuse. ${ }^{206}$

Finally, the record also reveals that three mutineers, including Private Henry Rector, came from Kentucky's antebellum free black population. It is not clear whether they became free

\footnotetext{
2051860 Census; Stephen Ritchie Service Record, Samuel Green Service Record, Jake Mattingly Service Record, NARA, www.fold3.com.

${ }^{206}$ The Records of the Bounty and Claims Division, RG 94, NARA; 1860 Census; Sandy Fenqua Service Record, Sheldon Penock Service Record, James O'Banan Service Record, Peter Blinco Service Record, William Murrell Service Record, Frank Lancaster Service Record, and George Mudd Service Record, NARA, www.fold3.com.
} 
at birth or later in life. Regardless, they had tasted emancipation by the time of the war's outbreak. However, the subordinate social position of free blacks meant that they had as much of a stake in ending white oppression as those who experienced slavery their entire lives. ${ }^{207}$

Despite their three different paths to emancipation, a full year of military service and comradery helped the men of the $109^{\text {th }}$ forge a common conception of freedom. The regiment first served as a military occupation force in their home state. In October 1864 , the $109^{\text {th }}$ received orders to join the Army of the James in Virginia. Here, the unit mostly performed garrison duty, before eventually participating in combat operations that helped break the Petersburg stalemate. ${ }^{208}$

A source of racial animosities leading to the $109^{\text {th }}$ 's mutiny was a dispute over the regiment's black chaplain, Francis A. Boyd. Born enslaved in Lexington in 1843, Boyd acquired manumission by the eve of the war, worked as a house servant, and joined Louisville's white First Christian Church. Prior to enlisting in the Union Army, Boyd's white Unionist pastor appointed him as a missionary to contrabands. In 1864, he developed a calling to become a chaplain in the new black army being formed to help destroy slavery and preserve the Union. Colonel John Hammond assured Boyd he would be the $109^{\text {th }}$ USCI's chaplain following his enlistment in June. In November, General Benjamin Butler officially appointed Boyd in this role. However, that position went to a white clergyman instead; the regiment's white officers, whom Boyd claimed had "dark" and "bitter" prejudices, opposed the appointment, and the War

\footnotetext{
${ }^{207}$ Henry Rector Service Record, John May Service Record, Edwin Hawes Service Record, NARA, www.fold3.com.

${ }^{208}$ Orion A. Bartholomew Service Record, NARA, www.fold3.com; Dudley T. Cornish, The Sable Arm: Black Troops in the Union Army, 1861-1865 (Lawrence, Kansas, University Press of Kansas, 1956), 282; Ted Tunnell, Edge of the Sword, 83-84; A. Wilson Greene, The Final Battles of the Petersburg Campaign: Breaking the Backbone of the Rebellion (Knoxville: University of Tennessee Press, 2008), 381; "Report of Colonel William W. Woodward," April 27, 1865, in O.R., Volume 46, Chapter 58, Part 2, 1242; Report of Maj. Gen. Godfrey Weitzel," April 17, 1865, O.R., 1227.
} 
Department revoked it because he was not elected to the position by regimental officers.

Asserting that he as a black man possessed the same abilities as whites, and citing the favorable testimony of his Christian Church ministers, Boyd protested at each level of the military command. He considered the rejection "an insult to me, and my race." He wrote that African Americans were, "the only people who were loyal as a class in the United States" and therefore, "if any among them rose upon their merits, no one had a right to try, to defraud them out of their office.” By late 1865, he never convinced his superiors to award him with the chaplaincy. ${ }^{209}$

Coupled with the frustrations of remaining in uniform after winning the war and the harsh disciplinary climate of the postwar Army, Boyd's unsuccessful struggle to become chaplain added an extra dose of racial tension to life in the ranks of the $109^{\text {th }}$. Just as white commanders prevented black troops from beginning new lives as free civilians who could care for one's family, they also blocked Boyd from realizing his potential in his chosen occupation. In each case, white authorities restricted African Americans from acting according to their will. Tensions reached such a level that some members of the regiment rose up in defiance against the latest and most egregious example of white officers exerting unwarranted control over black soldiers' lives.

The mutineers' trial transcripts record the racial language they used to express their conception of freedom, which centered on black autonomy. In the midst of the attempt to free his comrades, Private Sandy Fenqua called the officers "white sons of bitches" who have "lied to us long enough.” This angry reference to dishonesty can be traced to resentment over his officers preventing him from enjoying his new freedom. ${ }^{210}$ Fenqua's language also reflects the hostility towards whites he developed under slavery and in the Army. He proclaimed that "he would not

\footnotetext{
${ }^{209}$ Francis A. Boyd to Benjamin Butler, Nov. 4, 1864, Francis A. Boyd to Benjamin Butler, Jan. 5, 1865, Francis A. Boyd to Andrew Johnson, May 12, 1865, Francis A. Boyd to A. Lincoln, Feb. 25, 1865, in Ira Berlin, The Black Military Experience, 350-354.

${ }^{210}$ Proceedings of GCM, Trial of Sandy Fenqua, MM 3244, RG 153, NARA.
} 
allow any white man to run over him," since "he never allowed his master to!" Fenqua thereby connected a refusal to tolerate prejudice in the Union Army with bondspeople challenging the power relationship central to slavery. Secondly, he implied that he previously clashed with his owner. In both slavery and the military, Fenqua resisted white abuse to advance his freedom. ${ }^{211}$

Condemnations of their officers for thinking "they can do just as they please with us" and similar quotes populate the trial transcripts of Sandy Fenqua, Sheldon Penock, and three others. These suggest that the mutineers thought their superiors infringed on their personal independence. Thus, the mutiny formed a part of a broader struggle to protect all African Americans from white behavioral constraints. Angry over such mistreatment, Penock declared that he would, "be damned if he wouldn't go with any of the boys to untie the prisoners."212 Citing Private Henry Rector's persistent demands for the prisoners' release, a lieutenant testified that Rector was "one of the foremost ones engaged" in the incident. When the officers ordered the mutineers to disperse, Rector denied the former's authority to instill discipline. ${ }^{213}$

The comments of James O'Banan, Samuel Green, and Jake Mattingly on the harsh disciplinary measures specifically emphasize the USCT belief that their new status should spare them of physical abuse that recalled bondage. O'Banan proclaimed, "We will see if these officers are going to tie up a colored man. We are free, our Colonel [Bates] told us so, and we will fight before they shall keep our men tied. They had better release that I tell you!" Both Green and Mattingly pointed to how they and their comrades "came away from home to [be] rid of such treatment as this." They highlight the soldiers' understanding that service in the Union Army freed them, which meant that cruel treatment violated the terms of their emancipation and

\footnotetext{
${ }^{211}$ Ibid.

${ }^{212}$ Proceedings of GCM, Trial of Sandy Fenqua, Trial of James O’Banan, Trial of George Mudd, Trial of Sheldon Penock, and Trial of Peter Blinco, MM 3244, RG 153, NARA.

${ }^{213}$ Proceedings of GCM, Trial of Private Henry Rector, MM 3244, RG 153, NARA.
} 
contradicted the free status they held as they understood it. Revolting against their current white superiors represented the next stage of their effort to establish a world in which African Americans could exert control over their circumstances without the threat of white violence. ${ }^{214}$

After U.S. Army officials finished administering the courts-martial in the fall of 1865 , they acquitted four and convicted nine of the accused. All of those sentenced forfeited their pay and performed hard labor with a twenty-four-pound ball attached to one leg for either the remainder of one's three-year term of service or a set number of months. Most toiled at Dry Tortugas, a remote island off the coast of Florida. All of those who received the maximum sentences were released early, by February 1867, as their unit at last mustered out. Those soldiers who departed from the military justice system without a guilty verdict benefitted from comrades who testified in their defense that they did not participate in the mutiny, or from convincing the general courts-martial that they cautioned against the men freeing the prisoners. ${ }^{215}$

The cycle of perceived injustices followed by ill-discipline and mutiny continued to shape the experiences of the Twenty-fifth Corps' USCTs after landing in Texas in mid-June 1865 , lasting until near the end of the sixteen-month deployment. Part of the reason was that the unfortunate conditions plaguing the voyage followed the soldiers to land. The military post on

\footnotetext{
${ }^{214}$ Proceedings of GCM, Trial of James O’Banan, Trial of Samuel Green, Trial of Jake Mattingly, MM 3244, RG 153, NARA.

${ }^{215} 109^{\text {th }}$ U.S. Colored Infantry Service Records, NARA, www.fold3.com; Proceedings of GCM, MM 3244, RG 153, NARA. As Sheldon Penock suffered the consequences of his revolt, his ex-master, B. W. Penock, wrote to the president in April 1866 to petition for the former's early release. He pointed to the "strong affection" the two formed as master and slave. The Judge Advocate General recommended remission of Penock's sentence, citing "the impulse of humanity." This letter demonstrates the continuation of the antebellum paternalism ideology stating that the slaveholder acted as a benevolent father figure for his perpetual children. See W. Penick to Honor. Andrew Johnson, April 16, 1866, filed with A-111 1866, Letters Received, ser. 360, Colored Troops Division, RG 94 [B-209], in Ira Berlin, The Black Military Experience, 471-473. For a detailed discussion of paternalism, see Jeffrey Robert Young, Domesticating Slavery: The Master Class in Georgia and South Carolina, 1670-1837 (Chapel Hill: University of North Carolina Press, 1999), 123-160. For another mutiny against the tying up of a comrade's thumbs featuring death threats and usage of racial profanity, this time involving the $103^{\text {rd }}$ USCI, see Proceedings of GCM, Trial of Alexander Benjamin, MM 3707, RG 153, NARA. The bloodiest example of this type of mutiny involved the Third USCI in Jacksonville in October 1865. See John F. Fannin, "The Jacksonville Mutiny of 1865."
} 
the island of Brazos Santiago gave the troops insufficient and inadequate water, food, and supplies. Making matters worse, they faced countless other miseries—seclusion, heat, sand, snakes, insects, gulf storms, and disease. As one chaplain put it in October, during the previous summer, no "set of men in any country ever suffered more severely than we in Texas." The growing of fruit and vegetables beginning in late August improved overall health by 1866 . Yet, Texas never stopped bringing high temperatures, filth, exhaustion, and loneliness. The Twentyfifth Corps soldiers on Brazos held an isolated slice of territory far from Reconstruction's white violence and government assistance to freedpeople. Meanwhile, those who occupied the border town of Brownsville fifteen miles away interacted with hostile white civilians, like other federal troops throughout the postwar South. Rather than enjoy peacetime as freedpeople, AfricanAmerican soldiers along the Rio Grande in the year following war's end endured an unforgiving landscape and a painful separation from their families living on the other side of the continent. ${ }^{216}$

To be sure, USCTs were not the only Union Army veterans to resent postwar service to such an extent that they mutinied. In early 1866, various white units in Texas did so partly in response to others mustering out before they could while they continued the monotony of garrison duty in a harsh natural environment. Just as they had during the Civil War, white units resented unfavorable unit organization. As the Army gradually mustered out those who had served the longest, it merged the reduced regiments as battalions, bringing together troops without preexisting camaraderie. In March, the homesick, demoralized men of the Forty-eighth Ohio Infantry Battalion, the product of three weakened veteran regiments, conducted a work stoppage, stacking their weapons and refusing to continue their duties. In contrast to USCTs who mutinied at the time, these white Ohioans all received honorable discharges and avoided court-

\footnotetext{
${ }^{216}$ Richard Reid, Freedom for Themselves, 267-268, 271-272 (quote on 268); Joseph Glatthaar, Forged in Battle, 219-220. For more on clashes pitting white civilians and black federal forces, see the next chapter.
} 
martial proceedings. Additionally, to their jubilation, the remaining Civil War volunteers

mustered out once regular forces could replace them. ${ }^{217}$

Other white U.S. forces revolted for reasons familiar to USCTs. While stationed in Austin in February 1866, the First Iowa's cavalrymen devised a mutiny against their commander George Armstrong Custer's physical mistreatment of them. Among their grievances were his fondness for upholding discipline through whipping, withholding rations, and ordering them to act as his wife's servants. They planned to fire their carbines from concealed positions. However, General Custer learned of the ambush plot, prompting him to leave early. While it is unknown which punishments, if any, the Army gave the anti-Custer mutineers, they represent a continuation of a wartime trend. Both blacks and whites in blue suffered, and rebelled against, degrading abuse, but for the former, it could not be separated from the legacy of slavery. Moreover, as the two above cases are among a few known white mutinies in the immediate postbellum months, they paled in comparison to USCT rebellions in scope and frequency. ${ }^{218}$ The horrid conditions of Army life in early postbellum Texas leaves little wonder as to why black and white soldiers in numerous regiments mutinied along the Rio Grande.

However, diverse treatment along the Rio Grande helped explain which conditions were necessary to cause a black soldier mutiny and which reduced its likelihood. When regiments served in Texas under softer discipline, like the Thirty-sixth USCI did, they avoided the acute

\footnotetext{
${ }^{217}$ Richard Reid, Freedom for Themselves, 68; William L. Richter, The Army in Texas During Reconstruction, 1865-1870 (College Station: Texas A\&M University Press, 1987), 25-28. At least one member of the Forty-eighth Ohio, Private Thomas J. McCane was tried and sentenced to three months of hard labor for a mutinous incident. However, it resulted from alcohol-infused disorderly conduct in July 1865. See Proceedings of a GCM, Trial of Thomas J. McCane, MM-2858, RG 153, NARA.

${ }^{218}$ Richard Reid, Freedom for Themselves, 68; Charles H. Lothrop, A History of the First Regiment Iowa Cavalry Veteran Volunteers, from Its Organization in 1861 to Its Muster Out of the United States Service in 1866 (Lyons, Iowa: Beers and Eaton Printers, 1890), 294-97. Also see Proceedings of a GCM, Trial of William Covey, MM-2858, RG 153, NARA. Private William Covey of the Twenty-third Iowa Volunteers spent three months performing hard labor for striking his commanding officer in a summer 1865 mutiny.
} 
dissent that struck others. Regimental commander Major William Hart assigned camp police duties to noncommissioned officers of the day, conveying trust to his men. To foster cooperation in upholding order, Hart held competitions in which he gave the company that performed the best at cleaning their quarters a week off from fatigue duty. In their camp on Brazos Santiago, the Thirty-sixth ate better, stayed healthier, and lived in superior quarters compared to other black regiments in the area. Inspection reports reveal that the fortunate Thirty-sixth continued to enjoy higher morale than other units despite being among the last regiments to occupy the Lone Star State. ${ }^{219}$ Even when performing an unpopular duty in a harsh landscape, when AfricanAmerican troops felt valued and appreciated, they tended to avoid acting mutinous.

Yet, since other white officers were stricter and crueler than William Hart, black soldier mutinies kept the military justice system busy throughout the Texas border region. A member from the Thirty-first USCI mutinied near White Ranch, Texas. On June 10, 1865, Private Richard Mills went into custody for rejecting orders to surrender his musket and stop talking. Connecting his current military service to his past experience with slave resistance, Mills was quoted as saying, "I whipped my master man once he whipped me afterwards but he had to get help to do it I am not afraid of any one white man - all I want is to get out of the army, or, my rights.” Though his regiment consisted of New York and Connecticut residents, Mills' reference to slavery suggests that he was a bondsman who fled north. While the specific words mutineers used in Virginia and the Gulf of Mexico tended to be indirectly tied to the acute USCT desire to quickly muster out, Mills clearly cited this desire and directly connected it to black resistance to

\footnotetext{
${ }^{219}$ Ibid., 270-272. For another example of why black soldiers who felt valued were less likely to mutiny while mistreated ones often rebelled, see Reid's comparison of the Thirty-fifth and Thirty-seventh USCI: Ibid., xv, 15, 3841, 67-93, 98-109, 111-112, 154, 164-169, 174-175, 187-216, 272-295.
} 
white supremacy. For bringing his rebellious spirit leftover from slavery to the U.S. Army, the private received a dishonorable discharge, pay forfeiture, and two-year hard labor sentence. ${ }^{220}$

Later, in March 1866, the wave of Texas mutinies increased in frequency. That month, Private Richard Lewis of the $117^{\text {th }}$ USCI reportedly threatened violence against Lt. David Bond in Brownsville as the latter attempted to arrest the former. Witnesses later claimed Lewis drew a knife from his pocket and told Bond "don't lay your hands on me, if you do I'll kill you."221 Private Jesse Gibbons, a substitute and also of the $117^{\text {th }}$ USCI, "did cause and excite a mutiny" in another company. He threatened to shoot Sergeant James Miller if he attempted to punish William Goldburough of Company D. In response to Sergeant Richards Grubbs' order to leave Company D's street, he proclaimed that "he would be G[o]d d[a]m[ne]d if he would."222

Furthermore, at Brazos Santiago, Texas, Private James Hall, of the Thirty-eighth USCI, drew his knife on his superior officer, First Lieutenant J. H. Russell, threatening that, "If you touch me, I'll put this into you." ${ }^{223}$ In March and April 1866, soldiers in the $114^{\text {th }}$ USCI, another Kentucky regiment, could not stay out of trouble in Brownsville. Privates John Stone, Dudley McQuarry, and Charles McFeeters stood trial for committing such acts as joining "with other soldiers of his guard in a mutinous disturbance," speaking to officers "in a contemptuous and disrespectful manner," and threatening to kill and physically assaulting superiors. ${ }^{224}$

The mutinies of the immediate postbellum Rio Grande region followed a familiar pattern. Privates Mills, Lewis, Givins, Hall, Stone, McQuarry, and McFeeters rose up, often violently,

\footnotetext{
${ }^{220}$ Proceedings of GCM, Trial of Private Richard Mills, MM-3125, RG 153, NARA. Later the same day as Mills' mutiny, Private Madison Colnell refused an order to report to his commanding officer's quarters, only doing so when the officer called on him again, because, as he explained, he knew the order would lead to a command to help tie up Mills. See Proceedings of GCM, Trial of Private Madison Colnell, Ibid.

${ }^{221}$ Proceedings of GCM, Private Richard Lewis, OO-1561, Ibid.

${ }^{222}$ Proceedings of GCM, Trial of Jesse Gibbons, OO-1549, Ibid.

${ }^{223}$ Proceedings of GCM, Trial of James Hall, OO-1566, Ibid.

${ }^{224}$ Proceedings of GCM, Trial of John Stone, OO-1565, Ibid.; Trial of Dudley McQuarry, OO-1680, Ibid.; Trial of Charles McFeeters, OO-1589, Ibid.
} 
against their superiors for perceived abuses. When facing the hammer of the military justice system, they enjoyed due process rights. Rather than the maximum punishment of death, Mills, Hall, McQuarry, and McFeeters received the common mutineer trifecta of performing hard labor-Mills for two years, Hall for five years, and the latter two for remainder of their termsforfeiting all or almost all pay, and awaiting a dishonorable discharge upon release. Meanwhile, Gibbons was transferred to another regiment and lost pay for only twelve months. Judges acquitted both Lewis and Stone, confirming that the U.S. Army afforded an unprecedented degree of legal rights to its African-American soldiers. Regardless of the course of resulting court-martial proceedings, the first year of "peace" constituted a period of widespread revolt of USCTs against harsh Army discipline. The unforgiving circumstances of those ordered to Texas at each step, along with the never-ending perception that this ordeal resulted from racial animosity, ensured that this period lasted as long as the USCTs remained in uniform.

USCTs in different parts of the immediate postbellum South also revolted against harsh disciplinary measures. While the Texas force had an international mission, those kept in the rest of the conquered South assumed the role of keeping the peace, a function of northern uncertainty over how ex-Confederates would act. Comparable conditions that bred mutiny in both groups of early postbellum USCTs reveal that discontent with involuntarily staying in the ranks after Confederate defeat spread across the Sable Arm. ${ }^{225}$ The mutineers of this force included Ohio troops who enlisted in the Kentucky-based Twelfth USCHA.

While resembling the mutiny of the $109^{\text {th }}$ USCI in its causes and character, this other African-American revolt stands out through its demographic tensions, length, and rich court

\footnotetext{
${ }^{225}$ Ulysses S. Grant, The Civil War Memoirs of Ulysses S. Grant, Bryan M. Thomsen, ed. Single vol. abridgement and reprint of Personal Memoirs of Ulysses S. Grant. New York, Charles L. Webster Sc Co., 1885 (New York. Tom Doherty Sc Associates, LLC, 2002), 425.
} 
testimony. According to numerous witnesses at the resulting court-martial, each of the mutineers had been transferred from the Seventy-second Ohio Colored Infantry, which they joined in January 1865 just two weeks prior to the mutiny. The extent of the Twelfth USCHA's mutinous episode so shocked the judges presiding over the resulting trial that they described it as an "overt act" and "not something which may have taken place a year ago." This statement suggests that USCT mutinies became more aggressive after the Civil War, a function of the acute frustration over being unable to enjoy civilian life in the new, post-slavery Union. What helps explain this reaction is the testimony from a captain that the fort at which the mutiny took place was "highly disciplined" before the arrival of the Seventy-second's "Ohio men." Furthermore, officers described the incoming northerners as well-educated, smart, and influential among the preexisting men. Yet, the rank-and-file Kentuckians in the Twelfth considered these newcomers to be interlopers. Corporal George Frazier called them "strange men" whose character he could not determine. Another witness, the white sutler George Wright, could only identify one specific mutineer, Corporal James Carter, because the former was, "not acquainted with the squad of men from Ohio." These black troops could therefore relate to the collapse of white soldiers' esprit de corps during the early postbellum unit consolidations. ${ }^{226}$

Despite this language populating the court-martial trial testimony and sources confirming that half the mutineers had connections to Ohio, the current author has found no evidence that the Seventy-second Ohio Colored Infantry ever existed as a unit. According to their service records, every prosecuted mutineer was southern-born, with fourteen originally from Kentucky or other slave states. Five had escaped from slavery, and three were substitutes. Those of Company B joined the Twelfth at Camp Nelson in the summer of 1864, along with most

\footnotetext{
${ }^{226}$ Proceedings of GCM, Trial of James Thornton et. al., MM-3004, RG 153, NARA (quotes).
} 
members of the Kentucky-based USCTs. However, Company M's mutineers were recruited in the Ohio towns of Ironton, Columbus, Toledo, Cincinnati, Circleville, and Hillsborough during the winter of $1864 / 1865$. In mid-July 1865 , four Company M mutineers-Privates Henry Clay, Frank Stokes, Jerry Walters, and Charles Allen — reportedly transferred to the Twelfth USCHA from the Seventy-second USCI, organized in Kentucky due to an expiration in its members' terms of service. ${ }^{227}$ This evidence suggests that at least Company M's members had previously fled the slave South to live in the free North. Unless they inaccurately assumed the Seventysecond was an Ohio unit, that witnesses would conjure up a fictional black northern regiment to which they would subscribe the mutineers' membership speaks to how the "Ohio men" had a reputation as outsiders. Since no evidence connecting Company B to the Buckeye State exists, this group may constitute life-long southerners who sympathized with southern-born Ohioans. ${ }^{228}$ Whatever their backgrounds, in early August 1865, at Fort Boyle, near Colesburg, Kentucky, the mutineers of the Twelfth USCHA conducted a series of rebellious behaviors over the course of several nights, during which they tried to free an imprisoned comrade named Cornelius Taylor of Company M. In a single trial, the Army charged the following men with exciting, causing, or joining in a mutiny or sedition: James Thornton, Jeff Lisle, Charles Spotts, Alfred Roe, James Woodson, and Lyman Ferrill of Company B; and James Carter, Gibson Wormley, James Beach, Thomas Hodge, Henry Clay, Frank Stokes, Jerry Walters, John Williams, and Charles Allen of Company M. Taylor's offense was “improper language toward an officer," disrespectful behavior, "insulting language," and "insubordinate, mutinous conduct"

\footnotetext{
${ }^{227}$ According to the historical record, the only black volunteer regiment the Buckeye State produced was the $127^{\text {th }}$ Ohio Colored Infantry, which became the Fifth USCI.

${ }^{228}$ Half of the mutineers listed "farmer" as their occupation, with the rest being laborers or an undetermined type of worker. Except for one forty-five-year-old, the mutineers ranged in age from 18 to 28 , forming an average of 22.3 years. Civil War Service Records of the Twelfth U.S. Colored Heavy Artillery, Civil War Service Records of the Seventy-second U.S. Colored Infantry, NARA, www.fold3.com; James Bissland, Blood, Tears, and Glory: How Ohioans Won the Civil War (Wilmington, Ohio: Orange Frazer Press, 2007), 285, 319-321, 426, 450.
} 
over the course of several days. Taylor drew his officers' wrath after he recommended that a corporal use a light source to locate a missing cap and repeated the suggestion to the captain. When fort commander Captain H. T. Potter took "offense at the manner of the remarks," he kicked and arrested Taylor "considerably" before tying him up by the thumbs on the night of August 2. Taylor's weight broke the ropes. Potter then beat him in the face, spilling blood, before tying him up again. Captain Potter, while testifying for the prosecution, described Taylor as "a very bad man" who deserved this punishment because he, "became so mutinous." Potter wanted to "shut his mouth" and make him an example to the rest of the men. ${ }^{229}$

Those who mutinied on Cornelius Taylor's behalf on August 4 objected to this treatment due to a perceived underlying racial hostility that had no place in the new, emancipated Union. According to one witness' testimony, "I can see no reason for" this treatment "but that he is a black soldier." Defending the country's emerging biracial democracy, he added, "the laws of the country place them in exactly the same situation as regards the mode and quantity of punishment as any other soldier." He related that both his past brigade and division commanders-Major General W. B. Hazen and General William Nelson, respectively—were among the "strictest disciplinarians." However, never in his four years of service had he ever witnessed punishments so severe for so minor a crime, going beyond both Army regulations and practice. ${ }^{230}$

Declaring that Taylor had been tied up "long enough" and that "they would not stand that," referring to the above abuses, an hour and a half after the start of the punishment, the first set of mutineers arrived at the guard house. Numbering around a dozen, most came from Company M. Potter ordered the men back to their quarters. However, these men returned with

\footnotetext{
${ }^{229}$ Proceedings of GCM, Trial of James Thornton, et. al., MM-3004, RG 153, NARA. During the trial, Potter could not recall any specific words Taylor uttered.

${ }^{230}$ Ibid.
} 
loaded weapons and partially cut the rope attached to Taylor's thumbs before leaving. Under the camp's regulations, this action constituted an unlawful assembly because they lacked permission and because the officers prohibited loaded weapons. The men also proclaimed their intention to no longer obey their officers and threatened to kill anyone who interfered or touched Taylor. To determine the extent of the mutiny via a roll call, Potter ordered other soldiers from his Company B to form a line, sent guards to the barracks, and directed Captain Edmund Hulanski to have his Company $\mathrm{M}$ fall in. When Hulanski and his men gathered to quell the disturbance, the mutineers charged and pointed their weapons at him. Despite ringleader Corporal James Carter's efforts to keep the assault going, the men fell in when Hulanski fired an unloaded weapon at them. The officers arrested those with loaded weapons, which proved their involvement in the mutiny. ${ }^{231}$

Another, larger-scale mutiny largely involving Company B's members occurred the night of August 4. This accompanying revolt resulted from the officers carrying out another harsh punishment on Taylor. ${ }^{232}$ The former compelled the latter to lift a heavy stone. Angry comrades called on Taylor to drop it. As the situation escalated, an older sergeant reportedly commented that, "the boys are together for mischief tonight." According to court testimony, Charles Spotts, James Thornton, Alfred Roe, and Lyman Terrill were the most prominent figures in this second incident. During it, the soldiers all stated in similar language that "by God it's played out," meaning "they wasn't going to be punished anymore." With fixed bayonets, they moved up to the guard house. Upon learning that trouble was brewing, Lieutenant Robert Tyler arrived. Spotts told the lieutenant that he did not need to fear harm to himself, but he cursed Hulanski, Potter, and other officers. The angry squad convinced Taylor to drop the stone before freeing him.

\footnotetext{
${ }^{231}$ Ibid.

${ }^{232}$ While some witnesses at the court-martial exhibited difficulty distinguishing the revolts of August 2 and August 4 , others recognized them as distinct affairs.
} 
Fearing that their superiors planned to fire cannons at them, the mutineers next threatened to use the artillery on the officers, which non-mutineers, including Corporal Ransom Fry and George Wright, prevented. "This mutinous spirit was finally quelled" when Lt. Tyler demanded silence. An officer afterword placed Taylor in the guard house, and the mutineers went into custody. ${ }^{233}$

Though the regiment's commanders had quelled three mutinies thus far, the troubles had one more chapter. On August 6, with Potter absent and Hulanski still in command, a number refused to obey the latter's orders and demanded the release of several participants of the previous events. One soldier reportedly loaded his weapon and "brought it to bear...in a threatening manner." Hulanski immediately put the man in custody. Upon hearing this news, Potter became worried about the "spirit of insubordination" and determined that something needed to be done before the situation worsened. Meanwhile, Cornelius Taylor, the powder keg of the regiment's late-summer crisis, deserted. By the time of the trial, Taylor was still missing. ${ }^{234}$

During the multiple-part revolt in the Twelfth USCHA, those who decided against participating advised their rebellious comrades to be more pragmatic, which invited accusations of disloyalty and cowardice. One witness testified that he had told the mutineers to be careful and that, "it would not do any good even if they did get the upper hand of the officers because they could have aid from Louisville in a short time.” Sergeant Frank Shelton begged the men to peacefully leave the matter alone. Charles Spotts laughed at him, replying that "You undoubtedly must be appealing for the officers." Corporal George Frazier drew accusations of spinelessness when he informed Henry White, Alfred Roe, Jeff Leisle, Lyman Terrill, Jim Thornton, Taylor

\footnotetext{
${ }^{233}$ Proceedings of GCM, Trial of James Thornton, et. al., MM-3004, RG 153, NARA.

${ }^{234}$ Perhaps because the affairs of August 2 and 4 were larger and more chaotic by comparison, only Captain Hulanski's testimony in the trial transcript's nearly two hundred pages mentioned the August 6 mutiny.
} 
Williams, and Aaron Bufort, "about [him] not having anything to do with" the second mutiny and when he chastised their decision to disrupt their officers' duties. According to the mutineers, as many men as possible should prevent the officers from punishing them the way they have done Cornelius Taylor; the enlisted men were too numerous to permit such abuses. ${ }^{235}$ The debate centered on whether to engage in cautious self-preservation or to live up to the dangerous martial masculine ideal. As seen later, the clash over which option best promoted the emancipation process permeated African-American discourse and action deep into the next century.

The defense testimony sheds further light on the unit's disaffection with Cornelius Taylor's punishment while also trying to foster doubt about the validity of the charges facing the defendants. Corporal Lewis Ries of Company M told the court-martial that James Beach and Thomas Hodge performed guard duty when ordered to fall in with the others on the first night of the disturbances. Like the mutineers, Ries had transferred from the Seventy-second USCI to the Twelfth USCHA, enlisting in Cleveland. While denying that he heard comrades discuss rescuing Taylor, he did listen to remarks in the barracks at night that Taylor did not deserve being tied up. In frequent responses during the defense component of the trial, the witnesses pled ignorance about numerous occurrences, sights, and sounds, including statements from comrades and their locations. The witnesses on both sides repeatedly revealed that they could not recognize mutineers due to darkness, distance, and unfamiliarity. One defense witness wondered whether enough solid evidence, minus hearsay, existed that would enable a witness to identify anyone. ${ }^{236}$

A written statement the defendants' attorney, J. H. Ward, gave in the mutineers' defense offers their views on racism in the country at large and in the Army particularly, as well as an understanding of judicial process and rights. The document identified inconsistencies and

\footnotetext{
${ }^{235}$ Proceedings of GCM, Trial of James Thornton, et. al., MM-3004, RG 153, NARA.

${ }^{236}$ Ibid.
} 
imperfect memories in the prosecution's narrative. It also used the chaotic nature and extenuating circumstances of the mutiny to further establish reasonable doubt. Ward discussed Shelton's prejudice against the "Ohio men," or "Ohio party." This prejudice, the document asserted, formed "one of the causes of the war," and "the successful issue of the contest" "entirely obliterated" this prejudice. However, it persisted in this black regiment and was being directed toward "not only those here on trial but those whose testimony has been given in this case." The statement called into question testimony using the verb "supposes." It noted that due to the hurried nature of the trial, the defendants had been unable to corroborate their notes and memory with those of the recorder. A number of the prosecution's witnesses only identified the defendants at points in time apart from the mutinous affairs. According to the counsel, key defense witnesses were absent. The document further asked the court to consider whether a soldier possessing a loaded weapon justified the death penalty, since this fact could originate from the incident's confused, excited circumstances, or from the order to fall out. The scene's darkness meant that another armed person whom no one noticed could have been present. Ward wondered whether the officers who testified might have had faulty memories. Moreover, he noted, Lt. Tyler and the ordinance sergeant each failed to recognize anyone who moved towards the guard house. Contradicting how officers generally understood mutiny, the attorney disagreed that Charles Spotts' verbal objections to the harsh discipline of his comrade constituted a crime. Overall, the attorney emphasized the high standard of conclusiveness required for evidence in courts martial, evidence which excludes all other possibilities, probabilities, and theories.

The legal strategy of the defense was partially successful. In the trial, held in late August, the court acquitted Thomas Hodge, Charles Allen, Henry Clay, Frank Stokes, and Jerry Walter. They were thus released and restored to service. Those convicted and sentenced to death by 
firing squad were James Thornton, James Carter, Gibson Wormsley, James Beach, Charles Spotts, Alfred Roe, Jeff Lisle, James Woodson, and John Williams. ${ }^{237}$

Commenting on this case, Judge Advocate General William H. Coyl discussed the legal philosophy behind mutiny prosecutions, which confirms the current work's theoretical definition of mutiny. As he put it, Coyl heard no argument proving the innocence of the accused, and the events did indeed constitute a mutiny. It was not proper for either the official or the court to determine whether Cornelius Taylor's punishment was justified. The court is to only decide who encouraged, and participated in, the mutiny and why they did so. The general cited O'Brien, "American Military Law and Courts-Martial," page 72. Under the law, in the case of a mutiny, sedition, riot, or any other unlawful action, every participant, not just the leader and regardless of intent, is responsible for the criminal acts that result from the offense. Those who incited or joined a mutiny shared culpability and deserved an equal sentence. The only persons deserving leniency were the "misguided and deluded tools of factions and unprincipled men." Such persons contrasted from "those, who, by their guilty machinations, have urged others to the commission of a crime of such magnitude." Further guiding the court was recognition that under the Articles of War, even if someone uttered the "merest word" against lawful authority and had the most minor involvement in an incident, he was guilty of mutiny and subject to any punishment decided by the court martial, even the most severe type. The punishments for mutiny served to promote social order, reminding all current and prospective soldiers that their primary duty centered on obedience. The Twelfth USCHA's rebellion constituted a mutiny because participants subverted the military hierarchy, regardless of the extent to which they did so, prompting officers to desperately re-establish their superiority. ${ }^{238}$

\footnotetext{
237 Ibid.
}

${ }^{238}$ Ibid. 
General Coyl challenged the mutineers' view that their commanders threatened the terms of their emancipation. He interpreted the defendants' accusations of racial discrimination as "a little to gross a mistake" and as the product of demagoguery. If any officer mistreated them for racial reasons, he was not representative of the general Army experience or of its customs. The judge advocate contended that the prosecution tried the defendants only based on their violations of the law, not their race. Article 7 of Army law dictates that anyone who commits or incites a mutiny faces the death penalty or any other punishment decided by a court-martial. According to the author's understanding of the custom of the service "from time immemorial," and before the enlistment of black soldiers, all mutineers should be shot. Moreover, this custom would remain in the future, when everyone in the present has passed away and "when negro soldiers shall have been a permanent and fixed thing." Since the accused men were U.S. soldiers, "We have certain responsibilities towards them, and they have certain responsibilities towards us." A soldier's primary duty is to obey his superiors in all circumstances. When mistreated, they have remedies besides disobedience. In the case of the defense's absent witnesses, Thomas Carter and James Breach, the court overruled their affidavits because their applications failed to include their location at the time of the second mutiny, invalidating it. Furthermore, nothing in the affidavit would have benefitted the prisoners, for the official could have disproven them and the two witnesses, "were engaged from the first part of the mutiny."239

While the Advocate General may have given a strong case for racially-blind justice, he nevertheless overlooked the men's perspective. Given their abuse and the fragile status of their freedom, it was not too farfetched for them to assume that worse treatment, such as artillery fire, was in store for them, comparable to the rumors of re-enslavement in Twenty-fifth Corps. The

${ }^{239}$ Ibid. 
mutiny of the Twelfth USCHA also shows that USCTs viewed injustices through the lens of American society and its racial codes, as well as through their entire experience in the service. Coyl neglected to consider why the mutineers might have felt that they lacked a legal avenue to redress their grievances. However, the general's futuristic quote reveals that he envisioned a more racially egalitarian U.S. military. While not a full white ally, he expected and indirectly endorsed an advance in the long emancipation, even if he considered it successful enough to the point that mutiny was never justified for African-American soldiers. Therefore, Coyd occupied a middle ground between white ally and enemy of the emancipation process.

The story of the Twelfth USCHA's mutiny underwent another twist when the Army invalidated the case on a technicality, prompting a second trial of the convicted group of mutineers. In November 1865, this time around, the Army ruled Beach and Williams innocent, while Thornton, Lisle, Roe, and Woodson received sentences of four to six years of hard labor at Dry Tortugas. Thus, the defense's decision to repeat the strategy from the first trial paid dividends. Meanwhile, the evidence was damning enough for Carter and Wormley to once again face capital punishment. However, their sentences were later commuted to ten years of hard labor. In the second trial's testimony, Captain Hulanski and other officers recognized Carter as a participant more surely than the other defendants. Hulanski alone identified Wormley. Also, the outfits of Carter and Wormley matched the ones found at the scene of the crime. Regardless of guilt, by June or July 1866, all those convicted were released. ${ }^{240}$

The decision by the supposed former members of the Seventy-second Ohio Colored Infantry to mutiny in the late summer of 1865 can be contextualized in the broader nineteenthcentury experience of African Americans in the North, the middle border region, and Ohio.

\footnotetext{
${ }^{240}$ Proceedings of GCM, Trial of James Thornton, et. al., MM-3329, RG 153, NARA.
} 
Living on the border between the free North and slave South, these men grew up in a free, but impoverished, black labor system, as well as in the specter of slave catchers. Though legally free since the passage of the 1787 Northwest Ordinance, black Ohioans lived under "black laws" that deprived them of numerous citizenship rights, such as suffrage, jury duty, education, and militia service. Black hostility to second-class citizenship and violent white racism led to riots and a relocation of African-American Cincinnatians to Canada in the 1820s and 1830s. Moreover, given Ohio's border with two slave states, those in the Seventy-second lived in a popular destination for those crossing through the Underground Railroad as well as the heart of the heated debates over fugitive slave laws. They resided in a section and state which saw black activists combat racism during the antebellum years by joining the abolitionist movement; advocating the repeal of the black laws, which had partial success in 1849; and forming protest organizations, newspapers, schools, and benevolent institutions. They thereby attracted a small number of white allies who rejected gradualism in favor of immediate abolition. ${ }^{241}$

From the start of the war, northern African Americans, both free-born men and refugees from southern slavery, along with their white abolitionist allies, demanded to serve in the Union Army. They hoped to use the conflict as an opportunity to emancipate their southern brethren and to make a claim for full racial equality for free blacks. Once northern states finally started recruiting black regiments, the members of the Seventy-second Ohio would have shared the frustration of expecting equal pay but receiving unequal pay for much of the war. They also had

\footnotetext{
${ }^{241}$ Ira Berlin, The Long Emancipation: The Demise of Slavery in the United States (Cambridge and London: Harvard University Press, 2015), 78-79, 145-146; James Bissland, Blood, Tears, and Glory, 320; Richard S. Newman, The Transformation of American Abolitionism: Fighting Slavery in the Early Republic (Chapel Hill: University of North Carolina Press, 2002); W. Sherman Jackson, "Emancipation, Negrophobia and Civil War Politics in Ohio, 1863-1865," The Journal of Negro History, Vol. 65, No. 3 (Summer, 1980), pp. 250-260; J. Reuben Sheeler, "The Struggle of the Negro in Ohio for Freedom," The Journal of Negro History, Vol. 31, No. 2 (Apr., 1946), pp. 208-226; Stephen Middleton, "The Fugitive Slave Crisis in Cincinnati, 1850-1860: Resistance, Enforcement, and Black, Refugees," The Journal of Negro History, Vol. 72, No. 1/2 (Winter - Spring, 1987), pp. 2032.
} 
enlisted in a state with a Copperhead stronghold that appealed to white Ohioan fears that an exodus of freed slaves from neighboring Kentucky and Virginia would overrun the state. However, other white Ohioans championed black enlistment. For these northern mutineers, the harsh discipline that reminded southern blacks of slavery would have been the latest of many examples of racial resentment that at times sparked black resistance. While free black northerners did not face the level of subjugation seen south of the Ohio River, they were just as committed to the completion of the long emancipation. Regardless of section, blacks who avoided becoming or re-becoming human property prior to the Civil War knew that they needed to wage additional struggles for black freedom after their or their ancestors' enslavement ended.

Furthermore, not just southern black troops with families in contraband camps, but also black northern soldiers desired a return to civilian life once they helped defeat the Confederacy. In July 1865, Private Richard McDaniel of the Eleventh USCHA, an Indianan, did not mutiny, but offered an account of conditions in the immediate postbellum era that give us an insight into a perspective of northern black men that drove some of them to mutiny. McDaniel traced his experiences with racism since the start of the war. In 1861, whites blocked his attempt to answer Lincoln's call for troops to crush the rebellion, blamed African Americans for starting the conflict, and issued dire warnings of the consequences of black enlistment. He began to lose hope of ever enlisting. In the fall of 1863, Rhode Island recruiters arrived, at which point he enlisted in the Eleventh USCHA. After serving for almost two years, McDaniel wondered about whether black soldiers received honor after proving themselves as high-quality soldiers. He discussed white plans to prevent the northern states from living with black veterans now that the Union had been saved. He expressed hope that whites would never avoid "the negro question." Eventually, McDaniel asserted, white officers begged black northerners and southerners to enlist 
in the Union Army, not to free them, but to help win the war. To support this claim, he cited the lack of white officer support for black enfranchisement. Now that whites had won the war and saved the Union with black assistance, they no longer cared for, or had interest in living with, their former comrades. McDaniel emphasized the need for black men to resist this situation in order to promote the rights of education and suffrage. As this private shows, many AfricanAmerican servicemen felt that white northerners had abandoned them once the Civil War ended. Unjust punishment in the Army would have exacerbated these bitter sentiments. ${ }^{242}$

Occupying the northern theater of the long emancipation, the men of the Seventy-second USCI/Twelfth USCHA used mutiny to continue the struggle for black freedom into the immediate postbellum period. They joined those black civilians in Ohio during the Civil War era who successfully fought for enfranchisement using activism. As Christopher Phillips has recently uncovered, during the antebellum era, Ohio's political culture, based on white supremacist centrism, matched the other free states (Indiana and Illinois) as well as slave states (Missouri and Kentucky) of the middle border region. However, civil war and emancipation brought the free border states politically closer to the rest of the North. They supported Republican Reconstruction efforts during the 1860s, separating them from the former slave border states, which like the ex-Confederate states, embraced the Lost Cause and saw similar types of racial violence. In the months following the Union's victory, a group of black Ohioans could not be certain that the emancipationist legacy would fully take hold, driving them to desperation. ${ }^{243}$

\footnotetext{
${ }^{242}$ Letter from Richard McDaniel, Co. G, $11^{\text {th }}$ USCHA, Donaldsonville, Louisiana, June 25, 1865, Weekly AngloAfrican, July 26, 1865, Edwin S. Redkey, ed., A Grand Army of Black Men: Letters from African-American Soldiers in the Union Army, 1861-1865 (Cambridge: Cambridge University Press, 1993), 265-268. For those black northerners possessing job skills, mustering out would allow them to resume the careers they had paused. See A Loyal Citizen \& Friend to all to Hon. Edward M. Stanton, July 1865, A-278 1865, Letters Received, ser. 360, Colored Troops Division, RG 94 [B-192], in Ira Berlin, The Black Military Experience, 772-773.

${ }^{243}$ Christopher Phillips, The Rivers Ran Backward: The Civil War and the Remaking of the American Middle Border (New York: Oxford University Press, 2016). See also Robert D. Sawrey, Dubious Victory: The Reconstruction Debate in Ohio (Lexington: University Press of Kentucky, 2015); Anne E. Marshall, Creating a Confederate
} 
The acts of defiance by USCTs during the Civil War and in the immediate postwar months, and their criticism of those black soldiers who chose not to mutiny, grew out of early republican discourses on freedom, slavery, and resistance. The articulation of rights during the Civil War and Reconstruction followed decades of Americans disagreeing over what freedom meant. While abolitionists invoked the universal notion of rights contained in the Declaration of Independence, others used revolutionary rhetoric to preserve and justify slavery. Francois Furstenberg examines how revolutionary and post-revolutionary America drew on "liberal, republican, religious traditions to define freedom as autonomy, or the capacity for human agency — that is, individuals' ability to act in secular time and shape their circumstances." The American Revolution constituted a people's heroic act of resistance against enslavement. According to Thomas Paine, enslavement requires humans to surrender and consent to it. While white Americans proved their worth for freedom by courageously waging the Revolution, enslaved African Americans deserved to remain in bondage because they cowardly chose not to fight and die for freedom. Only when an enslaved man broke his chains of bondage with violence or died doing so could he be worthy of freedom. Traditional white racial ideology painted enslaved black men as unvirtuous, dependent, feminine, and unwilling to resist, making them unfit for freedom. Whiteness represented virtue and liberty; blackness signified degradation and slavery. Forms of day-to-day, nonviolent resistance confirmed the stereotype of the lazy, deceitful slave who lacked virtue because proslavery ideology denied that such acts constituted true resistance. Proslavery ideology also disagreed that running away and rebellion was actual resistance because it attributed such actions to outside inspiration or as examples of disease; slaves inherently lacked agency and virtue. Meanwhile, abolitionists portrayed slave revolts such 
as the Haitian Revolution as righteous struggles for freedom. The infamous rebellion proved that those of African descent were capable of self-government through demonstrations of martial masculinity and virtue. Radical abolitionists of the antebellum era called on African Americans to act for themselves, viewing death in a revolt as preferable to being human property. Different ideas of freedom, who can be free, and how they can attain it, all competed with each other. ${ }^{244}$

Just as white Americans during the Revolution, early republic, and antebellum era invoked African slavery when discussing the need to resist government oppression and thought freedom was something they deserved through struggle, USCTs thought freed African Americans in the Union ranks should resist officer mistreatment to earn their newly won emancipation. Also, by living under a dominant culture that denied them manhood because they did not resist white oppression, mutineers sought to prove their masculinity by aggressively combating military racism, especially when such bigotry worsened in the summer of 1865 . In fighting for their liberty after the collapse of slavery, immediate postwar mutineers wanted to follow the example of rebellious slaves and wartime black Union soldiers. When they noticed that most comrades seemed to accept white oppression through inaction, they considered them unmanly, cowardly, and undeserving of freedom. Early postbellum USCT mutinies represent the continuation of the republican, revolutionary ideology of resistance at a key moment in time.

Mutineers' harsh words for comrades who passively accepted Army life in the summer of 1865 compare with Frederick Douglass' argument that black men needed to fight for their freedom to attain recognition for this freedom. While Douglass' ideology applied to bondsmen and black soldiers at war with slaveholders, the USCT mutineers in Virginia, Kentucky, Texas, and elsewhere transferred this manly struggle to black troops facing continued racism in the

\footnotetext{
${ }^{244}$ Francois Furstenberg, "Beyond Freedom and Slavery: Autonomy, Virtue, and Resistance in Early American Political Discourse," Journal of American History 89, no. 4 (March 2003): 1295-1330 (quote on 1296).
} 
postbellum Army. If they refused to resist excessive punishments for trivial offenses, they in effect consented to it and thereby encouraged their white officers to continue to abuse them. Their cowardice called into question the manhood they had proven through their military service. Also, mutineers' experiences being bucked, tied up, and confined in a closed space under guard adds credence to Carole Emberton's point that egregious forms of violence and coercion accompanied emancipation. Moreover, in telling officials that they could not provide for their families while in Texas or in prison, mutineers invoked the republican ideal of a man protecting his dependents and the white northern cultural connection between family and military service. That mutineers in numerous units levied this charge on non-resisters illustrates a widespread adherence to martial masculinity in the USCT ranks. However, as Emberton also notes, this type of manhood pushed soldiers to commit actions that threatened their lives, livelihoods, family welfare, and finances. The price of being so dedicated to martial masculinity consisted of imprisonment, hard labor, dishonorable discharge, and/or execution. ${ }^{245}$

When a black mutineer refused an order to properly clean an item, conducted a tirade against white oppression and black cowardice, and/or tried to liberate an imprisoned comrade by force, he created a moment in which one can examine the tides of nineteenth-century American thought and the development of race relations in the Union Army's final stage. During his mutiny, martial manhood struck against more passive forms of masculinity and more restrictive models of citizenship. In his own personal revolt, an African-American man made a claim to the same republican virtue that justified the American and Haitian Revolutions. He also laid out some of the terms for how American emancipation should unfold in Reconstruction now that he had helped topple a slaveholder's republic. The early postbellum mutineer ultimately captures

\footnotetext{
${ }^{245}$ Carole Emberton, "Only Murder Makes Men": Reconsidering the Black Military Experience," The Journal of the Civil War Era, Volume 2, Number 3 (September 2012): 369-393.
} 
the contradictions and contingencies of nineteenth-century America. When the long-simmering tensions within a unit boiled over, the resulting mutiny had motivations broader than their own localized circumstances. It tied in the legacy of slave resistance, the Union Army's race relations, and the promises of the dawning post-abolition era. Mutineers used a common metaphorical and literal language of whites physically controlling black behavior, as suggested by the verbs “imposed upon” and "run over.” A black soldier's life featuring any combination of slavery, kidnapping, impressment, conscription, or discrimination made these actions by white officers repulsive, especially at this crucial moment in the emancipation process. African-American troops grew weary of their bodies being forcibly relocated, struck, and trampled on at every step of their liberation thus far. Entrenched notions of martial masculinity led to the desire to confront the newest obstacles to their ability to enjoy any of the pillars of their envisioned emancipation: bodily autonomy, family security, and socioeconomic independence.

Though the numerous mutinies immediately following the Civil War ultimately failed to end the U.S. Army's neglect of black soldiers' families and its severe disciplinary practices, they foreshadowed postbellum black political struggles through which freedpeople also tried to secure the freedom from white mistreatment and the right to exert control over their own lives. Acts such as black soldier revolts signified that African Americans in the post-emancipation era would fight to eliminate what they perceived to be vestiges of slavery and to finally enact racial equality. Among these vestiges were ex-Confederates committed to suppressing black political activity and reestablishing white supremacy, often by attacking black soldiers and lobbying for their removal. The presence of occupying black federals in the defeated Confederacy symbolized freedpeople's newly won freedom and their hopes for the post-emancipation future. They also represented white southern fears of emancipation's threat to society and their humiliating defeat 
in the war. As Chad Williams shows, ex-slaveholders erroneously believed black troops would incite the Christmas Insurrection of 1865. Numerous instances occurred in which white southern paramilitaries beat, shot, and yelled racial epithets at black soldiers. Despite bondage's death, armed blacks still conjured up the frightening image of a slave rebellion. ${ }^{246}$

Against this fierce white opposition, after leaving the U.S. military, freedpeople struggled to secure political, social, economic, and cultural freedoms. Against fierce white opposition black southerners formed conventions and meetings demanding the right to vote. These efforts culminated with the ratification of the Fourteenth and Fifteenth Amendments in 1868 and 1870, respectively. Prior to this, white paramilitary groups like the Ku Klux Klan, the White League, the Red Shirts, and the Regulators brutally attacked African Americans and symbols of black autonomy in locations throughout the South. With suffrage, black men formed Republican Party voting blocs in local, state, and national elections. Pursuing other forms of autonomy, ex-slaves spent the postbellum period building their own independent churches and pursuing favorable work arrangements. During a postwar labor shortage, freedpeople signed contracts, which they had not been permitted to do as slaves, symbolizing their new freedom. To earn better wages, many alternated between employers. Such mobility symbolized a departure from masters prohibiting slaves from leaving the plantation and from officers requiring black troops to remain in the postwar Army against their will. In urban areas like Baltimore, black longshore laborers unionized to increase their wages while invoking the golden opportunity facing African Americans after the war: "Since the breath of political life had been breathed into the colored man, manhood had asserted itself, and American civilization made the colored man like all other

\footnotetext{
${ }^{246}$ Chad Williams, "Symbols of Freedom and Defeat: African American Soldiers, White Southerners, and the Christmas Insurrection Scare of 1865," in Black Flag Over Dixie: Racial Atrocities and Reprisals in the Civil War, eds., Gregory J. W. Urwin (Carbondale, IL: Southern Illinois University Press, 2005), 210-230; Joseph Glatthaar, Forged in Battle, 212-218.
} 
men." After serving in the Union Army and in politics, black men now wanted to be "sufficiently paid for their labor." In a successor to USCT mutineers berating comrades for not resisting as well, cases exist of black strikers throwing stones at co-workers who refused to join their work stoppage. When whites threatened to commit violence against blacks intending to vote in $1870 \mathrm{~s}$ elections, and targeted free black agricultural laborers in the late 1860s, African Americans fought back. In various cities and rural areas, they came armed and prepared to once again struggle for their people's rights to act as they saw fit and live independently without the threat of white abuse and control, just as USCT mutineers did. Since black Union veterans could purchase their weapons from the Army when mustering out, they used the same arms that defeated the Confederacy to resist ex-Rebels in paramilitary combat and to boast of their newlywon manhood. In this way, the tradition of free black armed self-defense through antebellum black militia formation had postbellum successors. ${ }^{247}$ For the rest of the nineteenth century and into the twentieth, African-American servicemen and civilians needed to fight their struggle for freedom against the twin threats of white civilian hostility and U.S. military mistreatment.

The black mutineers in the early postbellum U.S. Army did more than just rise up against their officers' decisions to send them far away from their families, strictly regulate their lives, and tie up comrades by the thumbs. Having escaped slavery in various ways, and having played their part in defeating the Confederacy, these individuals thought that another chapter in their struggle for black freedom and fair treatment was necessary. They needed to once again assert their right to act independently before they could return to civilian life and finish implementing

\footnotetext{
${ }^{247}$ Aaron Astor, Rebels on the Border: Civil War, Emancipation, and the Reconstruction of Kentucky and Missouri. (Baton Rouge: Louisiana State University Press, 2012), 168-242; Howard, Black Liberation in Kentucky, 91-107, 146-159; Donald Robert Shaffer, After the Glory: The Struggles of Black Civil War Veterans (Lawrence: University Press of Kansas, 2004), 31; "Local Matters: Mass Meeting of Longshore Laborers," September 21, 1871, Baltimore Sun, George DuBois Collection of Maryland Labor History, University of Maryland Archives, College Park, Maryland (quotes); “Strike for Higher Wages at the Chesapeake Company's Gasometer Pit," June 8, 1886, Ibid.
} 
Reconstruction. By mutinying, they hoped to secure an existence without white abuse and white control over their lives, a life they thought they had gained through their exit from slavery and through military service in defense of the Union. In defying white power, the mutineers can be placed at a key junction on the continuum of emancipation stretching from prewar slave and free black resistance to the mass black exodus to Union lines and to postwar African-American political activity. However, as Reconstruction progressed and as the U.S. Army built a new postbellum regular army with African-American units, black men in the ranks persisted in their mutinous behavior. Racial tensions leading to defiant and violent behavior would continue to characterize the black soldier experience in the country's different regions well into the late nineteenth century. When black troops stopped revolting against the Army's policies for shifting to a peacetime force, they still found mutiny necessary when they tackled the broader sociopolitical struggles accompanying the South's readmission to the Union and the country's imperial project in the West. 


\section{Chapter 4}

\section{"I don't care a damn for you, you take the advantage of me because I am a colored man":}

Black Soldier Mutinies and Race Riots in the Reconstruction South

In the spring and summer of 1866, Private Adam Johnson, a twenty-six-year-old coachman in the South Carolina-based 128th U.S. Colored Infantry (USCI), joined comrades in bloody rebellions against two sources of white supremacy. First, in May of that year in Charleston, he and seven others violently defended themselves against one of the many white civilians hostile to the presence of occupying black troops in the conquered South. The citizen, William Rollins, drew a firearm on them because they walked too close to his farm. He threatened that unless they avoided taking another step, "you damned black son of a bitch...I'll blow your brains out." During the incident, Johnsons' corporal expressed a willingness to "blow" Rollins' "brains out" and Johnson himself joined a bayonet charge against him. Later that July, while stationed on Folly Island, Private Johnson helped launch a mutiny on behalf of a comrade arrested and tied up for attending a dance with black women. Following the orders of another noncommissioned officer to "go up and cut him down" or else "they were no men," Johnson and a group of comrades exchanged fire with white commissioned officers who eventually restored order. While sitting in prison for the second revolt, Johnson won a remittance after writing a letter to the high command in which he cited the suffering of dependent family members. The numerous decisions of Johnson and other black soldiers, especially to confront any antagonistic white man, military or civilian, helped form the basis of the next phase of the long emancipation struggle. For participating in two incidents while a member of a regiment that frequently rose up, Adam Johnson constituted the most mutinous member of the most mutinous regiment. That Private Johnson questioned the worthiness of non-mutineers for manly citizenship; resisted white regulations of blacks' bodily autonomy, including their right to engage in leisure; and invoked 
family welfare to minimize the consequences of his rebelliousness demonstrates that the AfricanAmerican vision for a complete liberation remained paramount as men like Johnson tried to shape the course of the country's Reconstruction. ${ }^{248}$

The black mutinies of the Reconstruction period occurred in part to influence the federal government as it tried to bring the conquered South back into the Union and determine the status of freed slaves. An outgrowth of the military effort that defeated the Confederacy, the federal government used an occupying army to implement the Reconstruction project. Since African Americans enlisted later in the war than white soldiers, black units formed a disproportionate share of the early Reconstruction-era occupation force. The USCTs and other federal occupation forces faced the task of helping freedpeople in the South move from bondage and war to freedom and peace, all while confronting a hostile civilian population determined to restore white supremacy. Since African Americans wanted to enjoy the freedom that came with Union victory and were determined to defend their rights during Reconstruction America's citizenship debates, troops occupying the former Confederacy continued the African-American tradition of overt resistance. The racial tensions that characterized much of Reconstruction's duties prolonged the postbellum epidemic of ill-discipline and mutiny in the USCT ranks.

As the country moved deeper into the postbellum era, African-American servicemen confronted a variety of threats to their full emancipation. Across Reconstruction America, black

\footnotetext{
${ }^{248}$ Proceedings of a General Court-martial, Trials of Adam Johnson, John Nix, John Simmons, Samuel Bailey, William Darrill, William Boyd, Thomas Sastry, and Milton Ford, OO-1686, Trials of William Frederic and Joseph Mitchell, OO-1796, Trials of Thomas Trowell and Laddres White, Folder 1, Trials of Adam Johnson and Joseph Pine, Folder 2, Trials of Frank Frazier and Nelson Hicks, Folder 3, OO-3733, RG 153, NARA; Civil War Pension Record for Thomas Trowell now known as Frank Gadison, SC No. C2.476.756, Private, Company G, $128^{\text {th }}$ USCI, Records of the VA, RG 15, NARA, quoted in John Gourdin, Borrowed Identity: $128^{\text {th }}$ United States Colored Troops (Westminster, Maryland: Heritage Book, 2009), 47-48; Adam Johnson Service Record, NARA, www.fold3.com. It is less apparent in the service records of the $128^{\text {th }}$ 's mutineers whether they were previously enslaved or born free. During the resulting court-martial, those of the Rollins household painted the incident as an unprovoked attack by the troops followed by William's armed self-defense.
} 
troops revolted not only against despised white officers who threatened the progress of their emancipation, but also against a prejudiced white society that assumed this role as well. When they mutinied against the military, it was often when white officers or enlisted men appeared aligned with white civilians in opposing black civil rights. What differentiated the South's immediate postbellum mutinies from Reconstruction-affiliated ones was that the latter's participants tended to have social rather than military causes. Black soldiers rose up against perceived injustices associated not with remaining in uniform after the war, but with issues confronting those of their race in the long-term; they endorsed staying in the Army in order to improve the political and social standing of black Americans. Further, black soldiers occasionally joined civilian freedpeople in clashes with hostile whites, helping AfricanAmerican society conduct civil rights struggles. The root cause of these conditions was what Reconstruction-era black soldiers symbolized: inspiration for newly-freed blacks and bitterness for humiliated whites. This status shaped and bred the conditions out of which some troops chose to mutiny. ${ }^{249}$

Soldiers stationed in the Reconstruction South assumed law enforcement duties and contended with antagonistic civilians, resulting in revolts against oppressive civilian authorities. Since these duties placed black troops as guards in southern jails, these sites tended to be among the breeding grounds of mutinous behavior in the Reconstruction era. Just as mutinies against officers upended the military hierarchy, this type of occupation service levelled the South's traditional social hierarchy. Essentially, black resistance to white supremacy, whatever its form, centered on overturning or altering power relations. Uniformed African Americans tasked with maintaining civil order, on which antebellum whites had a monopoly, so upended southern

\footnotetext{
${ }^{249}$ Ira Berlin, Freedom: A Documentary History of Emancipation 1861-1867: Series II: The Black Military Experience (Cambridge, Cambridge University Press, 1982), 737.
} 
power structures that counter-revolutionary whites frequently targeted them. The need to continue implementing the long emancipation required black soldiers to resist such attacks.

Most of the scholarship on Reconstruction-era African-American resistance to white supremacy focuses on social and political history. After slavery, work remained to determine the meaning of freedom and the proper course with which to clinch it. When beginning their new lives, ex-slaves faced the daunting task of ensuring that freedom meant something beyond merely leaving slavery, a status that many feared would not protect them from destitution and exploitation. A common thread throughout this historiography is the central goal of the long emancipation, liberty from white control over their lives, for which black mutineers fought. ${ }^{250}$

The need of freedpeople to give substance to their freedom necessitated collective, direct action. Just as black soldiers rebelled against their white authorities to advance their understanding of citizenship, those in the civilian black working class, upon moving from a slave society to one based on wage labor, engaged in unrest to demand concrete improvements in their autonomy and well-being from their white employers. They also sought to end the practice whereby most white labor unions excluded blacks from membership, prompting them to create new, more inclusive bodies.

This wave of organization especially hit the Baltimore-Washington, D.C., area, where labor militants often cited martial masculinity and the emancipationist legacy of the Civil War. From 1865 to 1883, African-American caulkers in Baltimore operated the Chesapeake Marine Railway and Dry Dock Company, a cooperative workshop. Another sign that African Americans desired collective action on the socioeconomic front was Washington, D.C.'s Colored National Labor Convention of December 6-10, 1869. Over two hundred mechanics, artisans, and other

\footnotetext{
${ }^{250}$ James Greenly Diary, May 9, 1865, Southern Historical Collection, UNC Chapel Hill; Eric Foner, Nothing But Freedom: Emancipation and Its Legacy (Baton Rouge: Louisiana State University Press, 1983).
} 
skilled workers attended. In an address to the body, Rhode Islander George Downing noted how "the colored, as well as the white laborers of the United States, are not satisfied as to the estimate that is placed on their labor." The Republican Party, Downing continued, deserved credit and support for "liberating us from unrequited toil." However, there was more to be desired from the GOP, which should have fed and sheltered blacks while they still endured bondage. Looking ahead to the upcoming ratification of the Fifteenth Amendment, Downing advised that in the interest of its durability, the party needed to recognize the working class' intelligence, legislative needs, and unity. Drawing from slavery and the country's revolutionary ideals, the speaker noted that "the colored man's struggle until now has been for naked existence, for the right to life and liberty." The Fifteenth Amendment's ratification and black participation in the labor movement would enable African Americans to seek the next right, "the pursuit of happiness." According to Downing, all workers shared the same interests, necessitating interracial collaboration. These lines reflected African-American calls for a biracial labor movement before the convention. The convention endorsed the creation of black-owned cooperatives and gave birth to the Colored National Labor Union (CNLU), which named Isaac Myers, a member of Baltimore's black caulker cooperative, as its president. By the 1870s and 1880s, however, the egalitarian Knights of Labor became the dominant national labor body for black workers. ${ }^{251}$

Meanwhile, Baltimore's black workers continued to organize at a local level into the 1870s. A Colored Mechanics' and Laborers' Association formed in 1870. The following year, black longshore laborers met to propose forming a body tasked with increasing their wages and fostering harmony in the city's working class. They invoked their manhood and Union military

\footnotetext{
251 "Proceedings of the Colored National Labor Convention held in Washington, D.C., on December 6th, 7th, 8th, 9th, and 10th, 1869," WVU Downtown Library microfilm, Morgantown WV; Earl Ofari, "Black Activists and $19^{\text {th }}$ Century Radicalism,” The Black Scholar, Vol. 5, No. 5, Black Economics (II) (February 1974), pp. 19-25.
} 
service: "Since the breath of political life had been breathed into the colored man, manhood had asserted itself, and American civilization made the colored man like all other men." After serving in the military and in politics, black men now wanted to be "sufficiently paid for their labor." In October 1875, a biracial oyster shucker procession celebrated a labor settlement with packers, during which they exhibited racial solidarity and the police confronted them. Black and white oyster shuckers delayed resuming work until the finalization of their agreement, which came several days later. Towards the end of the Reconstruction era, members of a workingmen's meeting recommended that the local Workingmen's Party court black voters, linked the cause of the labor movement with the war's emancipationist legacy, and revealed that African Americans desired to join the party; others disagreed due to the party's racism and the history of blacks as a GOP voting bloc. The Workingmen's Party, however, struggled to win black votes in municipal elections. As African Americans entered the post-slavery American economy, they knew that the key to maximizing their socioeconomic independence was using their strength in numbers. ${ }^{252}$

From these efforts at black labor organization, one can identify a recognition that the black freedom struggle moved to a new phase after the death of slavery, one looking ahead to a biracial political and economic democracy and backward to the Civil War. This movement towards collective action among African-American workers as a means of acquiring this biracial democracy crossed over into the U.S. Army as well. The weapons and organization structures that gave the first black soldiers unprecedented power during the crusade to destroy slavery became important once more as they determined what a post-bondage era should look like.

The post-Civil War wave of black labor activism owed its existence to predecessors. Slaves had always disrupted their workplaces in order to improve their condition, and free

${ }^{252}$ Baltimore Sun, October 2, 1869, February 8, 1870, September 21, 1871, January 20, 1872, October 4-5, 7-8, 12, 1875, August 24, 1877, October 25, 1877, University of Maryland, College Park, MD. 
African-American workers participated in the prewar labor movement. Building off of both, black Civil War soldiers conducted a new struggle for equal and adequate pay and safer working conditions. Ex-slaves, black Civil War veterans, those experienced with earlier black labor activism, and the descendants of all three overlapping groups converted this preexisting energy into a robust struggle for the economic aspect of the envisioned biracial democracy that influenced American society during the rest of the nineteenth century.

A common theme in Reconstruction scholarship centers on how the black family changed after slavery's death. Emancipation allowed blacks to live with kin without the threat of a loved one being sold. Whereas slave marriages lacked any legal status, freedom meant that blacks could legally form marital unions. As Noralee Frankel reveals, emancipation transferred authority over the black family from masters to male African-American household heads and gave the black family new economic roles like care for the elderly and hiring children out. It was this role that drove African-American soldiers throughout the Civil War and Reconstruction era to rise up in defense of their dependents' welfare. ${ }^{253}$

Political historians show that African Americans shaped the terms of their emancipation following the Civil War through activism and voting. Emancipation transformed black southerners into a powerful electoral political force for three decades. They shifted from human property existing outside of formal politics to voters and officeholders in each level of government. Steven Hahn has demonstrated that in doing so, freedpeople built on political resistance and networks they formed under slavery. After the Union triumphed and the peculiar institution collapsed, blacks registered to vote, participated in state constitutional conventions, and demanded passage of the Reconstruction Amendments. During Radical Reconstruction,

\footnotetext{
${ }^{253}$ Noralee Frankel, Freedom's Women.
} 
freedpeople politically mobilized by establishing clubs, joining Union Leagues, electing Republicans, conducting rallies, and uniting to protect themselves from white supremacist violence. Freedpeople thereby revolutionized a southern electoral system previously dominated by white slaveholders. Even after Redemption, African Americans remained an electoral force in certain areas of the South. During the 1870 s and 1880s, they formed biracial electoral alliances in the Readjuster and Populist movements. By the turn of the century, however, Jim Crow segregation and disenfranchisement severely weakened this southern black electoral influence. ${ }^{254}$ Occupying the intersection of social and political history, some historians of Reconstruction note that partisan organizations could function as labor unions and vice versa; collective action blurred these boundaries. James Illingworth documents this aspect of Reconstruction in the urban and commercial South, examining how the black working class in cities like New Orleans did not just form an identity as wage earners but also constituted the base of Louisiana's Radical state government. Urban slavery's practice of hiring out bondspeople gave the Crescent City's blacks greater autonomy than what rural slaves enjoyed, allowing the former to develop a politically engaged community following slavery. After fueling the Union war effort, urban black worker militancy helped overthrow Presidential Reconstruction and advance the Radical form of Reconstruction in Louisiana through voting, office-holding, and paramilitary combat. From the mid-1860s to the early 1870s, New Orleans' African-American longshoremen, who worked in the commercial heart of the city, organized, marched, and struck against low wages and contract labor. Illingworth emphasizes how this black-led revolutionary tide gave freedpeople confidence and a sense of control over their destiny. As Illingworth shows, however, elite Republicans condemned striking black waterfront workers for violating

\footnotetext{
${ }^{254}$ Steven Hahn, A Nation under Our Feet: Black Political Struggles in the Rural South from Slavery to the Great Migration (Cambridge: Harvard University Press, 2003), quote on p. 15.
} 
strikebreakers' right to work, infringing on private property, and expecting upward mobility through government support rather than self-reliance. Due to this labor unrest, the Republican white elite began siding with employers against the black rank-and-file, quelling a series of strikes in the early 1870 s. This shift paved the way for the northern retreat from Reconstruction and toward southern Redemption. ${ }^{255}$

The radicalization of the Reconstruction-era southern black working class mirrors that of black mutineers, who also chose drastic actions to defend their rights. It was not enough to just become a civilian worker or military serviceman who earned wages with which a black man could support his family. Bread-winning arrangements could still entail insufficient compensation, exploitation, and white domination of black bodies, despite being less so than under bondage. Just as freedpeople at large clashed with northern and southern civilian whites, over the structure and nature of post-slavery life, black federal troops also struggled with white military leadership and civil law enforcement over the same issue during Reconstruction. For emancipation to mean anything, African-American laborers in the civilian economy and in the armed forces disrupted the regular course of their company or unit's operations as a means of compelling their white employers to agree to alleviate or end injustices.

The ways in which the white press used black soldier mutinies after the war to foment hostility to the Reconstruction chapter of the black freedom struggle compared with the messages it circulated about postbellum black labor unrest. In June 1871, black workers employed on public works projects in Washington, D.C., struck for a \$2.00 daily wage, which

\footnotetext{
${ }^{255}$ James Illingworth, "Crescent City Radicals: Black Working People and the Civil War Era in New Orleans," PhD Dissertation, UC Santa Cruz, 2015, quote on 263, https://escholarship.org/uc/item/1g4548w5. For other works of black labor radicalism in the urban South during the Reconstruction years, see David S. Cecelski, The Waterman's Song: Slavery and Freedom in Maritime North Carolina (Chapel Hill and London: University of North Carolina Press, 2001); Peter Rachleff, Black Labor in Richmond, 1865-1890 (Urbana and Chicago: University of Illinois Press, 1989); Michael W. Fitzgerald, Urban Emancipation: Popular Politics in Reconstruction Mobile 1860-1890 (Baton Rouge: Louisiana State University Press, 2002).
} 
their white counterparts earned, instead of the current \$1.25. The Hillsdale Standard of Michigan described these "negro laboring men" as "ignorant and inflamed...rioters." Moreover, according to the paper, these strikers received rhetorical assistance from "some of the lowest negro demagogues," who "made incendiary speeches," by which the paper meant pro-labor, black Republican activists. The local D.C. press, such as the Evening Star, deemed the language of the strike leaders as "bloodthirsty" and comparable to the words uttered in the Paris Commune. Black mutineers, strikers, insurrectionists - all symbolized what white supremacists identified as the disastrous nature of a post-emancipation society. What represented bloody anarchy to the opponents of emancipation was to its defenders a necessary fight to attain human rights. ${ }^{256}$

In a postbellum version of black resistance to unfree labor, the Reconstruction period furthermore witnessed African-American convicts rise up. The long emancipation entailed not just a struggle against perceived injustices in postbellum southern society and in the U.S. military, but also against the convict leasing system. After becoming part of an unfree labor system which scholars call "neo-slavery," one based on the prosecution of bogus or inflated charges, African Americans became desperate to improve their lives. Without legal means of redress to do so, they rebelled against the authority of their white overlords. ${ }^{257}$

Three examples of neo-slave resistance from 1875 resembled other forms of black rebellion. In Hagerstown, Maryland, one black prisoner, Justin Shipley, revolted against prison authorities in February 1875. Prison authorities shot the man three times, producing non-fatal injuries and forcing him to surrender. In March 1875, Richmond prison officials found the

\footnotetext{
256 "From Washington," Hillsdale Standard, June 20, 1871, https://access.newspaperarchive.com/; Robert Harrison, Washington during Civil War and Reconstruction: Race and Radicalism (Cambridge: Cambridge University Press, 2011), 286. With the government failing to negotiate a deal, police and military forces quelled the strike.

${ }^{257}$ For works on violations of the Thirteenth Amendment in the postbellum South, see David M. Oshinsky, Worse than Slavery: Parchman Farm and the Ordeal of Jim Crow Justice (New York: Free Press, 1997); Douglas A. Blackmon, Slavery by Another Name: The Re-Enslavement of Black Americans from the Civil War to World War II (New York: Anchor, 2009).
} 
twenty-seven African-American members of the chain gang they commanded "in a state of mutiny." The black prisoners refused the officers' orders to begin working. Meanwhile, the white convicts complied. When the officials inquired into the reason for this unruly behavior, ringleaders Samuel Robinson, Richard Banks, and Caesar Seaton cited insufficient food; they had decided against working until this issue was resolved. According to a white official, the three ringleaders pressured other prisoners into participating in the work stoppage and, in contrast to the ringleaders' story, black prisoners already received the same amount of food as their white counterparts. When the captain proceeded to send all strikers to a dungeon, as a press account put it, "the conspiracy was soon dissolved." November 1875 saw three black and two white convict workers, who labored in a Pittsburgh whip factory of ninety employees, corner and attack Charles Weaver, their contractor, with hatchets and iron bars. Armed wardens then forced the mutineers to surrender before placing them in dungeons. While it is not clear what motivated all three black prison revolts, the Richmond convicts' desire for better sustenance fits with the broader emancipationist goal of an improved material existence and the forms they took-violent insurrection or work stoppage — match that of free labor strikes, slave revolts, and the mutinies of civilian sailors or military servicemen. ${ }^{258}$

The phenomenon of black soldier mutinies during the Reconstruction era can be seen as yet another example of African Americans becoming more militant, confrontational, and organized when the moment arrived to create a biracial democracy between the mid-1860s and late-1870s. Black labor strikes, free and unfree, disrupted the economy. Meanwhile, black political mobilization shook up the government. Both types of black resistance forced white

\footnotetext{
258 "Revolt in the Penitentiary," Hagerstown Herald and Torch Light, February 3, 1875, https://access.newspaperarchive.com/; "Mutiny of a Portion of the Chain-Gang," Richmond Daily Dispatch, March 9, 1875, Ibid. (quotes); “Convicts Mutiny,” Philadelphia Inquirer, November 17, 1875, Ibid.
} 
superiors to agree to an expansion of African-American civil rights, social power, and economic autonomy. Likewise, black soldier mutinies upset the regular order of military discipline as a means of pursuing similar goals. On the other hand, the coordinated prewar resistance to slavery and the outbreak of mutinies in the early USCTs demonstrate that African-American society and culture already possessed strong networks of resistance going into the Reconstruction era. ${ }^{259}$

The phenomenon of black soldier mutinies adds to the recent scholarly wave emphasizing the militarized nature of Reconstruction. As Gregory Downs contends in After Appomattox, Reconstruction represented a continuation of the Civil War in that it essentially was a military occupation. He reveals that despite the surrender of C.S. forces, the U.S. Army still exercised coercive wartime powers like martial law in the South between the end of the war in 1865 and the seating of Georgia's congressmen in 1871. With President Andrew Johnson hoping for a quick, lenient readmission of the former Confederacy, congressional Republicans needed the Army to carry out their Radical vision of Reconstruction. Military personnel became Reconstruction's de facto political leaders, upholding law and order, approving labor contracts, prosecuting insurgents, overruling civil authorities, interfering in elections, and defending freedpeople's citizenship over the objections of ex-Confederates. The Army deemed its presence necessary to ensure the final destruction of slavery and the establishment of black male suffrage. Ironically, Downs highlights, without undemocratic coercion, the military occupation could not have ensured the creation of a biracial democracy. ${ }^{260}$

Therefore, black troops involved in the occupation of the Reconstruction South recognized that the military type of emancipation was not complete when the country ended the

\footnotetext{
${ }^{259}$ For the most thorough analysis of these long-lasting black networks of resistance, see Steven Hahn, A Nation Under Our Feet.

${ }^{260}$ Gregory P. Downs, After Appomattox: Military Occupation and the Ends of War (Cambridge, Mass.: Harvard University Press, 2015).
} 
full mobilization that waged the Civil War. For some African-American soldiers, a logical extension of helping the U.S. Army carry out Congressional, Radical, and Military

Reconstruction was defending their vision of emancipation in ways that violated military regulations. While the Army's occupation was essential for the emancipation process, its Sable Arm engaged in its own attempts to advance this process forward when white officers and other authorities undermined it. Since Reconstruction's military component intensified paramilitary white supremacist resistance to the project, and since many white northern officers still engaged in strict discipline and opposed full racial equality, some black soldiers waged an independent struggle. The revisionist school of Reconstruction historiography correctly notes that despite the Civil War freeing four million slaves, the aftermath constituted a missed opportunity for black civil rights. For this opportunity to be realized, a number of black servicemen found it necessary to participate in mutinies and race riots while rebuilding southern society in the decade following the Confederacy's defeat.

Because many black soldiers revolted against both officer cruelty and oppression from southern civilians, Reconstruction's military aspect cannot be separated from its social one. Rebellious black troops stationed in the South thus faced a dual threat to their emancipation process. They needed to defend their conceptions of freedom from not just the white northerners of the commissioned officer corps but also the southern white civilians they policed and white civil authorities during a watershed moment of American race relations.

Some former African-American soldiers chose the route of written protests and petitions to further their goals. In March 1866, a former USCT soldier from Maryland informed the Freedmen's Bureau that Confederate veterans frequently attacked black Union veterans and other freedpeople. He pled for protection against these grave threats to their freedom. In July 1867, a 
group of 170 black veterans denounced Kentucky's exemption from the Reconstruction Acts, which deprived them of the right to vote and the resources with which to resist white supremacist violence. Meanwhile, a black veteran in New Orleans documented acts of white supremacist violence against freedpeople who sought an education. Like other eras, Reconstruction advanced the emancipation process forward, but this process nevertheless was relative and incomplete, qualities that made persistent resistance necessary. ${ }^{261}$

Regardless of which path disgruntled African Americans took, they needed to take into account a white culture that advised them against rocking the boat. During the country's debate over the ratification of the Fifteenth Amendment, African Americans learned that a number of whites respected those who passively followed the law rather than rebel against it. In April 1870, a Methodist preacher in Chicago gave a sermon in which he emphasized this message and touched on the goals of the long emancipation. Reverend W. H. Daniels reflected on the progress of black civil rights of the last two and a half centuries: "In the year 1620 the first negro slaves were brought to this country...in this year, 1870, the last restrictions of the rights of the negro as a citizen are removed, and he stands forth a free man and voter." While the experiences of Redemption and Jim Crow eventually disproved this view, such reflections demonstrated that Americans understood emancipation in relation to large stretches of time. Speaking of a parade in honor of the Fifteenth Amendment, the reverend noted that it was fitting that police officers participated because though the legal system had enslaved the marchers, "these people always respected law; they have not been rebellious." Rather than conduct actions like John Brown's raid, to which Daniels referred as a failed "mutiny," blacks "waited patiently for law to deliver them, and for government to adopt them." Since law had previously oppressed them, "how

\footnotetext{
${ }^{261}$ John David Smith, We Ask Only for Even-handed Justice: Black Voices from Reconstruction, 1865-1877 (Amhurst and Boston: University of Massachusetts Press, 2014), 85, 68, 98.
} 
gladly they will obey it when it commands them to be prosperous and free." The preacher continuously praised African Americans for peacefully and patiently waiting for the end of slavery. While this commentary on black passivity ignored the long tradition of overt and subtle black resistance to white supremacy and the key role resistance played in forcing changes in the status quo, it spoke to how blacks needed to contend with white perspectives when they contemplated rebellious actions. ${ }^{262}$ Black mutineers ultimately rejected or ignored such advice because they had exhausted peaceful and patient options.

Black soldier rebellions against a counter-revolutionary southern society and military hierarchy began early in their Reconstruction duties. The difficulties of reconstructing the South often drove black troops to quickly and directly retaliate against white civilian abuse instead of seeking slower, official justice from their superiors. When enduring white civilian hostility, African-American troops needed to make cost-benefit analyses when deciding risky courses of action to defend themselves and their comrades, just as they did when they reacted against abuse from white officers.

Men of the Fifty-seventh U.S. Colored Infantry (USCI), stationed at Fort Smith, Arkansas, near the town of Helena, were among those blacks who revolted against whites who opposed the egalitarian vision of emancipation and Reconstruction. Originally called the Fourth Arkansas Infantry (African Descent) and created in December 1863, the Fifty-seventh spent the war aiding Union operations against their state's Confederate forces. In August 1865, the unit moved to Fort Smith, from which it upheld civil order in the surrounding area. Here, regiment members engaged in mutinous behavior in early January $1866 .{ }^{263}$

\footnotetext{
262 "The Fifteenth Amendment," Rochester Union Spy, April 29, 1870, https://access.newspaperarchive.com/ (all quotes).

${ }^{263}$ Robert Patrick Bender, "Fifty-seventh Regiment, United States Colored Troops (US),"

http://www.encyclopediaofarkansas.net/encyclopedia/entry-detail.aspx?search=1\&entryID=6256. During the Fort
} 
On January 2, 1866, Fifty-seventh USCI troops struck back against perceived injustices from both the Army and southern society. Private Thornton Gamble, a field hand from Virginia who enlisted at Devalls Bluff, Arkansas, in March 1864 at age twenty-two, was tried for a range of offenses. He illegally carried a pistol in the streets of Fort Smith, disobeyed an order to return to camp, and made threatening language to an officer.

The mutinous acts illustrated the African-American commitment to bodily autonomy. The private reportedly proclaimed the following, after which he relocated a revolver from his boot to underneath his shirt and went to a store owned by a Mr. Shaw: "God damn that long nosed (Colonel) Craig, he had better wear his shoulder straps, or stay in the garrison." As Craig himself testified, he observed a dozen members of the regiment occupying a corner and speaking in an "apparently excited manner" that night. John King, a civilian, heard similar commotion. Due to this behavior, the colonel ordered those on duty to head to the guard house or to the fort, while those not on duty needed to return to their camps. Craig described the response to the command as done "in a sullen manner." An unidentified soldier refused to comply until a guard seized him. Craig added upon cross examination that he failed to disclose his rank and wore civilian garb. J. H. Harris testified remembering seeing Craig having "a difficulty with a colored soldier" outside his store. A white soldier who formed part of Craig's guard saw the colonel order Gamble arrested and sent to the guard house. The white soldier, Private William Cox of the Sixty-second Illinois Infantry, then observed Gamble walk toward the river. Gamble approached Cox, asking about Craig's location. After Cox informed him the colonel had gone to the post office, Gamble stated that he desired to inform Craig he would not go to his quarters and "hadn't

Smith duty, forty-six soldiers married women through the fort's Freedman's Bureau office, forming the first African-American marriages with legal protection. See footnote 21 in the previous chapter for an account of a mutiny in the regiment against orders to relocate to the West. 
done anything noway." Promoting his commitment to martial masculinity, he asserted he would rather die first. Stating that "he had always been a good soldier," and defending his right to control his own movements, Private Gamble denied Craig the "right to order him to camp." Comrades testifying for the defense mentioned that Gamble received the order from Craig but did not include the harsh language. Gamble's captain, Alfred Proctor, defended the private's "good" character and clean record as a soldier, except for two or three trips to the guard house, for which he was never court-martialed. ${ }^{264}$

Despite the defense's witness testimony and the faulty memories of several prosecution witnesses, the court convicted the defendant of all charges while clearing him of certain specifications. They sentenced him to two months of pay forfeiture and hard labor, a relatively light punishment. He returned to duty in February 1866, eventually serving as a teamster that summer and fall and mustering out in November. ${ }^{265}$ Gamble's recorded statements fit within the general trend of African-American soldiers desiring personal autonomy, even within the military command structure. After moving across the Upper South to become a Union Army recruit, fighting Confederates, and observing the process of emancipation and Reconstruction in Arkansas from the wartime to postbellum periods, Private Gamble had set a standard for individual freedom which he refused to abandon without resisting.

Also on January 2, 1866, Private Warner Wilson committed a separate offense that amounted to the cousin of mutiny: the race riot. He allegedly joined other enlisted men and black civilians in conducting a "(riotous) disturbance and breach of the public peace" in Fort Smith. A farmer originally from Missouri, Wilson had enlisted in Cairo, Illinois, in September 1863 at age 25. While it is unclear if he was free or enslaved, his action and subsequent legal maneuvers

\footnotetext{
${ }^{264}$ Proceedings of a GCM, Trial of Thornton Gamble, MM-3730, folder 1, RG 153, NARA.

265 Thornton Gamble Service Record, NARA, www.fold3.com.
} 
during his court-martial convey that he was determined to fight racial injustice. As an indirect influence, one could factor in evidence that he continued to receive seven dollars a month in wages for months after the federal government established pay equity. ${ }^{266}$

At the start of his trial, Wilson objected to Captain Simon Grate's presence on the court because "he did not think the Captain would be as fair to a colored man as he would to a white man." He added that Grate "would cashier a colored man when he would let a white man go." The captain denied either knowing the prisoner or holding the alleged prejudice. The court did not consider the challenge "sufficient," allowing Grate to remain. While the U.S. Army enforced black soldiers' due process rights, defendants had little or no chance at successfully challenging a judge for racial reasons. ${ }^{267}$

The alleged riot originated from a financial dispute and therefore touched on the socioeconomic aspect of African Americans' envisioned freedom. While Private Wilson conversed with Private John Marshall on the river landing, a boat came ashore. Its white captain and crew walked up the wharf. Wilson demanded that Edward Nowland, the steamer's captain, pay a debt owed to the private's brother, namely, the money owed to him for working on the boat. Marshall advised his comrade to "keep out of it" while "he was out of a fuss." Nowland agreed to pay Wilson's brother only when he received an order to do so. Ignoring Marshall's guidance, Wilson repeated his demand of an immediate payment. Nowland told him, "Go away from me you black son of a bitch and don't say anything more to me about it." Wilson replied that "you must not curse me." The boat captain drew his loaded pistol, threatening to "shoot your [Wilson's] head off." This threat, black soldiers testified, prompted the private to pick up a rock

\footnotetext{
${ }^{266}$ Proceedings of a GCM, Trial of Warner Wilson, MM-3730, folder 2, RG 153, NARA; Warner Wilson Service Record, NARA, www.fold3.com.

${ }^{267}$ Ibid.
} 
and prepare to throw it; white witnesses remembered seeing Wilson pick up the rock before Nowland armed himself. One of the two men accompanying Nowland, John King, seized the captain and pled with him not to shoot. At this point in the incident, Nowland went to town and Wilson returned to camp. ${ }^{268}$

Meanwhile, three other black troops observed, and may have contributed to, the altercation. One of these troops, Private Russell Hutchins, and along with Marshall, emphasized the civility with which Wilson requested the payment. However, John King once or twice heard the defendant say, "God damn you" after demanding the payment, and described both perpetrators' demeanors as noisy and "excited." King identified further hostility towards the boat captain, noting that he heard the defendant threaten to shoot anyone "who would draw a pistol on him" and at least one soldier or black civilian recommend that Wilson "get a musket and shoot him through the head." While running towards camp, King continued, Wilson called on his comrades "to keep their eye on him, and watch where he went." The defendant gave no statement. $^{269}$

The ways in which the court decided Wilson's court-martial as well as subsequent events illustrated the due process black defendants enjoyed while also revealing that defendants did not always receive sympathy for their motivations. The nature of the prosecution's evidence led to a conviction minus the "riotous" specification and a sentence of one month of hard labor. The judge advocate general, upon reviewing the case, emphasized the following events during the clash to justify ordering a revision of the decision: the drawing of weapons, the use of violent language, and Wilson's decision to repeatedly and threateningly make his demand. In another twist to this case, for unknown reasons, the court decided to acquit Wilson outright, which the

\footnotetext{
268 Ibid.

${ }^{269}$ Ibid.
} 
judge advocate general endorsed. ${ }^{270}$ The two January 2, 1866, incidents involving members of the Fifty-seventh USCI provide localized examples of how black men in uniform during the Reconstruction era felt that they needed to stand up and defend the social aspects of their new freedom. While Private Gamble resisted a violation of his freedom of movement, Private Wilson defended the right of his family to receive the fruits of their labor.

Hyperbolic commentary in the press surrounded the August 1866 mutiny of two companies in the Fifty-seventh USCI in Helena, Arkansas. This coverage fully displayed the clash between the black and white southern visions for reconstructing the former Confederacy. The regiment performed law enforcement duties in Helena over the past year. During the Reconstruction period, as it had since the Union began recruiting African Americans, the mere presence of black troops inflamed white supremacist sentiments. Yet, the phenomenon of black soldier mutinies injected an extra dose of anxiety into the ex-Confederate and Redeemer mentality. Prior to the mutiny, the Army's high command optimistically described the economic prospects of Arkansas' black troops, along with the degree of government protection of their civil and property rights. Earlier that summer, the African-American community of Helena joined with scalawags to promote black education and suffrage.

While the reason for the incident was the objection among the men towards being ordered to leave their home state and families to fight Native Americans in New Mexico, and while a clash between the mutineers and white civilians appeared to have happened, the white press circulated frightening reports of the incident. The Chicago Journal and the Weekly Wisconsin Union, for instance, stated that the mutineers had conducted a riot, seized control of the town, fired indiscriminately at white civilians, and threatened to massacre the town's white inhabitants

\footnotetext{
${ }^{270}$ Ibid. For other unknown reasons, Private Wilson deserted from Fort Smith on May 17. Despite being captured on June 6, under orders from Brigadier General Carlton, he immediately returned to duty.
} 
and burn down their homes. However, other accounts deemed the above one to be grossly exaggerated. As the Burlington Daily Hawk Eye Gazette put it, this version originated from “either illy-informed, or evil-disposed" individuals. An unidentified source the Gazette cited attributed the violence that did occur to a small number of drunk soldiers and an intoxicated white man who insulted the U.S. flag; most mutineers did not participate and instead tried to quell it. This source blamed the Copperheads for the sensational accounts. The Gazette and other skeptical papers put the casualty range from few to none and eventually described the "riot" as two soldiers peacefully disarming a drunk civilian who failed to hit a target with his pistol. The police briefly arrested all involved before releasing them. Even when black soldier mutinies of the Reconstruction era did not physically involve southern society, they could still do so as a specter. Uniformed, armed black men mutinying confirmed the ingrained white southern fear of insurrection and race war resulting from emancipation. ${ }^{271}$

White belief in a hostile ex-slave population persisted in the Helena area for the rest of Reconstruction. When an unknown assassin killed former Confederate General Thomas C. Hindman in September 1868, conservative whites used eventually-discredited evidence to pin the murder on a group of black men who acted on behest of the Radical Republicans and who also aimed to torch the town. The opponents of the long emancipation expected the same insurrectionary actions from all blacks, whether or not they were in uniform. ${ }^{272}$

\footnotetext{
${ }^{271}$ Robert Patrick Bender, "Fifty-seventh Regiment, United States Colored Troops (US)," http://www.encyclopediaofarkansas.net/encyclopedia/entry-detail.aspx? search=1\&entryID=6256; W. T. Sherman to J. A. Rawlings, Dec. 22, 1865; Boston Post, February 3, 1866; "Brevities," Coshocton Age, June 1, 1866; "The Helena Affair," Madison Wisconsin State Journal, August 11, 1866; "A Negro Soldier Riot at Helena, Ark.," Weekly Wisconsin Union, August 14, 1866; “The Helena Mutiny," Burlington Daily Hawk Eye Gazette, August 12, 18, 1866 (quote); "The Helena Riot," Fairfield Ledger, August 23, 1866; “Another Investigation," Janesville Gazette, August 15, 1866, https://access.newspaperarchive.com/.

272 "Racial Deviltry," Racine County Argus, Thursday, May 6, 1869, https://access.newspaperarchive.com/; Carl H. Moneyhon, "Thomas Carmichael Hindman (1828-1868)," http://www.encyclopediaofarkansas.net/encyclopedia/entry-detail.aspx?entryID=1672; Diane Neal, Thomas W. Kremm, The Lion of the South: General Thomas C. Hindman (Macon, Georgia: Mercer University Press, 1993),
} 
North Carolinian USCTs contributed to the long emancipation's Reconstruction phase by rebelling against racism in white southern society. During the Thirty-seventh USCI's occupation of Wilmington, racial violence repeatedly broke out. Instrumental to this were a number of factors: the Union high command deciding to restore control over the town government under its pre-occupation officials, antebellum-era state laws allowing for whites to violently retaliate against any black "insolent language," and the Thirty-seventh conducting patrols and guarding a railroad depot during an officer and supply shortage. Thus, here in Wilmington, the AfricanAmerican autonomy arising from the Civil War's social revolution operated on a loose leash and confronted forces representing a white supremacist order determined to overturn this inversion. In July 1865 , a provost guard ordered a Confederate veteran to remove his gray uniform, but the intervention of a white officer diffused the situation. The following month, a black soldier brawled with a white policeman who accused him of intoxication. Moreover, during the summer of 1865 , the Army's failure to adequately provide the Thirty-seventh with either officers or supplies led to white civilian complaints that black troops had plundered homes. The lack of sufficient additional white officers undermined the desire of commanders to keep black troops at their posts and away from white citizens. Intensifying racial animosities and overturning social customs further was the decision of civilian freedpeople to appeal to black troops for justice against white supremacist mistreatment, and of the latter to guide the former to the proper sources of redress. ${ }^{273}$

Just as USCTs from the Bluegrass State during and after the Civil War conducted mutinies in which they demanded the release of wrongfully disciplined comrades, black

\footnotetext{
238. A court indicted nine men, but it later released them after learning that the testimony linking them to the crime was false.

${ }^{273}$ Richard Reid, Freedom for Themselves: North Carolina's Black Soldiers in the Civil War Era (Chapel Hill: University of North Carolina Press, 2008), 284-286; Ira Berlin, The Black Military Experience, 735-736.
} 
Kentuckians in the Army did the same for imprisoned black civilians. Freeing a perceived victim of racial injustice could involve a revolt against military or civilian authority. In the following case, black soldiers did so in order to destroy a legal practice that reminded them of slavery.

Two members of the $119^{\text {th }}$ USCI, Corporal Amos Morton and Private Payne Morton, tried to advance the emancipation process in the fall of 1865. At age twenty-one, Amos, the slave of Billy Morton, enlisted in Frankfort, Kentucky, in late May 1865. Payne, owned by Major Hanelly, joined while eighteen years old at Camp Nelson, Kentucky, and served as a drummer. Both mutineers had signed up as the war ended and had done so with their masters' permission, due to the unique process of border state black enlistment. They thus lacked the motivations of mutineers angry over remaining in the Army after helping defeat the Confederacy, but they nevertheless had the personal experiences that would have reminded them of bondage when observing black men in chains. Their incidents took place as their regiment performed occupation duty, which it did in the Department of Kentucky from its birth in January 1865 to when it mustered out in April 1866. Never seeing Civil War combat, these USCTs' service mainly consisted of implementing Reconstruction. ${ }^{274}$

At around noon on October 8, 1865, at a railroad depot at Bowling Green, Kentucky, the Mortons and several others of the $119^{\text {th }}$ USCI forcibly released two black individuals convicted of stealing and larceny from Sheriff Berry Lisle's custody. Under orders to relocate to a Kentucky penitentiary, Lisle, along with his guards, moved George Van Liew and Lewis Johnson from their hometown of Clarkesville, Tennessee, to a railroad station in Bowling Green. Here, they were among a large crowd of civilians and occupying USCTs. Sherriff Lisle noticed a

\footnotetext{
${ }^{274}$ Amos Morton Service Record, Civil War Service Records, NARA, www.fold3.com; "Battle Unit Details: 119th Regiment, United States Colored Infantry," https://www.nps.gov/civilwar/search-battle-unitsdetail.htm?battleUnitCode=UUS0119RI00C.
} 
mulatto in civilian garb briefly talk to the convicts as they sat on a platform. After leaving, the man returned with a group of armed and visibly angry black troops who proceeded to walk suspiciously around the sheriff and his guard and to further converse with the prisoners. ${ }^{275}$

A heated exchange featuring references to past racial injustices and Civil War-era politics resulted. The soldiers, especially Payne, began to threaten Lisle and his guards that "if they had their way they would release those men," adding that the officials lacked the authority to handcuff and transport the prisoners. This physical confinement, as a guard heard the soldiers say, "looked a good deal like old times when they were slaves." When this guard, E. Herrmann, informed them that the convicts had been legally prosecuted, the soldiers denied the validity of the prosecution. The USCTs contended that since "those men in office" in Clarkesville "were secesh," they "would do anything to put handcuffs on a negro." Lisle heard Payne state that the prisoners' handcuffs were "played out in this country" and should be taken off. Other statements quoted by witnesses included one expressing that the soldiers "would lose their last drop of blood to release the prisoners." Another comment, which a witness attributed to Corporal Morton, connected the soldiers' removal of handcuffs to their original motivation for enlisting: they had "joined the army" to take "such things off.",276

Whether or not the Mortons accurately assessed the situation involving the prisoners, their rebellious actions represented the social disorder with which conservative whites associated emancipation. The situation continued to escalate. Lisle ordered the troops to desist, reminding them that civil law had legally prosecuted both prisoners. He requested a meeting with the soldiers' white officer, whom Amos contacted in town for this purpose. While the sheriff waited for the commanding officer, the soldiers assumed custody over the prison guards and refused to

\footnotetext{
275 Proceedings of GCM, Trials of Amos Morton and Payne Morton, MM-3526, RG 153, NARA.

276 Ibid.
} 
allow the group aboard their departing train. Despite a number of factors-Lieutenant Wright of the $119^{\text {th }}$ sending an order to release the prison guards, a guideline that civilian convicts fell beyond the jurisdiction of soldiers, and the sheriff commanding them to stand back - the soldiers drew their bayonets and issued a "stand back" order of their own, to which Lisle complied. Corporal Morton told those who still intended to free the convicts the following: "Boys, you do it at your own risk; I am not going to have anything to do with it." Payne and an unidentified soldier broke the prisoners' handcuffs with an iron object and threw the shackles to the ground. As the rescue took place, other soldiers protected the liberators and liberated by standing in front of them with their bayonetted muskets drawn. Meanwhile, men like Sergeant Nicholas Walker and Privates Turner Miller and Smith Paxton obeyed Wright's order to leave the prisoners and the station, and later testified for the prosecution. The mutineers fled towards their headquarters, threatening and cursing the sheriff and guard as they followed. ${ }^{277}$

The civilian authorities won the race to the headquarters, where Lisle initiated an investigation and manhunt with the white officers that in turn led to the mutineers' prosecution. Because the sheriff and another white official thought that "colored men dressed alike" and "look very much alike to me," they failed to locate the perpetrators, which included the two Mortons and two other unidentified troops, across Bowling Green. Eventually, the Army captured the two defendants. ${ }^{278}$

The due process rights African-American soldiers enjoyed since they first enlisted in 1863 still benefitted them in the Reconstruction period. Black witnesses for the prosecution made numerous statements expressing ignorance over the defendants' whereabouts, words, and actions. Even though the latter chose accommodation instead of resistance, and it is unclear what

277 Ibid.

${ }^{278}$ Ibid. 
their ultimate motivation was, one sees in their testimony an unwillingness to incriminate their comrades. Such testimony contrasted with the violent language white witnesses quoted to the judges. The court convicted the defendants of "conduct prejudicial to good order and military discipline" and sentenced them to a dishonorable discharge, forfeiture of all pay, and one year of hard labor at a state penitentiary. However, the judge advocate general determined that not enough evidence existed to show that the two men the defendants allegedly released were in the custody of the sheriff. Therefore, Amos and Paine won their release. While they proved unable to liberate George Van Liew and Lewis Johnson, they evaded substantial punishment for trying to do so. Such a result starkly contrasts with the racial discrimination in the civilian justice system, the system which had convicted Van Liew and Johnson. ${ }^{279}$

The phenomenon of African-American soldiers seeking the release of a comrade or a black civilian during the Reconstruction period shows that these troops were determined to eradicate all remnants of bondage. Also, the national context of this episode involving the Mortons explains their suspicions on the means by which white authorities convicted two freedpeople. According to these men, seeing two black men on whose hands a white-run legal system had placed chains signified that the emancipationist war aim of the Union cause had not been fully accomplished despite the death of the Confederacy. African Americans did not trust the ex-Rebels running the South in late 1865 to treat blacks and whites equally under the law. These whites in power during the time of Presidential Reconstruction made this perceived threat concrete when they used the law to control black bodies. In the most acute example, southern states passed Black Codes, which legally punished as vagrants any blacks not confined to

${ }^{279}$ Ibid. 
plantation or domestic labor. ${ }^{280}$ The Union had won the Civil War, and the peculiar institution was physically in shambles and on the verge of constitutional abolition. Nevertheless, black troops stationed in the Reconstruction South did not view their original wartime mission as complete because African Americans could still be dehumanizingly placed into shackles on the pretense of criminality. This reality vividly reminded black soldiers of the chains used to constrict bondspeople's mobility. Just as USCTs did during and after the war when they saw imprisoned comrades, the even mild physical constraints into which white policemen placed black prisoners drove blacks in uniform to take matters into their own hands to reverse a feared slide back into slavery. Absent rights they gained later, such as the vote and officeholding, the only ways to prevent a potential white counter-revolution from stemming the tide of black liberation were direct resistance to perceived unjust actions on the ground and taking the law into one's hands.

The above story foreshadows the racial solidarity the black working class exhibited throughout the late nineteenth century. In early June 1888, in Bramwell, Mercer County, West Virginia, a race riot occurred among coal miners involving similar fears of invalid prosecutions. During a strike for two weeks' pay involving every miner in the local district, police arrested one black miner for disorderly conduct. In response to rumors that their white counterparts planned to lynch this man, one hundred black miners marched on the jail to demand his release. When the guards refused, the band fired at the building with pistols. The arrival of a white mob sparked a riot. After several suffered wounds and several more found themselves in police custody, the rioters dispersed. Since black men throughout the second half of the nineteenth century saw their

\footnotetext{
${ }^{280}$ See for example, "Mississippi Black Code," Laws of the State of Mississippi, Passed at a Regular Session of the Mississippi Legislature, held in Jackson, October, November and December, 1965, Jackson, 1866, pp. 82-93, 165167, https://chnm.gmu.edu/courses/omalley/120/state/blackcodes.html.
} 
emancipation on the line whenever a white-run, untrustworthy criminal justice system, whether civilian or military, legal or extralegal, tried prosecuting another black man, they took collective action to halt the proceeding in its tracks. ${ }^{281}$

As the Bowling Green incident also illustrated, occupying black troops encouraged civilian freedpeople to pursue greater equality in their lives or directly fought on their behalf to preserve their newly-won freedoms. This first emerged from how black troops and their officers worked closely with the Freedmen's Bureau to reunite black families, craft fair labor contracts, provide relief, build schools, and protect freedpeople's new rights. Through advice, action, or their mere presence, black soldiers often drove ex-slaves to act more assertive. USCTs spoke out when they felt that the government failed to look out for freedpeople's welfare. Sergeant E. S. Robison, a Michigander of the $102^{\text {nd }}$ USCI, told Major General Q. A. Gilmore on August 7, 1865, that in Columbia, South Carolina, "the freedmen are Shamefuly abused." Robison cited a case in which General Horton threatened to arrest a freedman who reported that a white man had plundered his home, taking the perpetrator's side over the victim's. Robison informed Gilmore that "in this I Could not hold my temper After fighting to get wrights that White men might Respect By Virtue of the Law.” In addition, African-American soldiers sometimes, as Gregory Downs noted, "took matters into their own hands and punished white assailants without waiting for orders." For instance, if a freedwoman suspected that a white family had re-enslaved her child, black troops helped her retrieve her son or daughter. Like mutinies against U.S. Army officers, these efforts saw those struggling for black freedom use inflammatory language and force, all while risking disciplinary action from their officers. African Americans in both civilian

281 "Race Riots: Another Serious Collision Between White and Colored Miners in West Virginia," Mitchell Sunday Republican, June 3, 1888, https://access.newspaperarchive.com/. 
and military worlds maintained a mutually beneficial relationship based on inspiring and directly aiding each other. ${ }^{282}$

The 128th USCI is an example of a black regiment whose members were so mutinous that they seemingly could not stay out of the military justice system. Starting in the summer of 1865 , the revolts increased in number as the unit's occupation duty went deeper into the Reconstruction period. Many of the motivations for the era's mutinies can be found in this single regiment, making it representative. As this chapter opened, this unit launched revolts against white civilian harassment and officers' attempts to abuse their bodies and regulate their social lives. During the many incidents involving the regiment on Sullivan's Island, South Carolina, in 1866, participants cited past injustices from their 1865 occupation of Beaufort, South Carolina. This command's ranks thus proved more committed to advancing the cause of the long emancipation than most regiments. They represent the African-American devotion to a wide range of social rights and freedoms during the course of Reconstruction.

This regiment was one of six USCTs raised in South Carolina's Low Country. U.S. military occupation of this region early in the Civil War planted the seed of the Union's emancipationist turn and black enlistment, with abolitionist General David Hunter recruiting some of the first runaway slaves. Since Hunter also impressed black soldiers, those who eventually enlisted in the $128^{\text {th }}$ USCI would have learned about this early post-slavery threat to black family security. The $128^{\text {th }}$ was a late addition to the Union Army, organizing in April 1865. To a greater extent than the mutineers covered previously, those of the $128^{\text {th }}$ saw their military

\footnotetext{
${ }^{282}$ Sergt. E. S. Robison to Major General Q. A. Gilmore, 7 Aug. 1865, Letters Received, series 4109, Department of the South, U.S. Army Continental Commands, Record Group 393 Pt. 1, National Archives, in Ira Berlin, The Black Military Experience, 742 (first quote); Gregory Downs, After Appomattox, 52-53, 108-110 (second quote on 108). For an example of this from Tennessee in March 1866, see "The Negro Again," Philadelphia Age, March 13, 1866, https://access.newspaperarchive.com/.
} 
service more through the lens of Reconstruction occupation duty than through Civil War operations. Unlike the mutineers of the Border South who escaped bondage through a variety of methods, the $128^{\text {th }}$ USCI's South Carolinians generally enlisted on their own accord after fleeing plantations. $^{283}$

The $128^{\text {th }}$ USCI's rebellions took place during its home region's particular ordeal with Reconstruction. As South Carolina completed its transition from slavery to free labor, African Americans challenged a market ideology espoused by landowners that demanded a disciplined workforce and told them that they could freely leave an employer to find more favorable work arrangements. They instead advocated independent land ownership. Since they comprised a black majority and learned lessons in group organization from the Union Army, the Lowcountry's freedpeople were more likely than elsewhere in the state to engage in collective action to gain more control over their labor and lives. Black South Carolinians also organized politically through the Union League, Republican Party clubs, and other institutions like the church. Their collective culture entailed pressuring fellow blacks to vote and ostracizing those suspected of disloyalty, along with challenging injustices such as sharecropper evictions. This culture filtered into the $128^{\text {th }}$ USCI when its mutineers demanded that officers and civilians treat them more humanely and pressured their peers to join uprisings. ${ }^{284}$

Similar to the case of Mississippian John Higgins in the previous chapter, on June 21, 1865, at Camp Stanton in Beaufort, Private John Grear of the $128^{\text {th }}$ USCI acted mutinous while refusing to clean his weapon during an inspection. Only three months earlier, the Georgetown, South Carolina-born, twenty-two-year-old Grear had volunteered to join the unit at Hilton Head.

\footnotetext{
${ }^{283}$ Ira Berlin, The Black Military Experience, 37-39.

${ }^{284}$ Julie Saville, The Work of Reconstruction : From Slave to Wage Laborer in South Carolina, 1860-1870 (New York and Cambridge: Cambridge University Press, 1994).
} 
During his mutiny, when ordered to clean his weapon for an inspection, he declared that, "My gun is as clean as any man's; and I'll be damned if I clean it until I see the Colonel." When Captain E. J. Scranton and Sergeant William Emory arrested Grear, the latter allegedly tried to strike his two superiors. He scolded the sergeant with the words, "God damn you, I will mark you for this." The court convicted him of all charges and specifications except for the accusation that he tried to strike the captain. For three months, he forfeited ten dollars per month and underwent imprisonment at Fort Clinch, Florida, at which he endured close confinement, bread, and water every fourteen days. After returning to duty, he spent 1866 working in ordnance stores and on a boat crew. ${ }^{285}$ Black occupation troops throughout the Deep South resented what they deemed to be unfair orders to maintain cleanliness in a filthy environment, orders which formed part of a racist disciplinary regime. In Grear's case, we see a soldier displaying an understanding of military justice and hierarchy. He refused to comply with his captain's orders until he received input from his captain's superior, the colonel.

Mutinous incidents involving the $128^{\text {th }}$ USCI also entailed clashes with white civilians that brought disturbing reminders of slavery. For such an action, Solomon Rose faced the charge of "conduct prejudicial to good order and military discipline." On August 8, 1866, Rose threw a brick at Charleston civilian named Martin Wheelan, seriously wounding him. To explain why he did so, Rose informed the court that as he walked quietly through town, Wheelan's dog "ran at me and took hold of my pants." When he "told him to keep the dog off," Wheelan "sat still and laughed at me." He threatened to throw a rock at the dog if Wheelan did not retrieve the pet. Rose claimed that he intended to hit the dog, but the brick "glanced off the pavement and struck

\footnotetext{
${ }^{285}$ Proceedings of a GCM, Trial of John Grear, MM-2596, RG 153, NARA; John Grear Service Record, NARA, www.fold3.com.
} 
Mr. Wheelan.” However, Wheelan and another white civilian present insisted that the soldier designated the former as the target. ${ }^{286}$

While this incident might be the result of someone becoming angry when someone else failed to control his pet, the use of trained dogs by slave patrols to hunt down and bite runaways might have entered Rose's mind when such an animal left its white owner to attack him, a black man. After all, Rose had long lived in the Palmetto State's slave society as a laborer before enlisting in March 1865 at the age of thirty-five. Also, in the months leading up to Rose's act of retaliation, he served on detached duty at a freedpeople's camp in Charleston, where he likely learned of the brutal experiences of other ex-bondspeople. Regardless, for this action, Rose received a sentence of hard labor for thirty days, the first fourteen of which while consuming bread and water. ${ }^{287}$

On May 30, 1866, at Castle Pinckney, in Charleston Harbor, South Carolina, Sergeant Thomas Ramsey of the $128^{\text {th }}$ USCI conducted his own individual mutiny against what he perceived to be his officers' racial antagonism. A laborer from Charleston, S.C., who enlisted in March 1865 at age twenty-one, he received the following arraignments: disobeying orders, disrespecting his commanding officer, and "conduct prejudicial to good order and military discipline." Captain Robert Aiton and an ordnance sergeant caught the defendant in the act of unhooking a boat in the fort's boathouse, an action which only the ordnance sergeant had authority to do because the boat was his own private property. When they asked him to identify himself, Ramsey jumped into the water and swam to a point where he ran back to his quarters. The sergeant's wet clothing and shivering body enabled Aiton to recognize him and turn him over to the custody of First Lieutenant J. H. Van Vort. While in confinement, Ramsey violently

\footnotetext{
${ }^{286}$ Proceedings of GCM, Trial of Solomon Rose, OO-1796, RG 153, NARA.

${ }^{287}$ Ibid; Solomon Rose Service Record, www.fold3.com.
} 
and disrespectfully responded to Van Vort and Aiton's orders to be quiet. As he proclaimed, "I don't care a damned for you Lieutenant or the Captain...you are trying to take advantage of me." He added that, "I will have satisfaction when I see the Colonel and Major." Moreover, Ramsey accused the officers of racism "in an insolent manner": "I don't care a damn for you, you take the advantage of me because I am a colored man.” According to Sergeant Ramsey, the arrest and order to "shut up" occurred because, "I'm a negro and you are white." When the lieutenant inquired about Ramsey's reason for being in the boat house, the latter explained that he was under arrest for a previous offense and was trying to secretly bathe despite orders to remain in his quarters. Because the sergeant had attempted to steal a boat and had chosen an unideal location for a bath, the officers did not accept that excuse. Yet, Ramsey repeated that story in his statement at trial, adding that he fell off the boat and into the water accidentally and that Captain Aiton threatened to shoot him after arresting him. Finding Ramsey guilty, the court reduced his rank and sentenced him to five months of hard labor. ${ }^{288}$

What stands out about Ramsey's revolt is his understanding of the military hierarchy and its role in remedying sources of grievance. The sergeant rose up against his immediate superiors but sought the assistance of his high-ranking commanders. Unfortunately, when the court-martial later asked Captain Aiton why the prisoner decided to appeal, "to the Colonel or Major for the purpose of seeking redress for supposed wrongs," the trial transcript merely states that, "the question was objected to" and that the court dismissed the question "as being irrelevant to the case." However, Ramsey's case can be compared with that of Grear, who also believed that the high-ranking officers would overrule their immediate superiors. Perhaps soldiers viewed those at the top of the military hierarchy as more paternalistic and lower-ranking officers as crueler.

\footnotetext{
288 Proceedings of GCM, Trial of Thomas Ramsey, OO-1621, RG 153, NARA; Thomas Ramsey Service Record, NARA, www.fold3.com. It is not clear what Sergeant Ramsey's original offense was.
} 
Regardless, African Americans navigating the often turbulent emancipation process needed to look out for white allies who could ease their path. ${ }^{289}$

Not just racist military officers and civilians, but also white supremacist civil law enforcers, became the target of the $128^{\text {th }}$. In June and July 1866 , numerous members of the $128^{\text {th }}$ USCI added to their regiment's mutinous legacy when they were court-martialed for clashing with authorities at the Charleston City Jail. Privates Thomas Jenkins and William Johnson, while on duty at the jail on July 16, 1866, used "harsh and unbecoming language toward, and threaten[ed] to beat" U.S. Marshal of South Carolina J. R. M. Epping. The trouble began when the official arrived at the jail's gate to "execute a summons on Lieut. Manning" to implement a court order. After the guards - a corporal along with the two defendants - told him Manning was absent, he continuously requested the presence of a subordinate. Each time, the soldiers at the gate denied the presence or existence of the person. Despite making clear his position to, and demanding respect from, these guards, Epping revealed at the court-martial that his questions, "seemed to irritate them"; "they did not seem to think I had any right to ask them questions." The guards expressed skepticism over Epping's claims because he had neither a uniform nor a pass. The marshal's persistent demands to enter prompted the men to increase their level of animosity towards him, which the former termed "abuse," as indicated when they refused to provide him with their names and when they threatened to physically harm him. Johnson, according to Epping, "thrust his fist in my face" and declared, "damn you be off, or I'll make you go." When Epping threatened to report the men, Jenkins reportedly dared him to do so. During the confrontation, Jenkins conveyed that his orders prohibited him from letting any individual in except for those with a pass and uniformed officers. As a crowd began to form, the marshal

${ }^{289}$ Ibid. 
withdrew. Giving his side of the story, Jenkins issued a statement in which he related how he honestly reported to Epping the absence of any officer on duty at the institution. Jenkins noted how Epping tried to violate the orders regarding entry. Possibly helping the defendants' case was testimony, including that of a lieutenant, highlighting their clean records and good characters, and denying their use of profanity and violent threats. While the court-martial convicted them, the court cleared them of the specification related to threatening violence. The judges decided to be further lenient with Jenkins and Johnson, revoking passes for them for fifty days and releasing them. The court considered their thirty days in confinement as sufficient punishment. ${ }^{290}$

Soldiers in the $128^{\text {th }}$ USCI also continued the USCT campaign against military officer abuses in general and denials to engage in leisure in particular while stationed in the Charleston City Jail. There, on the evening of July 14, 1866, Private Prince Hamilton, a twenty-year-old laborer and life-long South Carolinian, objected to Lieutenant W. G. Bradford's refusal to grant him and other soldiers a pass to go into the city. Earlier, in November 1865, Hamilton had lost his sergeant stripes for leaving his post and going into Grahamville, South Carolina, along with other noncommissioned officers, without a pass. As Bradford informed the private, he had orders from the high command, "to allow no enlisted men out that night." Moreover, the granting of evening passes had not been a practice within the unit. According to the prosecution, the private

\footnotetext{
${ }^{290}$ Proceedings of GCM, Trials of Thomas Jenkins and William Johnson, OO-1781, RG 153, NARA. Armed clashes between white police officers and African-American soldiers in other units highlight the heated race relations of the Reconstruction South. In an illegible town, North Carolina, in mid-August 1866, Corporal George Moore of the Thirty-seventh USCI assaulted a citizen and steamer captain named William Hurnur (?), knocking him down. On May 12, 1866, in Charleston, South Carolina, Privates Samuel MacClease and Kelly Barber of the Thirty-fifth USCI fired their pistols at a lieutenant and a sergeant of the city police, attempting to kill them. Yet another clash between black soldiers and white civilian authorities a took place on Christmas Day near the $116^{\text {th }}$ USCI's New Orleans' camp. Private Weston Lewis of Company E faced the charge of "conduct to the prejudice of good order and military discipline" for joining with comrades and civilians in an assault on New Orleans city policemen. During the altercation, the defendant reportedly threw shoes and brickbats at the authorities. See Proceedings of GCM, Trial of George Moore, OO-3733, Trials of Samuel MacClease and Kelly Barber, OO-1621, and Trial of Weston Lewis, OO-1953, RG 153, NARA.
} 
persisted. However, Hamilton himself and the defense argued that he only asked for a pass once before Bradford called for the corporal of the guard tie him up by the thumbs. Hamilton declared that, "he would be damned if he would be tied up for" no legitimate reason "by any damned man." He expressed a willingness to endure jail and a court-martial as a consequence. He added that Bradford as well as other officers in the $128^{\text {th }}$ 's companies "had been tyrannizing over their men too much already." One witness testified hearing him declare that, "none of the officers of the regiment did right by the men after they got off from the regiment." Hamilton "had been a soldier long enough to know what was right" and wrong, as well as what constituted a soldier's duties and the regulations under which he served. Therefore, he recognized that, "no officer or nobody could tyrannize over him." A clerk at the jail described Hamilton's demeanor as "very noisy." 291

With the private resisting so forcefully, Lieutenant Bradford and Corporals Simeris Richardson and Joseph Rivers carried him to a jail cell, which led to court-martial proceedings. Bradford determined that Hamilton's offense warranted charges rather than corporal punishment on the spot. Despite witnesses testifying in his defense that he exhibited good discipline and character, Hamilton was found guilty of "conduct prejudicial to good order and military discipline" and of disobeying orders. The court sentenced him to a dishonorable discharge, forfeiture of pay, and a year of hard labor. However, the high command annulled the courtmartial proceedings, freeing the private in January $1867 .{ }^{292}$

Upon seeking authorization for an enjoyable evening, Prince Hamilton interpreted a denial as the latest example of officer despotism. He did not include specifics when reflecting on

\footnotetext{
${ }^{291}$ Proceedings of GCM, Trial of Prince Hamilton, OO-1781, RG 153, NARA (quotes); Prince Hamilton Service Record, NARA, www.fold3.com.

${ }^{292}$ Ibid.
} 
past officer actions, but this latest episode and the realization that he would be yet another black soldier tied up by the thumbs for a trivial offense proved to be the last straw for him. To be refused temporary, brief relief from constant police duty told black soldiers during Reconstruction that their white officers stood in the way of realizing their envisioned freedom.

The black soldier mutinies against denials to engage in leisure can be compared to civilian freedpeople experimenting with freedom and opposing interferences with these experiments. No longer human property, many freedpeople stopped working from sunup to sundown. When the southern states created by Presidential Reconstruction passed vagrancy laws and other black codes, former bondspeople held public gatherings at which they demanded the northern Republicans to help stop such attempts to "nullify the Proclamation of Emancipation," efforts which constituted, "practical reenslavement." This activism helped push the military to annul these laws and Congress to repeal them. To remind him of his new rights, a group of white soldiers told one freedman that “you didn't have to stay where you was, that you didn't have no master, that you could go and come as you pleased.” As Booker T. Washington wrote regarding the personal freedom ex-bondspeople gained, "they must leave the old plantation for at least a few days or weeks in order that they might feel really sure that they were free."293

That USCTs chose mutiny as their response to superiors' prohibitions against partaking in a "frolic" further revealed that African Americans viewed freedom from strict regulations of their personal behavior as critical to their full emancipation. Black men considered it their right to temporarily leave their place of work. These black occupation forces could count on the Republican-controlled Congress and the U.S. Army to repeal the black codes and to enact

${ }^{293}$ Quoted in Gregory Downs, After Appomattox, 85 (first), 52 (second), 123 (third). 
Radical Reconstruction. However, mutineers found little redress for the Army's own restrictions on personal autonomy.

Using his ability to speak strongly, native South Carolinian laborer and twenty-four-yearold $128^{\text {th }}$ USCI Private Charles Robinson fought racism both in an individual mutiny and in his subsequent trial. Before the court, Robinson objected to various members of the court. He started with Captain B. H. Manning's presence on the court. In most cases, the defendant answered in the negative when the court asked him if he opposed the membership of any officer on the body. According to this prisoner, Manning, "has been an enemy of mine ever since I have been in the regiment. He has never shown me justice in anything. I feel certain he would not deal justly with me." Robinson added specific details of Manning's past injustices: "while at Beaufort, he had me imprisoned several times for nothing." When Robinson "once... was in a row with a citizen," Manning "threatened to cowhide me." Manning responded with a statement of his own disputing Robinson's account, “except that I did imprison him. My action at that time was official, as Provost Marshal of Beaufort." Private Robinson also challenged Captain Robert Aiton on the grounds that the officer would not rule the case justly. At Beaufort, Aiton allegedly imprisoned Robinson for being absent from guard duty despite the sergeant of the guard relieving him. Aiton denied remembering either the prisoner or punishing anyone while serving as officer of the day. The third and final officer Robinson challenged was Lieutenant W. G. Bradford, whom the private claimed had "threatened to kick him once at Beaufort." Bradford responded that when he served as officer of the day at the time (approximately April 1865), Robinson occupied the guard house for fighting and interrupted him as he tried to question two men about the fight. When Bradford ordered Robinson silent until his turn to talk came, the private "said he would not do it" and "would talk when he pleased." This belligerence prompted the lieutenant to threaten to strike 
Robinson in the mouth. The court's other judges deemed the challenges "groundless," permitting Captains Manning and Aiton and Lieutenant Bradford to remain. ${ }^{294}$

When Robinson ceased making challenges, he was arraigned on the charges of disobeying orders and "conduct prejudicial to good order and military discipline." On July 10 or 11,1866 , at the $128^{\text {th' }}$ camp on Sullivan's Island, the defendant's company officer commanded him to cease "talking in mutinous language." He responded with the following language: "no God $d-d$ white man could stop his mouth. I am just as good as any white man and I will let you know it. And I would like to see the white man that can stop me from talking...we will see if the $d-d$ white officers will tell us to shut our mouths and put us in the Guard House." As his officers took him to the guard house, he continued to curse them. Overall, he, "did behave in a mutinous manner before enlisted men." For these statements, the court dishonorably discharged Robinson in December $1866 .{ }^{295}$ Robinson's trial presents another case study of the complex legal rights afforded USCT defendants, namely, the right to challenge. Robinson's case also contains some of the strongest racially-charged language one can see in a court-martial of a USCT member. For him, the great offense white officers had committed was trying to limit black soldiers' right to speak.

As a representative of Reconstruction-era black soldier rebellions, the mutinous behavior of the $128^{\text {th }}$ USCI in South Carolina in 1866 derived heavily from southern social life, local law enforcement's interactions with black troops, and the desire of newly emancipated black men to engage in leisure. When their officers, local police, or white civilians interfered in their lives,

\footnotetext{
${ }^{294}$ Proceedings of GCM, Trial of Charles Robinson, OO-3733, RG 153, NARA; Charles Robinson Service Record, NARA, www.fold3.com. After his service, Robinson married. Three years thereafter, according to his wife, he disappeared without a trace after going to work. See John Gourdin, Borrowed Identity, 161-162.

${ }^{295}$ Proceedings of GCM, Trial of Charles Robinson, OO-3733, RG 153, NARA; Charles Robinson Service Record, NARA, www.fold3.com.
} 
they revolted, sometimes violently. Like that of Higgins the year before, the $128^{\text {th }}$ 's individual mutinies began with an everyday officer-soldier exchange before escalating into a revolt against not just the perceived injustice of the moment but also against the overall mistreatment of his comrades. Mutineers' choice of language can be tied to republican ideology's tenets about power and freedom and their perpetual struggle. It also speaks to how African-American soldiers understood their military service and the rights they earned from it, including the right to avoid harsh punishments for minor offenses. Like the mutineers of the $109^{\text {th }}$ USCI the year before, those in the $128^{\text {th }}$ did not distinguish between the original trivial offense and the more serious offenses that followed due to his later, more belligerent behavior, the latter of which are often what led to the harshest discipline.

After the demobilization of the USCTs, the Reconstruction era remained one often characterized by paramilitary and extralegal violence. White supremacists opposed to the completion of the emancipation process, like those in the Ku Klux Klan, the Red Shirts, and the White League, lynched freedpeople and their white allies, and burned such symbols of black freedom as churches and schools. However, throughout Reconstruction, African Americans resisted white supremacist violence by forming their own paramilitary groups and violently defending their political and socioeconomic rights. The rebellious actions that USCTs committed as a means of directing Reconstruction towards their vision of socio-political autonomy early on remained part of their repertoire as they implemented Radical Reconstruction and later struggled to resist the tide of Redemption. ${ }^{296}$

\footnotetext{
${ }^{296}$ For paramilitary violence scholarship, see Allen W. Trelease, White Terror: The Ku Klux Klan Conspiracy and Southern Reconstruction (Harper \& Row, 1971); Stephen Hahn, A Nation under Our Feet; LeeAnna Keith, The Colfax Massacre: The Untold Story of Black Power, White Terror, and the Death of Reconstruction (Oxford: Oxford University Press, 2009).
} 
The tradition of armed self-defense that produced antebellum northern black militias and African-American soldiers and sailors, mutinous and non-mutinous, also gave birth to a new generation of black militia groups in the postbellum South. Across the ex-Confederacy, the new Republican-controlled state governments of the late 1860s and early 1870 s created segregated African-American state militias. Commanded by black officers, their duty was to maintain order and enforce Reconstruction laws in the near or total absence of federal troops. While black northerners struggled to gain state sanction for militia service before the Civil War, southern freedpeople succeeded in the last quarter of the nineteenth century. Through militia service, comparable to joining the military and conducting mutinies therein, black men could live up to the martial masculine ideal of using arms to defend their homes and communities from white supremacy. USCT veterans and life-long civilians filled the ranks of units like Prince River's company of Hamburg, South Carolina; Gilmer's Rifles of Mobile, Alabama; and the Richmond State Guard. During and after Reconstruction, these units proudly displayed the "martial skills of the Negro" through parades and drills. Like the Buffalo Soldiers, black militiamen enjoyed respect from fellow African Americans who saw them as disciplined and courageous, as well as derision from whites who equated them with arrogance and disorder. ${ }^{297}$

The Reconstruction experience made black militiamen, as well as more informal black paramilitary bands, recognize the need to take matters into their own hands and engage in armed self-defense if they had any hope of realizing the freedom of which they had long dreamed. As

\footnotetext{
${ }^{297}$ Bradley D. Proctor, “'From the Cradle to the Grave': Jim Williams, Black Manhood, and Militia Activism in Reconstruction South Carolina," American Nineteenth Century History, Volume 19, Issue 1 (December 2017): 1-33; Andrew D. Amron, "Reinforcing Manliness: Black State Militias, the Spanish-American War, and the Image of the African-American Soldier, 1891-1900," The Journal of African American History, Vol. 97, No. 4 (Fall 2012): 403409; Richmond Planet, October 3, 1891, quoted in Ibid., 47 ("martial skills"); Donna Lee Dickerson, The Reconstruction Era: Primary Documents on Events from 1865 to 1877 (Greenwood Press, 2003), 371-372; Andrew Lang, In the Wake of War: Military Occupation, Emancipation, and Civil War America (Baton Rouge: Louisiana State University Press, 2017), 210-236.
} 
white Republicans, the Army, and freedpeople moved to enact black voting and legal rights in the former Rebel states, Confederate veterans and other white paramilitaries seeking to restore conservative rule mobilized. In the lead up to local and state elections and a Radical constitutional ratification vote in April 1868, for example, African Americans in Wilmington, North Carolina, a town formerly occupied by the Thirty-seventh USCI, challenged the area's Ku Klux Klan intimidation campaign. By patrolling the streets over the course of four "tempestuous" nights, armed associates of the local Union League helped ensure ratification of the state constitution and the election of GOP officeholders. Through such force, coupled with other forms of organization and collective action, former slaves gained unprecedented political, social, and cultural power in the late 1860s. The emancipation process was marching forward. ${ }^{298}$ In a sign of the difficulty of preserving African-American freedoms, a more devastating episode of paramilitary violence broke out in the aftermath of a contested election in April 1873. With both the incumbent Republican sheriff and Democratic challenger claiming victory, and therefore possession of the courthouse in Colfax, Louisiana, this building became the site of the paramilitary engagement. Displaying a "semi-military character," four hundred black Radical Republicans garrisoning the courthouse spent several days fighting off white invaders from the surrounding countryside who wanted to "suppress negro domination." When conservative reinforcements from several other parishes arrived on Easter Sunday, the Radicals, which included Union veterans, held their position for two more hours. A white artillery barrage and infantry charge then broke the black stronghold. The attackers shot the remaining defenders, both those who tried fleeing and those who surrendered. The Colfax Massacre, which killed over one hundred freedpeople, serves as a reminder that when black men lived up to the martial masculine

${ }^{298}$ Steven Hahn, A Nation under Our Feet, 282-283 (quote on 282). 
ideal, they made a deadly choice. Those who did not resist the Redeemer insurgency could save their lives, but in doing so they risked paving the way to what eventually happened: the overthrow of Radical Reconstruction and the reversal of its hard-fought gains. ${ }^{299}$

Redemption reversed the emancipation process in terms of armed self-defense not only on paramilitary battlefields, but also in court rooms. During Reconstruction, competing legal philosophies clashed, with Republicans promoting the federal right of black militias to bear arms and Democrats arguing that the Second Amendment protected states from congressional interference in their militia systems. The former party cited the Fourteenth Amendment's due process and equal protection clauses, arguing they granted the federal government the authority to prosecute state-level violations of individual rights enshrined in the first eight amendments. Through the 1875 Supreme Court case U.S. v. Cruikshank, the states'-rights position, which narrowly interpreted the Fourteenth Amendment, triumphed in U.S. constitutional law for the next century. ${ }^{300}$

Cruikshank settled the question over whether the Colfax Massacre's perpetrators had violated their victims' Second Amendment rights under the 1870 Enforcement Acts. Section 6 of the legislation criminalized conspiracies to "injure, oppress, threaten, or intimidate any citizen with intent to prevent or hinder his free exercise and enjoyment of any right or privilege granted or secured to him by the Constitution or laws of the United States." Favoring the defendants, the high court ruled that the Second Amendment had "no other effect than to restrict the powers of the national government." States could regulate their militia systems and individual firearm usage free from federal encroachment, and the Fourteenth Amendment's protections applied to

\footnotetext{
${ }^{299}$ Andrew Lang, In the Wake of War, 230 (first quote); Ibid., 283, 292-294 (second quote on 294).

${ }^{300}$ Saul Cornell, A Well-Regulated Militia: The Founding Fathers and the Origins of Gun Control in America (New York: Oxford University Press, 2008), 167-210.
} 
state actions, not those of private individuals. This decision helped terminate active federal enforcement of African Americans' right to defend themselves from white oppression regardless of its source. ${ }^{301}$

Like black mutineers, African-American paramilitary troops understood that the war for their people's liberation did not end with the Confederacy's collapse. As Reconstruction historians have noted, building a biracial democracy ironically required first and foremost weapons and blood, not democratic cornerstones like ballots and civil debate. However, even if martial masculinity helped advance the emancipation process over the last decade, the Democratic Party's brutal re-conquest of the South over the course of the 1870s pushed it backward. To be sure, despite Redemption, black militia units persisted until the Jim Crow order emerged in the 1890s. In this second major postbellum setback to the emancipation process, in addition to black men losing their remaining voting rights and naval ships and other institutions becoming segregated, states disbanded their Reconstruction-era black militias. ${ }^{302}$

The conflict African-American mutineers and race rioters waged in the Reconstruction period against hostile white military and civilian personnel in southern communities foreshadowed similar struggles in the dark American racial climate of the late nineteenth and early twentieth centuries. With mixed results, the black rebellions of the 1860 s and 1870s occurred as the country rebuilt itself following a devastating civil war, a social revolution, and a counter-revolutionary backlash. As seen in the following chapter, while becoming citizens and escaping the status of property, African-American men secured a permanent place in the U.S. Army and primarily did so in the West. However, violations of this coveted status persisted.

\footnotetext{
${ }^{301}$ Ibid., 190-196 (first quote on 192); U.S. Supreme Court, United States v. Cruikshank, 92 U.S. 542 (1875), https://supreme.justia.com/cases/federal/us/92/542/ (second quote).

${ }^{302}$ Steven Hahn, A Nation under Our Feet; Andrew Lang, In the Wake of War.
} 
Later, as the country began fighting its first major overseas conflicts, while simultaneously grappling with the emergence of a new southern racial caste system, a later generation of black soldiers also felt the need to revolt against the latest perceived threats to their freedom. Their enslaved and USCT ancestors remained influential as models of black resistance, republican citizenship, and martial masculinity. Due to more ambitious goals and a renewed sense of urgency, the next chapter of the long emancipation process produced some of the most notorious black soldier mutinies in American military history. 


\section{Chapter 5}

\section{"We will reduce your houses and firesides to ashes and send your guilty souls to hell": Buffalo Soldier Mutinies from 1867 to 1917}

In 1893, after enduring constant white civilian mistreatment while stationed near the town of Crawford, Nebraska, the black men of the Ninth U.S. Cavalry issued a broadside warning bloody retribution. Titled "500 Men with the Bullet or the Torch," the document revealed that a white mob had yelled racial slurs at discharged Private James Diggs and would have lynched him if several comrades had not rescued him from jail and transported him to Fort Robinson. The document next contended that other members of their unit "have been beaten over their heads with six shooters by these thugs." The authors demanded that Crawford cease these injustices. If they continued to act in this way under "Old Glory," "we will repeat the horrors of San Domingo - we will reduce your houses and firesides to ashes and send your guilty souls to hell. We who would be free must themselves strike the blow."

Since he possessed this broadside, Sergeant Barney McKay, an ironworker from Indiana who had been among Diggs' rescue squad, was thereafter convicted of rioting for participating in a conspiracy to violently attack the Nebraska community and imprisoned at Fort Leavenworth for two years. Afterward, he repeatedly received rejections for a pension to alleviate lingering complications from an old wound. A "Declaration" he wrote in 1917 as an appeal to his conviction and pension application denials exposed his still raw bitterness towards his legal troubles. Attributing the broadside's authorship to a "secret society," he blamed his court-martial

\footnotetext{
303 "500 Men with the Bullet or the Torch,” April 28, 1893, Barney McKay, "Declaration,” August 11, 1917, quoted in Frank Schubert, Voices of the Buffalo Soldiers: Records, Reports, and Recollections of Military Life and Service in the West (Albuquerque: University of New Mexico Press, 2003), 177-179; Barney McKay to Hon. Franklin K. Lane, August 15, 1918, quoted in Ibid., 180-187; Frank N. Schubert, Outpost of the Sioux Wars: A History of Fort Robinson (Lincoln and London: University of Nebraska Press, 1995), 90-92. The broadside copied and pasted from an April 29, 1893, newspaper column under the "Yellow Cape" pseudonym in African-American Army Chaplain Henry V. Plummer's Omaha Progress. See Earl F Stover, "Chaplain Henry V Plummer, His Ministry and His Court-Martial," Nebraska History 56 (1975): 20-50.
} 
to his officers' desire to prosecute someone, general racism, and punishment for his opposition to lynching. He justified the document's language, albeit "improper," by pointing out that mobs had lynched three soldiers before the Diggs incident, in response to which their officers did nothing. According to McKay, he never received full due process, pointing to the failure of the courtmartial to speedily provide him with a copy of charges. He cited racist statements made against him by officers that torpedoed his pension applications. Regardless of guilt level, the broadside, as well as the decision of McKay's comrades to not testify against him during his trial, speak of African-American soldiers' solidarity in resisting bigotry. As American race relations deteriorated in the 1890 s, some black men still clung to the notion articulated by rebellious bondsmen that a prerequisite to liberty is the willingness to kill or be killed in defense of it. ${ }^{304}$ While a reaction against local ordeals, the threatened insurrection by a group of black troops in the 1890s reflected the numerous black soldier rebellions that broke out in the American West in the decades following the Civil War. The willingness of this set of men in one of the postbellum West's four all-black regular Army regiments to forcefully resist mistreatment while risking prosecution captures a key aspect of African Americans' lives in the late nineteenth and early twentieth centuries. As they moved from celebrating the death of one racial caste system to protecting themselves against the rise of a new white supremacist regime, a number of those in uniform ensured that the tradition of overt black resistance continued to flourish. The "500 Men" broadside's invocation of the Haitian Revolution demonstrates the link between a tradition birthed under slavery and efforts to promote black freedom by those who grew up a generation after bondage. The era's African-American regulars troops built on the foundation

\footnotetext{
${ }^{304}$ Ibid. Since the Army sent him to the military prison before the judge advocate general could review the case, he won an early release after five months. Eventually, McKay gained a modest stipend.
} 
laid down by those Civil War volunteers who felt the best way to ensure racial justice after slavery was to rise up against abusive white officers and hostile white civilians.

The three previous major chapters in the era of African-American soldier mutinies cover relatively short time periods in which American politics and society dramatically changed, especially in the South. The next key moment in uniformed black men's revolts against white supremacy took place in the West across several decades. After the retirement of the Union Army's Sable Arm, a new black army, nicknamed the "Buffalo Soldiers"305 and tasked with securing their country's imperial designs, grasped the torch of mutiny for the rest of the nineteenth century and into the early twentieth. Just as USCT mutinies help us better understand the Civil War and Reconstruction years, those involving the first black regulars give us a lens into the period from Reconstruction to World War I. The former lived in the immediate shadow of bondage and as blacks began figuring out what freedom meant; the latter promoted black freedom as a new socio-political order increasingly threatened the progress blacks had made in the 1860s. They could vote and were no longer property, but the turn of the century proved that

\footnotetext{
305 The "Buffalo Soldier" name likely originated in the early 1870s from the Native-American warriors they fought. When the Tenth Cavalry fought the Comanches in 1871, the latter reportedly called them as such in response to observing the U.S. troops gruelingly march. Several accounts from white individuals in 1872 and 1873 noted that Natives used the nickname in reference to the similarity between buffalos' and African-American soldiers' woolly hair. While "Buffalo Soldier" appeared in subsequent press writings in the following decades and in twenty-century unit histories, the historical record indicates that no actual soldier referred to himself or his comrades with the term until the writing of a 1929 reminiscence. Scholars and history enthusiasts use the term almost universally. Historians like William Leckie and Bruce Glasrud have asserted that Indians intended it to have a respectful meaning because of the centrality of the animal to these tribes' lives and because Natives praised black soldiers' bravery and physical features. However, others, including William A. Dobak and Thomas D. Phillips, consider the nickname derogatory. See Account of Col. Benjamin H. Grierson, quoted in Walter Hill, "Exploring the Life and History of the 'Buffalo Soldiers,"' The Record: News from the National Archives and Records Administration, March 1998, 13, https://www.archives.gov/publications/record/1998/03/buffalo-soldiers.html; Frances Roe, Army Letters from an Officer's Wife, 1871-1888 (New York: Appleton, 1909), 62-65; The Nation, October 30, 1873, Volume 17, 286, https://babel.hathitrust.org/cgi/pt?id=pst.000068743659\&view=1up\&seq=366; Rueben Waller, "History of a Slave Written by Himself at the Age of 89," July 23, 1929, transcribed in Frank Schubert, Voices of the Buffalo Soldiers, 24-30; William Leckie, The Buffalo Soldiers: A Narrative of the Negro Cavalry in the West (Norman: University of Oklahoma Press, 1967), 26; Buffalo Soldiers in the West: A Black Soldiers Anthology, eds., Bruce Glasrud, and Michael Searles (College Station: Texas A\&M University Press, 2007), 5; William A. Dobak and Thomas D. Phillips, The Black Regulars, 1866-1898 (Norman: University of Oklahoma Press, 2001), xvii.
} 
whites could make these gains hollow. Three generations of Buffalo Soldier mutineers capitalized on the legacy of USCT resistance to oppression while also setting the stage for how a later generation of African-American military personnel revolted as the country approached the modern civil rights era, bridging the Civil War and World War II generations. While new motivators caused black men to decide to lead or participate in a mutiny, familiar ones stubbornly persisted. This new Sable Arm showed that African-American mutinies were intensifying their violent tendencies while nevertheless perpetuating a generations-old tradition of bloody resistance. Physical abuse moved from being one of several drivers to the sole motivator of black mutinous activity. In total, 51\% percent of USCTs (twenty-eight out of a sample of fifty-five) rebelled against physical abuse, with $14 \%$ of mutinies resulting from inadequate compensation and 35\% opposing unpopular orders. By contrast, all thirteen or 100\% of recorded Buffalo Soldier revolts reacted against some form of violence. ${ }^{306}$ Finally, a key feature of Buffalo Soldier mutinies was a sharp drop in the government's commitment to criminal justice rights that had previously afforded rebellious USCTs a substantial degree of legal protection.

While the Reconstruction South witnessed black troops help maintain peace against paramilitary violence as ex-Confederate states re-entered the Union, in the West, they again tried to prove their worthiness for citizenship through the martial masculine act of combat. Between the mid-1860s and 1870s, a number of USCT veterans and new black recruits enlisted in the regular U.S. Army, marking the first time since the formation of the republic that blacks became a permanent fixture in this force. After the demobilization following the Confederacy's defeat,

\footnotetext{
${ }^{306}$ Data based on spreadsheet in author's files. USCT data matches that seen in the previous three Army chapters.
} 
the smaller postbellum Army resumed its long-running conflict against autonomous indigenous tribes. In later decades, African-American troops served in colonial campaigns abroad. ${ }^{307}$

The motivations for some Buffalo Soldiers to revolt closely resemble those of the USCTs. Namely, they confronted the twin threats of racism from both officers and civilians. While they could count on some of their commanders to sympathize with, and defend, them, they also continued to suffer from white superiors' physical and emotional mistreatment. Therefore, one class of Buffalo Soldier mutiny matches those seen within the Union Army. While the African Americans making up the western U.S. Army defended white communities from hostile Native attacks, western whites were often just as much an enemy of black civil rights as they were in the South, especially in the South-West borderland of Texas. As a result, the violence between white civilians and black troops in much of the early postbellum South spread to the West between the late nineteenth and early twentieth centuries. In neither region could AfricanAmerican soldiers avoid grievances that the long emancipation process tried to rectify. With commanders, who had a duty to respectfully lead and uplift the rank-and-file, and civilians, whom black troops had sworn to defend, occasionally treating them as if they constituted an enemy occupation force at worst and a nuisance at best, some Buffalo Soldiers made sobering realizations. They concluded that the rebellious behavior that had weakened and eventually destroyed bondage and helped resolve the equal pay issue in the Union Army, despite great risks, was still needed to fully bring their people into the promised land of political, social, cultural, and economic freedom. The obstacles to this vision that mutineers and rioters had combated in the mid-1860s either persisted or adapted between the late 1860s and 1910s.

${ }^{307}$ William A. Dobak and Thomas D. Phillips, The Black Regulars, 3. 
Beginning in 1866, after the last USCTs mustered out, the U.S. Army began creating new African-American units, consolidating them into the Ninth and Tenth U.S. Cavalry and the Twenty-fourth and Twenty-fifth U.S. Infantry by 1869 . These four commands together comprised the "Buffalo Soldiers," and built upon the distinguished combat record of USCT units and the social revolution they helped spawn. Unlike the black Civil War veterans who revolted in opposition to military service in a distant land, others volunteered to do so as Buffalo Soldiers, which gave them high regard in their home communities. This latter group of troops who mutinied against racial discrimination and abuse did so because of a new gap in their expectations for, and the reality of, their planned careers in the postbellum U.S. Army.

The Buffalo Soldiers participated in the U.S. campaign of westward expansion. Making up ten percent of the regular forces, black troops served in an era when the frontier Army was small and its ranks mainly comprised of the working-class, black and white, native-born and immigrant. At outposts, soldiers engaged hostile Native bands, patrolled the Mexican border, constructed and maintained infrastructure and communication systems, and policed settler communities. Life mostly consisted of boredom, isolation, tedious drills and inspections, a harsh natural environment, and stern discipline. While white officers often praised the record of black enlistees in the Indian Wars and endorsed their presence in the Army, they possessed racist views about blacks inherently being immature, cowardly, and less intelligent. Positive words for black troops contained paternalism and condescension. White officers commanding the four regiments ranged from opportunists seeking career advancement to those who accepted the commissions reluctantly; only a minority embraced equal rights. This dynamic between officers and enlistees displays a high level of continuity from the time of the USCTs to the Buffalo Soldier era. ${ }^{308}$

\footnotetext{
${ }^{308}$ Ira Berlin, et. al., Freedom: A Documentary History of Emancipation, 1861-1867, Series II: The Black Military Experience (Cambridge: Cambridge University Press, 1982), 736-737; Garna Christian, Black Soldiers in Jim Crow
} 
The story of the Buffalo Soldiers' uprisings helps further the trend of scholarship since the 1970s of demolishing traditional images of western U.S. history. In the aftermath of the modern civil rights movement, and alongside the Revisionists' overthrow of the Dunning School in Reconstruction historiography and the rise of social history in Civil War studies, an explosion of scholarship gave long-overdue attention to the acute African-American presence in the regular Army. ${ }^{309}$ Buffalo Soldier mutinies thus bridge Reconstruction and New Western historiography. In doing so, the Buffalo Soldiers provide a window into the complicated trajectory of American citizenship rights. By fighting in the last chapter of the Indian Wars, the U.S. Army's black regulars tried expanding their own rights and opportunities while suppressing those of another marginalized group of Americans. Throughout their service, they advanced white America's imperial projects. They refute the longtime myth that only white-and red-colored peoples inhabited the extremely diverse American West. As James Leiker argues in a recent anthology, New Western History needs to avoid painting the Buffalo Soldiers "either as villainous enforcers of white oppression or heroic subjects of injustice." While their acts of resistance against white supremacy can cause one to place them in the latter category, a more nuanced analysis explains why they endured certain injustices, why they avenged these injustices by committing their own version of racially motivated atrocities, and why other Buffalo Soldiers

Texas (College Station: Texas A\&M University Press, 1995), xiii-xiv; Kevin Adams, Class and Race in the Frontier Army: Military Life in the West, 1870-1890 (Norman: University of Oklahoma Press, 2009), 5, 7, 13-14, 23, 171174, 177-184.

${ }^{309}$ William Leckie, The Buffalo Soldiers; John Carroll, The Black Military Experience in the American West (New York: Liveright Publishing, 1971); Jack Foner, "Blacks in the Post-Civil War Army," in Blacks and the Military in American History: A New Perspective (New York: Praeger Publishers, 1974), 52-71, 266-267; Arlen Fowler, The Black Infantry in the West, 1869-1891 (Westport: Connecticut: Greenwood Publishing, 1971); Marvin Fletcher, The Black Soldier and Officer in the United States Army, 1891-1917 (Columbia: University of Missouri Press, 1974); William Katz, "The Black Infantry and Cavalry," in The Black West: A Documentary and Pictorial History of the African American in the Westward Expansion of the United States (New York: Simon and Schuster, 1996), 199-244; Frank and Irene Schubert, On the Trail of the Buffalo Soldier: Biographies of African Americans in the U.S. Army, 1866-1917, volume II (Wilmington, Delaware: Scholarly Resources, 2004); William Gatewood, "Smoked Yankees" and the Struggle for Empire: Letters from Negro Soldiers, 1898-1902 (Urbana: University of Illinois Press, 1971). 
did not rebel. Just as black men neglected to emphasize the common oppression of all nonwhites, certain tribes like the Cherokee enslaved blacks and sided with the Confederacy earlier in the nineteenth century to better fit in white U.S. society. American race relations do not always take the form of the binary pitting whites on one side vs. black and other colors on the other. ${ }^{310}$ Black men's military service in, and civilian settlement of, the West shed light on Reconstruction's non-southern history, which in turn produced a new scholarly trend that frames westward expansion as part of a "Greater Reconstruction." In this telling, the death of slavery and the passage of civil rights legislation in the 1860s were only two of many components making up the Reconstruction of the American state as it tried securing federal authority and formulating its sectional and racial relationships on both an East-West and North-South axis throughout the mid-to-late nineteenth century. With the conquest of Native land and maintaining order taking federal priority over protecting freedpeople's liberties by the 1870 s, some African Americans relied on colonial service in uniform to try to realize their political and economic freedoms. Yet, since this service failed to persuade many white Americans to recognize these rights, the most frustrated among these troops used their weapons on not just the red and brown subjects of U.S. imperialism, but also its white designers. Despite moving West to escape southern racial violence, such violence followed them; whether they left or stayed put, they eventually clashed with white supremacy. Together, both the subjugation of indigenous Americans that the Buffalo Soldiers helped perpetrate and the rebellions they launched against hostile whites impeach the triumphalist narrative of Reconstruction. ${ }^{311}$

\footnotetext{
310 James N. Leiker, "Black Soldiers at Fort Hayes, Kansas 1867-1869: A Study in Civilian and Military Violence," in Buffalo Soldiers in the West, Bruce Glasrud and Michael Searles, eds., 5 (quote), 157-158.

${ }^{311}$ Carole Emberton and Eliot West have each written works that convincingly argue for the need to expand the temporal and geographic boundaries of Reconstruction. Both use the term "Greater Reconstruction." See Carole Emberton, "Axes of Empire: Race, Region, and the 'Greater Reconstruction' of Federal Authority after Emancipation," in Rethinking American Emancipation: Legacies of Slavery and the Black Quest for Freedom, eds., William A. Link and James J. Broomall (New York: Cambridge University Press, 2016), 119-145; Eliot West, The
} 
Since the 1960s and continuing to the present, the Buffalo Soldiers have acquired a mythical position in the national imagination, especially among African Americans. According to this myth, the Buffalo Soldiers were "forgotten heroes" who played a disproportionate role in "taming" the West and who bonded with their Indian enemies over their common oppression as two peoples of color. Such an image contradicts the welter of scholarship on these forces and the similarity in contemporary white and black views of Native "savages," but it is potent enough to shape monuments, popular culture, popular history, and even some academic writing. ${ }^{312}$ Looking at the less glorious aspects of the troops' careers, such as violent clashes with officers in camp and retributive slayings of civilians in bars and on streets, instead of fights with enemies on traditional battlefields, further impeaches the sanitized Buffalo Soldier myth.

The Buffalo Soldiers' acts of resistance illustrate how regular U.S. military service offered both opportunities as well as continued obstacles in the effort to complete the long emancipation. Once African-American soldiers detected mistreatment and injustice during their service, and found formal avenues of redress lacking, they rose up. Also, certain conditions that bred mutiny in USCT commands, such as officers' physical abuse of the rank-and-file, continued to damage morale and the officer-enlisted man relationship for years.

The first Buffalo Soldier mutiny resulted from a racial problem all too familiar to Civil War veterans. On April 9, 1867, at San Pedro Springs, near San Antonio, Texas, members of the Ninth U.S. Cavalry rebelled against brutal discipline, interpreting it as contrary to their full

Last Indian War: The Nez Perce Story (New York: Oxford University Press, 2009). Disagreeing with black leaders who encouraged black settlement of the West and recognizing the Native experience with white violence, Frederick Douglass encouraged African Americans to stay in the South and stand their ground to avoid a similar fate. See Frederick Douglass, "The Future of the Negro," North American Review, July 1884.

${ }^{312}$ Frank N. Schubert, "Buffalo Soldiers: Myths and Realities," Army History (spring 2001), 13-18. In an anecdotal example from the winter of 2016/2017, the current author observed numerous visitors at the Smithsonian's National Museum of African-American History and Culture donning Buffalo Soldier-themed jackets and other apparel, a testament to these troops' celebrated place in black historical memory. 
emancipation. The mutineers responded to Lieutenant Edward M. Heyl tying up three comrades by the wrists for neglecting to remove nose-bags from their horses' heads and cutting, beating, and shooting at one who escaped. Witnesses at the court-martial reported that before the unit reached San Pedro Springs in April 1867, while stationed in New Orleans and San Antonio for two months, the lieutenant earned a reputation for vicious racism. He reportedly whipped, punched, struck, tied up, and stabbed victims. Alcohol often fueled his sadism. Yet, the men of the Ninth Cavalry initially kept their composure and exhibited high morale until the mutiny. ${ }^{313}$

Thus, the actions that followed the most recent offense represented the last straw in a long-standing series of tensions. First Sergeant Harrison Bradford, a twenty-four-year-old Civil War veteran from Kentucky, persuaded the men of Company E to march to Lieutenant Colonel Merritt's quarters to complain. The force marched in an orderly column with undrawn sabres. When they approached Lt. Heyl's quarters, located along the way, Bradford called for them to draw their sabres. When the lieutenant came out and inquired into the column's purpose, Bradford cited the officer's brutal treatment of the three comrades, reminding him it was "the way you treated them...Y You do them so!" Heyl pointed his pistol at the sergeant, which prompted Bradford to charge with his sabre. The lieutenant opened fire, striking Bradford in the mouth. Several other members of the column joined this clash, including two Louisianan laborers named Corporal Charles Wood and Private Irving Charles. Lieutenants Seth Griffin and Frederick Smith arrived after hearing the shots. Coming to Heyl's defense, Griffin fired at Bradford. The wounded sergeant then sliced open the lieutenant's head from side to side with his

\footnotetext{
${ }^{313}$ Frank Schubert, Voices of the Buffalo Soldier, 31; Proceedings of GCM, Trial of Charles Wood, OO-2488, RG 153, NARA; Charles S. Kenner, Buffalo Soldiers and Officers of the Ninth Cavalry, 1867-1898: Black and White Together (Norman: University of Oklahoma Press, 2014), 72-76. In addition to abusing the men he commanded, Heyl's racial views were apparent in the name he chose for his strong black horse: "Nigger." White officers who served alongside him in the Army of the Potomac and in the forces of Manifest Destiny painted a drastically different picture. According to them, Heyl was a "gentleman" who was "always ahead of the other officers in looking out for the interests of his company." His black troops never saw this side of him.
} 
sabre, exposing Griffin's brain, a wound from which he died two days later. Company E rallied to help Bradford. Lt. Smith shot the sergeant twice, killing him. Irving Charles and Henry Johnson and a couple others swung their sabres at Smith in retaliation, wounding his arm. The lieutenant fired at this group too. As Charles put it, "because I was frightened and did not know which way to run," he ran in multiple directions. With other officers approaching, the soldiers dispersed. Initially trying to reach the Louisiana border, by April 25, the starving mutineers eventually returned to San Pedro Springs, where they entered custody. Meanwhile, the remaining soldiers stayed in their ranks as the blades and bullets flew. ${ }^{314}$

The military justice system pursued various paths to rectify the damage caused by the San Pedro Springs mutiny. In June, eight soldiers stood trial for mutiny. The judges distributed death sentences to all, which General Philip Sheridan endorsed. However, Judge Advocate General Joseph Holt recommended mercy for the convicted. He cited Lt. Heyl's harsh treatment of his men and the command neglecting to read the articles of war, which mentioned proper redress of grievances. The words Holt used to describe Heyl's cruelty included "shocking," "brutal tyranny," "savage treatment," "heartless," "disgraceful," and "ferocity." The statement continued, saying the mutineers rightfully thought their lives were in immediate danger. Due to contradictory testimony, Holt thought Corporal Wood's acquittal was warranted. Private Charles also received the benefit of the doubt. The circumstances of the event, the judge advocate general contended, mitigated punishment for any offense derived from it, and since the defendants had already endured "anxiety and imprisonment," they should only receive an "extremely light"

\footnotetext{
${ }^{314}$ Proceedings of GCM, Trial of Charles Wood, OO-2488, RG 153, NARA; Trial of Irving Charles, OO-2301, Ibid.; Charles S. Kenner, Buffalo Soldiers and Officers of the Ninth Cavalry, 76-78; Irving Charles and Charles Woods Enlistment Records, “Army Register of Enlistments, 1798-1917,” Microfilm Publication M233, NARA, www.fold3.com.
} 
punishment. This persuaded Secretary of War Edwin Stanton to commute the sentences. Charles and Wood immediately returned to duty; the other six were released after only six months. ${ }^{315}$

Meanwhile, Heyl only received a reprimand as discipline for his crimes. Merritt demanded a court-martial, but Sheridan and Grant feared that prosecuting Heyl would encourage greater insubordination in black units and damage the morale of their white officers. Instead, the two generals filled officer vacancies, which they blamed for the mutiny, and sent Heyl to another fort and under different superiors. Despite the lack of justice for Heyl, no subsequent evidence exists of him drunkenly abusing other black soldiers. He eventually won distinction for fighting Natives, served with the white Fourth U.S. Cavalry for fourteen years, and won a position in the inspector general's office. As Charles Kenner points out, "it is an all too revealing commentary on the racist mores of the late nineteenth century that misbehavior as heinous as Heyl's actions...would have so little impact on his subsequent career." In another sign of the postbellum U.S. Army maintaining a rigid racial hierarchy based on discipline, it dismissed at least three officers in the Ninth Cavalry in the 1870s for fraternizing with enlisted men. ${ }^{316}$ That Heyl avoided punishment altogether while those who resisted his cruelty spent months in prison and something as minor as fraternization cost other officers their careers showcases how much work remained in the long emancipation process. Further, Sheridan and Grant misidentified the situation; it was by fostering a culture that tolerated abuse that black troops were more likely to mutiny.

\footnotetext{
${ }^{315}$ Proceedings of GCM, Trial of Charles Wood, OO-2488, RG 153, NARA; Trial of Irving Charles, OO-2301, Ibid.; Charles S. Kenner, Buffalo Soldiers and Officers of the Ninth Cavalry, 78-80, 326. Ironically, previously Holt had ensured that Henry Wirz, Andersonville's superintendent, and Mary Surratt, mother of a John Wilks Booth accomplice, paid for their crimes with their lives.

${ }^{316}$ Charles S. Kenner, Buffalo Soldiers and Officers of the Ninth Cavalry, 79-82 (quote on 79); The Papers of Ulysses S. Grant: Volume 17: January 1-September 30, 1867, John Y. Simon, ed. (Carbondale and Edwardsville, IL: Southern Illinois University Press, 1991), 434. For gambling or drinking with their enlisted men, these officers were convicted of conduct unbecoming an officer and a gentleman.
} 
On the other hand, the military justice system was more forgiving towards this group of troops who endured officer abuse in mid-1867 than it was to another group in similar circumstances who rebelled two years prior. In 1865, Judge Advocate General William Coyl contended that the mutineers of the Twelfth USCHA, covered in Chapter 3, were subjected to the letter of military law regardless of the circumstances. By contrast, in 1867, a different judge advocate general recognized that barriers blocked the men's complaint channels, necessitating a bending of official rules concerning the prosecution of mutiny. Though racism from commanders plagued African-American soldier life throughout the black freedom struggle, Holt's handling of the San Pedro Springs mutiny suggested that with blacks becoming a permanent fixture of the postbellum U.S. Army, some whites were comprehending the ways in which this prejudice complicated day-to-day military life. Yet, the difference in these two cases could also stem from the same diversity in white racial attitudes that minimized or worsened the mutiny problem depending on the particular unit, personnel, location, and other factors.

The San Pedro mutiny highlights the choices uniformed black men needed to make when whites abused their own. As African Americans made clear since the days of slavery, freedom meant avoiding physical abuse. Those who served as defense witnesses mostly denied the charges and specifications against their comrades. That defendants could receive remitted sentences and recognition of due process rights after enduring cruel abuse shows the process of emancipation in action despite its incomplete nature. Regardless of the disciplinary violation, black regulars generally supported each other against tyrannical officers. ${ }^{317}$

\footnotetext{
317 The early Reconstruction era produced additional Buffalo Soldier mutinies, including one at Fort Cummings in December 1867. See Russell K. Brown, "The Last Civil War Volunteers: The 125th U.S. Colored Infantry in New Mexico, 1866-1867,” Army History, No. 92 (Summer 2014), pp. 6-18.
} 
Black troops fighting to neutralize Native-American resistance to westward expansion continued to revolt against their own oppression into the 1870s. The Fort Stockton mutiny of July 1873 proved among the most prominent examples. A recent piece from anthropologist Nicholas Eskow accurately contends that this event "was not simply an act of defiance or resistance, but a symbolic assertion of fundamental rights of citizenship and personhood that included, but extended far beyond, the impulse for justice.” This chapter further demonstrates this theme by incorporating earlier analyses into the framework of the long emancipation. ${ }^{318}$

At the time of the mutiny, 176 men from three companies - the Twenty-fifth Infantry's F and K Companies and the Ninth Cavalry's Company D-were stationed at Fort Stockton. This force consisted of Kentuckians and Virginians with a background in agricultural slave labor, northerners, and enlistees who had chosen a military career. The Ninth's Captain Francis Dodge described his black soldiers' conduct as "good" during the past spring and early summer. When this conduct changed, it surprised the commissioned officers and the fort's post traders. ${ }^{319}$

By mid-July, "trouble was brewing because of curious circumstance," by which Dodge meant a backlash against a fatal case of medical neglect. The victim, Private John Taylor, was a Civil War veteran born in Fredericksburg, Virginia, who had enlisted in the Twenty-fifth Infantry in New Orleans in July 1870. On April 30, 1873, Taylor saw Post Surgeon Peter J. A. Cleary, who had a reputation for questioning the sincerity of patients, due to chest pain. The doctor gave the private medicine but denied him a medical excuse. Comrades secretly substituted for his guard duty. After two additional attempts at medical treatment for a "misery" in his head,

\footnotetext{
318 “'Hoodoos' and Kangaroo Courts: The Near Mutiny at Fort Stockton," in Charles S. Kenner, Buffalo Soldiers and Officers of the Ninth Cavalry, 72-82; Nicholas Eskow, "Sympathy for the Loss of a Comrade: Black Citizenship and the 1873 Fort Stockton 'Mutiny," UC Berkley, 2018, 3, https://escholarship.org/uc/item/9nf8t9v5.

${ }^{319}$ Nicholas Eskow, "Sympathy for the Loss of a Comrade," 9-10, 43-44; Clayton W. Williams, "A Threatened Mutiny of Soldiers at Fort Stockton in 1873 Resulted in Penitentiary Sentences of Five to Fifteen Years," West Texas Historical Association Year Book, Vol: 52, 1976, 78-83, quotes from notes one, two, three, and four; Charles S. Kenner, Buffalo Soldiers and Officers of the Ninth Cavalry, 83.
} 
an angry Cleary sent him to the guard house for malingering. There, he suffered from intense heat, poor air circulation, and a lack of bedding. Soldiers heard Taylor thrash around and noticed him become "delirious." As his condition worsened, on July 9, Clearly treated him for "affliction of the brain" and opium poisoning. Private Taylor died the next day. Other than an enlarged spleen, the doctors could only point to various mental conditions as causes of death. Due to the era's scientific racism, Cleary based this conclusion on the notion that "many, if not most men of his race" were inherently superstitious. ${ }^{320}$ The treatment Taylor received was too little, too late.

Accusing Dr. Cleary of murdering Pvt. Taylor, dozens of traumatized soldiers at Fort Stockton organized meetings to discuss a response. The men decided on writing a formal complaint to the adjutant general. Nearly three-quarters of the fort's troops-129 of 180 - signed the resulting petition. Violent language witnesses claimed to hear during one gathering brought this protest into mutinous territory. Though he did not attend the event, thirty-year-old Private Allen Crawford of North Carolina testified hearing incriminating statements from an unspecified location. According to Crawford, Sergeant Solomon Holloman suggested that "all the soldiers of the garrison should fall in and go up to Dr. Cleary's and take him and kill him, and cut his cock off, and tie him to the flag pole." In this account, Jacob Lione and two or three others endorsed the macabre idea. Other alleged statements from the mutineers included that, "they needed no white officers to run the Post, and that they could do it themselves." 321

\footnotetext{
${ }^{320}$ Nicholas Eskow, "Sympathy for the Loss of a Comrade," 12-13, 15-19; Clayton W. Williams, "A Threatened Mutiny of Soldiers at Fort Stockton in 1873 Resulted in Penitentiary Sentences of Five to Fifteen Years"; Charles S. Kenner, Buffalo Soldiers and Officers of the Ninth Cavalry, 86. Recent research indicates that Pvt. Taylor might suffered from a fungal infection unique to the Texas desert as well as PTSD contracted in the Civil War. See Nicholas Eskow, "Sympathy for the Loss of a Comrade," 56; John Waller, Health and Wellness in 19th-Century America (Oxford: Greenwood, 2014), 217.

${ }^{321}$ Nicholas Eskow, "Sympathy for the Loss of a Comrade," 3, 6-7, 11-12, 19-20 (quotes on 20); Allen Crawford Enlistment Record, Register of Enlistments in the U.S. Army, 1798-1914, National Archives Microfilm Publication M233, NARA, https://www.fold3.com.
} 
The majority shot down these brutal recommendations. Among them was John Thomas, who stated that "we can take it in a better way" through a joint-statement. Holloman agreed to retrieve the paper for the statement. Engaging in the peer pressure often seen in mutinies, Holloman reported hearing several including Jacob Lione threaten: "any man who would see his comrade murdered and would not sign for his rights ought to be murdered." Sergeant Ellis Russell, George Ringold, and many others disagreed that any soldier should be forced to sign it. A committee consisting of Holloman, Ringold, Johnson, Houston Shelton, Russell, and Richardson collected statements regarding Cleary’s general mistreatment of troops. ${ }^{322}$

Sergeant Russell and Private Houston Shelton assumed the task of writing and composing the document, which they completed the next day, July 12. A former farmer from New Bern, North Carolina, Russell enlisted in the Twenty-fifth Infantry in 1870 and resided in the Gulf Coast port town of Indianola, Texas. Russell and other attendees resolved to make their meeting public knowledge. In a show of their solidarity and their preference for a formal redress of their grievances, the soldiers' letter began with the following: "We the undersigned enlisted men of this command have the honor of most respectfully calling the attention of the proper authorities (through the Department and Post Commander) to certain facts." Later in the introduction, they described Dr. Cleary's crime against Pvt. Taylor: "from malicious feelings of a personal nature," the post surgeon "refused to give or allow him proper treatment." The statement also demanded Cleary's censure as well as a federal investigation. It revealed that over the past year, the doctor had committed, "abusive and harsh actions...towards the enlisted men of this post." They added that, "not wishing to annoy our Superiors, we have born with it until now." Since the Taylor tragedy "is of such a serious and aggravating nature... we think it worthy of the consideration of

${ }^{322}$ Ibid., 20-23, 35 (quotes on 20). Another majority decision ruled against disrespectful language towards Cleary. 
the proper authorities." On July 12, the troops met to listen to readings of the statement before signing it "round-robin" style to prevent anyone from disproportionate prosecution. ${ }^{323}$

Dr. Cleary and the commissioned officers responded to the petition and to the aftermath of its signing. Cleary defended himself in a letter arguing that Taylor had proven to be a serial malingerer, making him untrustworthy. The post surgeon objected to the negligence charge, citing an honest misdiagnosis on his part and him repeatedly admitting Taylor to the hospital. While initially deeming it a justifiable response, most of the white officers began to develop concerns over the soldiers' acute fury and organization in response to Taylor's death. Commander of the Department of Texas, General C. C. Augur, reported that the "clannish and...excitable" nature of black troops put officers on perpetually high alert that "the whole...garrison" might revolt against them, "not as officers, but as white men."324

The extent to which the Fort Stockton mutineers seriously advocated violence is difficult to determine. Charles Kenner is correct that white officers exaggerated the threat posed by black men to their safety. The era's whites often exhibited paranoia over potential racial violence. Yet, their fears might not have been fully unfounded. Court-martial testimony, if accurate, shows that at least a minority of the mutineers were angry enough to consider violence as an option. Taking into consideration other mutinies in which perpetrators discharged weapons, rhetorically invoked martial masculinity, and pressured comrades, it is perhaps surprising that the Fort Stockton

\footnotetext{
${ }^{323}$ Ibid., 21; Thomas, et. al. to AG, 12 July 1873, LR Dept. Tex., quoted in Ibid., 22-23; Ellis Russell Enlistment Record, Register of Enlistments in the U.S. Army, 1798-1914, National Archives Microfilm Publication M233, NARA, https://www.fold3.com. Dr. Clearly's late-career decisions further demonstrated that he placed less value on non-white lives. In 1891, while treating a tuberculosis epidemic among Apaches in Alabama, he gave the patients minimal care and concluded that they merely needed to become more acclimated to recover. See Mary C. Gillett, The Army Medical Department 1865-1917 (Washington, D.C.: Center of Military History, U.S. Army, 1995), 82. ${ }^{324}$ Nicholas Eskow, "Sympathy for the Loss of a Comrade," 23-25; Augur to Sheridan, August 5, 1873, LR, 3250 AGO 1873, M-666, NARA (quotes); The Reminiscences of Major General Zenas R. Bliss, 1854-1876: From the Texas Frontier to the Civil War and Back Again, Thomas Ty Smith, Jerry Thompson, Robert Wooster, and Ben E. Pingenot, eds., (Austin: Texas State Historical Association, 2008), 5, 153. Regarding his order that soldiers "rub themselves with stones or" bricks, Cleary framed such guidance as sarcasm against those feigning illness.
} 
episode did not escalate to bloodshed. On the other hand, the absence of one witness from the gathering at which he allegedly heard the most damning testimony invites skepticism. Maybe these witnesses sought to absolve themselves of suspicion by tapping into their officers' worst fears. Regardless, the decision by African-American servicemen to advocate changes in military race relations by going outside the chain of command, even peacefully, fed the specter of black insurrection in U.S. culture and threatened officers' absolute authority over the rank-in-file. ${ }^{325}$

Further evidence justifying these worries accumulated at the fort. When Major M. L. Courtney told Peter Cook and Henry Johnson to remove their names, they refused, stating that they would accept the consequences and challenged the military hierarchy, elevating their own autonomy. While Johnson denied the value of an officers' opinion, Cook stated that, "I prefer to decide the lawfulness of my acts." Witnesses spoke of "constant talk among men of showing that they were not to be imposed upon.” This levelling rhetoric occupied mutinous territory. ${ }^{326}$

Due to these circumstances, the commissioned officers met with the noncommissioned officers of each company to discuss how the protest movement violated Army regulations. The former reminded the latter of anti-mutiny provisions, as well as the prohibition of publicized and published discussions that judged the value of officers. If the petition signers removed their names, they would gain immunity from prosecution. The white officers gave them the benefit of the doubt regarding their knowledge of the dining hall meeting's illegality or purpose. The commissioned officers assumed that numerous signees followed the lead of their corporals and sergeants. They added that Cleary's diagnosis had medical corroboration and that the accusations of constant abuse were not previously known or were exaggerated. As Nicholas Eskow interprets it, "in urging people to disavow the letter they had signed," the officers, feeling threatened at the

\footnotetext{
${ }^{325}$ Charles S. Kenner, Buffalo Soldiers and Officers of the Ninth Cavalry, 88.

${ }^{326}$ Nicholas Eskow, "Sympathy for the Loss of a Comrade," 25-27 (third quote), 34 (second quote), 40.
} 
size of the protest, "were also attempting rob to this document of its legitimacy." Many of the signers thought these officers were bluffing, doubting that the officers would try and execute 129 men, hoping this solidarity would save them. However, twenty-six signees did agree to remove their name, often pleading ignorance of its contents and validity. A number later testified against their more determined comrades, from whom they felt a threat to their safety if they did not sign. Sergeant Holloman described the protest and threats on officers' lives in terms of "they," severing himself from the mutiny he helped orchestrate. Captain J. S. Tomkins was more sympathetic to the mutineers throughout, actively listening to the men and informing them of their activities' unauthorized nature without asking them to remove their names. It was perhaps this approach that contributed to the enlisted men's lack of defiant language made against him. ${ }^{327}$

Captain Francis Dodge eventually restored order and began the process of formally punishing the mutineers. On July 18 , he forwarded the letter to the assistant adjutant general, writing that the surgeon acted ordinarily and conclusively. Dodge bolstered the scientific racism theme when he asserted that "Colored troops are notorious for having 'miseries' in every part of their bodies, and if the Surgeon would excuse everyone who went to him for treatment, there would be very few left for duty." Also, he added, the enlisted men failed to understand the situation and lacked the right to officially criticize a superior. Identifying a "unity of action" among the soldiers, Dodge feared the situation would become violent because he predicted that the petition would not be sufficient for the mutineers. Earlier black soldier mutinies fueled these fears of escalation, and the judge advocate expressed similar concerns because of "three cases of mutiny being already on record against colored troops." After Dodge forwarded the letter, the fort's commanders proceeded to arrest those who played the most active roles in the incident and

${ }^{327}$ Ibid., 27-29, 31, 35, 37-38, 41-42, 47, quote on 29. 
refused to remove their name. Next, the Department of Texas' medical director transferred Peter Cleary to Fort Griffin. Twenty-one men, mostly noncommissioned officers, faced courts-martial between late August and early October 1873 for mutinous conduct, communication, and language. In their statement of final defense, the defendants revealed that "in signing the paper referred to in the Specifications, we were prompted solely by an earnest desire to secure what we believed to be our just rights." They also informed the judges that they had refused to take their case to Dr. Cleary directly, instead preferring "a Complaint through the proper channel." Further, they had refused to remove their signed names because it would constitute a denial of their charges. The statement concluded by attributing "any improper language" or misunderstanding of military regulations to their lack of sufficient educational opportunities. ${ }^{328}$

After deliberating, the court made a language revision in the charges, downgrading them from "mutinous" to "unauthorized." Some officers' reports identified the event as only a protest that could have escalated into "a very serious mutiny" without their efforts to quell it. Chauncey McKeever, the Department of Texas' assistant adjutant general, wrote that even if crafting the petition fell short of a mutiny, it represented "the next thing to it" because it encouraged violence. Though only a minority of the meeting attendees might have had bloody aims, McKeever added, that meant "no guarantee for the conduct of the many" regarding their "defiance of authority." Of those tried, all were convicted. Twenty received prison sentences ranging from one to fifteen years along with a dishonorable discharge and pay forfeiture. Yet, in

\footnotetext{
${ }^{328}$ Dodge to Asst. Adj. Gen, July 18, 1873, “Headquarters Records of Fort Stockton, Texas 1867-1886," M1189, reel 1, Vol. 3, NARA (first quote); Ibid., 30-45 (second quote on 39, third quote on 41, fourth quote on 42, fifth and sixth quotes on 45). Judge Advocate General Courtney likely was referring to Buffalo Soldier mutinies like San Pedro Springs, Fort Cummings, and an unidentified third one.
} 
the spring of 1874, citing a fair trial and sufficient punishment, Judge Advocate C. J. Smory of the Department of Texas ordered the Fort Stockton mutineers released. ${ }^{329}$

While a fragmentary historical record often makes it difficult to reconstruct the postmilitary lives of released mutineers, at least one from Fort Stockton left enough traces to show that he continued the struggle for the long emancipation. Ellis Russell, one of the petition's drafters, moved to the rapidly developing town of Galveston, Texas. Here, he worked on cotton plantations and on the docks. By the 1880 s, he became a prominent member of the community, pursuing careers as a postman, policeman, customs inspector, and insurance agent. Moreover, this period saw him become a protege of Norris Wright Cuney, an African-American political figure who helped organize, and championed higher wages for, black longshoremen. In these efforts, Cuney clashed with white unions. Both men shared membership in Texas' black Freemason community, which participated in postbellum black political struggles and faced discrimination from white Masons. In a sign of black solidarity, Russell maintained a long-life friendship with fellow Fort Stockton mutineer George Ringold. To further show his commitment to the long emancipation, Russell drew on the Haitian Revolution when naming his sons, Toussaint L. and Louverture. After unsuccessfully pursuing justice for a victim of white cruelty and apathy, Russell spent his life assisting the cause of socioeconomic and political justice. ${ }^{330}$

The Fort Stockton mutiny reminds us of the difficulty in determining what constitutes a mutiny. Those who did not classify this case as one could cite the lack of physical force or a

\footnotetext{
${ }^{329}$ Clayton W. Williams, “A Threatened Mutiny of Soldiers at Fort Stockton in 1873 Resulted in Penitentiary Sentences of Five to Fifteen Years"; Charles S. Kenner, Buffalo Soldiers and Officers of the Ninth Cavalry, 85, 90; Nicholas Eskow, "Sympathy for the Loss of a Comrade," 46-48.

${ }^{330}$ Nicholas Eskow, "Sympathy for the Loss of a Comrade," 50-52; Stephen Kantrowitz, "Brotherhood Denied: Black Freemasonry and the Limits of Reconstruction," in All Men Are Free and Brethren: Prince Hall and African American Fraternalism, Peter P. Hinks and Stephen Kantrowitz, eds., (Ithaca: Cornell University Press, 2013), 96; George Ringold Pension Record, NARA; George Ringold Enlistment Record, “Army Register of Enlistments, 17981917," Microfilm Publication M233, NARA, www.fold3.com.
} 
work stoppage. However, the extreme language white superiors and black non-mutineers cited, the reported intimidation of non-participants, the initial charges of mutinous actions, and the dark anticipations of most officers, along with the human rights for which the defendants fought, warrants this event's inclusion in the narrative of black soldier mutinies during the long emancipation process. A key factor was the perception among officers that the enlistees were undermining their authority and improperly assuming such power for themselves.

The Fort Stockton mutiny of mid-summer 1873 shares elements of earlier black soldier mutinies while also suggesting that these rebellions were becoming more organized. These Buffalo Soldiers' use of the verb "imposed upon" to refer to the tyrannical abuse of white superiors matches the rhetoric of Civil War and immediate postbellum mutineers. The old African-American tradition of violent resistance thus consistently identified whites imposing their will on blacks as a main threat. Like 1860s mutineers sent to prison, the mutineers of the 1870s only served a fraction of their original sentence, proving that a military uniform still afforded black men greater protection of legal rights. Yet, the peer pressure against nonmutineers at Fort Stockton was more widespread than that of early cases in which one individual shamed passive responses to white officer abuse in the mid-1860s. Nearly three-quarters of a garrison agreed to formally, non-violently protest an injustice by circumventing their superiors and thereby overturning military hierarchy. This action went beyond the San Pedro mutineers' march to complain to a commissioned officer. To be sure, the equal pay struggle of the Civil War years also united entire units or close to it, such as the Fifty-fourth and Fifty-fifth Massachusetts.

Yet, by the time of the Fort Stockton incident, the early 1870s, African Americans were building on the foundations they constructed under slavery in the areas of organized selfgovernment. As Stephen Hahn informs us, bondspeople acted politically by operating 
communication networks across plantations and organizing communities based on kinship, work, leadership, and stealthy religious behavior. The Civil War enabled freedpeople to experiment with self-government while congregating in contraband camps and enlisting in the USCTs. After the Union triumphed and the peculiar institution collapsed, blacks registered to vote, won public office, electorally mobilized, participated in state constitutional conventions, and orchestrated the passage of the Reconstruction Amendments. Moreover, they reunited families shattered from slave sales and formed independent churches, legal marriages, and labor unions. AfricanAmerican men who enlisted in the Buffalo Soldiers brought with them their people's experience in more formal organization that Radical Reconstruction had emboldened them to undertake. ${ }^{331}$

There are signs from the Fort Stockton mutiny that black mutineer demands were becoming more ambitious. Regarding the comment that the troops could run the fort without white officers, this case saw black soldiers pursue a greater levelling of the military's racial hierarchy. No longer did black soldiers frustrated with racist abuse merely demand more just treatment from white officers that properly recognized their masculinity, humanity, and citizenship rights; now they began concluding that the only effective solution was the elimination of white command of black units altogether. The persistence of white abuse of black soldiers almost a decade after the end of the Civil War drove some to the realization that a racial hierarchy built within the military command structure could not be reformed, but only eliminated. It is perhaps no coincidence that a controversy regarding racial discrimination in officer commissions heated up a year after the Fort Stockton mutiny. ${ }^{332}$ Foreshadowing the

\footnotetext{
${ }^{331}$ Stephen Hahn, A Nation Under Our Feet Black: Political Struggles in the Rural South from Slavery to the Great Migration (Cambridge and London: Harvard University Press, 2003).

332 See the case of Cadet James W. Smith, whom West Point denied a commission despite being well-qualified. "Cadet Smith," Columbus Daily Enquirer, August 5, 1874, https://access.newspaperarchive.com/; "The Black Boy at West Point," Brooklyn Daily Eagle, June 8, 1870, Ibid.; Adams Kevin, Class and Race in the Frontier Army, 182.
} 
Spanish-American War's "Mutinous Sixth," ${ }^{333}$ this 1873 incident reveals that African Americans recognized that to more thoroughly protect their bodies from white control, they should deny whites the ability to command them in a rigid hierarchy. Following the Twenty-fifth's lead, in December 1886, enlistees in the Twenty-fourth Infantry, stationed at Fort Elliot in North Texas, held a parliamentary gathering to resolve their own troubles autonomously. ${ }^{334}$

As nineteenth-century African-American scholarship in general and black soldier mutinies in particular show, deprivation of personal and bodily autonomy and barriers to social advancement constituted some of the main grievances of the black freedom struggle. At Fort Stockton, soldiers thought Private Taylor and anyone else who visited Doctor Cleary suffered a similar injustice because they involuntarily returned to work before the completion of their recovery. Comparing Cleary's medical care and Dodge's dismissal of black knowledge over their own medical needs to slavery's racial hierarchy, Nicholas Eskow described the doctorpatient relationship at Fort Stockton as one under which "the Black man had no real authority over his own body, and was not competent enough even to understand his own health."’335

The Fort Stockton mutiny exists within the broader history of medical neglect and abuse in the nineteenth century's African-American units, dating back to the USCTs. In July 1864, an orderly sergeant in the First U.S. Colored Infantry named George W. Hatton suffered an example in a hospital after incurring a wound at Petersburg, to which he ascribed significance for the

\footnotetext{
${ }^{333}$ See the opening vignette of the introduction.

${ }^{334}$ This group did so to censure three comrades because they allowed highwaymen to disarm and rob them. Like the Fort Stockton mutineers, the Army's justice system prosecuted the meeting's attendees for illegally assuming the disciplinary role of their superiors. The offense stunned the court-martial judges. See Army and Navy Journal 24 (December 25, 1886): 431, (January 15, 1887): 497, (March 26, 1887): 695, quoted in Frank Schubert, Voices of the Buffalo Soldier, 149-152.

${ }^{335}$ Nicholas Eskow, "Sympathy for the Loss of a Comrade," 54-55 (quote on 54); R. J. Young, Antebellum Black Activists: Race, Gender, and Self (New York and London: Garland Publishing, 1996), 74; Margaret Humphreys, Intensely Human: The Health of the Black Soldier in the American Civil War (Baltimore: John Hopkins University Press, 2008), 20.
} 
broader cause of black freedom. For him, the "great wound" from which he agonized was a doctor's decision to ban him from going home to visit his parents on a furlough, like white soldiers could. He reflected on the past and on the future: "Such deception as that I thought was crucified at the battle of Fort Wagner [July 18, 1863]; buried at Milliken's Bend [June 7, 1863]; rose the third day, and descended into everlasting forgetfulness in the Appomattox River at the battle of Petersburg." He asked, "when, oh! when can one of my color, and in my position, at this time, find a comforter? When will my people be a nation? I fear, never on the American soil; though we may crush this cursed rebellion." Hatton's prediction that the Union winning the Civil War was more likely than blacks enjoying a full emancipation proved prophetic. ${ }^{336}$

To be sure, other Buffalo Soldiers praised their medical care. While it may reflect the relatively greater opportunities for black soldiers and/or the medical advancements of the end of the nineteenth century, in 1899, Sergeant Major Edward L. Baker, Jr., of the Tenth Cavalry, described the enlisted man's health as "far better in service than out." His "medicines are of the modern character and medical attendance comprises the very best surgical skill.” Also, Baker documents a welter of educational resources on Army posts, another improvement from Fort Stockton in the early 1870s. Further, while the Twenty-fifth Infantry's John Taylor died from medical skepticism and racism, George Washington of the Tenth Cavalry, who served between 1867 and 1875, received continuous proper treatment for asthma by doctors. ${ }^{337}$

\footnotetext{
336 “George W. Hatton, Orderly Sergeant, First USCI, Hampton Virginia Hospital, July 1, 1864," Christian Recorder, July 16, 1864, quoted in Edwin S. Redkey, A Grand Army of Black Men: Letters from African-American Soldiers in the Union Army, 1861-1865 (Cambridge: Cambridge University Press, 1992), 256-257; For more on poor medical care in African-American units, see Joseph T. Glatthaar, Forged in Battle: The Civil War Alliance of Black Soldiers and White Officers (Baton Rouge: Louisiana State University Press, 1990), 187-195; VA Pension File SC 138442, John F. Casey, NARA, quoted in Frank Schubert, Voices of the Buffalo Soldier, 145.

337 "The Environments of the Enlisted Man of the United States of To-Day," Georgia Baptist 19 (April 13, 1899): 1, quoted in Frank Schubert, Voices of the Buffalo Soldier, 210; VA Pension File SO 1157895, "Deposition of George Washington," September 5, 1905, quoted in Ibid., 227-229.
} 
A Ninth U.S. Cavalry private's rebellion against a white noncommissioned officer in the next decade helps determine whether the Fort Stockton incident suggested a trend of greater militancy by the late nineteenth century. As Buffalo Soldiers scholar Frank Shubert introduces the episode: "a new generation of black soldier was emerging in the 1880s, a group of men who would not tolerate the bullying leadership style of men like" the sergeant discussed hereafter. ${ }^{338}$

In August 1884, newly enlisted Private Edward Hamilton, a twenty-two-year-old miner from Barboursville, West Virginia, charged First Sergeant Emanuel Stance with "always pecking after me and using abusive language towards me, and did ill treat me in various ways." Since the sergeant denied him permission to state his grievances to the commander, Hamilton concluded "that there was no justice, or that I had no rights that he (the 1st Sergt.) was bound to respect." He felt that he lacked any other recourse. Upon enlistment and in his short period of service, the Army told him that he would "be treated as a man" if "I behaved myself and performed all duties required." Yet, his superiors did nothing as he endured constant abuse. He proclaimed that it was "very hard for a man to be called a Black son-of-a-bitch, threatened with bodily injury, and you have your brains knocked out, and not allowed to speak." For trying to "assert my rights," he received a prison sentence. Meanwhile, his abuser suffered no consequences. ${ }^{339}$

In contrast to the Fort Stockton mutiny, this case suggests more continuity than change. The example of a single mutineer standing up to abuse is more in line with older forms of overt black resistance than the Fort Stockton incident. Given the times in which he lived and his response to undesirable circumstances, the mutinous cavalryman likely would have felt both the

\footnotetext{
${ }^{338}$ Frank Schubert, Voices of the Buffalo Soldiers, 129 (quote).

${ }^{339}$ Proceedings of a GCM, Trial of Edward Hamilton, RG 153, NARA; Edward Hamilton Enlistment Record, “Army Register of Enlistments, 1798-1917," Microfilm Publication M233, NARA, www.fold3.com. For a similar case involving Sergeant Stance from the previous year, see Proceedings of a GCM, Trial of Moses Green, RG 153, NARA; Moses Green Enlistment Record, “Army Register of Enlistments, 1798-1917," Microfilm Publication M233, NARA, www.fold3.com.
} 
promises and disappointments that the black freedom struggle faced between the mid- and late nineteenth century. Born at the start of the Civil War, he grew up amidst the country's move from slavery to Redemption. It is possible he was less patient than the black troops of the 1860 s, who did not yet experience Reconstruction's collapse, but his actions and language resembled rebellious slaves and the mutineers of the Texas Expedition and San Pedro Springs. Like predecessors, Private Hamilton desired recognition of his full manhood as a soldier, and when denied that status, he felt obligated to fight for it instead of remaining passive. To the extent that African-American soldiers were becoming more militant, the first generation of blacks who grew up after slavery knew that resisting relics of bondage such as white abuse was all the more important as they hoped to do what their parents could not: establish a lasting biracial democracy. Fortunately for Hamilton, the Army permitted him to rejoin the ranks after his sentence rather than face the shame and poverty that accompanied a dishonorable discharge. In the 1880s, black soldiers still enjoyed legal rights, just as they had not yet lost the franchise. ${ }^{340}$ To be sure, African-American historians have demonstrated that this generation developed a reputation among whites for being more "uppity" than their formerly enslaved parents. As one Nashville-based black newspaper editor put it in 1889, "We are not the Negro from whom the chains of slavery fell a quarter of a century ago...We...being the equal of whites, should be treated as such." Pronouncements like this motivated southern states to pass disenfranchisement and segregation laws and to foster lynching outbreaks. To incentivize blacks to recognize their proper place via carrots instead of sticks, Confederate veterans pushed for the

\footnotetext{
${ }^{340}$ Edward Hamilton Enlistment Record, “Army Register of Enlistments, 1798-1917,” Microfilm Publication M233, NARA, www.fold3.com. While we do not know the subsequent circumstances, Private Hamilton's bitterness towards the nature of his military service clearly did not end with his individual mutiny. Three years later, in July 1886, he conducted a different sort of rebellion, deserting his unit.
} 
granting of pensions to former camp servants who exhibited loyalty to their masters during the Civil War and who replicated this role at veteran reunions. ${ }^{341}$

However, during the same period that saw figures like Lieutenant Heyl, Surgeon Cleary, and Sergeant Stance inspire rebellions against their sadism, a number of white officers in the Buffalo Soldier regiments, defended their troops' welfare. Colonel William R. Shafter, commander of the Twenty-fourth U.S. Infantry, respected and defended his men from racist harassment. When stage coaches denied them service, he successfully demanded a reversal in policy in his characteristically blunt, threatening tone, and when civilian authorities tried arresting one of his men for intoxication, Shafter refused to turn him over, deeming the attempted arrest "legal hazing." This protection of his black troops cost him command of Fort Davis and likely delayed subsequent promotions. ${ }^{342}$ While abusive officers could expect revolt in the ranks, commanders like Shafter earned enough respect to avoid it.

To fully understand the racial climate in which Buffalo Soldier mutinies against tyrannical officers operated, one should inspect violent examples of military-civilian relations in the West, especially Texas. Black U.S. troops found this region's white towns to be just as hostile to them as those of the South. Frank Schubert accurately describes Texas as the place where "the unreconstructed South met the untamed West." Historians have also wondered whether Texas' reputation for disproportionately mistreating black troops derives from its status as not just a regional borderland within the U.S., but also an international one encompassing the

\footnotetext{
${ }^{341}$ Kevin Levin, Searching for Black Confederates: The Civil War's Most Persistent Myth (Chapel Hill: University of North Carolina Press, 2019), 88, 97, chapter four; Quoted in David Goldfield, "Segregation and Racism: Taking Up the Dream Again," in Understanding the Little Rock Crisis: An Exercise in Remembrance and Reconciliation, eds., Elizabeth Jacoway and C. Fred Williams (Fayetteville: University of Arkansas Press, 1999), 30.

${ }^{342}$ Paul Carlson, "William R. Shafter, Black Troops, and the Opening of the Llano Estacado, 1870-1875," in The African American Experience in Texas, Bruce Glasrud and James Smallwood, eds. (Lubbock: Texas Tech University Press, 2007), 125-137. Also see the case of Lieutenant Powhatan H. Clarke. Though using racial slurs, he articulated his respect for them in letters. See Lieutenant Powhatan H. Clarke to his parents, May 4, 1886, quoted in Frank Schubert, Voices of the Buffalo Soldier, 139-140.
} 
often politically unstable countries of northern Latin America. When one factors in the explosion of USCT mutinies in response to their forced relocation from Virginia to the Lone Star State to potentially intervene in Mexico, the transnational interpretation carries weight and also compels us to extend the narrative to the 1860s. Most importantly, white citizens' racial prejudices clashed with black men's expectations of equal treatment due U.S. servicemen. ${ }^{343}$

The race riot form of Buffalo Soldier resistance became more prominent than standard mutinies against officers over the course of the half century after San Pedro Springs. Before 1890, five mutinies and three race riots occurred; the post-1890 years saw four actual or planned race riots and one episode in which soldiers revolted against both military and civilian personnel. ${ }^{344}$ While officer cruelty could become an issue at any time or location in the regular Army's area of operations in the West, civilian hostility in the context of Jim Crow's rise and officers' negligence in protecting their enlistees occupied the bulk of Buffalo Soldiers' attention.

Buffalo Soldiers' rebellions against civilians often saw the former shoot up a business or section of town when whites in the targeted location previously mistreated a comrade. In the early Reconstruction South, the soldiers-vs.-civilians form of race riot consisted of spontaneous confrontations in which troops engaged in self-defense. In the late-nineteenth-century West, by contrast, race riots entailed an initial clash or instance of civilian harassment followed by a retaliatory raid from the soldiers. This second step suggested greater organization and coordination among rebellious enlistees who acted independent from officers.

The frequency with which the Buffalo Soldiers conducted uprisings against civilians conjures the terminological issue. While these incidents fall outside of most definitions of

\footnotetext{
${ }^{343}$ Frank Schubert, Voices of the Buffalo Soldier, 31 (quote); Buffalo Soldiers in the West, Bruce Glasrud and Michael Searles, eds., 198. For a thorough examination of these competing racial agendas, see Garna Christian, Black Soldiers in Jim Crow Texas.

${ }^{344}$ Data based on spreadsheet in author's files.
} 
"mutiny," vengeful acts against white officers and white communities served the same ultimate goal of completing the long emancipation by forcing obstacles to it to surrender through collective or individual acts of protest and/or violence that broke established laws. The source of injustice proved mostly irrelevant, since these U.S. soldiers expected respect from both the superiors under whom they served and the civilians for whom they served. One can see the clashes between white civilians and Buffalo Soldiers in late-nineteenth-century Texas as a continuation of Reconstruction violence as well as an accompaniment to Jim Crow-era race riots.

These race riots have origins in the late Redemption years. In the late 1870s, members of the Tenth U.S. Cavalry retaliated against white civilian abuse in San Angelo, Texas. In 1877, Texas Rangers spotted Buffalo Soldiers drinking and dancing with local women. Angry at the presence of uniformed black men in a leisurely setting, the rangers pistol-whipped the troops. When the Tenth's commander, Benjamin Grierson, demanded an apology from the rangers' captain, the latter defended the right of his men to attack the entire Army garrison at Fort Concho. In response, the soldiers returned to the saloon armed and opened fire on the establishment, killing a bystander. At another saloon the following year, a group of white hunters cut off Sergeant George Goldspy's stripes and mocked him. The sergeant returned with some comrades, who fired their carbines at the hunters. In the resulting firefight, one civilian and Private John L. Brown died, while two whites and one black soldier suffered wounds. These fortunate troops avoided legal punishment. In both cases, Grierson defended his men. He refused to apologize to the Texas Rangers' Captain John Sparks, worked with the state adjutant general to fire Sparks, and denied Sparks' replacement jurisdiction when he tried arresting Goldspy. While the civil judiciary indicted nine cavalrymen for murder, they avoided trial. Into the late nineteenth century, black soldiers felt insulted by fellow Americans who infringed on their 
freedom to enjoy themselves on their off time and to proudly display ranks earned through merit. To defend their worthiness for rights under siege, they brought literal war to offenders. ${ }^{345}$

In this particular time and place, the Tenth Cavalry rebelled against civil law and American society, not their military command structure. Unlike their comrades in the Ninth Cavalry a decade ago, these men possessed no need to mutiny against a cruel officer. Regardless of their target, the Army's black resisters used the methods of martial masculinity to fight for greater recognition of their freedom. In contrast to these troops enjoying a commander who shielded them from prosecution, whenever a later generation of Buffalo Soldiers did battle with the non-military legions of white supremacy, they could expect certain punishment.

The Tenth Cavalry started a trend. Buffalo Soldier raids retaliating against a comrade's lynching fueled a broader effort that included vigilante revenge from black civilian bands, accounts of which predominated during the 1880s. In Athens, Georgia, in mid-July 1884, African Americans threatened to burn the town in retaliation after a police lieutenant received a “justifiable homicide” ruling for killing Sam Taylor when he refused to leave a sidewalk and resisted a beating. December 1889 saw black Georgians strike white policemen with their own clubs when the latter tried arresting the former for drunkenness. Black communities used armed self-defense for their right to peaceably assemble and engage in leisure. ${ }^{346}$

Amidst the documented riots in which African Americans banded to protect themselves, rumors of widespread African-American campaigns of death, fire, and screams spread. During a

\footnotetext{
${ }^{345}$ Frank Schubert, Voices of the Buffalo Soldier, 114; William and Sherley Leckie, The Buffalo Soldiers A Narrative of the Black Cavalry in the West (Norman: University of Oklahoma Press, 2003), 164-165; James N. Leiker, Racial Borders: Black Soldiers Along the Rio Grande (College Station: Texas A\&M University Press, 2009), 90. For black soldier-white civilian violence in another western state, Kansas, see "Black Soldiers at Fort Hayes, Kansa, 1867-1869," Buffalo Soldiers in the West, eds., Bruce Glasrud and Michael Searles, $157-181$.

346 "Riot in the South," Butte City Daily Miner, December 27, 1889, https://access.newspaperarchive.com; "The Southern States," Monmouth Warren County Democrat, October 20, 1887, Ibid.; "A Scared Community," Petersburg Pike County Democrat, July 24, 1884, Ibid.
} 
discussion of an 1879 incident where whites conducted a rampage against blacks who congregated and possessed weapons, the Waterloo Courier remarked that "such...is the dread of a negro-rising in the South, that the mere rumor that armed negros are assembling is enough to convulse whole counties with terror and fury." An 1882 report spoke of whites in places like northern Alabama and Oxford, Mississippi, who "were scared almost to death...they would be murdered before morning." The ways in which black insurrections tormented the white imagination compare with the specter of slave revolts in the antebellum era. The postbellum version of this specter found fuel through the greater ability of African Americans, civilian and military, to engage in armed self-defense during the period. It is likely that news of Buffalo Soldier vengeance made many white communities frightened that they would be next. ${ }^{347}$

African-American socioeconomic and political successes in the post-slavery era further fueled these fears, birthing Jim Crow. The rise of a black middle class in cities making up the New South made whites terrified for the safety of white women intermingling with imaginary black rapists. Also, the maintenance of black voting blocs two decades after Redemption and the Populist Party's biracial challenge to southern Democrats resurrected white fears about "Negro Rule.” Conservative whites responded by disenfranchising black men and segregating their towns, public services, and institutions. Simultaneously, a lynching epidemic took off, which extinguished several thousand black lives by mid-century. This occurrence disproved Booker T. Washington's doctrine of blacks earning rights through economic uplift and motivated a segment of the black population to assume W.E.B. Du Bois's mantle of agitation for full equality. Jim Crow-era mutinies and race riots shed additional light on the effectiveness of either approach to

\footnotetext{
347 “How Louisiana Was Carried," Waterloo Courier, January 29, 1879, Ibid. (first quote); “A Negro Uprising," Atlanta Weekly Constitution, October 24, 1882, Ibid. (second quote).
} 
civil rights. The long emancipation period taught black men that merely enlisting in the military was not enough to foster a widespread white commitment to full equality. ${ }^{348}$

In the face of a new racial caste system, the Buffalo Soldiers maintained the old tradition of violent black resistance. If a lynch mob targeted anyone in the four Buffalo Soldier regiments, guilty white communities could expect swift and severe retribution. In an era during which black citizenship rights contracted, some African Americans believed that overt action was needed more than ever to finally establish racial equality in U.S. society. It was in this disturbing context that members of the Ninth Cavalry threatened to unleash a Haitian-style black insurrection on the town of Crawford, Nebraska, after one of their comrades almost became another lynching victim.

Not all African Americans during the Jim Crow period agreed with the path chosen by mutineers and rioters. Black Lt. John H. Alexander took an accommodationist approach towards racism in the Army. To avoid any possible conflict, he merely declined invitations to dine with white officers. He received praise and recognition as a "manly" and "courteous" officer for performing his duty in this manner. For him, to challenge racism was "painful" and "fruitless." 349 Despite the accommodationist choice of some, other African Americans emerged from the Spanish-American and Philippine-American Wars even less tolerant of white racism. While earlier African-American troops knew slavery firsthand, the black men growing up after bondage's death had reached adulthood. This new generation had helped secure the West and pursued opportunities offered by the era's industrializing, urbanizing economy. When war in the

\footnotetext{
${ }^{348}$ Glenda Gilmore, Gender and Jim Crow; Omar H. Ali, In the Balance of Power: Independent Black Politics and Third-Party Movements in the United States (Athens: Ohio University Press, 2008), 99; Stephen Hahn, A Nation Under Our Feet Black, 465-476; Booker T. Washington, "The Atlanta Compromise," September 18, 1895; W.E.B. Du Bois, "Of Booker T. Washington and Others," The Souls of Black Folk (Chicago: A. C. McClurg and Co., 1903), 41-59; William D. Carrigan, The Making of a Lynching Culture: Violence and Vigilantism in Central Texas, 18361916 (Champaign, IL: University of Illinois Press, 2006); Amy Louise Wood, Lynching and Spectacle: Witnessing Racial Violence in America, 1890-1940 (Chapel Hill: University of North Carolina Press, 2011).

${ }^{349}$ Crawford Tribune, April 6, 1894, Orders No. 20, March 30, 1894, RG 391, NARA, quoted in Ibid., 200-203.
} 
Caribbean and west Pacific broke out, African Americans in general and the Buffalo Soldiers in particular were among the surge of recruits. During their service, these black troops earned thirty-six medals, including six Medals of Honor, and enjoyed laudatory attention from journalists and commanders. They won distinction especially for helping Teddy Roosevelt's Rough Riders win battles and capturing Spanish positions under heavy fire. The white poet B. M. Channing captured the praise even racists gave black soldiers when he wrote a poem about the Tenth Cavalry: “We used to think the negro didn't count for very much/ But we've got to reconstruct our views on color...Read the story of his courage/ The story of the Tenth at La Quasina!” According to this poem, black men had met all requirements for racial equality. ${ }^{350}$ Yet, black troops returning from the conflicts of 1898-1902 found their hopes for greater acceptance and expanded rights as a reward for their service dashed, causing the first two decades of the twentieth century to be characterized by acute racial tensions that eventually reached a boiling point. Despite African-American sacrifices on battlefields for thirty years, white civilians continued to oppose the stationing of black forces in and around their communities. Throughout the country, episodes of racial violence increased qualitatively and quantitatively in the early twentieth century. Buffalo Soldiers had long waged their own war against racism, but the unique climate of Jim Crow and international military intervention added extra doses of impatience, solidarity, and assertiveness. Though a dark period in U.S. race relations, as Garna Christian describes it, this was also "a story of loft aspiration too long

\footnotetext{
${ }^{350}$ B. M. Channing, "The Negro Soldier," Boston Journal, quoted in James Henry Brownlee, War-time Echoes: Patriotic Poems, Heroic and Pathetic, Humorous and Dialectic of the Spanish-American War (Akron, OH: The Werner Company, 1898), 129-130. Among the most thorough contemporary accounts of the black contributions to the Spanish-American War came from T. G. Steward, the Twenty-fifth Infantry's chaplain. See T. G. Steward, The Colored Regulars in the United States Army (Philadelphia: A.M.E. Book Concern, 1904). He thought it fitting that his unit of well -disciplined black soldiers was "called first to the front in a war against oppression." Ibid., 96.
} 
delayed, of the transformation of an obsequious race into a self-confident people, and the righteous attempt, sometimes mistaken in its approach, to realize the American Dream." 351

The Brownsville Affair of August 1906 reveals that as the country plunged deeper into the Jim Crow era, white supremacy became more pervasive in the Army. No longer the relative bastion of black legal rights that it had been since the Civil War, the branch began engaging in just as great, if not greater, acts of injustice than civilian society. That their superiors now assumed them to be guilty, no matter how weak the evidence, revealed that the emancipation process was in free fall. The Twenty-fifth U.S. Infantry regiment learned this painful lesson.

After serving with distinction in the Cuban and Philippine conflicts, over the next couple years, the Twenty-fifth resumed peacetime duties at western garrisons. They initially received rare positive media coverage. While stationed in Nebraska for a rifle competition in the summer of 1904, a local paper complimented these troops as "the better class of their race," men who proved themselves less prone to "disturbance and noise" than white soldiers. Following the closure of the Nebraska garrison, Companies B, C, and D replaced the white Twenty-sixth Infantry at Fort Brown in Brownsville, Texas, along the U.S.-Mexican border and Gulf Coast. ${ }^{352}$

Despite a warm welcome in Nebraska, when the Twenty-fifth entered southeastern Texas, all-too-familiar mistreatment awaited it. Brownsville's white residents sent protests to the War Department, which Secretary William H. Taft ignored. After arriving, soldiers received racial slurs and accusations of violating white womanhood. Policemen assaulted troops for physical contact with white women, intoxication, and verbally questioning segregation laws. As Sergeant Major Vance Marchbanks noted, the presence of armed blacks meant that whites could

\footnotetext{
${ }^{351}$ Garna Christian, Black Soldiers in Jim Crow Texas, xvi; Frank Schubert, Voices of the Buffalo Soldier, 31-32, 114-122; The African-American Experience in Texas, eds., Bruce Glasrud and James Smallwood.

${ }^{352}$ Garna Christian, Black Soldiers in Jim Crow Texas, 69-72.
} 
not "carry out their favorite sport"-lynching - causing them to lash out at this challenge to the South's racial code. On the night of August 13, nine to twenty unidentified men discharged several hundred bullets near the fort's walls and towards the lit portions of the town. The tenminute attack killed a bartender and wounded a policeman and a book editor. Fort Brown's officers immediately conducted a roll call, which found every enlisted man present. ${ }^{353}$

Two narratives developed regarding the incident. One arose from the town, which Army commanders and the government endorsed; another came from the enlisted men. The white citizenry immediately assumed the men of the Twenty-fifth Infantry were the raiders. They cited the following evidence: claimed sightings, the similarity between the sounds of the shots in the raid and those made by the Army's Springfield rifles, and the racial tensions leading up to the act. However, no witness could identify a single suspect. According to sentinel guard Private Joseph Howard and post scavenger Matias Tamayo, the shots came from outside their garrison. These two, plus Major Penrose, assumed a white mob was attacking them. Commissioned and noncommissioned officers confirmed that the men's weapons had not been recently used. Yet, the city found cartridges on the scene, which persuaded Major Penrose of the troops' guilt. The alarmed community and Texas' senators pleaded for the government to replace the black troops with white ones. Steeped in conservative racial views, the press deemed the raid's motive as retaliation against mistreatment and discrimination. A Roosevelt administration investigation refused to condemn the chronic police brutality against the black soldiers. Placing the incident in the context of African-American vigilance against Jim Crow, it further noted that "the colored soldier is much more aggressive in his attitude on the social equality question than he used to

\footnotetext{
${ }^{353}$ Ibid., 72; Letter from Vance Marchbanks, The Voice, December 1906, 549, transcribed in William Loren Katz, The Black West: A Documentary and Pictorial History of the African American Role in the Westward Expansion of the United States (New York: Doubleday, 1971), 208 (quote).
} 
be." One Army chaplain captured a familiar theme in the history of black resistance in the U.S. Army, acknowledging that since "the soldiers could get no redress...they shot up the town." Meanwhile, in their counter-narrative, the accused maintained their innocence their entire lives. ${ }^{354}$

The experience of those allegedly involved in the Brownsville incident in the civilian and military criminal justice systems constituted a reversal of how the two tended to operate. Despite the lack of evidence, Texas Rangers arrested twelve garrison soldiers. Honoring the desire of white Brownsvillians, President Teddy Roosevelt ordered the suspects moved to Fort Sam Houston to await civil prosecution and the rest of the First Battalion to Fort Reno, Oklahoma. While the judge in the case described them as people with "hearts blacker than their skins," the grand jury failed to indict the men following a three-week civil investigation. For a white grand jury in the Jim Crow era to exonerate black suspects was extraordinary, a testament to the sheer dearth of evidence. However, the U.S. high command was determined to punish them; the twelve suspects remained in Army custody. The president sent War Department Inspector General Ernest Garlington to the forts. If he could not persuade the men to identify guilty parties, "orders will be issued...discharging every man in Companies B, C, and D [First Battalion], without honor." The men refused to cooperate. The inspector general observed that the men "stand together in a determination to resist the detection of the guilty." The federal government thus weaponized these soldiers' solidarity against them. On November 4, Roosevelt followed through on his dismissal threat. One hundred and sixty-seven men returned to civilian life in shame. ${ }^{355}$

\footnotetext{
${ }^{354}$ Garna Christian, Black Soldiers in Jim Crow Texas, $72-77$ (first quote); Senate Committee on Military Affairs, "Affray at Brownsville, Tex," in Summary Discharge or Mustering out of Regiments or Companies (Washington, D.C.: Government Printing Office, 1908), 220 (second quote); Brownsville Herald, September 11, 1906, https://www.newspapers.com/newspage/71060069/ (fourth quote).

355 “Judge Welch's Charge to the Grand Jury," in Senate Documents, Vol. 23, 60 ${ }^{\text {th }}$ Cong., $1^{\text {st }}$ Sess. (Washington, D.C.: GPO, 1908), 3297 (first quote); Senate, Report of the Proceedings of the Court of Inquiry Relative to the Shooting Affray at Brownsville, Tex., August 13-14, 1906 by Soldiers of Companies B, C, and D Twenty-fifth United
} 
The national response to the controversial decision highlighted the social and political concerns of African Americans and their white allies during the turn of the century. African Americans nationwide responded with outrage. The Atlanta Independent captured black sentiments when it proclaimed the dismissal a "flagrant violation of our constitutional rights" comparable to "lynch-law." The Colored American Magazine published the following poem honoring the dismissed soldiers' refusal to betray their comrades: "Now tell who did the shooting And how it all begun'/ But not one word escaped their lips/ That noble band stood mum/ You are discharged, every man of you, Dishonored and disgraced. Ah, but who can say dishonor/ When men stand by their comrades For the protection of their life." Participants in the backlash reminded Roosevelt that his occupation of the White House resulted from the service of Spanish-American War troops of African descent. They also lambasted Secretary Taft for assisting white soldiers who fired on Athens, Ohio, in 1904 for non-racial motivations but refusing to do the same for the black troops of Brownsville in 1906. A Senate Military Affairs Committee demanded justification for the president punishing soldiers absent a trial. However, a majority of the senators agreed with the decision. Attempting to appease critics, Roosevelt allowed the dismissed men to appeal for reenlistment and reopened them to civil service employment. In early 1910, the War Department only permitted fourteen soldiers to re-enlist. ${ }^{356}$

States Infantry, Vol. 10, 106 ${ }^{\text {th }}$ Cong. $3^{\text {rd }}$ Sess. (Washington, D.C.: GPO, 1911), 2268 (second quote); Report from Inspector General Garlington, quoted in “A Just Act,” December 1, 1906, New Outlook, Volume 84 (third quote); Garna Christian, Black Soldiers in Jim Crow Texas, 77-80.

${ }^{356}$ Atlanta Independent, November 17, 1906, quoted in Lewis N. Wynne, "Brownsville: The Reaction of the Negro Press," Phylon, Vol. 33, No. 2 (1972), pp. 153-160 (first quote); The Colored American Magazine, January 1907, pp. 62-63 (second quote); Garna Christian, Black Troops in Jim Crow Texas, 80-84; U.S. Senate, Committee on Military Affairs, Affray at Brownsville, Tex.: Hearings (Washington: GPO, 1907); Senate Documents, Vol. 19, 60 ${ }^{\text {th }}$ Cong., $1^{\text {st }}$ Sess. (Washington, D.C.: GPO, 1908). For the white Ohio riot, the function of a bitter rivalry between the National Guard and Army regulars, see Cyrus Moore III, The Athens Maneuvers: The Ohio National Guard Maneuvers in Athens County, August 17-23, 1904 and the Remaking of the Guard (Athens, Ohio: Athens County Historical Society and Museum, 2012). Meanwhile, Booker T. Washington, champion of accommodation, was the sole black leader who refused to criticize the president, deeming such a course counterproductive for black rights. 
The troops involved kept the memory of the incident alive. Dorsie Willis, the last surviving discharged soldier, remarked in 1972 on why they went silent afterward. He explained that "None of us said anything because we didn't have anything to say. It was a frameup through and through." The rhetoric decrying the president's order persisted into the civil rights era. ${ }^{357}$

Until the civil rights movement, historians generally agreed with the town's interpretation of the Brownsville affair. Yet, since the early 1970s, scholarship and public opinion has vindicated the First Battalion. This shift in opinion led to President Richard Nixon and Congress agreeing to convert the discharges into honorable ones and to grant a pension to Willis. The latest scholarly consensus holds that the Army's treatment of the Brownsville soldiers was arbitrary and a function of the country's dominant white supremacist culture. ${ }^{358}$

Beyond the legal injustice itself, the story of Dorsie Willis allows one to more fully examine the setback this discharge inflicted on blacks' long-term struggle for the full implementation of their emancipation. Growing up in a sharecropper family, Willis exemplified how many black men used military service for their own uplift from a socioeconomic arrangement that mocked their free status. As all convicted mutineers, proven and unproven alike, learned afterward, the dishonorable discharge from the military upset their material wellbeing, forcing them to perform menial jobs for the rest of their lives. While Willis eventually won a $\$ 25,000$ settlement decades later, it was too little, too late for the former soldier, who at age eighty-eight continued to shine shoes in a Minneapolis barbershop. Willis reflected on the damage his dismissal did to him. Believing that the "world owed me an opportunity to earn a

\footnotetext{
${ }^{357}$ New York Times, September 29, 1972, quoted in Garna Christian, Black Troops in Jim Crow Texas, 86.

358 John D. Weaver, The Brownsville Raid (New York: W. W. Norton and Company, 1970); Ann J. Lane, The Brownsville Affair: National Crisis and Black Reaction (Port Washington, New York: Kennikat Press, 1971); Garna Christian, Black Troops in Jim Crow Texas, 84-87. For more on Senator Foraker's campaign to secure justice for the Brownsville soldiers, see John D. Weaver, The Senator and the Sharecropper's Son: Exoneration of the Brownsville Soldiers (College Station, Texas A\&M University Press, 1997).
} 
living," the discharge "kept me from improving my life." A half century after the USCTs helped destroy slavery, the dream of economic independence remained elusive for African Americans living in a white supremacist society, whether they committed a revolt or not. ${ }^{359}$

Regardless of their guilt level, every member in the First Battalion exhibited a commitment to preventing a single comrade from suffering the shame and harm of prosecution. Depending on what really happened that summer night, they protected the right of comrades to possess enough due process protections to avoid becoming a scapegoat. Such an action exposed how greatly the Buffalo Soldiers, at least in the Twenty-fifth, had become a united front since the Fort Stockton mutiny thirty years prior. The coordination this group displayed was non-mutinous in nature, but the determination to risk one's own livelihood to avoid collaborating in someone else's civil rights violation mirrors the disregard mutineers had for their lives. The government's decision to convict them via executive, not judicial, action, illustrated the extent to which the emancipation process regressed at this time. That black due process rights lost enforcement in the Army, where black servicemen traditionally enjoyed greater legal protection than did civilian counterparts, mirrors the parallel reduction in black civil rights in the country, especially the South, generally. These trends demonstrate the influence society had on the military it birthed. ${ }^{360}$

\footnotetext{
359 John D. Weaver, The Senator and the Sharecropper's Son, xii-xvi, 212-213 (quotes).

${ }^{360}$ A supposed act of revenge for the mass dismissal in late 1906 presented a sequel to this narrative of racial violence, unclear happenings, and questionable implementation of justice. While the regiment was stationed in Fort Reno, Oklahoma, on the evening of December 21, 1906, someone in military clothing and a covered face attempted an armed robbery of post funds at the home of Captain Macklin, who had slept through the summer affair. After injuring Macklin, the perpetrator promptly fled. Most observers used the assailant's military clothing and knowledge of post funds to claim that he was one of the Brownsville raiders. Once again, everyone was present in a subsequent roll call. Two brothers discovered an Army jacket floating in a nearby creek with insignia removed and containing five cartridges, a blood stain, and the initials E. L. K. The finding led to the arrest of Corporal Edward L. Knowles. Despite his presence at roll call, a court-martial ruled him guilty of attempted murder and theft, despite Macklin's inability at trial to either positively recognize the defendant or establish previous association. As a member of Company A, Corporal Knowles was never stationed at Fort Brown. The court dishonorably discharged Knowles and sentenced him to fifteen years of hard labor. See Garna Christian, Black Soldiers in Jim Crow Texas, 87-91.
} 
The decades-long trends of the Buffalo Soldiers mutinying against reviled officers, combating antagonistic white civilians, becoming ever more organized in their resistance methods, and serving amidst their country's transition from Redemption to Jim Crow climaxed in the single most violent case of African-American soldier resistance to white supremacy: the Houston Riot of 1917. On the dark, rainy night of August 23 and early morning of August 24, members of the Twenty-fourth U.S. Infantry's Third Battalion engaged in actions that contained elements of both a mutiny and a race riot, blurring the boundary between two similar types of rebellion that had served identical goals. ${ }^{361}$ This bloody affair can only be fully understood in the context of the black regulars' entire history of conflict with white mistreatment.

The sheer scope of brutality featured in Houston has made the event the most famous single rebellion in Buffalo Soldier historiography. It was not until the publication of works by Arthur Barbeau, Florette Henri, and Robert Haynes in the 1970s that scholarship treated the revolt less sensationally than the journalists who initially reported on it. According to the older view, the mutineers implemented a conspiracy to enact revenge that used the fear of a white mob as a bogus excuse. C. Calvin Smith's recent reading of the riot's documentation counters that the event constituted a spontaneous reaction to weeks of white supremacist verbal and physical abuse and a valid fear of racial mob violence, a view articulated by the men's defense during their court-martial. Branching out temporally, Garna L. Christian's 1995 monograph links the 1917 Houston Riot and earlier episodes of racial violence in Texas. ${ }^{362}$

\footnotetext{
${ }^{361}$ For more on the difference between a racially motivated mutiny and a race riot, see the introduction chapter.

362 Arthur E. Barbeau and Florette Henri The Unknown Soldiers: African-American Troops in World War I (Philadelphia: Temple University Press, 1974); Robert V. Haynes, A Night of Violence: The Houston Riot of 1917 (Baton Rouge: Louisiana State University Press, 1976); C. Calvin Smith, "The Houston Riot of 1917, Revisited," in Buffalo Soldiers in the West, eds., Bruce Glasrud and Michael Searles, 202; Garna L. Christian, Black Soldiers in Jim Crow Texas.
} 
A fresher look at the evidence merges and revises in part the arguments of Smith and Christian while also stretching the event's origins earlier, into the Buffalo Soldiers' nineteenthcentury founding. As the current work has shown, African-American troops across several decades chose to rebel under circumstances that the Twenty-fourth stationed near Houston in the late summer of 1917 would have found familiar: after weeks or months of miseries plaguing troops' lives, long-festering animosities exploded. They indeed were spontaneously responding to worries of white mob violence in self-defense, but the often indiscriminatory targeting of white citizens and stated desires to avenge a slain comrade suggest that an element of organized retribution existed. This is especially so considering that vengeance was a factor that repeatedly drove previous Buffalo Soldiers to shoot up a location that harmed a comrade.

Examining an African-American soldier revolt during the First World War builds upon recent scholarship highlighting the connection long neglected in the historiography between the conflict and the black freedom struggle. The experience of the conflict repeated lessons from previous wars. In the follow up to the U.S. entry into World War I, African-American leaders again hoped that black military service would finally convince white America to endorse their emancipationist vision of a biracial democracy that recognized blacks' manhood and worthiness for citizenship. Yet, the arrival of armed, proud black men demanding equality sparked yet another backlash from the upholders of the racial caste system. The Great Migration of rural black southerners to northern cities in pursuit of higher-paying industry jobs led to white neighbors attacking black workers and banning them from unions. Southern congressmen sponsored legislation that would have blocked black enlistment. While Secretary of War Newton D. Baker defeated this effort, the American Expeditionary Force (AEF) confined most black troops to non-combat labor roles such as burial duty and unloading ships. Barred from fighting 
the Kaiser, those stationed stateside instead confronted their top domestic enemy, Jim Crow. To prevent the certainty of racial tensions resulting from stationing black troops in the South, the Army's high command decided against placing them there. However, Baker reversed this course, citing his philosophy that the War Department had no responsibility to settle the "race question," instead advising units to use "discretion and judgement" to minimize problems. The policy's failure to prevent the riot confirmed the initial fears among the high brass. Still committed to white supremacy, mainstream society ignored blacks' contributions to the war effort, leading two scholars to label these members of the "lost generation" as the "unknown soldiers." The dashing of the latest hopes for a full emancipation made black mutinies likely in Great War America. ${ }^{363}$

The racial problems in Houston began when the unit's six hundred forty-five men relocated from New Mexico on July 28, 1917, to guard an ongoing construction project at Camp Logan, just west of the city. The men's superiors sent them into an area that staunchly opposed their mere presence, expected their subservience, and refused to assist black military police. Such circumstances clashed with the pride and militance black men developed while serving in the Army since the Civil War. Black Houstonians were fully aware of what awaited the Twentyfourth. This included the physician who once told the NAACP that he wondered whether he was leaving home for the last time every time he stepped outside, or the minister who attested to how "law abiding citizens feared the police in getting over the city at night more than they feared the highwaymen." These black troops in particular had grown accustomed to relatively better treatment outside the Lone Star State, giving them heightened expectations for how American

\footnotetext{
${ }^{363}$ Chad L. Williams, Torchbearers of Democracy: African American Soldiers in the World War I Era (Chapel Hill: University of North Carolina Press, 2010); Stephen Hahn, A Nation Under Our Feet; C. Calvin Smith, "The Houston Riot of 1917, Revisited," in Buffalo Soldiers in the West, eds., Bruce Glasrud and Michael Searles, $197-$ 199, 210-211 (quote on 211); Garna Christian, Black Soldiers in Jim Crow Texas, 128; Bernard C. Nalty, Strength for the Fight: A History of Black Americans in the Military (Free Press, 1986); Arthur E. Barbeau and Florette Henri, The Unknown Soldiers. Among black units during the Great War, only the Ninety-third Infantry Division enjoyed sufficient training and leadership to perform with distinction on French battlefields.
} 
society should treat them. In the month between the battalion's move to Houston and the riot, numerous verbal and physical altercations broke out between black soldiers asserting their equality and white construction workers and policemen who resorted to the same brutal coercion used against black civilians who challenged the color line. A common trigger for clashes was the white use of the "nigger" epithet towards soldiers, who retaliated with profane outbursts. ${ }^{364}$

The Houston Riot/Mutiny also took place in a context of upheaval in the Twenty-fourth Infantry's command structure. On August 21, the Army swapped the men's colonel of two years for an inexperienced major who appeared more concerned with leisurely activities than his men's well-being. Incredibly, dozens of experienced officers were absent training in Iowa. C. Calvin Smith is correct in attributing these misguided personnel decisions as a contributing factor to the mutiny, a decision that clearly ignored Secretary Baker's "discretion and judgement" order. At a time when African Americans were struggling to cope with Jim Crow's injustices and using military service to try to improve their socio-political standing, the Twenty-fourth's mutinous battalion entered an environment with a more stringent and violently-enforced racial code than what they had been used to, all without the stability provided by their familiar officers. ${ }^{365}$ As this situation illustrates, the Lone Star State maintained its reputation as particularly hostile to African-American military personnel. Company K's captain remarked that "Every time

\footnotetext{
364 "Negro Soldiers on Trial for Mutiny at Houston Aug. 23," November 2, 1917, Houston Daily Post, Harry S. and James L. Grier Papers, Box 3, U.S. Army Heritage and Education Center (USAHEC), Carlisle, Pennsylvania; "Evidence Against Mutinous Negroes Shows Their Guilt," November 15, 1917, Ibid.; Garna L. Christian, Black Soldiers in Jim Crow Texas; Proceedings of GCM, Trial of Robert Tillman et. al., Case No. 114575, RG 153 and 393, NARA, http://cdm16035.contentdm.oclc.org/cdm/singleitem/collection/p15568coll1/id/2070/rec/4; "All Sides Agree on Causes Leading to Riot of Troops," November 2, 1917, San Antonio Express, Harry S. and James L. Grier Papers, Box 3, USAHEC; Martha Gruening, "Houston: An N.A.A.C.P. Investigation," W.E.B. Du Bois, ed., The Crisis: A Record of the Darker Races Vol. 15 (November 1917): 19 (quote).

${ }^{365}$ C. Calvin Smith, "The Houston Riot of 1917, Revisited," in Buffalo Soldiers in the West, eds., Bruce Glasrud and Michael Searles, 210; Proceedings of a GCM, Trial of William Nesbit, et. al., RG 153 and 393, NARA, http://cdm16035.contentdm.oclc.org/cdm/singleitem/collection/p15568coll1/id/2058/rec/16; Proceedings of GCM, Trial of Robert Tillman et. al., Case No. 114575, RG 153 and 393, NARA, http://cdm16035.contentdm.oclc.org/cdm/singleitem/collection/p15568coll1/id/2070/rec/4.
} 
we have been in Texas we have had trouble." Sergeant Cecil Green and his comrades predicted a continuation of this trouble "in Houston from [white] mobs." Battalion commander William Newman wishfully hoped to forestall violence by ordering nearly everyone to disarm. Racial bloodshed was on the horizon the moment the Twenty-fourth arrived in a Jim Crow city. ${ }^{366}$

The ordeals of late summer 1917 culminated in the latest example of racially-motivated police brutality. At 10:30 a.m. on the day of the insurrection, two city policemen, Lee Sparks and R. H. Daniels, raided a craps game played by several black children and slapped and arrested a black woman who sheltered the kids. For interfering with these apprehensions, Officer Sparks beat and placed Private Alonzo Edwards into custody. Sparks stood out on the Houston police force as a sadist fond of violently reminding African Americans of their inferior social status. ${ }^{367}$

That afternoon, Corporal Charles W. Baltimore, a twenty-three-year-old native Pennsylvanian serving on the camp's military police force, asked the two civilian policemen on San Filipe for the reason they arrested his comrade. While serving as a character witness in the resulting court-martial, Major K. S. Snow described Corporal Baltimore as a "very good man" who had received a recommendation to attend a black officers' training camp. His fateful incident with Jim Crow justice pulled him into a path that ended his career advancement and shiny reputation. In response to the corporal's comment that "I'm on duty on this beat and when I return to camp I must report," Sparks proclaimed he “don't have to report to any nigger." The officials then pistol-whipped Baltimore's head three times before jailing him. Battalion officers returned the injured corporal to camp by the late afternoon. Houston police chief Brock

\footnotetext{
${ }^{366}$ Quoted in C. Calvin Smith, “The Houston Riot of 1917, Revisited," in Buffalo Soldiers in the West, eds., Bruce Glasrud and Michael Searles,199-200. To economically benefit from the war effort, the Chamber of Commerce promised the War Department that Houston would greet the unit "in a spirit of patriotism."

${ }^{367}$ For a preview of what was to come in Houston that occurred in nearby Waco a month prior, see Garna Christian, Black Soldiers in Jim Crow Texas, 128-144.
} 
suspended Sparks, knowing that any jury would exonerate him. News of the incident soon reached the Third Battalion's camp, producing false reports that the police had shot and killed Baltimore. According to witness recollections, in the hours leading up to the mutiny, the perpetrators advised "their girls" against visiting camp that night, suggesting they were plotting violence. Troops verbally planned to march to the city to "raise hell" and kill every white civilian and policeman they encountered, since "they were not going to stand for it (abuse)." After a month of frustration over mistreatment from white Houstonians, members of the Twenty-fourth had finally had enough; that Baltimore survived his own attack did not matter. ${ }^{368}$

What began as a series of reports, rumors, and discussions quickly morphed into a tempest of flying metal and blood. Major Kneeland Snow, Lieutenant Charles C. Snyder, and Captain Haig Shekerjian attempted to diffuse the situation by banning men from leaving camp, assuring them that Baltimore still lived, and informing them of Sparks' suspension. Yet, the situation escaped the control of the commissioned officer corps. ${ }^{369}$

The men became visibly restless, forming crowds in the company streets. They not only feared another white attack, but also assumed that their commanders' disarmament order had the intention of preventing them from defending themselves. In response to rumors that a civilian mob was approaching, various noncommissioned officers and members of the rank-and-file charged toward supply tents, seizing weapons and ammunition rounds at around 7:30. Sergeant Vidal Henry reportedly commanded the men to hurry, conserve ammunition, fill their canteens,

\footnotetext{
368 "Defense Rested Courtmartial at San Antonio," November 23, 1917, Houston Daily Post, Harry S. and James L. Grier Papers, Box 3, USAHEC; "Negro Soldiers on Trial for Mutiny at Houston Aug. 23," November 2, 1917, Ibid.; "Capt. Shekerjian Described Mutiny of Negro Soldiers," November 3, 1917, Ibid.; "Participants in Houston Mutiny to Give Evidence," November 13, 1917, Ibid.; "Corporal Baltimore Boasted of Killing Policeman Daniels," November 14, 1917, Ibid.; Prisoner file of Charles W. Baltimore, 1918, Office of the Judge Advocate General, RG 153 and 393, NARA, http://cdm16035.contentdm.oclc.org/cdm/ref/collection/p15568coll1/id/2103. 369 "Capt. Shekerjian Described Mutiny of Negro Soldiers," November 3, 1917, Houston Daily Post, Harry S. and James L. Grier Papers, Box 3, USAHEC; "Attack on Houston By Negro Soldiers Is Told By Victims," November 5, 1917, Ibid.; "Evidence Against Mutinous Negroes Shows Their Guilt,” November 15, 1917, Ibid.
} 
and form a battle line. Contending that "we're tired of seeing the soldiers beaten up," those arming themselves wanted to "take the law into our hands." Members of the group asked their commander, "Major, what are we going to do when they beat us over the head like that?" Snow replied that the protocol was for them to report such abuses to him. The major testified that a crowd of between twenty-five and thirty on the company street excitedly threatened to shoot or "bore" him if he took another step forward. Snow's orders to disarm and warnings fell on deaf ears. As the mutinous crowd started becoming agitated, Lt. Snyder and Captain Shekerjian issued orders to "take in rifles and fall in," as well as for the placement of guards around supply tents. Fifty-two men of Company K complied. However, a number, including McWhorter, Burkett, New, T. Jackson, and Walter Johnson, refused to put their rifles down. A corporal tasked with guarding the supply tents notified a lieutenant that "it looked like a mutiny" was forming. The mutineers' anger steadily intensified to the point that they accompanied their death threats with rifles pointed at their battalion commander. Feeling his life now in danger, Major Snow rushed to the other end of the fort to gather a suppression force. Witnesses suddenly and repeatedly heard the declarations "Here comes the mob!" and "Here they come" from men in all three companies, including Sgt. Vidal Henry, Frank Johnson, and Pvt. James Divine. ${ }^{370}$

At this moment came the breaking point, when Company I's Private Frank Johnson discharged his weapon. The rest of the mutineers opened fire in multiple directions between 8:00 and 8:30 pm, creating a chaotic scene in which other soldiers ran for cover. The terrified shooters, blinded by the night and deafened by their barrage, accidently wounded several comrades and killed one. Next, Privates Kane, Wardlow, and Taylor declared, "Let's go and get

\footnotetext{
370 "Negro Soldiers on Trial for Mutiny at Houston Aug. 23," November 2, 1917, Ibid.; "Capt. Shekerjian Described Mutiny of Negro Soldiers," November 3, 1917, Ibid.; "Here Comes the Mob Seems to Have Been Signal For Mutiny," November 4, 1917, Ibid.
} 
the man than shot Corporal Baltimore." Witnesses identified Sergeant Henry as the main ringleader, with the following performing secondary leading roles: Corporals Baltimore, Wheatley, Brown, and Moore; and Privates Pat McWhorter, Risley Young, and Frank Johnson. A second-generation soldier, Henry had served in the Army for thirteen years, during which he developed a reputation for discipline. Wheatley, Brown, and Moore stated their intention to "go downtown" and "shoot up the town." Prioritizing keeping their local surroundings, rather than the world, safe for democracy, mutineers also shouted, "To hell with going to France. Let's clean up the __ city." Demonstrating the legacy of Buffalo Soldier resistance to white supremacy, a mutineer contended that "if it had been the $9^{\text {th }}$ or $10^{\text {th }}$ cavalry they would be already going." After shooting for between five and fifteen minutes, the hundred mutineers headed to Houston. Snow proceeded to warn the city of the attack. ${ }^{371}$

The comment regarding how the Buffalo Soldiers' cavalry wing would have responded to these circumstances gives us an insight into the black regulars' inter-unit relations. While it is otherwise unclear from the record what reputations the cavalry regiments enjoyed in the infantry, the Twenty-fourth's members likely had knowledge that the Ninth and Tenth repeatedly rebelled against white supremacy in earlier decades. The Houston episode served as the Twenty-fourth Infantry's first revolt, while the Twenty-fifth Infantry had previously conducted two, one of which lacked solid evidence tying the unit to it, the Brownsville Raid. When taken together, by contrast, between 1867 and 1898, both cavalry units had nine mutinies or race riots under their belt. Perhaps in the depths of the despair these foot soldiers felt under the weight of Jim Crow,

\footnotetext{
371 “Corporal Baltimore Boasted of Killing Policeman Daniels," November 14, 1917, Ibid.; "Evidence Against Mutinous Negroes Shows Their Guilt," November 15, 1917, Ibid.; "Self-Confessed Riot Participant Identified Many," November 17, 1917, Ibid.; C. Calvin Smith, "The Houston Riot of 1917, Revisited," in Buffalo Soldiers in the West, eds., Bruce Glasrud and Michael Searles, 204-205.
} 
they concluded they needed to live up to their horse-riding comrades' historical devotion to the tradition of martial manhood and black resistance in service of their race's freedom.

Continuing a trend dating back to the first black Army mutinies, these Buffalo Soldiers of 1917 peer pressured the non-mutinous. Private Frank Draper later testified that as the mutineers departed from camp to attack Houston, each one asked him “Come on; ain’t you going?" Mutineers appealed to racial solidarity: "Let's go stick by your race." When a bugler complied with an order to play the "cease fire" sound, a mutineer snapped, "If you do not take that trumpet out of your mouth I'll shoot it out." Out of a desire for self-protection, Draper refused to surrender his rifle until being ordered a second time and Pvt. John Denty waited to report the formation of the mutinous group instead of immediately, as required by Army law. ${ }^{372}$

A second, more severe storm of gunfire and bloodshed hit Houston into the early morning hours. Between seventy and one hundred and fifty men of the Twenty-fourth Infantry crossed the knee-deep Buffalo Bayou and marched on San Filipe Street across Houston's white business district. Moving in military formation, the mutineers fired at white homes, individuals, and vehicles while sparing African Americans and whites who sheltered blacks.

Though commanded by a corporal committed to military order, and accused by whites of crafting an intricate conspiracy, the men's march through Houston contained elements of a rampage with random targets. This adds weight to the argument that the mutiny was solely a spontaneous action, but Henry's attempts at keeping the body of troops organized and continuing

\footnotetext{
372 "Capt. Shekerjian Described Mutiny of Negro Soldiers," November 3, 1917, Houston Daily Post, Harry S. and James L. Grier Papers, Box 3, USAHEC; "Here Comes the Mob Seems to Have Been Signal For Mutiny," November 4, 1917, Ibid.; "Corporal Baltimore Boasted of Killing Policeman Daniels," November 14, 1917, Ibid.; "Evidence Against Mutinous Negroes Shows Their Guilt," November 15, 1917, Ibid.; "Negroes Tried to Prove They Had No Part in Murders," November 19, 1917, Ibid.; Proceedings of a GCM, Trial of William Nesbit, et. al., RG 153 and 393, NARA, http://cdm16035.contentdm.oclc.org/cdm/singleitem/collection/p15568coll1/id/2058/rec/16; Proceedings of GCM, Trial of Robert Tillman et. al., Case No. 114575, RG 153 and 393, NARA, http://cdm16035.contentdm.oclc.org/cdm/singleitem/collection/p15568coll1/id/2070/rec/4.
} 
to recognize these men's acutely frustrated state of mind confirms that the city assault constituted an act of revenge planned in the short-term. Sergeant Henry, along with Harrison Capers, issued orders to fire. During the carnage, numerous white civilian men, women, and children suffered minor and fatal wounds and a multitude of buildings, vehicles, and trees sustained bullet holes. Teenager Mary Winkler testified that when her family observed the invading Buffalo Soldiers passing next to their home, they said "There they are" and fired, blowing off her brother's arm. Other statements quoted by witnesses proving vengeful desires included 'Let's show the white folks what we're made of," "Let's get the white trash in their shacks," and "We're going to take care of this ___ _ town tonight." Leaving one's lights off increased the chances that the soldiers would spare a house. Other civilians were shot while riding in an automobile, an ambulance, on horseback, or on the San Filipe Street car line. Authorities found two corpses with multiple bayonet wounds, as well as the slain jitney driver E. M. Jones' nearly-severed arm. As the raiders marched by, a number of black civilians cheered and shook their hands. ${ }^{373}$

Authorities launched a riot call. Eight hundred militiamen and six hundred Illinois troops arrived to quell the revolt. Commanding General Haden placed the city under martial law. Furthermore, these white soldiers excavated ammunition and weapons that the mutineers had buried under dirt or wood. Police forces also entered the scene. ${ }^{374}$

The mutineers battled these counter-mutiny forces. At one point, at least a dozen troops intercepted a police car and disarmed its occupants. The band proceeded to verbally and physically assault these enforcers of Jim Crow's sanctioned white supremacist violence. A

\footnotetext{
373 "Death to Women were Threats of Houston Rioters," November 14, 1917, San Antonio Express, Harry S. and James L. Grier Papers, Box 3, USAHEC; Proceedings of GCM, Trial of John Washington, et. al., RG 153 and 393 , NARA, http://cdm16035.contentdm.oclc.org/cdm/singleitem/collection/p15568coll1/id/2055/rec/19.

374 "Death to Women were Threats of Houston Rioters," November 14, 1917, unidentified newspaper clipping, Harry S. and James L. Grier Papers, Box 3, USAHEC.
} 
survivor from this group, C. E. Carter, discharged his shotgun at the black soldiers, giving Privates Pat McWhorter, T. Jackson, and Callie Glenn minor buckshot wounds. The fatal stabbings the soldiers inflicted on Officer Ira D. Rainey opened up his insides, while a bullet penetrated his heart. When Captain Mattes of the Second Illinois Field Artillery arrived on this scene along with Private Alpheus Jones of the coast artillery, a police officer, two corporals from the Fifth Texas Infantry, and a civilian named Zimmie Foreman, mutineers fired on their car, wounding the driver, causing it to crash into a store. The troops twice used the exclamation "Stab that ___" when they identified the car's occupants. In the resulting morbid bayonet attack, a witness from across the street "saw the army's officer's (Mattes') head...stabbed to pieces.” Only Jones and Foreman survived this attack. With Officer Lee Sparks unavailable, Corporal Charles Baltimore used the riot to enact deadly vengeance on the other policeman involved, Rufe Daniels. As he boasted, "I didn't get the man who beat me, but I got his partner.",375

As dawn arrived on August 24 and over the next two days, the mutineers ran out of steam, entering civil and Army custody with no resistance and looking exhausted, dirty, and defeated. They likely came to the sobering realization that they would soon face unsurmountable government resistance. Most of those jailed possessed firearms and hundreds of rounds of ammunition. Captured rioters eventually went under the guard of the white Nineteenth U.S. Infantry before marching with the battalion back to Columbus, New Mexico. Either to escape the pain from wounds incurred during the revolt or to avoid the wrath of the criminal justice system, Sergeant Henry committed suicide. In a last act of camaraderie, he said "good-bye" to fellow soldiers. Civilians found the career soldier-turned-mutineer with his Springfield and the back of

${ }^{375}$ Ibid. 
his skull detached. The rebellion ended with fifteen dead whites, of whom four were policemen and two were military personnel, and dozens wounded. Meanwhile, the black raiders lost two. ${ }^{376}$

These black troops' frustrations with the grave harms Jim Crow inflicted drove them to forcibly resist. It did not matter that white policemen had merely beaten a comrade. The anger boiling over from previous incidents and the possibility that the current one proved worse brought them on such a course, as their predecessors had experienced for decades. Due to the removal of their respected officers, when emotions became intense, the men did not trust their replacements' assurances of justice and safety. The Houston Riot illustrates the power of rumors. Just as white supremacists since slavery believed a black insurrection was always around the corner, African Americans' subjection to chronic, severe mistreatment in the era of segregation and lynching made them assume any rumor of white mob violence possessed validity.

Adding insult to injury was the wide gap between expectations and reality. The crushed dreams of finally enjoying greater respect for volunteering to serve their country in uniform exacerbated the bitterness pushing these members of the Twenty-fourth Infantry to defy their officers and kill police and civilians. Over a half century after slavery collapsed, AfricanAmerican soldiers still faced a racial caste system almost as hostile to black men in arms demanding humane treatment as the old order their grandparents overthrew.

\footnotetext{
376 "Prosecution Will Likely Rest Riot Trial Saturday," November 24, 1917, Ibid.; "Negro Soldiers on Trial for Mutiny at Houston Aug. 23," November 2, 1917, Houston Daily Post, Ibid.; "Capt. Shekerjian Described Mutiny of Negro Soldiers," November 3, 1917, Ibid.; "Attack on Houston By Negro Soldiers Is Told By Victims," November 5, 1917, Ibid.; "Silence Reigned as Citizens Told of Bloody Night," November 7, 1917, Ibid.; "Killing of Captain Mattes Related by Wounded Man," "Trail of Negroes who Mutinied is being Established," November 9, 1917, Ibid.; "Houston Policemen Told of Arresting Negro Mutineers," November 11, 1917, Ibid.; "Corporal Baltimore Boasted of Killing Policeman Daniels," November 14, 1917, Ibid.; "Evidence Against Mutinous Negroes Shows Their Guilt," November 15, 1917, Ibid.; "Self-Confessed Riot Participant Identified Many," November 17, 1917, Ibid.; "Interesting Developments Expected in Anderson Trial," November 15, 1917, Ibid.; "Fate of Negroes Who Mutinied is Now with Court," November 26, 1917, Ibid.
} 
The racial consciousness of the mutineers is apparent from the background of their ringleader. Sergeant Henry previously raised funds for the victims of the East St. Louis riots, a white supremacist atrocity. Disgusted with white mob violence, Henry struck back with black mob violence. C. Calvin Smith uses officers' comments on Henry's loyal, polite personality and poor command skills, and the ways in which the prosecution offered black witnesses immunity and asked leading questions, to refute the claim that Henry served as the ringleader. While Smith makes a logical point, black mutineers of all eras were not always preexisting troublemakers; when calm and collected people endure enough psychological strain, they can act uncharacteristically hysterical and vicious. Yet, despite the claims of white contemporaries, no evidence exists that Henry or any other perpetrator organized a premeditated rebellion. ${ }^{377}$

Not just their personal experiences, but also the culture and society in which these men grew up, confirmed the failure of the Civil War and Reconstruction generation to secure its ambitious goals for a more egalitarian American republic. Coupled with an erosion of their socio-political status, they witnessed the progression of a cultural wave that lionized the Lost Cause and sectional reconciliation while forgetting the Civil War's emancipationist legacy. ${ }^{378}$ While preparing to serve their country in a worldwide crusade on behalf of democracy, providing the opportunity to reverse these horrific trends in American race relations, they found themselves forced to confront the top domestic enemy of their U.S. citizenship rights before they could meet the main foreign enemy. As warriors, they took this military campaign to a local outpost of the Jim Crow racial regime that directly attacked their comrades, rather than passively endure it and

\footnotetext{
377 Proceedings of a GCM, Trial of William Nesbit, et. al., RG 153 and 393, NARA, http://cdm16035.contentdm.oclc.org/cdm/singleitem/collection/p15568coll1/id/2058/rec/16; C. Calvin Smith, "The Houston Riot of 1917, Revisited," in Buffalo Soldiers in the West, eds., Bruce Glasrud and Michael Searles, 207. ${ }^{378}$ See David Blight, Race and Reunion: The Civil War in American Memory (Cambridge: Harvard University Press, 2001).
} 
wait to use their soldiering skills on Germans they had never met. The occasional mutilation of the mutineers' targets and the targeting of every white individual they encountered spoke to an intense rage. With this generation of black soldiers seeing their people slide into an oppressive racial caste system and their white officers acquiescing to this order, it is little wonder why one hundred troops reacted so belligerently in Houston in 1917. The mockery Jim Crow made of black freedom revealed that the long emancipation process had regressed to a dangerous level.

Paying a high price for their insurrection, the perpetrators felt the full blow of the military justice system. Over one hundred members of Companies I, L, and M were prosecuted in three courts-martial in late 1917 and early 1918. The first was the largest in U.S. Army history, with sixty-three men tried. Charges accused them of disobeying orders, mutiny, murder, and felonious assault, of which the judges convicted every defendant. According to the Army, in disobeying their battalion commander and in gathering weapons with which they, with premeditation and during a time of war, killed city policemen, the defendants "did forcibly subvert and override military authority... with the intent of marching upon the City of Houston, Texas, to the injury of the persons and property therein situated." Survivors of the riot often testified to the courtroom in crutches or while displaying the bullet that pierced their bodies, providing emotion-eliciting signs of guilt for the defendants. During the proceedings, white witnesses tended to struggle to identify specific individuals when detailing their accounts, and the dark, rainy nature of the night cast doubts on any positive identification. Black soldiers who did not rebel gave the specific names of those they saw return from the city. Twenty of the jailed mutineers turned state's evidence. In their plea deals, they stated that their comrades coerced them into participating in the revolt, either true or a means for the men to minimize their share of the responsibility. According to the head prosecutor, Major D. V. Sutphin, the case determined guilt based on 
conspiracy, meaning individual words and actions implicated anyone tied to the scheme. Mutiny, he believed, entailed not just active involvement, but also mere presence and compliance. ${ }^{379}$

Headed by Major Harry S. Grier, the defense focused on alibis, as well as accusing those who cooperated with the prosecution of cowardice. The sixteen defendants who testified under oath generally contended that they hid in a building, tent, or among vegetation to save their lives from the approaching mob. Contradictions existed between these statements and those of corroborating witnesses. While these discrepancies resulted from either dishonesty or the fear among the civilians of facing prosecution for sheltering fugitives, they deprived alibis of substantiation. Hurting the defendants' cases further was the frequency with which they answered questions under cross-examination with "I don't know" and "I don't remember." Regarding the claimed flights to safety, the judges notified the accused that they needed to honor their duty to obey orders, exhibit loyalty to their officers, willingly die if needed, and recognize that being under fire is an expectation of enlistment. Regarding those who turned state's evidence, Company I's Grover Burns proclaimed that "these men are doing that to save their lives. They would recognize anyone the investigating board tells them to." When someone faced the prospect of death or years of hard labor as a consequence for mutinying, they had the choice to improve their livelihood in exchange for betraying comrades, which the defendants refused. ${ }^{380}$

\footnotetext{
379 Proceedings of a GCM, Trial of William Nesbit, et. al., RG 153 and 393, NARA, http://cdm16035.contentdm.oclc.org/cdm/singleitem/collection/p15568coll1/id/2058/rec/16.

${ }^{380}$ Ibid.; "PRESIDENT SAVES RIOTERS.; Commutes Sentences of Half a Score of Negro Soldiers Convicted of Murder," September 5, 1918, New York Times; "Negro Soldiers on Trial for Mutiny at Houston Aug. 23," November 2, 1917, Houston Daily Post, Harry S. and James L. Grier Papers, Box 3, USAHEC; "Silence Reigned as Citizens Told of Bloody Night," November 7, 1917, Ibid.; "20 Negro Soldiers in Mutiny Turned State's Evidence," November 11, 1917, Ibid.; "Participants in Houston Mutiny to Give Evidence," November 13, 1917, Ibid.; "Evidence Against Mutinous Negroes Shows Their Guilt," November 15, 1917, Ibid.; "Negroes May Try to Prove Alibis," November 18, 1917, Ibid.; "Negroes Tried to Prove They Had No Part in Murders," November 19, 1917, Ibid.; "Four More Negroes Denied Being in Raid on Houston," November 20, 1917, Ibid.; "Accused Negroes Appear to Possess Faulty Memories," November 21, 1917, Ibid.; "Defense Rested Courtmartial at San Antonio," November 23, 1917, Ibid.; "Fate of Negroes Who Mutinied is Now with Court," November 26, 1917, Ibid.
} 
The second and third courts-martial of the Houston rioters were smaller affairs. Between mid-December 1917 and early 1918, eighteen faced prosecution for murdering a single individual — the jitney driver E. M. Jones—and for deserting their posts "in a mutinous manner." All had served as guards for Camp Logan's warehouses. In the final trial, held in February 1918, the remaining forty mutineers were tried for the same offenses as those of the first case. ${ }^{381}$

Confirming the acute risk that all mutineers took throughout the long emancipation era, ninety-one percent—one hundred ten of one hundred twenty-one—of the Twenty-fourth's raiders received convictions. Twenty-nine faced death. The court sent sixty-three to prison for life. Only the fortunate few with shorter sentences could be sure of returning to society. On the morning of December 11, 1917, in a scene illuminated by bonfires and the sunrise, the Army carried out the first trial's executions. The clicking, snapping, and thuds heard at the gallows indicated that thirteen men had paid the ultimate price for resisting white supremacy. The Army performed the deed secretly and swiftly after conviction, forestalling a presidential review, appeal, or commutation. Ironically, Corporal Baltimore lost his life in 1917, not from abusive police officers in the late summer, but from Army executioners on the same winter morning as the other doomed men. In a final demonstration of the solidarity that drove them to do literal battle with Jim Crow, the condemned sang hymns on their way to the gallows. Convinced that the conspiracy persisted because the imprisoned never stopped maintaining their innocence, officials rejected calls for clemency. Meanwhile, Officer Sparks was acquitted of assault. ${ }^{382}$

\footnotetext{
381 "Interesting Developments Expected in Anderson Trial," November 15, 1917, Ibid; "Forty Negroes are Ordered Sent Here for Court-Martial," January 31, 1818, San Antonio Express, Ibid.; Proceedings of GCM, Trial of John Washington, et. al., RG 153 and 393, NARA, http://cdm16035.contentdm.oclc.org/cdm/singleitem/collection/p15568coll1/id/2055/rec/7; Proceedings of GCM, Trial of Robert Tillman et. al., Case No. 114575, RG 153 and 393, NARA, http://cdm16035.contentdm.oclc.org/cdm/singleitem/collection/p15568coll1/id/2070/rec/4.

382 C. Calvin Smith, "The Houston Riot of 1917, Revisited," in Buffalo Soldiers in the West, eds., Bruce Glasrud and Michael Searles, 212; Proceedings of a GCM, Trial of William Nesbit, et. al., RG 153 and 393, NARA, http://cdm16035.contentdm.oclc.org/cdm/singleitem/collection/p15568coll1/id/2058/rec/16; Proceedings of GCM,
} 
Through petitions, the NAACP pushed for sentence reductions, with mixed results. The documents grounded their appeals on the men's previously clean records, the "terrific burden" hostile white Houstonians posed to troops, and the speedy executions, which as one put it, "had savored of vengeance rather than of justice... a visitation upon their color rather than upon their crime." Presented with 12,000 signatures from the civil rights organization, President Wilson commuted ten death sentences to life in prison. 50,000 more signatures in 1921 persuaded Warren G. Harding to cut five life sentences to fifteen-year terms. By the 1930s, the Army released every mutineer still in prison. These petitions represented a partial achievement for African-American due process rights. Along with the socioeconomic, familial, and bodily autonomy envisioned since the days of slavery, the proponents of full racial equality and the completion of the emancipation process needed to clarify that African-American freedom possessed substance only when black defendants stood trial on the basis of evidence and the nature of the crime. However, that the freedoms needed extensive lobbying and not the sympathy of a white judge advocate general, as was the case in the nineteenth century, further underlines the poor state of the long emancipation process in the early twentieth century. ${ }^{383}$

White Americans interpreted the Houston Riot in terms that confirmed racial stereotypes. Houston's white press sympathized with the civilian casualties, describing them during the courtmartial proceedings as "the bereaved, the injured... and the terror-stricken." Meanwhile, the defendants constituted a "savage band" with a "ghoulish lust" for "human blood." According to

Trial of John Washington, et. al., RG 153 and 393, NARA, http://cdm16035.contentdm.oclc.org/cdm/singleitem/collection/p15568coll1/id/2055/rec/7; Proceedings of GCM, Trial of Robert Tillman et. al., Case No. 114575, RG 153 and 393, NARA, http://cdm16035.contentdm.oclc.org/cdm/singleitem/collection/p15568coll1/id/2070/rec/4; "Prosecution Will Likely Rest Riot Trial Saturday," November 24, 1917, San Antonio Express, Harry S. and James L. Grier Papers, Box 3, USAHEC.

${ }^{383}$ NAACP, Report of the National Association for the Advancement of Colored People for the Years 1917 and 1918 (New York: NAACP National Office, 1919), 35, 84 (quotes); "Memorandum of Activities of N.A.A.C.P. in the Houston, Texas, Riot Cases since their Inception," The Crisis, Volume 27, No. 1 (November 1923): 166-167. 
the San Antonio Light, the mutiny's true motivation was "race hatred." The Atlanta-based Presbyterian of the South pessimistically reflected on what the mutiny meant for race relations during the rest of the Great War: "Those who know the negro, know that he is going to give the government some hard problems to solve before the war is over. It is going to require a great deal of...hard work to make him an obedient, dependable soldier." For conservative whites, the Houston Riot proved that men who lacked the capacity for soldiering constituted the vicious beasts that long occupied their nightmares. That November, residents of Douglas, Arizona, received a warning from the Twenty-fourth U.S. Infantry that they "would see that the reputation of the $24^{\text {th }}$ was maintained" if the town's movie theater showed Birth of a Nation. The mayor ordered the police to block its viewing. This threat proved fitting, since the unit rose up against a social order that justified its existence on the brutish black caricature depicted in the 1915 film. ${ }^{384}$

The African-American population sympathized with the defendants. During the trial proceedings, among the spectators were prominent black community members such as teachers, pastors, and Pullman porters. As the San Antonio Express described it, "the presence of these... race members seemed to shed forth a glimmer of light that...could be visibly seen on the faces of the accused men in the form of a smile of great appreciation." After the Army carried out its punishments of the mutineers, the black press led an outcry. Writers refused to condemn the original offense, recommended revenge, and denounced what they saw as a miscarriage of justice. The NAACP-affiliated paper The Crisis painted the executed as "martyrs for the cause of

\footnotetext{
384 “Attack on Houston By Negro Soldiers Is Told By Victims," November 5, 1917, Houston Daily Post, Harry S. and James L. Grier Papers, Box 3, USAHEC (first quote), "Silence Reigned as Citizens Told of Bloody Night," November 7, 1917, Ibid. (second quote); "Killing of Captain Mattes Related by Wounded Man," "Trail of Negroes who Mutinied is being Established," November 9, 1917, Ibid. (third quote); "Mayor of Douglas Feared Negro Soldiers," November 2, 1917, Ibid. (fifth quote); "Motive was Race Hatred?", November 7, 1917, San Antonio Light, Ibid. (fourth quote); “A Disgrace to Our Army,” August 29, 1917, Presbyterian of the South, https://www.newspapers.com/newspage/465254628/ (fourth quote).
} 
democracy.” Thus, like the Buffalo Soldiers, African Americans in general understood the Houston Riot in terms of what it revealed about the state of U.S. democracy. Both historians and Houstonians are still coming to grips with the legacy of this bloody tragedy. ${ }^{385}$

African-American journalists had a case in condemning the manner in which the government punished the Houston rioters. A decade earlier, dishonorable discharges went to an entire battalion when not enough evidence existed to warrant a court-martial. That event, plus the execution of thirteen men in another battalion without a presidential review, demonstrated the great decline in the extent to which the U.S. Army honored the due process rights of its Sable Arm. In contrast, the eight troops sentenced to death for partaking in the also bloody San Pedro Springs mutiny fifty years prior all escaped execution. With the emancipation process in free fall in the early twentieth century, a mere accusation could lead to a black unit's mass conviction by executive decision and the government was less likely to commute a death penalty.

The mutineers emerging from the U.S. Army's first black regulars between Reconstruction and the Great War occupy a central junction in the African-American freedom struggle. The original Buffalo Soldiers advanced the phase of the emancipation process following the disbanding of the USCTs and during the rebuilding of the Union; later generations ushered in the stage of this process tasked with countering the rise of a new racial caste system. These developments proved that the promises of the Civil War era were still out of reach and increasingly under siege for most African Americans, even as their formerly enslaved relatives

\footnotetext{
385 "63 Members of $24^{\text {th }}$ Infantry on Trial for Murder and Mutiny," November 10, 1917, San Antonio Express, Harry S. and James L. Grier Papers, Box 3, USAHEC; The Crisis, October 17, 1917, 284-285. For recent Texans' reflections on the Houston Riot, see Mike Tolson, "The ugly history of Camp Logan: Century-old mutiny at Houston military site was rooted in racism, buried for years," August 19, 2017, Houston Chronicle, https://www.houstonchronicle.com/news/houston-texas/houston/article/The-ugly-history-of-Camp-Logan11944840.php (accessed 10/11/2019); Mitch Mitchell, "Buffalo Soldiers hanged after 1917 race riot should be pardoned, advocates say," November 19, 2018, Fort Worth Star-Telegram, https://www.startelegram.com/news/state/texas/article221379955.html (accessed 10/11/2019).
} 
aged and passed away. At this point in time, mutiny and similar forms of resistance remained a desirable option for the least patient and most frustrated black men in uniform. Despite the U.S. Army's four black regiments compiling a stellar record of service in the West and overseas, members endured murder and harassment from fellow countrymen seemingly incapable of appreciating them. When soldiers retaliated, with or without solid evidence proving they participated, they could not know whether they would enjoy leniency or suffer penalties devoid of opportunities for appeal or exoneration. The discharged men of Brownsville and the Houston uprising's surviving veterans could only look forward to additional racial oppression in the interwar period. By the mid-twentieth century, the last generation of Buffalo Soldiers, along with a new wave of African-American units on land, sea, and air, took advantage of another world war and later, a regional conflict to launch further attempts at completing the emancipation process. Like their predecessors, many decided to do so by mutinying against white supremacy. 


\section{Conclusion}

The range of choices uniformed African-American men faced when deciding how to best advance the long emancipation process during the nineteenth century - to mutiny, riot, petition, testify for or against comrades, suppress a revolt, or continue doing one's duty—set the stage for their twentieth-century descendants who continued to confront racism. From the American Revolution to the Great War, African Americans hoped that military service would finally persuade their white countrymen to recognize their right to bodily autonomy, family stability, and socioeconomic independence. When sobering realities contradicted this dream, and authorities ignored their plight, they viewed work stoppages and armed confrontations as their only remaining recourses. As African-American society organized to return the country to its egalitarian roots between the 1940s and 1970s, frustrated black servicemen did their part by tapping into the same tradition of black resistance that began under slavery and gained steam in civilian free labor arrangements and the armed forces. Whenever the possibility existed for African-American citizenship rights to expand in the midst of an armed conflict and an existential crisis for the republic, there was usually a corresponding increase in the number of munities in black units, which in turn formed part of a broader effort to realize the dream of racial equality. The repressive nature of American race relations during the Jim Crow era filtered into all branches of the armed forces, making resistance outside of the Army more common than ever as the country waged war against fascism and communism. While the Army's land units held a monopoly on black mutinies since the Civil War, starting in World War II, the sable arms of both the Navy and what eventually became the Air Force launched their own mutinous waves.

The Navy's decision to segregate between the 1890s and 1910s marked a key development which led, in part, to this increase. The resulting changes in recruitment caused the 
New Navy's black personnel to assume a subordinate status and shrink to historic lows; black sailors made up under five percent of the Navy during the first decade of the new century and just one percent by the First World War. Whenever a black petty officer from the Old Navy retired, a white man replaced him; new enlistees' training confined them to mess, engine room, and officer service. In 1919, the Navy ceased enlisting African Americans altogether. The Navy reopened black recruitment in the 1930s, but only in service-related roles. This dramatic shift in naval race relations produced an image of the branch as a hostile place for African Americans. The emergence of an acute racial hierarchy in the Navy increased the likelihood of racially motivated mutinies by black sailors. ${ }^{386}$

Naval segregation paralleled a broader attack on black freedom across society. White southerners feared that black World War I veterans stationed in the North had acquired a rebellious streak, and white northerners resented the job competition brought by black migrants. Both trends caused a spike in lynchings and other race violence. Additionally, as military aviation developed during the interwar period, racial barriers to skilled training prevented all but a few blacks from becoming military pilots. The early twentieth century thus brought the emancipation process to its lowest point in decades. At mid-century, a militant generation revolted en masse against this system to jumpstart the emancipation process. ${ }^{387}$

\footnotetext{
386 John Derrell Sherwood, Black Sailor, White Navy: Racial Unrest in the Fleet during the Vietnam War Era (New York and London: New York University Press), 4-5; Charles Hughes Williams III, “'We Have...Kept the Negroes' Goodwill and Sent Them Away,"' MA Thesis, August 2008, Texas A\&M University; James Baker Farr, Black Odyssey: The Seafaring Traditions of Afro-Americans (New York: Peter Lang, 1989), 142; Frederick S. Harrod, "Jim Crow in the Navy (1798-1941)," United States Naval Institute Proceedings, Vol. 105, No. 9 (September 1979): 46-53.

387 John D. Sherwood, Black Sailor, White Navy, 5-6; Dennis Nelson, The Integration of the Negro into the U.S. Navy (New York: Farrar, Straus \& Young, 1951), 7-8; Michael Shawn Davis, "'Many of Them are Among My Best Men': The United States Navy Looks at its African American Crewmen,” PhD Dissertation, Kansas State University, 2011, v, 1-2, 53-54.
} 
Signs of this new resistance appeared early on. In 1907, in Redondo, California, a black sailor named Epps defied a ban of his participation in a dance. Several white sailors attempted to eject him, during which they brutally beat Epps while shouting, "lynch him!” Police officers rescued the black sailor before the white shipmen could carry out the grisly deed. Commenting on the New Navy's racial regime, the press documenting the incident commented that, "the color line is strictly drawn in the navy in social matters." A decade later, the militant energies unleashed by the Great War inspired African-American veterans to form militias, challenge racist laws, and advocate for racial equality worldwide. Meanwhile, African Americans who fled Jim Crow via the Great Migration became more cognizant of their subordinate status in a democratic republic. A movement towards ever-greater militancy and collective action was brewing. ${ }^{388}$

Black military historians generally agree that the Second World War constituted a watershed moment in race relations and civil rights. However, scholars of the mid-twentiethcentury integration of the American armed forces disagree over whether it took place during World War II or whether the conflict paved the way for it in later years. The numerous mutinies of the Second World War and the Vietnam conflict support a more nuanced interpretation that

\footnotetext{
${ }^{388}$ Paducah Evening Sun, November 25, 1907, https://access.newspaperarchive.com/us/kentucky/paducah/paducahevening-sun/1907/11-25/page-16/epps-sailor?page=2\&ndt=by\&py=1907\&pey=1908 (first quote); Logansport

Pharos Tribune, November 25, 1907, https://access.newspaperarchive.com/us/indiana/logansport/logansport-pharostribune/1907/11-25?tag=mutiny+negro+sailor\&rtserp=tags/mutiny?pep=negro-sailor\&page=5 (second quote);

Washington Evening Journal, November 25, 1907, https://access.newspaperarchive.com/us/iowa/washington/washington-evening-journal/1907/1125 ?tag=epps+sailor\&rtserp=tags/epps-sailor?ndt=by\&py=1900\&pey=1910\&psb=relevance; Bakersfield Californian, November 23, 1907, https://access.newspaperarchive.com/us/california/bakersfield/bakersfieldcalifornian/1907/11-23?tag=epps+sailor\&rtserp=tags/epps-sailor?ndt=by\&py=1900\&pey=1910\&psb=relevance; Indiana Evening Gazette, November 25, 1907, https://access.newspaperarchive.com/us/pennsylvania/indiana/indiana-evening-gazette/1907/11-25/page-3/eppssailor?ndt=by\&py=1907\&pey=1908\&psb=relevance; Chad L. Williams, Torchbearers of Democracy: African American Soldiers in the World War I Era (Chapel Hill: University of North Carolina Press, 2013).
} 
like the long emancipation in general, the progress of the modern civil rights struggle within the military was gradual and as such, rarely advanced enough to forestall mutinies. ${ }^{389}$

In a call back to the nineteenth century, an acute demand for manpower pushed the Navy and Army Air Corps to gradually lessen its racial restrictions. As the country mobilized for global war, every military branch began increasing its African-American representation through the Selective Service Act. In early 1939, President Roosevelt's Civilian Pilot Training Program started recruiting African Americans, who by 1941 created the first black combat squadrons. At Tuskegee, Alabama, the first African-American combat aviators received training, albeit in segregated command structures and while barred from becoming instructors. In March 1942, President Franklin Roosevelt ordered Navy Secretary Frank Knox to increase black enlistment. By March 1943, every military branch exhausted the pool of white volunteers, prompting them to begin increasing their proportional share of black recruits and lessening racial restrictions. The war saw the first African-American sailors win officer commissions. By 1945, 5.5 percent of sailors had African ancestry, high by twentieth-century standards. Despite shortcomings, the causes of black autonomy and upward mobility continue to gain ground. When they encountered

\footnotetext{
389 Dennis Nelson, The Integration of the Negro in the U.S. Navy; Michael S. Davis, "'Many of Them are Among My Best Men,"” v, 1, 10; Morris J. MacGregor, Jr., Integration of the Armed Forces, 1940-1965 (Washington, D.C.: Center of Military History, 1989); Richard M. Dalfiume, Desegregation of the U.S. Armed Forces: Fighting on Two Fronts, 1939-1953 (Columbia, MO: University of Missouri Press, 1969); Richard Stillman II, Integration of the Negro in the U.S. Armed Forces (Praeger, 1968); Gerald Astor, The Right to Fight: A History of African Americans in the Military (Novato, CA: Presidio Press, 1998); Robert W. Mullen's Blacks in America's Wars: The Shift in Attitudes from the Revolutionary War to Vietnam (Pathfinder Press, 1973); Robert J. Schneller, Jr., Breaking the Color Barrier: The U.S. Naval Academy's First African American Midshipmen and the Struggle for Racial Equality (New York: New York University Press, 2005); Bernard C. Nalty, Long Passage to Korea: Black Sailors and the Integration of the U.S. Navy (Washington, D.C.: Navy Historical Center, 2003). Michael Davis contends that the global war itself, not the postwar era, was the "critical period" that transformed the branch's racial attitudes. According to Nelson, World War II and the early postwar years signified the Navy's shift from judging recruits based on race to merit. For the dark side of the merit-based system, see the Vietnam War section of this chapter. MacGregor points to the large infusion of black sailors resulting from the 1940 draft law. Finally, Dalfiume attributes integration to the country's Cold War status as leader of the democratic world. On the far end of the spectrum are historians like Bernard Nalty, according to whom it was not until the socio-political storms of the 1960s and 1970s that African Americans were able to enjoy equal status in the armed forces in general and the Navy in particular.
} 
hurdles to this progress, African-American servicemen, including sailors, decided on mutinous behavior as a last-ditch means of overcoming them. ${ }^{390}$

World War II's black naval mutinies resulted from what Lieutenant Dennis Nelson, the most successful of the Navy's first black officers, accurately described after the war as "lack of advancement," along with "intolerable social conditions and unfair treatment—conditions which they sought to remedy or to openly resist in one form or another.” Although Nelson thought Army mutinies more violent than Naval ones, a fresh look at the African-American mutinies of the 1940s finds more commonalities across the sable arms of both branches, a reflection of the greater militancy of African-American society in general by the mid-twentieth century. Further, igniting mutinous and riotous spirits was how northern blacks used their upbringing in a freer region to push change in the more oppressive South. Through mutinies, we can examine a reversal of the Great Migration's South-North trajectory. Northern-born black servicemen stationed in the Jim Crow South during the Second World War would have felt that their own advancement in the long emancipation process resulting from their families' migration was in danger of regression to the level of black southerners who stayed. ${ }^{391}$

The work stoppage form of mutiny remained part of black mutineers' repertoire during the Second World War. The largest and most notable example involved blacks working at the

\footnotetext{
${ }^{390}$ Stanley Sandier, Segregated Skies: All-Black Combat Squadrons of WWII (Washington, DC: Smithsonian Institution Press, 1992). Another way in which the Second World War was a watershed in the history of AfricanAmerican military service was its creation of the first black Marines. Until this point, the Marine Corps had always outright banned black enlistees. For the Marine Corps' Sable Arm, see Melton A. McLaurin, The Marines of Montford Point : America's First Black Marines (Chapel Hill: University of North Carolina Press, 2009) and Sandra M. Bolzenius, Glory in Their Spirit: How Four Black Women Took On the Army during World War II (Urbana: University of Illinois Press, 2018).

${ }^{391}$ Dennis Nelson, The Integration of the Negro into the U.S. Navy, 76 (first quote), 77 (second quote); For the southern occupation experience of black servicemen, see Ulysses Lee, United States Army in World War II: The Employment of Negro Troops (Washington, D.C.: U.S. Army Center of Military History, 2001), 348-379; James A. Burran, "Racial Violence in the South During World War II," Ph.D. dissertation, University of Tennessee, 1977; Homicide, Assault, and Lynching, Violence Against African American Military Personnel, March-November 1942, Black Freedom Struggle in the 20th Century, ProQuest History Vault.
} 
Port Chicago Naval Magazine in the San Francisco Bay area, built in the aftermath of the Pearl

Harbor attack. Here, dockworkers paused their duty to demand safer working conditions.

Mirroring the equal pay mutinies of the Civil War, this episode eighty years later sought rights

and used methods traditionally associated with labor activism. Further, it presents a deadly

example of the consequences of the New Navy's segregated system. Due to the leadership's

decision to limit seagoing operations to whites, African Americans made up the bulk of the

personnel at ammunition depots and magazines. Like USCTs in the Texas Expedition and

generations of Buffalo Soldiers, the Port Chicago base required these individuals to perform

grueling, tedious labor quickly and around the clock in geographic isolation and without access

to recreation, a situation which reduced morale and increased discontent. A subsequent court of

inquiry discovered that the black stevedores and their white officers stationed at the Port Chicago

base lacked adequate training and proper safety regulations. ${ }^{392}$

A tragic accident prompted the mutiny, which in turn attracted national attention. On July

17, 1944, two cargo ships loading ammunition on the decks of Port Chicago exploded, killing

three hundred men and wounding two hundred and fifty more. Two hundred and fifty of the dead

were African American, and blacks also made up most of the wounded. On August 9, 1944, the

survivors refused to resume their loading duties until the service improved their safety

\footnotetext{
392 Steve Sheinkin, The Port Chicago 50: Disaster, Mutiny, and the Fight for Civil Rights (New York: Roaring Brook Press, 2014); Court of Inquiry, "Port Chicago Naval Magazine Explosion on 17 July 1944: Finding of Facts, Opinion and Recommendations," https://www.history.navy.mil/research/library/online-reading-room/title-listalphabetically/p/port-chicago-ca-explosion/online-documents/court-of-inquiry.html. In the spring of 1944, five northern black soldiers in Florida also refused to perform their duty until granted a setting in which they could convey their opposition to such mistreatment. For disrupting state-side military base life to force an improvement of their right to purchase which products they want and stand up for themselves, these men suffered dishonorable discharges and multi-year prison sentences. Illustrating the links between mutiny, the long emancipation process, and the wartime genesis of the modern civil rights struggle, black newspapers protested this verdict. The Pittsburgh Courier demanded: "Please tell me how the President of the United States knowing that we are at war, allows the Negro soldier to be treated so intolerably?" See Gary R. Mormino, “Gi Joe Meets Jim Crow: Racial Violence and Reform in World War II Florida," Florida Historical Quarterly, Vol. 73, No. 1 (Jul., 1994), pp. 23-42; Pittsburgh Courier, January 8, 1944, July 29, 1944 (quote); Tallahassee Daily Democrat, May 4, 1944; Fort Lauderdale Daily News, May 4, 1944, https://search-proquest-com.www.libproxy.wvu.edu/.
} 
conditions, fearing a repeat of the disaster. The naval district commandant and other officials spent a week persuading the men to return to duty. Gradually, most of the 400 men agreed to resume loading, with 208 losing three months' pay for disobeying orders. A naval court-martial convicted the remaining fifty holdouts, now popularly known as the "Port Chicago 50," of mutiny. They received dishonorable discharges and hard labor sentences ranging from eight to fifteen years. However, due to the justifiable circumstances, youth, clean records, and short time in the service, Rear Admiral Carleton Wright issued reduced sentences for forty of them. The African-American press and organizations objected to the mutiny charges, arguing that the officers merely asked, rather than ordered, the men to load and that court-martialing the men as a group wrongfully implied they were all equally guilty. NAACP attorney Thurgood Marshall tried to appeal the decision through the Navy's judge advocate general. However, in July 1945, the Navy Department deemed the sentences legal and the trial fair and impartial. Under subsequent public pressure, the Navy decided in January 1946 to overturn the convictions and restore the men to active duty on probation. The Port Chicago Mutiny and smaller-scale incidents persuaded the Navy to end the policy of disproportionately manning magazines and depots with black units. Though racism sparked black mutinies, due process rights and their promotion by activism reduced the severity of punishment for them. ${ }^{393}$

Race riots persisted as a theater of black military resistance to white supremacy. The placement of black servicemen in white southern communities during World War II led to the same acts of martial masculinity as perpetrated by Reconstruction occupation forces and Buffalo

\footnotetext{
${ }^{393}$ Dennis Nelson, The Integration of the Negro into the U.S. Navy, 77-81; Attachment to War Diary, July 17, 1944, https://www.history.navy.mil/research/library/online-reading-room/title-list-alphabetically/p/port-chicago-caexplosion/online-documents/war-diary.html; "50 SAILORS GET LONG TERMS IN MUTINY CASE," Atlanta Daily World, November 19, 1944, https://search-proquestcom.www.libproxy.wvu.edu/docview/490755061/fulltextPDF/B1EC303F3DD74FEEPQ/2?accountid=2837; "The Mass Trials," Pittsburgh Courier, March 10, 1945, https://search-proquestcom.pentagonlibrary.idm.oclc.org/docview/202180181/2CAEEC4516BC4DCFPQ/49?accountid=6768.
} 
Soldiers in retaliation against civilian racism. Thus, these latest troops demonstrated a willingness to violently avenge comrades whom Jim Crow's legions had attacked.

Throughout the conflict, the Army stationed African Americans in and around Tallahassee, Florida. The northerners of the $1869^{\text {th }}$ Engineering Aviation Battalion noted grievances during their time in this corner of the Jim Crow South: "Above all we have Southern White Crackers as officers over us who abuse us, and treat us worse than we would treat the lowest of dogs." The engineers next contended that Axis prisoners of war received better treatment than them. Such a situation contradicted with the respect they thought they deserved as members of the armed forces. ${ }^{394}$

These tensions escalated by April 1945. Two hundred fifty soldiers and airmen from Dale Mabry Field and Camp Gordon Johnston assaulted Tallahassee's Frenchtown. Using colorful language as threats, this group warned that they planned to "paint it [Frenchtown] red" and "tear it apart." The raiders plundered businesses until civil and military policemen targeted them with tear gas and put them into custody. Like they had done for nearly a century, black men in uniform became so aggravated with racist abuse that they enacted bloody revenge via insurrection, the same course as the most desperate and courageous slaves of early America. ${ }^{395}$

\footnotetext{
${ }^{394}$ Gary R. Mormino, "Gi Joe Meets Jim Crow: Racial Violence and Reform in World War II Florida”; "Mistreatment of Negro Soldiers in Dixie," Papers of the NAACP, pt. 9, ser. B, "Discrimination in the U.S. Armed Forces, 1918-1955," Armed Forces Legal Files, 1940-1950, roll 13, 613-14 (quote); Jon Evans, "The Origins of Tallahassee's Racial Disturbance Plan: Segregation, Racial Tensions, and Violence during World War II," Florida Historical Quarterly Vol. 79, No. 3, (2001): 346-364.

${ }^{395}$ Tallahassee Daily Democrat, April 2, 4, 1945; Gadsden County News, April 5, 1945; Tampa Bulletin, April 21, 1945, https://access.newspaperarchive.com/; For a mutiny in the western corner of the Jim Crow South, see Claire DeLucca "Both Sides of the Barbed Wire: Lives of German Prisoners of War and African Americans in Camp Claiborne, Louisiana, 1944-1946," MA thesis, University of New Orleans, 2018; Kari Frederickson, The Dixiecrat Revolt and the End of the Solid South (Chapel Hill: University of North Carolina Press, 2001), 31-32; Adam Fairclough, Race \& Democracy: The Civil Rights Struggle in Louisiana, 1915-1972 (Athens: University of Georgia Press, 2008), 78; James Albert Burran, "Racial Violence in the South During World War II," 215; Papers of the NAACP, "Discrimination in the U.S. Armed Forces, 1918-1955," Volume 2, file folder 0360.
} 
As U.S. armed forces advanced around the globe during 1940s, mutinous actions advanced with them. With the great mutinous wave of World War II expanding geographically, the Navy again experienced racial rebellions of the sort historically reserved for the Army. In the second half of 1944, race riots erupted between black sailors and white Marines stationed on Guam. On Christmas Eve, 1944, a band of the latter fired on a group of the former and drove them out of the island's main town for romantically pursuing native women. Later that evening, a truckload of white Marines attacked the African-American camp, threatening them and accusing a black sailor of throwing a stone at one white Marine's head. On Christmas day, a rumor spread saying that a white Marine had killed a black sailor and wounded another. On Christmas night, without permission, forty armed black sailors left the depot in three military vehicles to inflict revenge. However, the black master-at-arms reported their departure, leading white military policemen to intercept the vehicle and apprehend the sailors. Their court-martial charged them with rioting and unlawfully possessing and using U.S. property. Many organizations on the mainland immediately worked on the sailors' behalf until January 1946, when the Navy released and cleared the remaining thirty-six men serving time. The Navy sent those with shorter sentences or merely suspected of involvement in the incident to other island bases. These incidents at Guam represent a successor to 1860s-era acts of resistance against white attempts to regulate the intimate lives of blacks. From slavery to the modern civil rights era, personal autonomy remained a central feature of African Americans' full emancipation. ${ }^{396}$

For the first time since the Civil War's equal pay campaign, the peaceful and aggressive protests of African Americans in World War II pushed the federal government to revise racial policy. In April 1944, President Roosevelt selected James V. Forrestal as the new Navy

\footnotetext{
${ }^{396}$ Dennis Nelson, The Integration of the Negro into the U.S. Navy, 82-84.
} 
Secretary. Previously involved in the National Urban League's civil rights efforts, Forrestal spoke out in defense of African-American sailors. As he informed Admiral King, he did not "think that our Navy negro personnel are getting a square break. I want to do something about it." In his Guide to Command of Negro Naval Personnel, Forrestal advocated for a merit-based system, one in which "The Navy accepts no theories of racial differences in inborn ability, but expects that every man wearing its uniform be trained and used in accordance with his maximum individual capacity determined on the basis of individual performance." However, the postwar years demonstrated that this alteration merely replaced de jure segregation with its de facto sibling. ${ }^{397}$

While some African-American mutinies during the Second World War built on old traditions of black military resistance, others foreshadowed newer traditions, including the modern civil rights movement's tactics of civil disobedience against segregation laws. In April 1945, the 477th Bombardment Group, an all-black cadet unit and component of the famed Tuskegee Airmen, resisted the establishment of separate officers' clubs while training to fly B25s at Freeman Field, Indiana. Formed in January 1944, this command never went overseas due to both its late arrival in the conflict and delays resulting from its navigators and bombardiers needing to train in different, segregated bases. Its existence owed to the wartime decision of the Army Air Corps, under pressure from the NAACP and the African-American press, to welcome black pilots for the first time. Freeman's base commander painted the club reorganization as the creation of one for trainers, the other for trainees. However, the black airmen recognized the underlying racial aims of the action, prompting them to demand entry into the trainer (white)

\footnotetext{
${ }^{397}$ John D. Sherwood, Black Sailor, White Navy, 9-10 (first quote); Navy Department, Guide To Command of Negro Naval Personnel (Washington, D.C.: Bureau of Naval Personnel, 1945), https://www.history.navy.mil/research/library/online-reading-room/title-list-alphabetically/g/guide-command-negronaval-personnel-navpers-15092.html (second quote).
} 
club. As James C. Warren recollected, "We decided there was only one thing left to do: go to the club." Unlike rebellions that escalated into violence or up-front embraced bloodshed, this group decided to engage in nonviolent direct action and simply walk into the club in several waves. Second Lieutenant Marsden A. Thompson walked into the club first. Coleman A. Young, of the same rank, observed white Lieutenant J. D. Rogers shove Thompson, who replied, "Take your hands off me." White superiors ultimately put 162 members of the $477^{\text {th }}$ into custody for either mutiny or refusing to obey wartime orders (to sign a formal endorsement of the new segregation policy). Warren reflected on the arrest: "It didn’t bother me a damn bit...We were young, educated, well trained and determined." Fortunately for the men, their action was consistent with Army regulations, which guaranteed all officers membership in base officer clubs, and attracted protests on their behalf. Everyone except Second Lieutenant Roger Terry, who was fined \$150, won exonerations. They afterward enjoyed a leadership change from a white commander to Colonel Benjamin O. Davis, Jr., a distinguished combat pilot who eventually became the Air Force's first African-American general. ${ }^{398}$

Despite being ahead of its time in terms of civil rights activism, the 477th's stand against segregation in the Air Corps presents holdovers from the nineteenth century's African-American mutinies. First, white officers classified even the most minor acts of resistance by black servicemen as mutinous if their effect was to challenge a social hierarchy. Also, regardless of whether the "Freeman Field Mutiny" accurately falls under the term's definition or not, it

\footnotetext{
${ }^{398}$ Alan Osur, Blacks in the Army Air Forces During WWII: The Problems of Race Relations (Honolulu, Hawaii: University Press of the Pacific, 2005), 40, 57, 86, 108-122; Robert Louis DalColletto, "Lt. Col. James C. Warren: Tuskegee Airman, American Hero," Airport Journals, October 1, 2006, http://airportjournals.com/lt-col-james-cwarren-tuskegee-airman-american-hero/ (quotes). Also see Benjamin O. Davis, Jr., American: An Autobiography (Washington, D.C.: Smithsonian Institution Press, 1991); Von Hardesty, Black Wings: Courageous Stories of African Americans in Aviation and Space History (New York: HarperCollins, 2008); Stanley Sandler, Segregated Skies. Despite the favorable outcome, reprimands containing statements like "He displayed an uncooperative and stubborn attitude toward constituted authority" stifled the military career opportunities of the Freeman Field mutineers after the conflict.
} 
historically matches the standard for a racially motivated black mutiny. Like the USCTs and Buffalo Soldiers, participants in this episode benefitted from a recent breakthrough in the emancipation process (military aviation opening up to blacks) but stood up against limits to this breakthrough in the hopes of advancing their rights further. Finally, despite being charged with crimes punishable by death, the Freeman Field mutineers earned enough sympathy from other whites to avoid substantial punishment.

Consistent with long emancipation mutinies across the decades, the above revolts from black sailors and airmen represent examples of African-American frustrations boiling over because white authorities had deprived them of a formal, legal recourse to settle their grievances and created an environment in which numerous grievances formed and festered. In the absence of such avenues, mere grumbling turned into physical and verbal clashes. Only white respect for black men's due process rights and safety prevented such tensions from boiling over.

Possessing white allies paid the same sorts of dividends during World War II as it did throughout the long emancipation. White commanders forestalled or reduced racial tensions by actively solving grievances, improving training, offering recreational opportunities, and fostering communication between white and black personnel. This was especially the case in the Second Air Force, whose commander General St. Clair Streett took a hard line against discrimination. Additionally, African Americans stationed at British bases enjoyed better treatment, and therefore were less prone to ill-discipline. As an aide to General Dwight D. Eisenhower remarked, "To most English people...the negro soldier is just another man... a jolly good fellow." Likewise, the English press praised the respectful behavior of African Americans stationed amongst them. While black troops in the U.K. operated under a uniform command structure that reduced racial tensions, those stationed in the U.S. experienced a wide array of 
racial climates based on their particular commander's approach to the race issue. The variables of geography and personality remained paramount in encouraging or precluding mutinies. ${ }^{399}$

The great number of black military mutinies during the Second World War led to debates over the proper course of action African Americans should take in the face of wartime racism: cautious gradualism or impatient resistance. A number of black leaders proposed alternative strategies to mutiny or other forms of resistance to racism in the armed forces. William $\mathrm{H}$. Hastie, a judge, NAACP member, and Civilian Aide to the Secretary of War, called on uniformed African Americans to focus on winning the war and to leave civil rights agitation to civilians like himself. While opposed to segregation and a proponent of civil rights within the FDR administration, he contended that "experiments within the Army in the solution of social problems are fraught with danger to efficiency, discipline, or morale." The numerous black revolts across the U.S. military during the Second World War reveals that many African Americans disagreed. Resistance, according to these individuals, was a necessity in every institution of the country if their race had any hope of realizing their full emancipation. ${ }^{400}$ Other public African-American voices, such as NAACP business manager George S. Schuyler, endorsed mutiny. In an op-ed for the Pittsburgh Courier, he cheered those "who have

\footnotetext{
${ }^{399}$ Alan M. Osur, Blacks in the Army Air Forces During WWII, 95-107 (quote on 96). The Bamber Bridge mutiny constituted an exception to this. See Fenneth P. Werrell, "Mutiny at Army Air Force Station 569: Bamber Bridge, England, June 1943," Aerospace Historian 22 (December 1975): 202-209. Even if racial oppression drove a unit to rebel, acquiring white allies later brought a degree of justice. In May 1944, the entire $457^{\text {th }}$ Aviation Squadron, then stationed at Herbert Smart Airport in Macon, Georgia, mutinied against the demotion and then dismissal of their first sergeant. The men conducted what one report described as a "sit-down strike," defying orders to fall in formation and perform their duties. An investigation afterward found that a contributing factor was the preponderance of incompetent and inexperienced leadership in African-American commands, which in turn lowered morale and discipline. This conclusion spared the men of disciplinary action. The rebellion of the $457^{\text {th }}$ offers an example of some African Americans enjoying enough due process and sympathy from white superiors that their decision to mutiny paid off. See Alan M. Osur, Blacks in the Army Air Forces During WWII, 103-104; James Gould Cozzens, A Time of War: Air Force Diaries and Pentagon Memos, 1943-45 (Bruccoli Clark, 1984), 135; Stanley Sandler, Segregated Skies, 82; Ulysses Lee, The Employment of Negro Troops, 340-341.

${ }^{400}$ William H. Hastie, On Clipped Wings: The Story of Jim Crow in the Army Air Corps (New York: National Association for the Advancement of Colored People, 1943), first quote on 7, second quote on 70, https://babel.hathitrust.org/cgi/pt?id=uiug.30112046364326\&view=1up\&seq=7.
} 
sufficient pride and courage to rebel against mistreatment and unfairness." He singled out the mutineers of Port Chicago, Camp Rousseau, and Freeman Field, arguing that their discrimination in the military surpassed its civilian form in severity because in the former, they could not escape to a freer area like the participants in the Great Migration could. Because these sailors and pilots were "men" lacking a "slavish craven" character, they each lack "enthusiasm for his task of risking his life to perpetuate a system which humiliates him and his people." To end the low morale that in turn sparked mutinous behavior, Schuyler argued that only one solution existed: "let him serve alongside his fellow citizens. Promote him according to his merits, and treat him as a hero." Overall, "we must treat them (black soldiers and sailors) not as Negroes, but as Americans." Only if whites finally agreed to stop blocking the culmination of the long emancipation process would the Army and Navy avoid black uprisings, which would in turn strengthen their fighting capacity through higher morale. The entire country would reap rewards from racial equality. African-American military mutinies had become so central to the long emancipation process and the long civil rights struggle that they had crossed over into the broader debate waging since W.E.B. Du Bois' pro-resistance Niagara Movement first condemned Booker T. Washington's Atlanta Compromise calling for accommodation. ${ }^{401}$

For a moment, it appeared that the emancipation process would finally be completed in the American armed forces following the conflict against European fascism and Japanese imperialism. In a groundbreaking action, in 1948, President Harry Truman issued Executive Order 9981, which established "equality of treatment and opportunity" for all military personnel regardless of race. Lieutenant Dennis Nelson reflected that the recent series of pro-integration

\footnotetext{
${ }^{401}$ George S. Schuyler, "Views and Reviews," The Pittsburgh Courier, April 21, 1945, https://search-proquestcom.pentagonlibrary.idm.oclc.org/docview/202158128/2CAEEC4516BC4DCFPQ/52? accountid=6768 (quotes); Booker T. Washington, "The Atlanta Compromise," September 18, 1895; W.E.B. Du Bois, "Of Booker T. Washington and Others," The Souls of Black Folk (Chicago: A. C. McClurg and Co., 1903), 41-59.
} 
naval directives "brought the nation closer to realizing its ideals" by removing racial barriers. Historians tend to interpret the Truman desegregation order as the culmination of the military sphere of the civil rights struggle or as part of a gradual process from the 1940s to 1960s. They point out that Army and Marine units successfully implemented Truman's order on Korean War battlefields to boost efficiency, while the Air Force immediately embraced integration after it became an independent branch. ${ }^{402}$

However, as recent scholars like John Darrell Sherwood and Natalie Kimbrough have revealed, a de facto version of segregation stubbornly persisted in the U.S. military into the 1970s, especially in the Navy. The problem was multifaceted: African Americans consistently viewed the Navy as a prejudiced institution, discouraging them from joining in any role; white naval leaders had a weak commitment to recruiting blacks; poor test scores reduced the pool of prospective black officers under the Navy's merit-based recruiting; and the perception among blacks across the branches that the justice system stood against them. After World War II, the number of black naval officers dropped from a wartime high of sixty to only three, while their overall percentage fell to three percent, with most black sailors returning to service roles. Despite the once strong African-American presence in the nineteenth-century maritime world, one vice admiral asserted that blacks were "not a seafaring people." As Admiral Elmo Zumwalt put it as late as 1976, "as far as breaking down racial barriers was concerned, the Navy was marching in

\footnotetext{
402 Harry Truman, "Executive Order 9981: Establishing the President's Committee on Equality of Treatment and Opportunity In the Armed Forces," July 26, 1948, https://www.ourdocuments.gov/doc.php?flash=false\&doc=84\&page=transcript; John D. Sherwood, Black Sailor, White Navy, 10-13 (first quote on 11); Dennis Nelson, The Integration of the Negro into the U.S. Navy, 188-190 (second quote), 193; Carsten Fries, "Port Chicago Naval Magazine Explosion: 17 July 1944," Naval History and Heritage Command, July 16, 2019, https://www.history.navy.mil/browse-by-topic/wars-conflicts-andoperations/world-war-ii/1944/port-chicago.html; Morris J. MacGregor, Integration of the Armed Forces, 1940-1965; Osur, Blacks in the Army Air Forces During World War II; Alan L. Gropman, The Air Force Integrates (Washington, D.C.: Office of Air Force History, 1985).
} 
the rear rank of the military services." With the long emancipation process further along than ever but still incomplete, one more outbreak of black mutinies approached. ${ }^{403}$

The Vietnam War, with the civil rights and black power movements serving as a backdrop, created the conditions for this outbreak. As higher-skilled whites flooded into the Navy and Air Force to avoid ground combat in Southeast Asia, the Army and Marines drafted disproportionately high numbers of working-class African Americans. The resulting high casualty rate for poor blacks in Vietnam enraged activists already demanding resolutions to poverty and police brutality in black communities. In the early 1970s, the Navy, to promote equal opportunity, relaxed recruitment standards following President Nixon's scaling back of the draft. This new policy brought in an influx of African Americans with minimal education. Though promised socioeconomic advancement away from the violent, drug-infested, impoverished communities emerging in postwar American cities, this naval underclass did not receive the training and education needed to rise above servile labor. Since white naval management clung to institutional racism, the likelihood of racially-motivated black revolts remained high. ${ }^{404}$

Early in the Vietnam conflict, U.S. ground forces primarily rebelled against racist superiors. Within the fragging epidemic among soldiers and Marines fighting in Vietnamese jungles were black enlistees who murdered white officers for dismissing grievances and frowning upon black organization. This trend increased in 1968 after Martin Luther King's assassination and Black Panther Party calls for black troops to "start killing the racist

\footnotetext{
${ }^{403}$ John Derrell Sherwood, Black Sailor, White Navy, 1 (last quote); Natalie Kimbrough, African Americans in the U.S. Military During the Vietnam War (Lanham, Maryland: University Press of America, 2007). For a study on black Korean War soldiers, see William T. Bowers, William M. Hammond, and George L. MacGarrigle, Black Soldier, White Army: The 24th Infantry Regiment in Korea (Washington, D.C.: U.S. Army Center of Military History, 2014).

${ }^{404}$ John Sherwood, Black Sailor, White Navy.
} 
pigs...giving you orders." These acts highlight how black men still felt that the Army constituted a wing of a white society that viewed their lives expendable. While ground forces were more integrated than those at sea, the process did not finish until after the Vietnam War. ${ }^{405}$

In the latter years of the conflict, naval sites became the centers of black rebellion. A massive wave of sit-down strikes and riots hit hundreds of vessels and bases between 1972 and 1974, including the aircraft carrier USS Kitty Hawk. While stationed off the coast of North Vietnam and conducting airstrikes in mid-October 1972, this ship's black crew rose up. They had endured a longer tour than scheduled and the most sorties of any aircraft carrier during a single Vietnam War deployment, which fatigued the men. To worsen the situation, whites held the ship's most prestigious positions while blacks toiled as messmen, and segregated living quarters perpetuated racial othering and alienation. The black section housed men from urban ghettos well-versed in a culture that gave them, as African-American Commander Benjamin Cloud later testified, "no real sense of loyalty to any organization other than their black brothers." Showing the influence of the black power movement, the black crewmen believed that "every deprivation of opportunity or privilege that the black man has had...can easily ... be laid at the door of blame of the white man." On October 12, petty squabbles in the mess hall over incorrect food orders and sailors accidentally stepping on comrades' feet escalated to black sailors indiscriminately beating whites and issuing threats of "kill, kill, kill the motherfucker" against officers. Cloud finally restored order by making the black power salute and begging a crowd of 150 mutineers to adopt Martin Luther King's peaceful approach to oppression, arguing that violence will only lead

\footnotetext{
${ }^{405}$ U.S. Senate, Committee on Government Operations, Hearings Before the Permanent Subcommittee on Government Operations, United States Senate, $91^{\text {st }}$ Congress, $1^{\text {st }}$ Session, Part 20 (Washington, U.S.: Government Printing Office, 1969), 5590 (quote). For scholarship on fragging, see George Lepre, Fragging: Why U.S. Soldiers Assaulted their Officers in Vietnam (Lubbock: Texas Tech University Press, 2011); Natalie Kimbrough, Equality Or Discrimination?, 90-93.
} 
to death. At least sixty sailors suffered injuries. Once the Kitty Hawk finished its tour, nineteen out of twenty-nine men were convicted for their participation. Punishments included pay forfeitures, rank reductions, and imprisonment; ringleader Airman Apprentice Terry Avinger, of Philadelphia's black section, won release for lack of a speedy trial. Rather than the structural barriers to black sailors' upward mobility, senior naval officials and congresspeople later blamed the Kitty Hawk mutiny on "thugs" and the early 1970s reforms, which they argued encouraged ill-discipline and radicalism. Going forward, however, the Navy focused on raising performance standards, coupled with affirmative action and the full integration of ships. By the turn of the twenty-first century, this shift bore fruit; the Navy has not just become more diverse, but its image among African Americans has become positive. ${ }^{406}$

Despite the achievements of the African-American freedom struggle in the mid-twentieth century, black sailor mutinies, once rare and small in the nineteenth century, expanded, becoming larger and more frequent. This resulted from issues that once exclusively plagued the Army: a persistent gap in the expectations about, and reality of, military service; barriers to resolving grievances; and the perception of racial oppression from commanders. Yet, a difference exists between earlier mutinies and those of Vietnam. Commander Cloud convinced a riotous mob to stand down by reminding his men of the counterproductive nature of martial masculinity. Perhaps civil rights' activists' success with nonviolent resistance, coupled with the failure of black power's call for armed self-defense, ended the reign of Frederick Douglass' archetypal slave who was willing to spill white blood.

During the two centuries in which African-American servicemen conducted mutinies and race riots, a few lessons present themselves. Their actions proved counterproductive for blacks

\footnotetext{
406 John Derrell Sherwood, Black Sailor, White Navy, 55-102 (first and second quotes on 60, third quote on 94). For the mutinies on the Constellation and Hassayampa, see Ibid., 103-149.
} 
because they ignited white fears of black savagery and invited further retaliation. While fighting designated enemies on the battlefield could and did prove black men's worthiness for citizenship rights, fighting one's officers or civilians, no matter how abusive, did not prove to whites this same worthiness. However, when human beings feel victimized by injustice, some inevitably desire the most destructive and costly methods of pursuing justice, especially when they feel they have nothing left to lose. Additionally, whites made the specter of black insurrection a selffulfilling prophecy by continuing to oppress African Americans generation after generation. Whenever a branch commissioned racist individuals as officers and rarely adequately punished those who abused their authority, the U.S. armed forces fostered an environment fertile for mutinies from those victimized by such policies and actions. A cycle of ignorance and hatred, which provoked frustration and vengeance, became ingrained in Army and Navy culture. Regardless of how or whether they shaped race relations in the military or society at large, rebellion in the ranks characterized the military experience of thousands of African-American warriors from the early republic to late-civil rights era. Though comprising a small portion of their military careers, the numerous aspects of the mutineer experience became strongly imprinted on their memories: the intense sentiments and painful ordeals that provoked mutinous conduct, the thrill of participating in the action, the sobering reflections while sitting for weeks or months in custody, and the range of emotions - nerves, devastation, and embarrassmentwhile being tried before their peers and superiors.

The phenomenon of black military mutinies forces Americans to come to terms with one of the most difficult aspects of their past, and the tradition of black resistance that encouraged such mutinies continues to influence U.S. society and politics into the early twenty-first century. The history of American race relations can be seen as a continuous dance of "two steps forward, 
one step back," or vice-versa. In the current era, African Americans and their white allies continue to express frustration over the United States' inability or unwillingness to fully purge itself of the fragments of slavery a century and a half after its destruction. Since the civil rights struggles of the mid-twentieth century, Americans have become more fully conscious of all forms of prejudice and have made unprecedented efforts in righting historical wrongs, from promoting greater upward mobility and educational opportunities to ensuring universal adult suffrage and increasing the proportion of people of holding political offices. However, African Americans remain disproportionately impoverished, under-represented in electoral politics, victimized by racial violence, and imprisoned. ${ }^{407}$ Therefore, the U.S. has yet to implement the full racial equality envisioned by slaves and freedpeople. While racially-motivated mutinies that once plagued the armed forces have become a distant memory, African Americans maintain their tradition of resistance to white supremacy, building on the mutinous actions of their ancestors, along with the non-violent lessons taught during the civil rights movement. Because African Americans continue to feel that the country has failed to live up to its egalitarian ideals, over the last decade, they have formed groups such as Black Lives Matter to bring attention to police brutality, clashed with white supremacists at places like Charlottesville, demanded steps to create a more equitable socioeconomic system, and joined fringe black separatist groups.

Regardless of the utility of their methods, the USCTs, Buffalo Soldiers, airmen, and sailors who rebelled against racial oppression understood that the key to winning one's freedom

\footnotetext{
${ }^{407}$ Samuel Stebbins and Thomas C. Frohlich, "The poverty rates for every group in the US: From age and sex to citizenship status," February 28, 2020, USA Today, https://www.usatoday.com/story/money/2019/11/06/unitedstates-poverty-rate-for-every-group/40546247/; Richard A. Oppel Jr. and Lazaro Gamio, "Minneapolis Police Use Force Against Black People at 7 Times the Rate of Whites," June 3, 2020, New York Times, https://www.nytimes.com/interactive/2020/06/03/us/minneapolis-police-use-of-force.html?auth=loginemail\&login=email; Michelle Alexander, The New Jim Crow: Mass Incarceration in the Age of Colorblindness (New York and London: The New Press, 2010); Anna Brown and Sara Atske, "Blacks have made gains in U.S. political leadership, but gaps remain," January 18, 2019, Pew Research Center, https://www.pewresearch.org/facttank/2019/01/18/blacks-have-made-gains-in-u-s-political-leadership-but-gaps-remain/.
} 
was to continuously fight for it, avoiding complacency. Victories in human rights causes often prove fragile, hollow, and prone to reversal. As such, the black resisters of the long emancipation era acted vigilantly to acquire, preserve, and regain their rights. When the Navy changed its status from the most racially progressive branch to the most regressive on racial matters, black sailors' likelihood of mutinying shifted from being rare to frequent. Whenever their compensation or physical treatment fell far short of expectations, black Army personnel from the 1860s to 1960 s rose up to demand a fairer military experience. Regardless of a social justice movement's success rate, its adherents can only keep their dream alive through tireless struggle. 


\section{Bibliography}

\section{Primary Sources}

\section{Manuscripts:}

Army Heritage and Education Center, Carlisle, Pennsylvania

William Gladstone Collection

Harry S. and James L. Grier Papers

$\underline{\text { H. Furlong Library, Maryland Historical Society, Baltimore, Maryland }}$

E. A. Williams Papers

Kentucky Historical Society, Frankfurt, Kentucky

Ellen Wallace and Annie Starling Diaries

National Archives (NARA), Washington, D.C.

RG 153: Records of the Office of the Judge Advocate General [War Department]

RG 125: Records of the Office of the Judge Advocate General [Navy Department]

RG 94: Records of the Adjutant General's Office

M233: Register of Enlistments in the U.S. Army

Southern Historical Collection, Wilson Library, University of North Carolina at Chapel Hill James Greenly Diary

Oneida Ship's Diary, 1862-1863

Special Collections, University of Kentucky Library, Lexington, Kentucky

Wickliffe-Preston Papers

University of Maryland Archives, College Park, Maryland

George DuBois Collection of Maryland Labor History

Virginia Museum of History and Culture, Richmond, Virginia.

"Caroline Littlepage Diary, 1864-1867"

West Virginia State Archives, Charleston, West Virginia

Canning Family Papers

WVU Downtown Library, Morgantown, West Virginia

"Proceedings of the Colored National Labor Convention held in Washington, D.C., on

December 6th, 7th, 8th, 9th, and 10th, 1869"

\section{Newspapers and Journals:}

Airport Journals

Albany Journal 
Army and Navy Journal

Atlanta Daily World

Atlanta Independent

Atlanta Weekly Constitution,

Aurora Dearborn Independent

Bakersfield Californian

Baltimore Sun

Barre Patriot

Boston Daily Advertiser

Boston Daily Journal

Boston Journal

Boston Morning Journal

Boston Post

Boston Post

Brooklyn Daily Eagle

Brownsville Herald

Burlington Daily Hawk Eye Gazette

Butte City Daily Miner

CBS News

Christian Recorder

Columbus Daily Enquirer

Columbus Daily Sun

Coshocton Age

Crawford Tribune

Daily Columbus Enquirer

Daily Constitutional Union

Daily Ohio Statesman

Douglass' Monthly

Fairfield Ledger

Fort Lauderdale Daily News

Fort Worth Star-Telegram

Gadsden County News

Georgia Baptist

Hagerstown Herald and Torch Light

Harper's Weekly

Hillsdale Standard

Houston Chronicle

Houston Daily Post

Huffington Post

Indiana Evening Gazette

Indianapolis Journal

Janesville Gazette

Jefferson City Peoples Tribune

Logansport Pharos Tribune

Madison Wisconsin State Journal

Milledgeville Southern Recorder 
Mitchell Sunday Republican

Monmouth Warren County Democrat

New Outlook

New York Herald

New York Times

Newport Mercury

North American Review

Omaha Progress

Paducah Evening Sun,

Petersburg Pike County Democrat

Philadelphia Age

Philadelphia Inquirer

Pine and Palm

Pittsburgh Courier

Presbyterian of the South

Princeton Union Democrat

Racine County Argus

Richmond Daily Dispatch

Richmond Planet

Rochester Union Spy

San Antonio Express

San Antonio Light

Staunton Spectator

Tallahassee Daily Democrat

Tallahassee Daily Democrat

Tampa Bulletin

The Boston Daily Atlas

The Cincinnati Commercial

The Colored American Magazine

The Crisis

The Daily Picayune

The Liberator

The Macon Daily Telegraph

The Nation

USA Today

Valley Spirit

Washington Evening Journal

Waterloo Courier

Weekly Anglo-African

Weekly Patriot and Union

Weekly Wisconsin Union

Online Resources:

Ancestry. https://www.ancestry.com/ 
Ayers Primary Sources. https://college.cengage.com/history/ayers_primary_sources/

Colored Conventions Project. Digital Records. https://omeka.coloredconventions.org/

Dr. Martin Luther King Jr. Smithsonian. https://www.si.edu/spotlight/mlk?page=4\&iframe=true

Fold3. https://www.fold3.com/

"Carded Records Showing Military Service of Soldiers Who Fought in Volunteer Organizations During the American Civil War, compiled 1890 - 1912, documenting the period 1861 - 1866.” M1822. NARA.

Internet Research. https://archive.org/

Justia. Supreme Court Center. https://supreme.justia.com/

Mississippi Black Codes. https://chnm.gmu.edu/courses/omalley/120/state/blackcodes.html

National Archives Publications. https://www.archives.gov/publications

National Park Service. The Civil War. Search for Battle Units. https://www.nps.gov/civilwar/search-battle-units.htm

Naval Heritage and Heritage Command. Online Reading Room. https://www.history.navy.mil/research/library/online-reading-room.html

Newspaper Archive. https://access.newspaperarchive.com/

Newspapers. https://www.newspapers.com/newspage/71060069/

Our Documents. National Archives. https://www.ourdocuments.gov

Pew Research Center. https://www.pewresearch.org/

South Texas College of Law Digital Collection. Houston Mutiny and Riot Records. https://cdm16035.contentdm.oclc.org/digital/collection/p15568coll1

The Civil War: Antebellum Period to Reconstruction. Readex. https://infoweb-newsbank com.wvu.idm.oclc.org/iw search/we/MultiSearch?p_product=CivilWar\&p_action=keyword\&p_theme=civilwar\& nbid=K6CM59QUMTYxOTIwMzI2NC40NzkyMTA6MToxNDoxMzIuMTc0LjI1My 2NQ\&p_clear_search=yes\&d_refprod=CivilWar\&

Valley of the Shadow. University of Virginia. http://valley.lib.virginia.edu/VoS/choosepart.html

Virginia Chronicle. Library of Virginia. https://virginiachronicle.com/cgi bin/virginia? $\mathrm{a}=\mathrm{d} \& \mathrm{~d}=\mathrm{SS} 18600821.1 .2$. 
W. E. B. Du Bois Papers. UMassAmherst. https://credo.library.umass.edu/view/full/mums312 b004-i092

\section{Printed Sources:}

"Smoked Yankees" and the Struggle for Empire: Letters from Negro Soldiers, 1898-1902. Edited by William Gatewood. Urbana: University of Illinois Press, 1971.

A Grand Army of Black Men: Letters from African-American Soldiers in the Union Army, 1861 1865. Edited by Edwin S. Redkey. New York: Cambridge University Press, 1992.

Bacon, Edward. Among the Cotton Thieves. Detroit, MI: Free Press, 1867.

Berlin, Ira et. al. Freedom: A Documentary History of Emancipation, 1861-1867, Series II: The Black Military Experience. Cambridge: Cambridge University Press, 1982.

Berlin, Ira et. al., Freedom: A Documentary History of Emancipation, 1861-1867, Series I, Volume II, The Wartime Genesis of Free Labor: The Upper South. Cambridge: Cambridge University Press, 1993.

Berlin, Ira et. al., Ira Berlin, et. al., Freedom: A Documentary History of Emancipation, 1861 1867: Series 1, Volume III: The Wartime Genesis of Free Labor: The Lower South. Cambridge: Cambridge University Press, 1990.

Blackett, R. J. M. Thomas Morris Chester, Black Civil War Correspondent: His Dispatches from the Virginia Front. Baton Rouge: Louisiana State University, 1989.

Brown, William. The Negro in the American Rebellion: His Heroism and His Fidelity. Boston: Lee and Shepard, 1867.

Brownlee, James Henry. War-time Echoes: Patriotic Poems, Heroic and Pathetic, Humorous and Dialectic of the Spanish-American War. Akron, OH: The Werner Company, 1898.

Cozzens, James Gould. A Time of War: Air Force Diaries and Pentagon Memos, 1943-45. Bruccoli Clark, 1984.

Davis, Jr., Benjamin O. American: An Autobiography. Washington, D.C.: Smithsonian Institution Press, 1991.

Delany, Martin R. Blake; or, The Huts of America, 1859-1862. Boston: Beacon Press, 1970.

Dickerson, Donna Lee. The Reconstruction Era: Primary Documents on Events from 1865 to 1877. Greenwood Press, 2003. 
Douglass, Frederick. Narrative of the Life of Frederick Douglass, an American Slave: Written by Himself. Boston: Anti-Slavery Office, No. 25 Cornhill, 1845.

Drew, Thomas. The Refugee or the Narratives of Fugitive Slaves in Canada. Related by Themselves, with an Account of the History and Condition of the Colored Population of Upper Canada. Boston: John P. Jewett and Co., 1856.

Du Bois, W.E.B. The Souls of Black Folk: Essays and Sketches. Chicago: A. C. McClurg and Co., 1903.

Equiano, Olaudah. The Interesting Narrative of the Life of Olaudah Equiano Or Gustavus Vassa, the African, Written by Himself. London: Author, 1794.

Ferris, William H. The Africans Abroad, or His Evolution in Western Civilization Tracing His Development under Caucasian Milieu. New Haven: Tuttle, 1913.

Glenn, Myra C. Jack Tar's Story: The Autobiographies and Memoirs of Sailors in Antebellum America. Cambridge: Cambridge University Press, 2010.

Grant, Ulysses S. Personal Memoirs of Ulysses S. Grant. New York, Charles L. Webster Sc Co., 1885.

Greene, Charles S. Thrilling Stories of the Great Rebellion. Philadelphia: John E. Potter and Co., 1864.

Grimes, William. Life of William Grimes, the Runaway Slave. New York: self-published, 1825.

Hall, James Norman and Charles Bernard Nordhoff, Mutiny on the Bounty. Boston, New York, and London: Little, Brown \& Company, 1932.

Hastie, William H. On Clipped Wings: The Story of Jim Crow in the Army Air Corps. New York: National Association for the Advancement of Colored People, 1943.

I Belong to South Carolina: South Carolina Slave Narratives. Edited by Susana Ashton. Columbia: University of South Carolina Press, 2010.

Lothrop, Charles H. A History of the First Regiment Iowa Cavalry Veteran Volunteers, from Its Organization in 1861 to Its Muster Out of the United States Service in 1866. Lyons, Iowa: Beers and Eaton Printers, 1890.

Mackenzie, Alexander Slidell. Case of the Somers' Mutiny: Defence (sic) of Alexander Slidell Mackenzie, Commander of the U.S. Brig Somers, Before the Court Martial Held at the Navy Yard, Brooklyn. New York: Tribune Office, 160 Nassau Street, 1843.

Marrs, Elijah P. Life and History of the Rev. Elijah P. Marrs, First Pastor of Beargrass Baptist Church, and Author. Louisville, Ky: The Bradley \& Gilbert Company, 1885. 
NAACP. Report of the National Association for the Advancement of Colored People for the Years 1917 and 1918. New York: NAACP National Office, 1919.

Negro Protest Pamphlets: A Compendium: Volume 1. Edited by Dorothy B. Porter. Arno Press, 1969.

Newton, A. H. Out of the briars : an autobiography and sketch of the Twenty-ninth regiment, Connecticut volunteers. Philadelphia: The A.M.E. Book Concern, 1910.

Quarles, Benjamin. Black Abolitionists. New York: Oxford University Press, 1969.

Reports of Cases Relating to Maritime Law: Containing All the Decisions of the Courts of Law and Equity in the United Kingdom, and Selections from the More Important Decisions in the Colonies and the United States: Volume 1. Edited by James A. Petrie. London: H. Cox, 1873.

Rhode Island Soldiers and Sailors Historical Society. Personal Narratives of Events in the War of the Rebellion: Being Papers Read before the Rhode Island Soldiers and Sailors Historical Society. Sixth Series, Nos, 1-10 1903-1905.

Rives, John C. The Congressional Globe: The Thirty-eighth U.S. Congress. Washington: Congressional Globe Office, 1864.

Roe, Frances. Army Letters from an Officer's Wife, 1871-1888. New York: Appleton, 1909.

Senate Committee on Military Affairs. "Affray at Brownsville, Tex," in Summary Discharge or Mustering out of Regiments or Companies. Washington, D.C.: Government Printing Office, 1908.

Senate Documents, Vol. 19, 60 ${ }^{\text {th }}$ Cong., $1^{\text {st }}$ Sess. Washington, D.C.: GPO, 1908.

Smith, John David. We Ask Only For Even-handed Justice: Black Voices from Reconstruction, 1865-1877. Amherst and Boston: University of Massachusetts Press, 2014.

Steward, T. G. The Colored Regulars in the United States Army. Philadelphia: A.M.E. Book Concern, 1904.

The Papers of Ulysses S. Grant: Volume 17: January 1-September 30, 1867. Edited by John Y. Simon. Carbondale and Edwardsville, IL: Southern Illinois University Press, 1991.

The Reminiscences of Major General Zenas R. Bliss, 1854-1876: From the Texas Frontier to the Civil War and Back Again. Edited by Thomas Ty Smith, Jerry Thompson, Robert Wooster, and Ben E. Pingenot. Austin: Texas State Historical Association, 2008. 
U.S. Naval War Records Office. The War of the Rebellion: A Compilation of the Official Records of the Union and Confederate Navies. Washington, D.C.: Government Printing Office, 1894-1922.

U.S. Navy Department. General Regulations for the Navy and Marine Corps of the United States. Washington: J. and G. S. Gideon, 1841.

U.S. Navy Department. Naval Courts and Boards: 1937: With Table of Corresponding Sections 1937 and 1923. Washington, D.C.: Government Printing Office, 1944.

U.S. Navy Department. Naval Documents related to the Quasi War, vol. I. Washington, D.C.: U.S. Government Printing Office, 1935.

U.S. Navy Department. Naval Documents Related to the United States Wars with the Barbary Powers, Vol. 4. Washington, D.C.: Government Printing Office, 1942.

U.S. Navy Department. Regulations for the Government of the Navy of the United States: 1876. Washington, D.C.: Government Printing Office, 1877.

U.S. Navy. Naval Courts and Boards, Section 46, 1937.

U.S. Senate, Committee on Government Operations. Hearings Before the Permanent Subcommittee on Government Operations, United States Senate, $91^{\text {st }}$ Congress, $1^{\text {st }}$ Session, Part 20. Washington, U.S.: Government Printing Office, 1969.

U.S. Senate, Committee on Military Affairs. Affray at Brownsville, Tex.: Hearings. Washington: GPO, 1907.

U.S. Senate, Report of the Proceedings of the Court of Inquiry Relative to the Shooting Affray at Brownsville, Tex., August 13-14, 1906 by Soldiers of Companies B, C, and D Twenty-fifth United States Infantry, Vol. 10, $106^{\text {th }}$ Cong. $3^{\text {rd }}$ Sess. Washington, D.C.: GPO, 1911.

U.S. Senate. Senate Documents, Vol. 23, $60^{\text {th }}$ Cong., $I^{\text {st }}$ Sess. Washington, D.C.: GPO, 1908.

U.S. War Department. Revised United States Army Regulations of 1861. Washington, D.C.: Government Printing Office, 1863.

U.S. War Department. The War of the Rebellion: A Compilation of the Official Records of the Union and Confederate Armies. Washington, D.C.: Government Printing Office, 1880 1902.

Voices of the Buffalo Soldiers: Records, Reports, and Recollections of Military Life and Service in the West. Edited by Frank Schubert. Albuquerque: University of New Mexico Press, 2003.

Winthrop, William. Military Law and Precedents. BeardBooks: Washington, D.C., 1896. 


\section{Secondary Sources}

\section{Books:}

Adams, Kevin. Class and Race in the Frontier Army: Military Life in the West, 1870-1890. Norman: University of Oklahoma Press, 2009.

Alexander, Michelle. The New Jim Crow: Mass Incarceration in the Age of Colorblindness. New York and London: The New Press, 2010.

Ali, Omar H. In the Balance of Power: Independent Black Politics and Third-Party Movements in the United States. Athens: Ohio University Press, 2008.

Astor, Aaron. Rebels on the Border: Civil War, Emancipation, and the Reconstruction of Kentucky and Missouri. Baton Rouge: Louisiana State University Press, 2012.

Astor, Gerald. The Right to Fight: A History of African Americans in the Military (Novato, CA: Presidio Press, 1998.

Baker Farr, James. Black Odyssey: The Seafaring Traditions of Afro-Americans. New York: Peter Lang, 1989.

Barbeau, Arthur E., and Florette Henri. The Unknown Soldiers: African-American Troops in World War I. Philadelphia: Temple University Press, 1974.

Barber, John W. A History of the Amistad Captives. New Haven, Connecticut: E. L. and J. W. Barber, 1840.

Barnickel, Linda. Milliken's Bend: A Civil War Battle in History and Memory. Baton Rouge: Louisiana State University Press, 2013.

Bennett, Michael J. Union Jacks: Yankee Sailors in the Civil War. Chapel Hill: University of North Carolina Press, 2011.

Berlin, Ira. Generations of Captivity: A History of African-American Slaves. Harvard University Press, 2003.

Berlin, Ira. Slaves without Masters: The Free Negro in the Antebellum South. New York: Pantheon Books, 1974.

Berlin, Ira. The Long Emancipation: The Demise of Slavery in the United States. Cambridge and London: Harvard University Press, 2015.

Bernstein, Iver. The New York City Draft Riots: Their Significance for American Society and Politics in the Age of the Civil War. Oxford: Oxford University Press, 1990. 
Berry, Stephen W. All That Makes a Man: Love and Ambition in the Civil War South. Oxford: Oxford University Press, 2003.

Bissland, James. Blood, Tears, and Glory: How Ohioans Won the Civil War. Wilmington, Ohio: Orange Frazer Press, 2007.

Blackmon, Douglas A. Slavery by Another Name: The Re-Enslavement of Black Americans from the Civil War to World War II. New York: Anchor, 2009.

Blair, William. Virginia's Private War: Feeding Body and Soul in the Confederacy, 1861-1865. New York and Oxford: Oxford University Press, 1998.

Blassingame, John W. The Slave Community: Plantation Life in the Antebellum South. New York and Oxford: Oxford University Press, 1972.

Blight, David. Race and Reunion: The Civil War in American Memory. Cambridge: Harvard University Press, 2001.

Bolster, W. Jeffrey. Black Jacks: African American Seamen in the Age of Sail. Cambridge: Harvard University Press, 1997.

Bolzenius, Sandra M. Glory in Their Spirit: How Four Black Women Took on the Army during World War II. Urbana: University of Illinois Press, 2018.

Bowers, William T., William M. Hammond, and George L. MacGarrigle, Black Soldier, White Army: The 24th Infantry Regiment in Korea. Washington, D.C.: U.S. Army Center of Military History, 2014.

Brasher, Glenn D. The Peninsula Campaign and the Necessity of Emancipation: African Americans and the Fight for Freedom. Chapel Hill: University of North Carolina Press, 2014.

Budiansky, Stephen. Perilous Fight: America's Intrepid War with Britain on the High Seas, 1812-1815. New York: Vintage Books, 2012.

Buffalo Soldiers in the West: A Black Soldiers Anthology. Edited by Bruce Glasrud, and Michael Searles. College Station: Texas A\&M University Press, 2007.

Camp, Stephanie. Closer to Freedom: Enslaved Women and Everyday Resistance in the Plantation South. Chapel Hill and London: University of North Carolina Press, 2004.

Carrigan, William D. The Making of a Lynching Culture: Violence and Vigilantism in Central Texas, 1836-1916. Champaign, IL: University of Illinois Press, 2006. 
Carroll, John. The Black Military Experience in the American West. New York: Liveright Publishing, 1971.

Cecelski, David S. The Waterman's Song: Slavery and Freedom in Maritime North Carolina. Chapel Hill and London: University of North Carolina Press, 2001.

Christian, Garna. Black Soldiers in Jim Crow Texas. College Station: Texas A\&M University Press, 1995.

Cohen, William. At Freedom's Edge: Black Mobility and the Southern White Quest for Racial Control, 1861-1875. Baton Rouge: Louisiana State University Press, 1991.

Cohn, Michael, and Michael K.H. Platzer. Black Men of the Sea. New York: Dodd, Mead, 1978.

Cornell, Saul. A Well-Regulated Militia: The Founding Fathers and the Origins of Gun Control in America. New York: Oxford University Press, 2008.

Cornish, Dudley T. The Sable Arm: Black Troops in the Union Army, 1861-1865. Lawrence, Kansas, University Press of Kansas, 1956.

Dalfiume, Richard M. Desegregation of the U.S. Armed Forces: Fighting on Two Fronts, 1939 1953. Columbia, MO: University of Missouri Press, 1969.

Deyle, Steven. Carry Me Back: The Domestic Slave Trade in American Life. Oxford and New York: Oxford University Press, 2005.

Dobak, William A., and Thomas D. Phillips. The Black Regulars, 1866-1898. Norman: University of Oklahoma Press, 2001.

Downs, Greg. Declarations of Dependence: The Long Reconstruction of Popular Politics in the South, 1861-1908. Chapel Hill: University of North Carolina Press, 2014.

Downs, Greg. After Appomattox: Military Occupation and the Ends of War. Cambridge, Mass.: Harvard University Press, 2015.

Downs, Jim. Sick from Freedom: African-American Illness and Suffering During the Civil War and Reconstruction. New York: Oxford University Press, 2012.

Du Bois, W.E.B. Black Reconstruction in America, 1860-1880. New York: The Free Press, 1935.

Fairclough, Adam. Race \& Democracy: The Civil Rights Struggle in Louisiana, 1915-1972. Athens: University of Georgia Press, 2008.

Fitzgerald, Michael W. Urban Emancipation: Popular Politics in Reconstruction Mobile 1860 1890. Baton Rouge: Louisiana State University Press, 2002. 
Fletcher, Marvin. The Black Soldier and Officer in the United States Army, 1891-1917. Columbia: University of Missouri Press, 1974.

Foner, Eric. Nothing But Freedom: Emancipation and Its Legacy. Baton Rouge: Louisiana State University Press, 1983.

Foote, Lorien. The Gentlemen and the Roughs: Violence, Honor, and Manhood in the Union Army. New York and London: New York University Press, 2010.

Fowler, Arlen. The Black Infantry in the West, 1869-1891. Westport: Connecticut: Greenwood Publishing, 1971.

Frankel, Noralee. Freedom's Women: Black Women and Families in Civil War Era Mississippi. Bloomington and Indianapolis: Indiana University Press, 1999.

Franklin, John Hope, and Loren Schweninger. Runaway Slaves: Rebels on the Plantation. New York: Oxford University Press, 1999.

Frederickson, Kari. The Dixiecrat Revolt and the End of the Solid South. Chapel Hill: University of North Carolina Press, 2001.

Gallagher, Gary. The Union War. Cambridge: Harvard University Press, 2011.

Gillett, Mary C. The Army Medical Department 1865-1917. Washington, D.C.: Center of Military History, U.S. Army, 1995.

Gilmore, Glenda. Gender and Jim Crow: Women and the Politics of White Supremacy in North Carolina, 1896-1920 (Chapel Hill: University of North Carolina Press, 1996).

Gourdin, John. Borrowed Identity: $128^{\text {th }}$ United States Colored Troops. Westminster, Maryland: Heritage Book, 2009.

Greene, A. Wilson. The Final Battles of the Petersburg Campaign: Breaking the Backbone of the Rebellion. Knoxville: University of Tennessee Press, 2008.

Gropman, Alan L. The Air Force Integrates. Washington, D.C.: Office of Air Force History, 1985.

Grover, Kathryn. The Fugitive's Gibraltar: Escaping Slaves and Abolitionism in New Bedford, Massachusetts. Amherst: University of Massachusetts Press, 2001.

Gutman, Herbert G. The Black Family in Slavery and Freedom, 1750-1925. New York: Pantheon, 1976. 
Hager, Christopher. Word by Word: Emancipation and the Act of Writing. Cambridge: Harvard University Press, 2013.

Hahn, Steven. A Nation Under Our Feet: Black Political Struggles in the Rural South from Slavery to the Great Migration. Cambridge: Harvard University Press, 2003.

Hannay, David. Naval Courts Martial. Cambridge: Cambridge University Press, 1914.

Hardesty, Von. Black Wings: Courageous Stories of African Americans in Aviation and Space History. New York: HarperCollins, 2008.

Harrison, Robert. Washington during Civil War and Reconstruction: Race and Radicalism. Cambridge: Cambridge University Press, 2011.

Haynes, Robert V. A Night of Violence: The Houston Riot of 1917. Baton Rouge: Louisiana State University Press, 1976.

Horton, James, and Lois Horton. Black Bostonians: Family Life and Community Struggle in the Antebellum North. Holmes \& Meier Publishers, Inc, 2000.

Howard, Victor. Black Liberation in Kentucky: Emancipation and Freedom, 1862-1884. Lexington, Kentucky: University Press of Kentucky, 1983.

Howe, Glenford. Race, War, and Nationalism: A Social History of West Indians in the First World War. Kingston: Ian. Randle Publishers, 2002.

Humphreys, Margaret. Intensely Human: The Health of the Black Soldier in the American Civil War. Baltimore: John Hopkins University Press, 2008.

Hunter, Tera. To 'Joy My Freedom: Southern Black Women's Lives and Labors after the Civil War. Cambridge, Mass. and London: Harvard University Press, 1997.

Jackson, Kellie Carter. Force and Freedom: Black Abolitionists and the Politics of Violence. University of Pennsylvania Press, 2019.

Jaynes, Gerald D. Branches Without Roots: Genesis of the Black Working Class in the American South, 1862-1882. New York: Oxford University Press, 1986.

Johnson, Walter. Soul By Soul: Life Inside the Antebellum Slave Market. Cambridge and London: Harvard University Press, 1999.

Jones, Howard. Mutiny on the Amistad: The Saga of a Slave Revolt and Its Impact on American Abolition, Law, and Diplomacy. Oxford: Oxford University Press, 1987.

Jones, Jacqueline. Labor of Love, Labor of Sorrow: Black Women, Work, and the Family from Slavery to the Present. New York: Basic Books, 1985. 
Glatthaar, Joseph T. Forged in Battle: The Civil War Alliance of Black Soldiers and White Officers. Baton Rouge: Louisiana State University Press, 1990.

Katz, William Loren. The Black West: A Documentary and Pictorial History of the African American Role in the Westward Expansion of the United States. New York: Doubleday, 1971.

Keith, LeeAnna. The Colfax Massacre: The Untold Story of Black Power, White Terror, and the Death of Reconstruction. Oxford: Oxford University Press, 2009.

Kennedy, James. The Great Indian Mutiny of 1857: Its Causes, Features, and Results. London: Ward and Co., 1858.

Kenner, Charles S. Buffalo Soldiers and Officers of the Ninth Cavalry, 1867-1898: Black and White Together. Norman: University of Oklahoma Press, 2014.

Kerr-Ritchie, Jeffrey R. Rebellious Passage: The Creole Revolt and America's Coastal Slave Trade. New York and Cambridge: Cambridge University Press, 2019.

Kimbrough, Natalie. African Americans in the U.S. Military During the Vietnam War. Lanham, Maryland: University Press of America, 2007.

Krüger, C. G., and S. Levsen. War Volunteering in Modern Times: From the French Revolution to the Second World War. New York: Palgrave Macmillan, 2010.

Lane, Ann J. The Brownsville Affair: National Crisis and Black Reaction. Port Washington, New York: Kennikat Press, 1971.

Lang, Andrew. In the Wake of War: Military Occupation, Emancipation, and Civil War America. Baton Rouge: Louisiana State University Press, 2017.

LaRoche, Cheryl Janifer. Free Black Communities and the Underground Railroad: The Geography of Resistance. Champaign, IL: University of Illinois Press, 2013.

Leckie, William, and Sherley Leckie, The Buffalo Soldiers A Narrative of the Black Cavalry in the West. Norman: University of Oklahoma Press, 2003.

Leckie, William. The Buffalo Soldiers: A Narrative of the Negro Cavalry in the West. Norman: University of Oklahoma Press, 1967.

Lee, Ulysses. United States Army in World War II: The Employment of Negro Troops. Washington, D.C.: U.S. Army Center of Military History, 2001.

Leiker, James N. Racial Borders: Black Soldiers Along the Rio Grande. College Station: Texas A\&M University Press, 2009. 
Lepre, George. Fragging: Why U.S. Soldiers Assaulted their Officers in Vietnam. Lubbock: Texas Tech University Press, 2011.

Levine, Kevin. Searching for Black Confederates: The Civil War's Most Persistent Myth. Chapel Hill: University of North Carolina Press, 2019.

Linebaugh, Peter and Marcus Rediker. Many-Headed Hydra: Sailors, Slaves, Commoners, and the Hidden History of the Revolutionary Atlantic. Boston: Beacon Press, 2000.

Litwack, Leon F. F. North of Slavery: The Negro in the Free State. Chicago: University of Chicago Press, 1965.

Lucas, Marion Brunson. A History of Blacks in Kentucky: From Slavery to Segregation, 1760 1891. Frankfurt: Kentucky Historical Society, 2003.

MacGregor, Jr., Morris J. Integration of the Armed Forces, 1940-1965. Washington, D.C.: Center of Military History, 1989.

Maloney, Linda M. The Captain from Connecticut: The Life and Naval Times of Isaac Hull. Boston: Northeastern University Press, 1986.

Manning, Chandra. Troubled Refuge: Struggling for Freedom in the Civil War. New York: Vintage Books, 2016.

Manning, Chandra. What This Cruel War Was Over: Soldiers, Slavery, and the Civil War. New York: Knopf, 2007.

Marshall, Anne E. Creating a Confederate Kentucky: The Lost Cause and Civil War Memory in a Border State. Chapel Hill: University of North Carolina Press, 2010.

Martin, Lori Latrice, et. al. Lessons from the Black Working Class: Foreshadowing America's Economic Health. Santa Barbara, CA: Praeger, 2015.

McConnel, Roland. Negro troops of antebellum Louisiana: a history of the Battalion of Free Men of Color. Baton Rouge: Louisiana State University Press, 1968.

McGinty, Brian. The Rest I Will Kill: William Tillman and the Unforgettable Story of How a Free Black Man Refused to Become a Slave. New York: Liveright, 2016.

McLaurin, Melton A. The Marines of Montford Point: America's First Black Marines. Chapel Hill: University of North Carolina Press, 2009.

McPherson, James. Battle Cry of Freedom: The Civil War Era. New York: Oxford University Press, 1988. 
McPherson, James. Drawn with the Sword: Reflections on the American Civil War. New York: Oxford University Press, 1996.

McPherson, James. Ordeal by Fire: The Civil War and Reconstruction. McGraw-Hill Education, 2010.

Metzgen, Humphrey, and John Graham. Caribbean Wars Untold: A Salute to the British West Indies. Kingston, Jamaica: University of the West Indies Press, 2007.

Miller, Jr., Edward A. Gullah Statesman: Robert Smalls from Slavery to Congress, 1839-1915. Columbia: University of South Carolina Press, 1995.

Mitchell, Reid. The Vacant Chair: The Northern Soldier Leaves Home. Oxford: Oxford University Press, 1988.

Moore III, Cyrus. The Athens Maneuvers: The Ohio National Guard Maneuvers in Athens County, August 17-23, 1904 and the Remaking of the Guard. Athens, Ohio: Athens County Historical Society and Museum, 2012.

Nalty, Bernard C. Long Passage to Korea: Black Sailors and the Integration of the U.S. Navy. Washington, D.C.: Navy Historical Center, 2003.

Nalty, Bernard C. Strength for the Fight: A History of Black Americans in the Military. Free Press, 1986.

Naval Mutinies of the Twentieth Century: An International Perspective. Edited by Christopher M. Bell and Bruce A. Elleman. London and Portland, OR: Frank Cass Publishers, 2003.

Neal, Diane, and Thomas W. Kremm. The Lion of the South: General Thomas C. Hindman. Macon, Georgia: Mercer University Press, 1993.

Nell, William Cooper. The Colored Patriots of the American Revolution. Boston, 1855.

Nelson, Denis D. The Integration of the Negro into the U.S. Navy. New York: Farrar, Straus and Young, 1951.

Newman, Richard S. The Transformation of American Abolitionism: Fighting Slavery in the Early Republic. Chapel Hill: University of North Carolina Press, 2002.

Oshinsky, David M. Worse than Slavery: Parchman Farm and the Ordeal of Jim Crow Justice. New York: Free Press, 1997.

Osur, Alan. Blacks in the Army Air Forces During WWII: The Problems of Race Relations. Honolulu, Hawaii: University Press of the Pacific, 2005. 
Phillips, Christopher. The Rivers Ran Backward: The Civil War and the Remaking of the American Middle Border (New York: Oxford University Press, 2016).

Phillips, Ulrich B. American Negro Slavery. New York: D. Appleton and Co., 1918.

Putney, Martha. Black Sailors: Afro-American Merchant Seamen and Whalemen Prior to the Civil War. New York: Peter Lang, 1989.

Quarles, Benjamin. The Negro in the American Revolution. Chapel Hill: University of North Carolina Press, 2012.

Rachleff, Peter. Black Labor in Richmond, 1865-1890. Urbana and Chicago: University of Illinois Press, 1989.

Rael, Patrick. Eighty-Eight Years: The Long Death of Slavery in the United States, 1777-1865. Athens: University of Georgia Press, 2015.

Ramage, James A., and Andrea S. Watkins, Kentucky Rising: Democracy, Slavery, and Culture from the Early Republic and the Civil War. Lexington, Kentucky: University Press of Kentucky, 2011.

Ramold, Steven J. Baring the Iron Hand: Discipline in the Union Army. DeKalb, IL: Northern Illinois University Press, 2009.

Rebellion, Repression, Reinvention: Mutiny in Comparative Perspective. Edited by Jane Hathaway. Westport, Connecticut: Praeger Publishers, 2001.

Rediker, Marcus. The Amistad Rebellion: An Atlantic Odyssey of Slavery and Freedom. New York: Penguin Books, 2013.

Rediker, Marcus. The Slave Ship: A Human History. New York: Viking Penguin, 2007.

Reid, Richard M. Freedom for Themselves: North Carolina's Black Soldiers in the Civil War Era. Chapel Hill: University of North Carolina Press, 2008.

Rethinking American Emancipation: Legacies of Slavery and the Quest for Black Freedom. Edited by William A. Link and James J. Broomall. Cambridge: Cambridge University Press, 2015.

Richter, William L. The Army in Texas During Reconstruction, 1865-1870. College Station: Texas A\&M University Press, 1987.

Robert W. Mullen, Blacks in America's Wars: The Shift in Attitudes from the Revolutionary War to Vietnam. Pathfinder Press, 1973. 
Rodrigue, John C. Reconstruction in the Cane Fields: From Slavery to Free Labor in Louisiana's Sugar Parishes, 1862-1880. Baton Rouge: Louisiana State University Press, 2001.

Roediger, David. The Wages of Whiteness: Race and the Making of the American Working Class. Verso: 1991.

Sandier, Stanley. Segregated Skies: All-Black Combat Squadrons of WWII. Washington, DC: Smithsonian Institution Press, 1992.

Saville, Julie. The Work of Reconstruction: From Slave to Wage Laborer in South Carolina, 1860-1870. New York and Cambridge: Cambridge University Press, 1994.

Sawrey, Robert D. Dubious Victory: The Reconstruction Debate in Ohio. Lexington: University Press of Kentucky, 2015.

Schama, Simon. Rough Crossings: The Slaves, the British, and the American Revolution. New York: HarperCollins, 2006.

Schneller, Jr., Robert J. Breaking the Color Barrier: The U.S. Naval Academy's First African American Midshipmen and the Struggle for Racial Equality. New York: New York University Press, 2005.

Schubert, Frank N. Outpost of the Sioux Wars: A History of Fort Robinson. Lincoln and London: University of Nebraska Press, 1995.

Schubert, Frank, and Irene Schubert. On the Trail of the Buffalo Soldier: Biographies of African Americans in the U.S. Army, 1866-1917, volume II. Wilmington, Delaware: Scholarly Resources, 2004.

Schwalm, Leslie A. A Hard Fight for We: Women's Transition from Slavery to Freedom in South Carolina. Urbana and Chicago: University of Illinois Press, 1997.

Shaffer, Donald Robert. After the Glory: The Struggles of Black Civil War Veterans. Lawrence: University Press of Kansas, 2004.

Sharp, John G. History of the Washington Navy Yard Civilian Workforce, 1799-1962. Naval District Washington: Washington Navy Yard, 2005.

Sheinkin, Steve. The Port Chicago 50: Disaster, Mutiny, and the Fight for Civil Rights. New York: Roaring Brook Press, 2014.

Sherwood, John Derrell. Black Sailor, White Navy: Racial Unrest in the Fleet during the Vietnam War Era. New York and London: New York University Press. 
Silkenat, David. Driven from Home: North Carolina's Civil War Refugee Crisis. Athens: University of Georgia Press, 2016.

Simpson, Donald George. Under the North Star: Black Communities in Upper Canada Before Confederation. Trenton: Africa World Press, 2005.

Smith, Richard. Jamaican Volunteers in the First World War: Race, Masculinity and the Development of a National Consciousness. Manchester, Manchester University Press, 2004.

Snodgrass, Mary Ellen. Civil Disobedience: An Encyclopedic History of Dissidence in the United States. London and New York: Routledge, 2015.

Stillman II, Richard. Integration of the Negro in the U.S. Armed Forces. Praeger, 1968.

Taylor, Amy Murrell. Embattled Freedom: Journeys through the Civil War's Slave Refugee Camps. Chapel Hill: University of North Carolina Press, 2018.

Trelease, Allen W. White Terror: The Ku Klux Klan Conspiracy and Southern Reconstruction. Harper \& Row, 1971.

Tunnell, Ted. Edge of the Sword: The Ordeal of Carpetbagger Marshall H. Twitchell in the Civil War and Reconstruction. Baton Rouge: Louisiana State University Press, 2000.

Valle, James E. Rocks \& Shoals: Order and Discipline in the Old Navy, 1800-1861. Annapolis: Naval Institute Press, 1980.

Valuska, David. The African American in the Union Navy, 1861-1865. New York: Garland Pub., 1993.

Van de Water, Frederic Franklyn. The Captain Called it Mutiny. New York: Ives Washburn, 1954.

Waldrep, Christopher. Vicksburg's Long Shadow: The Civil War Legacy of Race and Remembrance. New York and Oxford: Rowman \& Littlefield Publishers, Inc., 2005.

Waller, John. Health and Wellness in 19th-Century America. Oxford: Greenwood, 2014.

Weaver, John D. The Brownsville Raid. New York: W. W. Norton and Company, 1970.

Weaver, John D. The Senator and the Sharecropper's Son: Exoneration of the Brownsville Soldiers. College Station, Texas A\&M University Press, 1997.

Webb, Ross A. Kentucky in the Reconstruction Era. Lexington: University Press of Kentucky, 1979. 
Weitz, Mark A. More Damning than Slaughter: Desertion in the Confederate Army. Lincoln: University of Nebraska Press, 2008.

West, Eliot. The Last Indian War: The Nez Perce Story. New York: Oxford University Press, 2009.

Williams, Chad L. Torchbearers of Democracy: African American Soldiers in the World War I Era. Chapel Hill: University of North Carolina Press, 2010.

Williams, David. I Freed Myself: African American Self-Emancipation in the Civil War Era. New York: Cambridge University Press, 2014.

Wilson, Keith P. Campfires of Freedom: The Camp Life of Black Soldiers during the Civil War. Kent and London: The Kent State University Press, 2002.

Wood, Amy Louise. Lynching and Spectacle: Witnessing Racial Violence in America, 1890 1940. Chapel Hill: University of North Carolina Press, 2011.

Young, Jeffrey Robert. Domesticating Slavery: The Master Class in Georgia and South Carolina, 1670-1837. Chapel Hill: University of North Carolina Press, 1999.

Young, R. J. Antebellum Black Activists: Race, Gender, and Self. New York and London: Garland Publishing, 1996.

\section{Articles, Book Chapters, and Dissertations:}

Amato, Sarah. "The White Elephant in London: An Episode of Trickery, Racism, and Advertising." Journal of Social History Vol. 43, No. 1 (Fall 2009): 31-66.

Amron, Andrew D. "Reinforcing Manliness: Black State Militias, the Spanish-American War, and the Image of the African-American Soldier, 1891-1900." The Journal of African American History Vol. 97, No. 4 (Fall 2012): 403-409.

Bender, Robert Patrick. "Fifty-seventh Regiment, United States Colored Troops (US)." http://www.encyclopediaofarkansas.net/encyclopedia/entry detail.aspx?search=1\&entryID=6256.

Bennett, Michael J. "'Frictions': Shipboard Relations between White Sailors and Contraband Sailors during the American Civil War." Civil War History 47 (June 2001): 118-145.

Bolster, W. Jeffry. “'To Feel Like a Man,' Black Seamen in the Northern States, 1800-1860." Journal of American History Vol. 76, No. 4 (Mar., 1990), 1173-1199.

Brown, Russell K. "The Last Civil War Volunteers: The 125th U.S. Colored Infantry in New Mexico, 1866-1867," Army History, No. 92 (Summer 2014): 6-18. 
Bullen, Ross. "Race and the White Elephant War of 1884." The Public Domain Review. October 11, 2017. https://publicdomainreview.org/essay/race-and-the-white-elephant-war-of 1884.

Burran, James A. "Racial Violence in the South During World War II.” Ph.D. dissertation. University of Tennessee, 1977.

Carlson, Paul. "William R. Shafter, Black Troops, and the Opening of the Llano Estacado, 1870 1875." In The African American Experience in Texas, edited by Bruce Glasrud and James Smallwood, 125-137. Lubbock: Texas Tech University Press, 2007.

Cullen, Jim. “'I's a Man Now': Gender and African American Men." In Divided Houses: Gender and the Civil War, edited by Catherine Clinton and Nina Silber, 76-91. Oxford: Oxford University Press, 1992.

Davis, Michael S. “'Many of Them are Among my Best Men': The United States Navy Looks at its African American Crewmen, 1755-1955." PhD Dissertation. Kansas State University, 2001.

Dawley, Alan. "Paths to Power After the Civil War." In Working for Democracy: American Workers from the Revolution to the Present, edited by Paul Buhle and Alan Dawley, 4150. Urbana and Chicago, University of Illinois Press, 1985.

DeLucca, Claire. "Both Sides of the Barbed Wire: Lives of German Prisoners of War and African Americans in Camp Claiborne, Louisiana, 1944-1946.” MA thesis. University of New Orleans, 2018.

Emberton, Carole. "Only Murder Makes Men": Reconsidering the Black Military Experience," The Journal of the Civil War Era Volume 2, Number 3, September 2012, pp. 369-388.

Engs, Robert F. "The Great American Slave Rebellion." Paper delivered to the Civil War Institute at Gettysburg College. 27 June 1991.

Eskow, Nicholas. "Sympathy for the Loss of a Comrade: Black Citizenship and the 1873 Fort Stockton 'Mutiny." UC Berkley: Library, 2018. https://escholarship.org/uc/item/9nf8t9v5.

Evans, Jon. "The Origins of Tallahassee's Racial Disturbance Plan: Segregation, Racial Tensions, and Violence during World War II." Florida Historical Quarterly Vol. 79, No. 3, (2001): 346-364.

Fannin, John F. “The Jacksonville Mutiny of 1865.” Florida Historical Quarterly Vol. 88 (Winter 2010): 368-396.

Fannin, John F. “The Jacksonville Mutiny of 1865.” The Florida Historical Quarterly Vol. 88, No. 3 (Winter 2010): 368-396. 
Foner, Jack. "Blacks in the Post-Civil War Army." In Blacks and the Military in American History: A New Perspective, 52-71. New York: Praeger Publishers, 1974.

Foster, A. Kristen. “'We Are Men!' Frederick Douglass and the Fault Lines of Gendered Citizenship." Journal of the Civil War Era 1, no. 2 (June 2011): 143-175.

Fries, Carsten. "Port Chicago Naval Magazine Explosion: 17 July 1944." Naval History and Heritage Command, July 16, 2019. https://www.history.navy.mil/browse-by-topic/wars conflicts-and-operations/world-war-ii/1944/port-chicago.html.

Furstenberg, Francois. "Beyond Freedom and Slavery: Autonomy, Virtue, and Resistance in Early American Political Discourse.” Journal of American History 89, no. 4 (March 2003): 1295-1330.

Gatti, Sgt. 1st Class Terra C. "Virginia's African American Militiamen: Remembering the $6^{\text {th }}$ Virginia Volunteers." February 20, 2018. https://vaguard.dodlive.mil/2018/02/20/11058/.

Gibbs, C. R. "Blacks in the Union Navy." Negro History Bulletin volume 36, no.6, (1973): 137139.

Goldfield, David. "Segregation and Racism: Taking Up the Dream Again." In Understanding the Little Rock Crisis: An Exercise in Remembrance and Reconciliation, edited by Elizabeth Jacoway and C. Fred Williams. Fayetteville: University of Arkansas Press, 1999.

Goldman, Hal. "Black Citizenship and Military Self-Presentation in Antebellum Massachusetts." Historical Journal of Massachusetts Volume 25, No. 1 (Winter 1997): 158-172.

Goldthree, Reena N. “"A Greater Enterprise than the Panama Canal': Migrant Labor and Military Recruitment in the World War I-Era Circum-Caribbean." Labor: Studies in Working class History of the Americas Volume 13:3-4 (December 2016): 57-82.

Hamer, Philip M. "Great Britain, the United States, and the Negro Seamen Acts, 1822-1848." Journal of Southern History Vol. 1 (February 1935): 3-28.

Harrington, Fred Harvey. "The Fort Jackson Mutiny.” Journal of Negro History 27, no. 4 (October 1942): 420-431.

Harrod, Frederick S. "Jim Crow in the Navy (1798-1941)." United States Naval Institute Proceedings Vol. 105, No. 9 (September 1979): 46-53.

Hill, Norman. "Forging a partnership between blacks and unions." Monthly Labor Review Vol. 110, No. 8 (August 1987): 38-39.

Hine, William C. "Black Organized Labor in Reconstruction Charleston.” Labor History 25, no. 4 (Fall, 1984): 504-517. 
Illingworth, James. "Crescent City Radicals: Black Working People and the Civil War Era in New Orleans.” PhD Dissertation. UC Santa Cruz, 2015.

Jackson, W. Sherman. "Emancipation, Negrophobia and Civil War Politics in Ohio, 1863-1865," The Journal of Negro History Vol. 65, No. 3 (Summer, 1980): 250-260.

Johnson, Alan I. "In Search of Freedom: African Americans and Massachusetts' Militia From 1852-1917.” Master's Thesis. Brandeis University, 2017.

Kaneko, Ayumu. "A Strong Man to Run a Race: W. E. B. DuBois and the Politics of Black Masculinity at the Turn of the Century." The Japanese Journal of American Studies No. 14 (2003): 105-122.

Kantrowitz, Stephen. "Brotherhood Denied: Black Freemasonry and the Limits of Reconstruction." In All Men Are Free and Brethren: Prince Hall and African American Fraternalism, edited by Peter P. Hinks and Stephen Kantrowitz. Ithaca: Cornell University Press, 2013.

Krowl, Michelle A. "For Better or For Worse." In Southern Families at War: Loyalty and Conflict in the Civil War South, edited by Catherine Clinton, 35-48. Oxford: Oxford University Press, 2000.

Lammers, Cornelius J. "Strikes and Mutinies: Comparative Study of Organizational Conflicts between Rulers and Ruled." Administrative Science Quarterly Vol. 14, No. 4. (Dec., 1969): 562-565.

Lammers, Cornelius J. Review of Rebellion, Repression, Reinvention: Mutiny in Comparative Perspective, by Jane Hathaway. International Review of Social History Volume 48, Issue 3 (December 2003).

Logan, Rayford W. "The Negro in the Quasi-War, 1798-1800.” Negro History Bulletin 14 (1951): 128-132.

McGrath, A. Hope. "A Slave in Uncle Sam's Service': Labor and Resistance in the US Army, 1865-1890." Labor: Studies in Working-class History of the Americas Volume 13:3-4 (December 2016): 37-56.

McPherson, James M. "Who Freed the Slaves?" Proceedings of the American Philosophical Society Vol. 139, No. 1 (March 1995): 1-10.

Middleton, Stephen. "The Fugitive Slave Crisis in Cincinnati, 1850-1860: Resistance, Enforcement, and Black, Refugees." The Journal of Negro History Vol. 72, No. 1/2 (Winter - Spring, 1987): 20-32. 
Moneyhon, Carl H. "Thomas Carmichael Hindman (1828-1868)."

http://www.encyclopediaofarkansas.net/encyclopedia/entry-detail.aspx?entryID=1672.

Mormino, Gary R. "Gi Joe Meets Jim Crow: Racial Violence and Reform in World War II Florida." Florida Historical Quarterly Vol. 73, No. 1 (Jul., 1994): 23-42.

Ofari, Earl. "Black Activists and $19^{\text {th }}$ Century Radicalism," The Black Scholar, Vol. 5, No. 5, Black Economics (II) (February 1974): 19-25.

Proctor, Bradley D. “"From the Cradle to the Grave': Jim Williams, Black Manhood, and Militia Activism in Reconstruction South Carolina." American Nineteenth Century History Volume 19, Issue 1 (December 2017): 1-33.

Reidy, Joseph P. "Black Men in Navy Blue During the Civil War." Prologue Magazine. Fall 2001, Vol. 33, No. 3. https://www.archives.gov/publications/prologue/2001/fall/black sailors-1.html.

Samito, Christian G. "The Intersection between Military Justice and Equal Rights: Mutinies, Courts-martial, and Black Civil War Soldiers." Civil War History 53 (June 2007): 170202.

Schoeppner, Michael Alan. "Navigating the Dangerous Atlantic: Racial Quarantines, Black Sailors and United States Constitutionalism." PhD Dissertation. University of Florida, 2010.

Schubert, Frank N. "Buffalo Soldiers: Myths and Realities." Army History (spring 2001): 13-18.

Sheeler, J. Reuben. "The Struggle of the Negro in Ohio for Freedom." The Journal of Negro History Vol. 31, No. 2 (Apr., 1946): 208-226.

Shofner, Jerrell H. "Militant Negro Laborers in Reconstruction Florida." Journal of Southern History Vol. 39, No. 3 (Aug., 1973): 397-408.

Shofner, Jerrell H. “The Pensacola Workingman's Association: A Militant Negro Labor Union during Reconstruction.” Labor History Vol. 13, No. 4 (Fall, 1972): 555-559.

Speidel, Matthias. "A Race That Is Thus Willing To Die For Its Country': African-American Volunteers in the Spanish-American War 1898." In War Volunteering in Modern Times: From the French Revolution to the Second World War, 92-108. Palgrave Macmillan, 2010.

Stafford, Hanford Dozier. "Slavery in a Border City: Louisville, 1790-1860." Ph.D. dissertation. University of Kentucky, 1987.

Stover, Earl F. "Chaplain Henry V Plummer, His Ministry and His Court-Martial.” Nebraska History 56 (1975): 20-50. 
Thaddeus M. Romansky, "Disunion in the Ranks: Soldiers, Citizenship, and Mutiny in the Union Army," PhD dissertation, Texas A\&M University, 2015.

Thompson, Scott. "The Irregular War in Loudoun County, Virginia." In The Guerrilla Hunters: Exploring the Civil War's Irregular Conflicts, edited by Barton A. Myers \& Brian D. McKnight, 123-146. Baton Rouge: Louisiana State University Press, 2017.

Way, Peter. "Memoirs of an Invalid: James Miller and the Making of the British-American Empire in the Seven Years' War." In Rethinking U. S. Labor History: Essays on the Working-Class Experience, 1756-2009, edited by Donna T. Haverty-Stacke and Daniel J. Walkowitz, 25-53. Bloomsbury Academic \& Professional, 2010.

Werrell, Fenneth P. "Mutiny at Army Air Force Station 569: Bamber Bridge, England, June 1943." Aerospace Historian 22 (December 1975): 202-209.

Westwood, Howard C. "The Cause and Consequence of a Union Black Soldier's Mutiny and Execution." Civil War History Volume 31, Number 3, (September 1985): 222-236.

Williams III, Charles Hughes. "'We Have...Kept the Negroes' Goodwill and Sent Them Away': Black Sailors, White Dominion in the New Navy, 1893-1942.” MA Thesis. Texas A\&M University, 2008.

Williams, Chad. "Symbols of Freedom and Defeat: African American Soldiers, White Southerners, and the Christmas Insurrection Scare of 1865.” In Black Flag Over Dixie: Racial Atrocities and Reprisals in the Civil War, edited by Gregory J. W. Urwin, 210 230. Carbondale, IL: Southern Illinois University Press, 2005.

Williams, Clayton W. "A Threatened Mutiny of Soldiers at Fort Stockton in 1873 Resulted in Penitentiary Sentences of Five to Fifteen Years." West Texas Historical Association Year Book Vol: 52, (1976): 78-83.

Wynne, Lewis N. "Brownsville: The Reaction of the Negro Press." Phylon Vol. 33, No. 2 (1972): 153-160. 